$$
\text { UNIVERSIDADE DE SÃO PAULO }
$$

FACULDADE DE FILOSOFIA, LETRAS E CIÊNCIAS HUMANAS DEPARTAMENTO DE LETRAS MODERNAS

PROGRAMA DE PÓS-GRADUAÇÃO EM LÍNGUA E LITERATURA FRANCESA

\author{
LUÍS CLÁUDIO KINKER CALIENDO
}

Orelhas de elefante, olhos de coruja, dentes de javali: maravilhoso e descritivo em Yvain ou le Chevalier au Lion, de Chrétien de Troyes 


\author{
UNIVERSIDADE DE SÃO PAULO \\ FACULDADE DE FILOSOFIA, LETRAS E CIÊNCIAS HUMANAS \\ DEPARTAMENTO DE LETRAS MODERNAS \\ PROGRAMA DE PÓS-GRADUAÇÃO EM LÍNGUA E LITERATURA FRANCESA
}

\title{
Orelhas de elefante, olhos de coruja, dentes de javali: maravilhoso e descritivo em Yvain ou le Chevalier au Lion, de Chrétien de Troyes
}

\author{
Luís Cláudio Kinker Caliendo
}

Dissertação apresentada ao programa de Pós-Graduação em Língua e Literatura Francesa do Departamento de Letras Modernas da Faculdade de Filosofia, Letras e Ciências Humanas da Universidade de São Paulo, para obtenção do título de Mestre em Letras.

Orientadora: Prof ${ }^{a} \operatorname{Dr}^{\mathrm{a}}$ Verónica Galíndez Jorge. 
AUTORIZO A REPRODUÇÃO E DIVULGAÇÃO TOTAL OU PARCIAL DESTE TRABALHO, POR QUALQUER MEIO CONVENCIONAL OU ELETRÔNICO, PARA FINS DE ESTUDO E PESQUISA, DESDE QUE CITADA A FONTE.

Catalogação da Publicação

Faculdade de Filosofia, Letras e Ciências Humanas

Universidade de São Paulo

\section{CALIENDO, Luís Cláudio Kinker}

Orelhas de elefante, olhos de coruja, dentes de javali: maravilhoso e descritivo em Yvain ou le Chevalier au Lion, de Chrétien de Troyes / Luís Cláudio Kinker Caliendo; orientadora Verónica Galíndez Jorge. - São Paulo, 2009.

Dissertação (Mestrado - Programa de Língua e Literatura Francesa) Faculdade de Filosofia, Letras e Ciências Humanas - Universidade de São Paulo.

1. Maravilhoso. 2. Descrição. 3. Descritivo. 4. Poesia medieval. 5. "Literatura" medieval. 6. Chrétien de Troyes. 
CALIENDO, Luís Cláudio Kinker

Orelhas de elefante, olhos de coruja, dentes de javali: maravilhoso e descritivo em Yvain ou le Chevalier au Lion, de Chrétien de Troyes

Dissertação apresentada ao programa de Pós-Graduação em Língua e Literatura Francesa do Departamento de Letras Modernas da Faculdade de Filosofia, Letras e Ciências Humanas da Universidade de São Paulo, para obtenção do título de Mestre em Letras.

Aprovado em:

Banca Examinadora:

Prof. Dr.

Instituição:

Julgamento:

Assinatura:

Prof. Dr.

Instituição:

Julgamento:

Assinatura:

Prof. Dr.

Instituição:

Julgamento:

Assinatura: 
Para tia Mariquita, entusiasta dos estudos, e para minha madrinha, Cleide. Saudade.

Para minha mãe, Maria José, e para Philippe, fontes inesgotáveis de encorajamento. 


\section{AGRADECIMENTOS}

A Verónica Galíndez Jorge, por nos considerar seus filhos e alimentar nossos espíritos com o que há de melhor; por me oferecer um novo olhar sobre a literatura e, consequentemente, um novo mundo; e por uma einsi tres merveilleuse orientação qu'an ne porroit dire de boche.

A Rodrigo Pinto, por ter provocado as primeiras fissuras nas lentes românticas pelas quais eu via a poesia medieval e por ter posto a professora Adma Muhana em meu caminho.

À professora Adma Muhana, por ler atentamente meu relatório de qualificação e por me aconselhar, antes mesmo de estar vinculada formalmente a este trabalho.

Aos professores Jacqueline Cerquiglini-Toulet e Dominique Boutet, por algumas confirmações e uma grande disposição em ajudar um brasileiro aspirante a medievalista.

À professora e amiga Ana Paula Torres Megiani, por ter inserido em minha adolescência a sede de conhecimento.

À professora e amiga Yone de Carvalho, por ter me apresentado Chrétien de Troyes e por ter despertado, juntamente com a professora Dulce Amarante, meu gosto pela Idade Média.

Às amigas Nanci Romero, Flávia Anuatti e Walquíria Cavalari d'Avanzo, que se apressaram a ler Yvain, para podermos trocar ideias.

Aos colegas do GELLE - Grupo de Estudos Literatura, Loucura, Escritura -, pelas discussões. Dentre eles, agradeço a Aline Novais e Lúcia Ribeiro pela leitura e pelos comentários de textos que serviram de base para a elaboração do presente trabalho. Agradeço especialmente a Lívia Cristina Gomes - que, aos vinte e seis anos, já é capaz de ministrar verdadeiras aulas de teoria literária numa conversa informal - e a Luciana Antonini Schoeps — tímida ao vivo, mas realmente uma fera com a caneta na mão —, pela leitura mais que atenta e pelas sugestões para melhorar esta dissertação. 
A Debora Leite David, por conselhos, informações, ajuda com questões burocráticas que me tiram do sério e pelas inúmeras manifestações de amizade.

A minha mãe, Maria José, pela torcida e apoio incondicionais e por ter transformado minha ida às livrarias, quando pequeno, num verdadeiro acontecimento.

A Philippe Juhé, pela revisão dos textos em francês, mas, sobretudo, por me acalmar nos momentos de estresse e por se colocar como anteparo, resguardando-me das pequenas coisas do cotidiano, que roubam um tempo louco à pesquisa.

A meu pai, José, e a meus irmãos Cecília, Helena, Júnior e Sílvia, responsáveis pelo meu gosto por livros e narrativas. A Cecília agradeço ainda por ter sacrificado noites e fins de semana de descanso para empreender uma revisão supercuidadosa deste texto.

A meus sobrinhos Fábio, Eduardo, Ricardo, Mel e Guilherme, e a meu afilhado, André, por compreenderem que, durante a elaboração deste trabalho, nem sempre pude estar tão presente quanto gostaria.

A minha família bleu-blanc-rouge — Émile, Élisa, Valérie, Olivier, Axel e Gabin —, pela torcida enviada diretamente do bocage normand.

Ao amigo Étienne Dabeedin, que não se cansa de querer ajudar.

Aos professores Philippe Willemart e Jerusa Pires Ferreira, pelos comentários sobre meu relatório de qualificação.

Ao CNPq, pela bolsa concedida.

Finalmente, a Edite, Cleide, Romilda e todo o pessoal do DLM, que cuidam muito bem de nós, não nos deixando esquecer datas e documentos importantes. 
“D'ailleurs, ce qu'ils disaient ne m'intéressait pas. Ce que j'écoutais, ce que je guettais, c'était les mots: car j'avais la passion des mots [...]" (Marcel Pagnol)

“[...] la seule merveille, c'est le langage."

(Gérard Genette) 


\section{RESUMO}

CALIENDO, L. C. K. Orelhas de elefante, olhos de coruja, dentes de javali: maravilhoso e descritivo em Yvain ou le Chevalier au Lion, de Chrétien de Troyes. 2009. 154 f. Dissertação (Mestrado) - Faculdade de Filosofia, Letras e Ciências Humanas, Universidade de São Paulo, São Paulo, 2009.

No final do século XII, Chrétien de Troyes - considerado por muitos críticos o maior poeta francês da chamada Idade Média - compõe um poema narrativo - Yvain ou le Chevalier au Lion - no qual se percebem elementos tidos como característicos do gênero maravilhoso, tais quais objetos mágicos e seres extraordinários, como monstros e gigantes. Esses elementos entre outros fatores - levaram boa parte da crítica a enxergar na poesia medieval, durante muito tempo, uma certa ingenuidade, típica de uma "infância da literatura". Rejeitando uma perspectiva evolucionista, o presente trabalho pretende olhar para esse texto antigo respeitando sua alteridade, mas, ao mesmo tempo, trazendo-o para o centro dos debates atuais relativos à literatura. Um olhar atento ao poema permite constatar a íntima relação entre o maravilhoso e o descritivo, a qual constitui o objeto deste estudo. Por meio da leitura do retrato de um camponês monstruoso — tomado em sua textualidade, evitando-se uma separação artificial entre "forma" e "conteúdo" —, promove-se um deslocamento do conceito de maravilhoso, não mais visto como conjunto de motivos, mas como um efeito provocado por operações discursivas.

Palavras-chave: maravilhoso, descritivo, descrição, poesia medieval, "literatura" medieval, Chrétien de Troyes. 


\begin{abstract}
CALIENDO, L. C. K. Elephant ears, owl eyes, boar teeth: marvelous and descriptive in Chrétien de Troyes' Yvain ou le Chevalier au Lion. 2009. 154 f. Masters degree dissertation - Faculty of Philosophy, Letters and Human Sciences, University of São Paulo, São Paulo, Brazil, 2009.

At the end of the twelfth century, Chrétien de Troyes - considered by many critics the greatest French poet of the so-called Middle Ages — produced a narrative poem - Yvain ou le Chevalier au Lion - in which one perceives elements considered characteristic of the genre known as marvelous, such as magical objects and extraordinary beings, like monsters and giants. These elements — among other factors — led much of the criticism to see in medieval poetry, for a long time, some innocence, typical of a "childhood of literature". Rejecting an evolutionary perspective, this study aims at looking at this ancient text respecting its otherness, but at the same time, bringing it to the center of current literature debates. A close look at the poem brings out the intimate relationship between the marvelous and the descriptive, main subject of the present study. Through the reading of the portrait of a monstrous peasant - taken in its textuality, avoiding an artificial separation between "form" and "content" - a shift is promoted in the concept of marvelous, no longer seen as a set of motifs, but as an effect of discursive operations.
\end{abstract}

Key-words: marvelous, descriptive, description, medieval poetry, medieval "literature", Chrétien de Troyes. 


\section{RÉSUMÉ}

CALIENDO, L. C. K. Oreilles d'éléphant, yeux de chouette, dents de sanglier: merveilleux et descriptif dans Yvain ou le Chevalier au Lion, de Chrétien de Troyes. 2009. 154 f. Dissertation niveau Master — Faculté de Philosophie, Lettres et Sciences Humaines, Université de São Paulo, São Paulo, 2009.

À la fin du XII ${ }^{\mathrm{e}}$ siècle, Chrétien de Troyes - considéré par plusieurs critiques comme le plus grand poète français de la période que l'on appelle traditionnellement "le Moyen Âge" compose un poème narratif — Yvain ou le Chevalier au Lion - dans lequel on peut apercevoir des éléments tenus pour caractéristiques du genre merveilleux, tels que des objets magiques et des êtres extraordinaires, comme monstres et géants. Ces éléments - entre autres facteurs - ont amené une bonne partie de la critique à voir dans la poésie médiévale, pendant longtemps, une certaine naïveté, typique d'une "enfance de la littérature". Refusant une perspective évolutionniste, ce travail a pour but de regarder ce texte ancien en respectant son altérité et à la fois en l'apportant au centre des débats actuels concernant la littérature. Un regard attentif sur le poème permet de constater la relation intime entre le merveilleux et le descriptif, laquelle constitue l'objet de cette étude. À partir de la lecture du portrait d'un paysan monstrueux - considéré dans sa textualité, en évitant une séparation artificielle entre "forme" et "contenu" —, on propose un changement du concept de merveilleux, qui ne serait plus envisagé comme un ensemble de motifs, mais comme un effet provoqué par des opérations discursives.

Mots-clés: merveilleux, descriptif, description, poésie médiévale, "littérature" médiévale, Chrétien de Troyes. 


\section{SUMÁRIO}

APRESENTAÇÃ

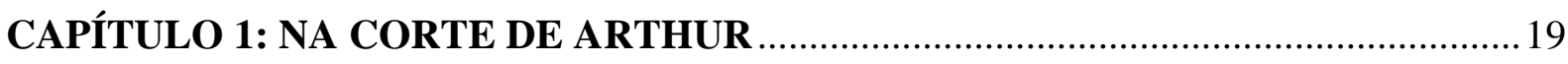

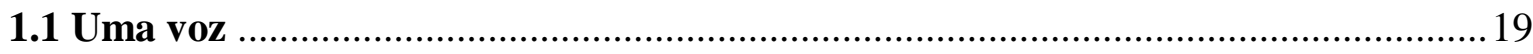

1.2 Escrever com a boca, ler com os ouvidos: literariedade, produção, transmissão e

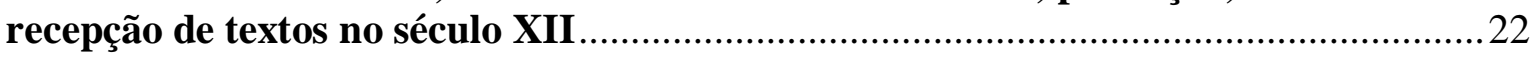

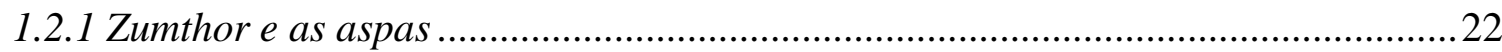

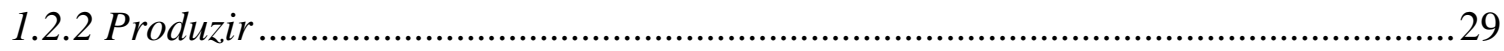

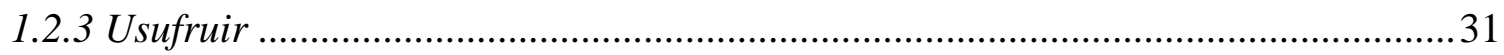

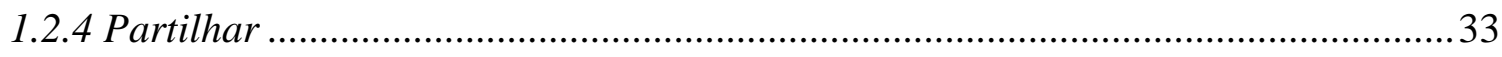

1.3 Pas de songe, ne de fable, ne de mançonge: o nascimento do romance ....................36

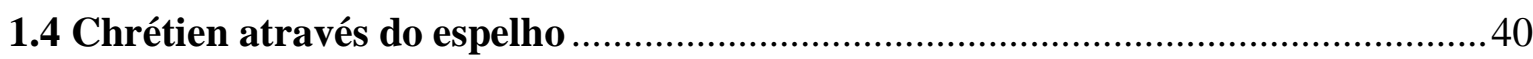

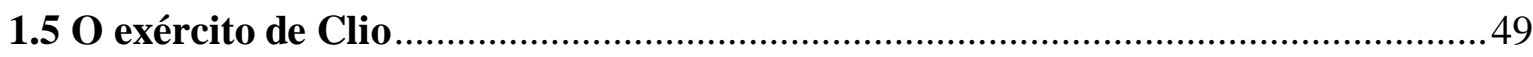

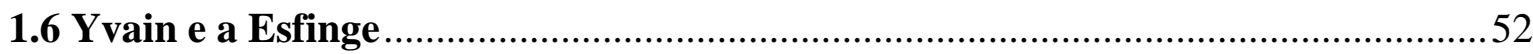

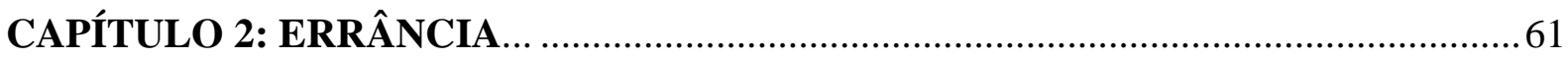

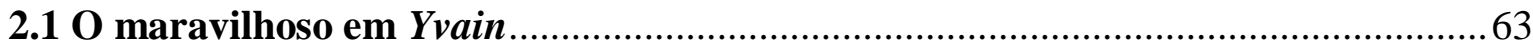

2.1.1 O lugar da maravilha: Yvain e outros textos medievais ......................................65

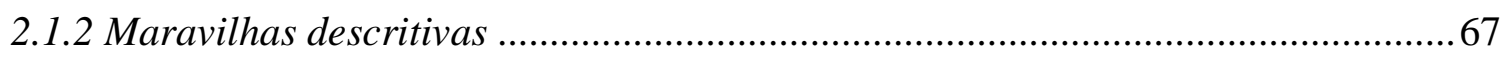

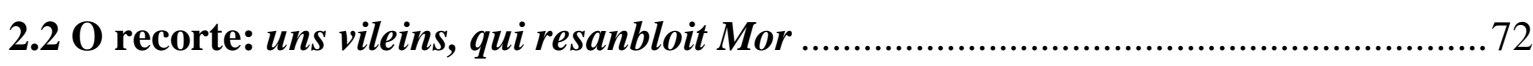

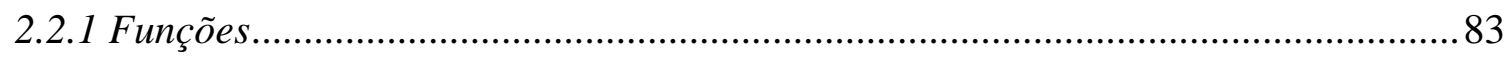

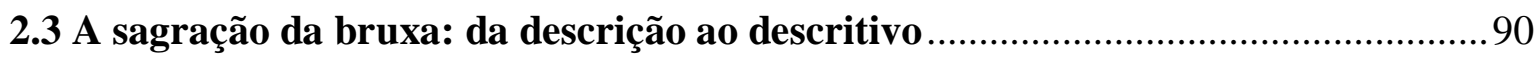

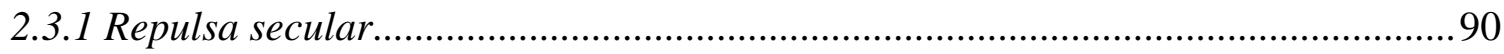

2.3.2 De opositora a auxiliar: funções da descrição ......................................................96

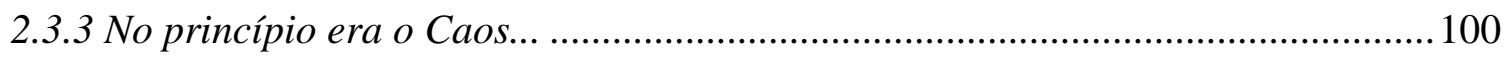

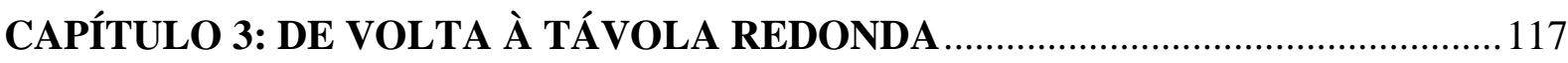

3.1 Ouvir para crer: o maravilhoso dos historiadores ............................................. 117

3.2 O sobrenatural como tema: o maravilhoso da crítica literária ............................ 120

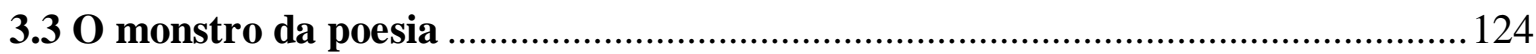

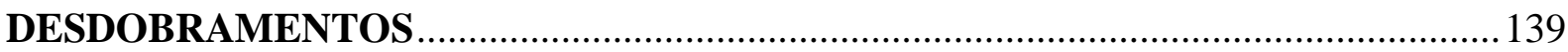

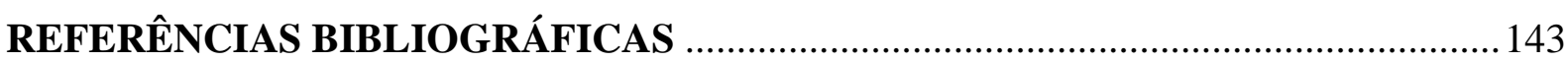




\title{
APRESENTAÇÃO
}

Os estudos sobre a Idade Média no Brasil avançaram bastante nos últimos anos. Mas, embora a Associação Brasileira de Estudos Medievais (ABREM) tenha sido fundada em 1996, e por mais que inúmeros grupos de estudo e de trabalho se dediquem a esse período histórico, muito há por realizar, pois, em certos meios, ainda causa estranhamento o fato de um profissional de ciências humanas brasileiro se dedicar ao medievo, que parece tão distante de nossa realidade. O título do Colóquio Internacional de História Medieval e Ciências Humanas, organizado pelo Laboratório de Estudos Medievais (LEME), realizado em maio de 2008, corrobora a existência dessa sensação, desviando-a, no entanto, do plano espacial para o plano temporal: "Por que estudar a Idade Média no século XXI?".

Na proposta do evento, os organizadores destacam duas tendências: por um lado, a de se apontar a inutilidade dos estudos sobre o período em questão; por outro, a defesa da pertinência de tais estudos, mas sob uma perspectiva utilitarista, fundada na ideia de que, no medievo, encontram-se as raízes do Ocidente contemporâneo. E comentam: "É interessante notar que a ideia de inutilidade dos estudos medievais, bem como sua justificação utilitarista, são concomitantes com a aceleração da uniformização cultural e social do Ocidente desde os anos 1990."1

Inspirando-me no título do evento supracitado, poderia me perguntar: "Por que estudar poesia medieval no Brasil, hoje, na área de Língua e Literatura Francesa da Universidade de São Paulo?". Para fugir à tentação do utilitarismo, responderei simplesmente, parafraseando Italo Calvino: "Porque conhecer a poesia medieval é melhor que não conhecê-la".

Vejamos o belíssimo trecho com que o autor italiano encerra seu artigo "Por que ler os clássicos?":

\begin{abstract}
Agora deveria reescrever todo o artigo, deixando bem claro que os clássicos servem para entender quem somos e aonde chegamos e por isso os italianos são indispensáveis justamente para serem confrontados com os estrangeiros, e os estrangeiros são indispensáveis exatamente para serem confrontados com os italianos.

Depois deveria reescrevê-lo ainda uma vez para que não se pense que os clássicos devem ser lidos porque "servem" para qualquer coisa. A única razão que se pode apresentar é que ler os clássicos é melhor do que não ler os clássicos.
\end{abstract}

\footnotetext{
${ }^{1}$ COLÓQUIO INTERNACIONAL DE HISTÓRIA MEDIEVAL E CIÊNCIAS HUMANAS. "Por que estudar a Idade Média no século XXI?", 2008, São Paulo. Disponível em: 〈http://www.usp.br/leme/coloquio1.html〉. Acesso em: 30 abr. 2008.
} 
E, se alguém objetar que não vale a pena tanto esforço, citarei Cioran (não um clássico, pelo menos por enquanto, mas um pensador contemporâneo que só agora começa a ser traduzido na Itália): "Enquanto era preparada a cicuta, Sócrates estava aprendendo uma ária com a flauta. 'Para que the servirá?', perguntaram-lhe. 'Para aprender esta ária antes de morrer".'2

Da leitura de Calvino, depreende-se que os utilitaristas podem respirar aliviados: literatura, arte, cultura servem, sim, para alguma coisa, algo grande, relacionado ao nosso Ser. No entanto, não é por isso que lemos ou nos interessamos por literatura. A finalidade primeira de toda leitura é a própria leitura. Nesse sentido, não pretendo me estender aqui sobre as teorias que expõem a importância da arte na vida do ser humano. Isso talvez, por si só, rendesse uma dissertação. Limito-me a afirmar que, se conhecer a poesia medieval é melhor que não conhecê-la, é relevante, sim, um estudo dessa natureza aqui, agora, na área de Língua e Literatura Francesa. Pois, nela, a poesia medieval está sendo esquecida. Não apenas não há especialistas em Idade Média no corpo docente da subárea de literatura francesa, como também não há nenhuma disciplina que contemple as obras do período em toda a grade curricular. Alunos de Francês terminam sua graduação sem nunca terem ouvido falar em Chrétien de Troyes, o qual, no entanto, é considerado o primeiro grande romancista francês.

Devo registrar aqui os protestos do professor Philippe Willemart, que, em sua disciplina "Visão diacrônica da literatura francesa", heroicamente concede um espaço a Chrétien. De qualquer forma, ainda é pouco, se considerarmos o total de horas de todas as disciplinas dedicadas à literatura francesa. Além disso, há um rodízio de professores por disciplina e nem todos incluem o século XII em "Visão diacrônica". Isso torna muito circunstanciais as chances de que um aluno - mesmo estudando a literatura francesa por três ou quatro anos - tenha ouvido falar em Chrétien de Troyes.

Devo registrar também o fato de que o próprio professor Willemart orientou recentemente uma tese sobre Christine de Pisan e de que, atualmente, o professor Alain Mouzat orienta uma outra sobre François Villon. Mas é interessante observar que os autores desses trabalhos - Lucimara Leite e Daniel Padilha Pacheco da Costa, respectivamente não são provenientes da graduação em Francês da USP. Ambos são graduados em Filosofia. Ou seja, trata-se de alunos que se interessaram pela poesia medieval fora do curso de Francês, entusiasmaram-se e vieram procurar a área de Língua e Literatura Francesa na qual, ironicamente, o medievo tem pouco ou nenhum espaço. Eu mesmo, embora tenha cursado Letras (Francês/Português) na USP, já havia me deixado fascinar por Chrétien de Troyes em

\footnotetext{
${ }^{2}$ CALVINO, I. Por que ler os clássicos. São Paulo: Companhia das Letras, 2000. p. 16.
} 
minha primeira graduação - História, na PUC-SP — , mas, durante todo do curso de Francês, nunca tive uma única aula sobre Chrétien. Sonho com o dia em que teremos mais dissertações e teses sobre a poesia medieval defendidas aqui, mas, para isso, seria preciso que os professores da casa concedessem a ela mais espaço em suas disciplinas, pois os alunos não podem demonstrar interesse por algo de cuja existência nem desconfiam.

Diante desse quadro, o presente trabalho pretende ser um convite à leitura de autores — bem como de obras anônimas - medievais, através de minha incursão pela escrita de um dos maiores nomes do período - se não o maior - na França. Não tenho a pretensão de descobrir algo absolutamente novo, que tenha escapado ao olhar de tantos críticos franceses e estrangeiros que já se debruçaram sobre a produção de Chrétien de Troyes. Pretendo menos ainda propor uma grande interpretação ou estabelecer a verdade sobre sua obra.

Muito já se escreveu sobre o heroísmo nos romances de cavalaria. Os críticos veem, quase unanimemente, o cavaleiro andante como um ser em busca de si mesmo, da construção de sua identidade. Ele parte só e trilha seu próprio caminho num espaço desconhecido e sobre o qual, por isso mesmo, não exerce nenhum controle. ${ }^{3}$ Ora, não estamos diante de uma metáfora da própria atividade crítica? Passado o tempo da busca pela identificação da verdadeira interpretação da obra, de sua chave de leitura, o que resta ao crítico senão percorrer sozinho essas florestas de papel e, fazendo-o, construir sua própria subjetividade?

É disso que se trata aqui. Como toda leitura só pode ser individual — ainda que leiamos em voz alta para uma plateia, como no caso das performances medievais, a recepção é sempre individual —, o que apresento é um caminho pessoal. A escolha de Chrétien de Troyes como objeto de estudo não se deu por nenhuma inquietação sofisticada sobre um aspecto qualquer da teoria literária. Fui movido, desde o início, por um fascínio diante da obra desse autor. Pouco importa que, no contexto francês, os romances do escritor da Champanha tenham sido já enormemente estudados. Aqui, no curso de Francês da Universidade de São Paulo, a situação é diametralmente oposta. Como podem meus colegas continuar ignorando a existência de um texto que me maravilhou tanto? Não se pode obrigar ninguém a ler uma dada obra, menos ainda a gostar dela. Mas eu, sujeito-leitor, posso expor a todos o prazer estético que sinto ao experimentar uma obra, na esperança de que outros desejem também experimentá-la. Por isso, neste percurso, as paradas propostas não corresponderão aos pontos mais relevantes da obra de Chrétien, mas sim àquilo que me tocou, por uma razão ou por outra, de modo especial em minha errância pelo texto.

\footnotetext{
${ }^{3}$ ZUMTHOR, P. La mesure du monde. Paris: Seuil, 1993. p. 206.
} 
Não nos enganemos, no entanto. O caráter pessoal deste trabalho não significa que minha experiência estética com Chrétien de Troyes e a busca pela construção de minha própria subjetividade como crítico literário sejam algo incomunicável, referente apenas à minha interioridade e não passível de discussão e diálogo. Assim como a aventura individual e única do cavaleiro ganha sentido no relato posterior da própria aventura, minha trajetória só tem sentido na medida em que pode ser partilhada, discutida e criticada. É assim que têm início as aventuras de Yvain: a partir do relato da experiência de outro cavaleiro, Calogrenant. Vamos então a elas, pois é delas que se trata.

Antes, no entanto, pelo fato de Chrétien de Troyes ser ainda tão desconhecido no nosso país, torna-se necessário introduzir o leitor brasileiro no seu universo. Esse é o objetivo do primeiro capítulo. Nele, o leitor é convidado a refletir sobre a própria pertinência do termo "literatura medieval" e a constatar a especificidade do ato de ler e de escrever no século XII. Neste, surge um gênero novo - o romance - , do qual as obras de Chrétien são as grandes representantes em francês até cerca do século XV. Apresento ao leitor o início desse processo e o que se entende então por "romance". Em seguida, mostro que a crítica sobre Chrétien não foi nem unânime nem constante ao longo dos séculos e que hoje o discurso historiográfico predomina entre os medievalistas, o que não deixa de ter consequências para o estudo da poesia. O capítulo se encerra com um panorama da crítica consagrada a Yvain ou le Chevalier au Lion, obra adotada como recorte inicial.

Desse modo, o capítulo primeiro permite ao leitor situar-se não apenas em relação ao contexto de produção e recepção de Chrétien de Troyes, mas também em relação ao olhar que a crítica moderna lança sobre as obras desse autor. Optei por não incluir o tradicional capítulo “pressupostos teóricos", em geral de leitura árida e que, separado do restante, nem sempre permite ao leitor perceber as razões de sua existência. Assim, é possível encontrar ao longo de todo o texto - e já nesse primeiro capítulo - posicionamentos meus em face de questões teóricas, mas imediatamente articulados com o assunto tratado, de modo que o leitor perceba sua motivação.

Deixando um terreno firme - correspondente ao que em geral se considera aceito e estabelecido em relação à produção de Chrétien —, ou seja, afastando-me da segurança do mundo das certezas — ou será justamente nele que reside o perigo? — , proponho ao leitor uma errância por Yvain ou le Chevalier au Lion no segundo capítulo. Nele, baseando-me num conceito inicial de maravilhoso, distingo o modo como este aparece no romance de Chrétien e em outras obras do período, o que me levou a perceber uma relação entre maravilhoso e descritivo. Assim, adoto e apresento um novo recorte que permite estudá-la. Mas, para esse 
estudo, faz-se necessária uma incursão pelos diferentes discursos proferidos sobre a descrição ao longo dos séculos.

O terceiro capítulo traz novamente à cena meu primeiro interesse, que foi o ponto de partida da leitura de Yvain: o maravilhoso. Nesse capítulo, mostro como, de modo geral, os historiadores e críticos literários medievalistas abordam o assunto. Em seguida, a partir de uma nova leitura do recorte, já permeada pelas reflexões do capítulo precedente, proponho uma reformulação da noção de maravilhoso.

Antes de iniciarmos nosso percurso, gostaria de informar o leitor acerca de alguns aspectos formais. Yvain ou le Chevalier au Lion é um romance em verso do século XII, o que significa que foi originalmente composto em francês antigo. Iniciei de forma autônoma meus estudos dessa língua, o que me permitiu não apenas ler o texto original, mas propor aqui uma tradução dos trechos relevantes para minha reflexão. Essa tradução não se pretende poética, tampouco visa a substituir o texto original. Ela se oferece apenas como um facilitador da leitura. Por isso, optei por situar a tradução ao lado do poema, para que o leitor possa compreender cada verso, quase sem retirar os olhos do original. Essa opção, bem como aquela por uma tradução o mais literal possível, fez-se em detrimento da beleza. Pouco importa, já que a tradução aqui é mero apoio para que o leitor possa usufruir a verdadeira beleza, garantida pelas palavras, pelas rimas e pelo ritmo do poema original.

Tomei como texto de referência o volume das obras completas de Chrétien de Troyes organizado por Daniel Poirion para a Bibliothèque de la Pléiade e citado na bibliografia. Trata-se de uma edição bilíngue (francês antigo/francês moderno), para a qual contribuíram diversos especialistas. O estabelecimento do texto de Yvain ou le Chevalier au Lion ficou a cargo de Karl D. Uitti, ao passo que Philippe Walter responde pela tradução, apresentação e notas. Para evitar sobrecarregar as notas de rodapé, limito-me a mencionar o número dos versos citados, já que todos foram retirados dessa edição.

Visto que Chrétien de Troyes é tão pouco conhecido no Brasil e que um dos objetivos deste trabalho é contribuir para sua divulgação, não teria sentido limitar o número de meus possíveis leitores aos conhecedores do francês. Assim, todas as citações de textos críticos nessa língua foram traduzidas - por mim, salvo referência em contrário. Priorizei a leitura do original, colocando-o, a cada ocorrência, no corpo do texto e inserindo as traduções nas notas de rodapé. Nestas, indico apenas os meus grifos, o que significa que, na falta de advertência, trata-se de grifos do autor. Em textos já grifados no original, meus grifos aparecem em negrito, conforme lembrarei em cada citação. 
Cito alguns poucos textos latinos. Pode parecer estranho ao leitor o fato de ver Quintiliano se expressar... em francês! O fato é que, apesar de ter iniciado meus estudos de latim, baseando-me na crença de que o conhecimento da língua e da cultura latinas é indispensável ao bom medievalista, não atingi ainda um nível que me permita a leitura de textos desse porte em sua versão original. Para minimizar o prejuízo, optei por estampar no corpo do trabalho, como nos demais casos, o texto que me serviu como "original", em vez de apresentar apenas minha tradução a partir do francês. Ao menos o leitor terá diante dos olhos o texto que me serviu de base, em vez de depender apenas de uma tradução de segunda mão.

Não utilizo itálico para palavras em francês moderno, pois aparecem em tão grande número que o destaque perderia sua função.

Finalmente, para facilitar a consulta dos títulos constantes da bibliografia, preferi não subdividi-la, como vemos geralmente, em "fontes", "obras de referência", "textos críticos". Assim, o leitor encontrará todas as obras consultadas numa única lista organizada por ordem alfabética. 


\section{CAPÍTULO 1: NA CORTE DE ARTHUR}

\subsection{Uma voz}

Antes de adentrarmos o universo das aventuras de Yvain, conviria, segundo um procedimento tradicional, situar Chrétien de Troyes — sobretudo porque se afirmou na apresentação deste trabalho tratar-se de um autor, no Brasil, bastante desconhecido do público em geral e mesmo de inúmeros especialistas, excetuando-se os medievalistas, evidentemente.

Jean-Charles Payen une-se a outros críticos - que não nomeia, mas insinua constituírem uma maioria - para eleger Chrétien de Troyes "o maior romancista da Idade Média". Mais que isso, Danièle James-Raoul lembra que Jean Frappier, no final dos anos 1960, já considerava o autor de Yvain "um dos grandes nomes da literatura francesa" e que Michel Zink, no início dos anos 1990, referia-se a ele como "um dos maiores escritores franceses". 5

Mas o que sabemos sobre ele? Nada ou quase nada. E esse grande vazio informativo na biografia de Chrétien de Troyes revela-se muito interessante. Será que, depois de textos como "O que é um autor?", de Foucault, ou “A morte do autor”, de Roland Barthes, faz ainda algum sentido a busca desesperada por migalhas a partir das quais reconstituiríamos a vida desse homem do século XII? Não seria mais pertinente tratarmos a marca "Chrétien de Troyes" ${ }^{\prime 6}$ como o autor-modelo proposto por Umberto Eco ${ }^{7}$, ou seja, uma voz que se manifesta como um conjunto de instruções de leitura e que existe apenas dentro do próprio texto, independentemente dos dados biográficos do ser biológico ${ }^{8}$ ? Acredito que sim, e é isso que me leva a não realizar a tradicional apresentação da biografia do escritor. Nada me parece mais descabido que a postura de Philippe Walter em seu pequeno livro sobre Chrétien de Troyes. O professor da Universidade de Grenoble afirma, inicialmente, com muita propriedade: “La tradition médiévale, qui s'intéressait beaucoup plus aux écrits qu'à leurs auteurs, rejoint sur ce point, comme sur plusieurs autres, la critique moderne où l'auteur doit

\footnotetext{
${ }^{4}$ PAYEN, J.-C. Chrétien de Troyes. In: BEAUMARCHAIS, J.-P. de; COUTY, D.; REY, A. Dictionnaire des littératures de langue française. Paris: Bordas, 1984. p. 453.

${ }^{5}$ JAMES-RAOUL, D. Chrétien de Troyes, la griffe d'un style. Paris: Honoré Champion, 2007. p. 11.

${ }^{6}$ Para utilizar a expressão de Danièle James-Raoul, que dá título a seu livro.

${ }^{7}$ ECO, U. Seis passeios pelos bosques da ficção. São Paulo: Companhia das Letras, 2006. p. 21.

${ }^{8}$ O ser biológico é denominado por Eco "autor empírico" (Ibid., p. 17). A essa denominação, muitos críticos preferem simplesmente "escritor", por oposição a "autor", entendido como uma instância construída a posteriori - a partir da circulação do texto — e que emerge da escritura poética, no caso que nos interessa.
} 
s'effacer derrière son oeuvre". ${ }^{9}$ Mas, logo em seguida, contrariando tanto o espírito medieval quanto o espírito moderno, apontados por ele mesmo, elabora todo um capítulo em que busca reconstituir uma possível biografia de Chrétien. Sua leitura pode ser interessante, desde que a consideremos um jogo. Mas como postura teórico-crítica, essa tentativa é absolutamente irrelevante. Ele parece ler a obra para chegar ao escritor. É o que sugerem passagens como esta, em que comenta Perceval ou le conte du Graal:

S'agirait-il d'une ultime référence à la sagesse chrétienne en forme d'héritage spirituel de la part d'un écrivain vieillissant?

Homme de son temps, ayant choisi de s'insérer jusqu'à un certain point dans un de ses courants en mettant son talent au service des grands qui le protègent, Chrétien serait-il devenu pour autant homme de leur monde? Il ne semble pas, si nous savons lire son oeuvre. ${ }^{10}$

Ou ainda esta, na qual, comparando um motivo de Lancelot ou le Chevalier de la Charrette a duas canções de Chrétien, imagina ser possível chegar à interioridade de um homem sobre o qual pouco mais sabemos que o nome: "En traitant et en approfondissant ces problèmes, Chrétien n'obéissait pas seulement à une mode. L'analyse de ses deux poèmes lyriques révèle que le poète vivait en lui-même l'opposition d'Amour et de Raison"11.

Não apenas Walter desconsidera as reflexões modernas sobre a morte do autor ${ }^{12}$, como ignora completamente a distinção, já bastante reconhecida, entre o poeta e o sujeitolírico! É desse tipo de crítica que pretendo me distanciar. ${ }^{13} \mathrm{O}$ único autor que interessa nos limites deste trabalho, o autor-modelo, só pode ser encontrado nos textos.

Se não pretendo abordar a biografia de Chrétien de Troyes, que outras opções me restam para introduzir o leitor brasileiro no seu universo? Uma delas, como se costuma tradicionalmente fazer, consistiria em apresentar um panorama dos eventos políticos e econômicos do momento em que viveu o escritor. No entanto, trata-se de um procedimento

\footnotetext{
${ }^{9}$ WALTER, P. Chrétien de Troyes. Paris: P.U.F., 1997. p. 5: "A tradição medieval, que se interessava muito mais pelos escritos que por seus autores, une-se nesse ponto, como em vários outros, à crítica moderna, na qual o autor deve se apagar atrás de sua obra".

${ }^{10}$ Ibid., p. 16: "Tratar-se-ia de uma última referência à sabedoria cristã em forma de herança espiritual da parte de um escritor em processo de envelhecimento? Homem de seu tempo, tendo escolhido se inserir até certo ponto numa de suas correntes, pondo seu talento a serviço dos grandes que o protegem, Chrétien se teria tornado por isso homem de seu mundo? Não parece, se sabemos ler sua obra".

${ }^{11}$ Ibid., p. 89: "Abordando e aperfeiçoando esses problemas, Chrétien não obedecia apenas a uma moda. A análise de seus dois poemas líricos revela que o poeta vivia nele mesmo a oposição entre Amor e Razão".

${ }^{12}$ QU'EST-CE QU'UN AUTEUR?: COURS D'ANTOINE COMPAGNON, [20-?], Paris. Disponível em:

$<$ http://www.fabula.org/compagnon/auteur2.php>. Acesso em: 30 abr. 2008.

${ }^{13}$ Contudo, apesar de não concordar nem com a abordagem nem com as interpretações das obras de Chrétien propostas nesse livro, devo admitir que ele possui o mérito de apresentar uma visão da obra e do contexto desse escritor para aqueles que, interessados em história literária, não estão ainda familiarizados com a produção medieval. Além disso, seu terceiro capítulo interessa bastante por sua reflexão sobre o nascimento de uma cultura romanesca.
} 
justificável apenas para aqueles convencidos de que haja uma relação de determinação entre o real e o poético, sendo, nessa perspectiva, o segundo apenas um reflexo do primeiro. Ora, a poesia trata não do real, mas do possível, e nada se coaduna menos com o vastíssimo campo das possibilidades poéticas que as relações deterministas. Assim, no quadro deste trabalho, um balanço factual do século XII consistiria num fragmento à deriva, descolado do todo, que se pretende o relato uno do processo de construção de um lugar crítico.

Entretanto, nem toda contextualização se pauta por um determinismo redutor. Assim, visto tratar-se aqui da exposição de um percurso, meu percurso - e, apenas por isso, coerentemente, recuso o plural de modéstia - nada melhor do que começar por oferecer ao leitor brasileiro algo que me ocupou no início da pesquisa: um questionamento sobre a validade do adjetivo "literário" aplicado a textos antigos.

Expressões como "literatura grega", "literatura latina" ou "literatura medieval" provocam a falsa impressão de que a literatura é uma categoria universal e a-histórica. $\mathrm{Na}$ verdade, trata-se de expressões anacrônicas. Se os próprios historiadores reabilitam certo tipo de anacronismo, realçando nele um aspecto intelectualmente saudável ${ }^{14}$, torna-se difícil banir toda e qualquer postura anacrônica em outras áreas. Não condeno o estudioso que, intencionalmente, lança mão do anacronismo, permanecendo atento às armadilhas que tal postura pode pôr em seu caminho. No entanto, parece-me inadmissível o anacronismo realizado por pura ignorância, sem que o pesquisador tenha a mínima consciência de seu procedimento.

Para evitá-lo, antes de abordarmos a narrativa das aventuras de Yvain, reflitamos sobre a existência de uma literatura medieval e sobre a especificidade do ato de ler e de escrever na época de Chrétien.

\footnotetext{
${ }^{14}$ KOBLE, N.; SÉGUY, M. Introduction: "L'audace d'être médiéviste”. Littérature, Paris, n. 148, p. 3-9, déc. 2007. Le Moyen Âge Contemporain: perspectives critiques.
} 


\subsection{Escrever com a boca, ler com os ouvidos: literariedade, produção, transmissão e recepção de textos no século XII}

\subsubsection{Zumthor e as aspas}

A noção de literatura, tal qual a entendemos hoje, surge apenas entre fins do século XVIII e início do século XIX. Foge completamente ao meu propósito introduzir aqui uma discussão sobre as inúmeras definições modernas de literatura. Basta pensarmos no uso corriqueiro da palavra para perceber a diferença entre seus empregos antigo e moderno: ao tecermos um comentário qualquer sobre " $a$ literatura francófona", referimo-nos à totalidade da produção literária da França e dos países de expressão francesa. Na época de Chrétien, o vocábulo latino litteratura não remete a um conjunto de obras. Ele equivale ao termo grammatica, que, por sua vez, pode designar tanto a gramática, tal qual a entendemos, quanto a leitura comentada dos autores e o conhecimento advindo dessa atividade. ${ }^{15}$

Se não consistiam naquilo que, hoje, chamamos de "literatura", em que consistiam então os textos anteriores ao século XVIII?

Do artigo "Retórica e crítica literária na Antiguidade", de Angélica Chiappetta ${ }^{16}$, depreendem-se algumas informações que podem nos ajudar a responder a essa questão. A primeira delas é que muitos desses textos só foram transcritos a posteriori, tendo surgido como "textos orais" ligados a rituais. Assim, embora nos cheguem hoje impressos e encadernados juntos sob o nome de um autor, o contexto e as motivações de sua produção e de sua recepção eram completamente distintos dos nossos. A autora extrai de $A$ invenção da literatura, de Florence Dupont, o exemplo do livro XIII dos Epigramas de Marcial, "recolha de poemas curtos que acompanhavam presentes, as xenia. Foi muito vendido porque os romanos o compravam para dele tirarem dedicatórias poéticas para seus próprios presentes"17. A esse, eu acrescentaria um outro exemplo, cujo benefício consiste em evidenciar a importância da relação entre escritura e oralidade: quem hoje em dia, em sã consciência, diria que conhece a ópera Don Giovanni, de Mozart, sem nunca tê-la visto e ouvido, apenas por ter

\footnotetext{
${ }^{15}$ ZINK, M. Literatura(s). In: LE GOFF, J.; SCHMITT, J.-C. (Coord.). Dicionário temático do Ocidente medieval. São Paulo: EDUSC, 2002. v. 2. p. 79.

${ }^{16}$ CHIAPPETTA, A. Retórica e crítica literária na Antiguidade. Phaos - Revista de Estudos Clássicos, Campinas (SP), n. 1, p. 39-60, 2001. Agradeço a Rodrigo Pinto a indicação desse texto.

${ }^{17}$ Ibid., p. 46.
} 
lido seu libreto $?^{18}$ Isso pareceria risível e, no entanto, fazemo-lo, por exemplo, com relação à lírica trovadoresca e aos lais.

Mesmo num momento posterior, com a cultura do livro já implantada, não haveria correspondência entre textos antigos e a literatura posterior ao século XVIII pelo fato de os monumentos da cultura antiga serem destinados a "profissionais do livro, comentadores, filólogos, professores, poetas, bibliotecários, editores"19 e não ao público em geral.

Mais que a oralidade - afinal poderíamos falar de uma literatura oral —, o que nos impediria de empregar o termo "literatura" para nos referirmos às produções anteriores ao século XVIII seria a forma como são "lidos" os textos antigos ${ }^{20}$.

Jean Rohou, que, curiosamente, defende que o equivalente daquilo que chamamos "literatura" sempre existiu ${ }^{21}$, afirma:

Jusqu'au XVIII ${ }^{\mathrm{e}}$ siècle au moins, le livre est perçu comme l'inscription d'une vérité dont il faut se nourrir, même si la fiction littéraire avait aussi une dimension ludique. C'est encore ainsi que vos grands-parents lisaient La Fontaine, bréviaire de certitudes proverbiales. À partir du XVIII ${ }^{\mathrm{e}}$ siècle, cette soumission respectueuse recule devant une liberté critique. ${ }^{22}$

Paul Zumthor caminha na mesma direção, embora recue dois séculos:

Jusqu'au $\mathrm{XVI}^{\mathrm{e}}$ siècle, la littérature antique, considérée comme l'illustration des arts libéraux, constitue la source principale des sciences naturelles et historiques; on y cherche de plus une leçon de sagesse et de psychologie pratique. On n'est pas insensible à sa beauté, mais c'est d'abord un enseignement qu'on lui demande, comme le fait déjà Macrobe, au $\mathrm{V}^{\mathrm{e}}$ siècle, dans son commentaire de Virgile (Saturnalia), ouvrage dont l'influence fut considérable jusqu'au seuil de l'époque moderne. On poursuit l'usage ancien de collectionner les vers et passages remarquables des auteurs du passé; on constitue ainsi des recueils de sententiae et d'exempla, dans lesquels puisent savants, écrivains, étudiants. ${ }^{23}$

\footnotetext{
${ }^{18}$ DUPONT, F. L'invention de la littérature. Paris: La Découverte, 1998. p. 30.

${ }^{19}$ CHIAPPETTA, A. Retórica e crítica literária na Antiguidade. Phaos - Revista de Estudos Clássicos, Campinas (SP), n. 1, p. 46, 2001.

${ }^{20}$ Chamo de "antigos" não apenas os textos da Antiguidade greco-romana, mas todos aqueles produzidos até meados do século XVIII.

${ }^{21}$ ROHOU, J. L'histoire littéraire. Paris: Nathan, 1996. p. 60.

${ }^{22}$ Ibid., p. 71: "Até pelo menos o século XVIII, o livro é percebido como a inscrição de uma verdade da qual é preciso se nutrir, ainda que a ficção literária tivesse também uma dimensão lúdica. Era ainda assim que seus avós liam La Fontaine, breviário de certezas proverbiais. A partir do século XVIII, essa submissão respeitosa recua diante de uma liberdade crítica". (grifos meus)

${ }^{23}$ ZUMTHOR, P. Histoire littéraire de la France médiévale. Paris: P.U.F., 1954. p. 8: “Até o século XVI, a literatura antiga, considerada como a ilustração das artes liberais, constitui a fonte principal das ciências naturais e históricas; busca-se nela, além disso, uma lição de sabedoria e de psicologia prática. Não se é insensível à sua beleza, mas é primeiramente um ensinamento o que se lhe pede, como já o faz Macróbio, no século V, em seu comentário de Virgílio (Saturnalia), obra cuja influência foi considerável até o limiar da época moderna. Continua-se o uso antigo de colecionar os versos e passagens notáveis dos autores do passado;
} 
Embora os dois autores defendam posições diferentes quanto à existência ou não de uma literatura anterior ao século XVIII, fica clara a concordância de ambos quanto ao fato de esses textos se oferecem antes de tudo como fonte de conhecimentos. O prazer, fruto de sua “dimensão lúdica" ou de sua "beleza", aparece, mas subordinado ao caráter de ensinamento. Temos, aqui, dois dos três elementos mencionados pela Retórica antiga como finalidades do discurso: instruir (docere) e agradar (delectare). ${ }^{24}$ Assim, as citações de dois estudiosos contemporâneos nos remetem a uma disciplina antiga e nos leva a nos perguntarmos se essas não deveriam ser as lentes através das quais nós deveríamos observar os textos medievais, uma vez que, longe ainda de qualquer discurso romântico acerca da ideia de originalidade, foi a Retórica que "reinou absoluta" na Idade Média, só começando a "eclipsar" com o Iluminismo. ${ }^{25}$ Vejamos, então, em que ela consiste.

Segundo Jean-Marie Klinkenberg, a Retórica teria surgido como a "primeira reflexão sistemática sobre os poderes da linguagem". ${ }^{26}$ Em seus primórdios, ela se caracterizava pela valorização do exercício da reflexão pessoal. É o que se encontra em Aristóteles. Sua reformulação rígida e o aprisionamento a cânones revelar-se-iam uma tendência posterior, desenvolvida lentamente. Assim, Retórica e Poética se tornariam preceituários destinados a orientar a produção e a avaliação de obras. Mas essa visão consiste numa distorção do conceito original de Retórica e foi reforçada em manuais do século XIX. ${ }^{27}$

A Retórica está associada à substituição da coerção pela persuasão. O discurso persuasivo age sobre os outros por meio do logos (simultaneamente "palavra" e "razão") e envolve ethos e pathos. O primeiro é o caráter assumido pelo orador, a disposição que os ouvintes lhe conferem, a imagem que ele dá de si mesmo por intermédio de seu discurso. $\mathrm{O}$ ethos não é perene; deve ser constantemente trabalhado. O segundo corresponde aos desejos e emoções do auditório, explorados pelo orador. Dito de outro modo, é a reação desencadeada pelo discurso sobre os ouvintes. ${ }^{28}$

Dois ramos compõem essa disciplina: de um lado, o estudo da produção literária e, de outro, o estudo da produção persuasiva propriamente dita. Se este se baseia nas ideias de

constituem-se, assim, coletâneas de sentenciae e de exempla, dos quais se servem sábios, escritores, estudantes". (grifos meus)

${ }_{24} \mathrm{O}$ terceiro elemento seria o comover (movere).

${ }^{25}$ CHIAPPETTA, A. Retórica e Crítica Literária na Antiguidade. Phaos - Revista de Estudos Clássicos, Campinas (SP), n. 1, p. 40, 2001.

${ }^{26}$ KLINKENBERG, J.-M. Prefácio. In: MOSCA, L. do L. S. (Org.). Retóricas de ontem e de hoje. $2^{\mathrm{a}}$ ed. São Paulo: Humanitas, 2001. p. 11.

${ }^{27}$ MOSCA, L. do L. S. Velhas e novas retóricas: convergências e desdobramentos. In: (Org.). Retóricas de ontem e de hoje. $2^{\text {a }}$ ed. São Paulo: Humanitas, 2001. p. 18. Agradeço a Rodrigo Pinto a indicação desse texto.

${ }^{28}$ Ibid., p. 22. 
respeito à norma e de identidade como alicerces da eficácia do ato comunicativo, aquele se concentra justamente em seus opostos: as ideias de desvio e de diferença, o que inclui inovações e rupturas. ${ }^{29}$

Curtius inicia sua apresentação do sistema da Retórica antiga pela enumeração de suas partes e dos três gêneros do discurso que compõem seu objeto. São estes: o discurso forense (ou judiciário), o deliberativo e o laudatório (ou epidítico). ${ }^{30} \mathrm{O}$ primeiro visa, no combate a um opositor, a destruir argumentos contrários, mediante a apresentação de provas, tanto aquelas criadas pelo discurso quanto aquelas preexistentes a ele. $\mathrm{O}$ segundo trata de questões relacionadas à coletividade, envolvendo problemas administrativos e decisões visando ao bem comum. $^{31}$

Mas, para o filólogo alemão, o gênero epidítico consiste, de longe, no mais importante. Seu objeto é o elogio (e, poderíamos acrescentar, seu contrário, o vitupério), o que explica sua importância política nos tempos da Roma imperial, durante os quais o louvor ao soberano tornou-se um gênero de destaque entre outros, tais como a oração fúnebre, os discursos de aniversário, consolação, saudação, felicitação e o epitalâmio. Exercícios baseados em preceitos sobre o louvor faziam parte da educação latina e, assim, o epidítico marcará bastante a produção poética dos séculos medievais, sobretudo no concernente à descrição ${ }^{32}$, muito empregada, como veremos, na época de Chrétien.

Passemos às cinco partes da Retórica. A primeira delas, a inventio, consiste no “estoque do material, de onde se tiram os argumentos, as provas e outros meios de persuasão relativos ao tema do discurso" ${ }^{33}$. Todo discurso visa a uma causa e, para atingir seu objetivo, lança mão de argumentos dirigidos ao coração ou à razão dos ouvintes. Trata-se dos topoi, que, originariamente, portanto, possuíam uma finalidade prática. Mas, com a perda das liberdades na Grécia e em Roma a partir do fim das cidades-Estado e da República, respectivamente, os discursos judiciário e deliberativo perderam sua razão de ser, sobrevivendo apenas nas escolas. O gênero epidítico, vivo, incorpora os elementos dos demais, mas os topoi se convertem então numa série de clichês dos quais se servirá a poesia dos séculos seguintes ${ }^{34}$, inclusive o de Chrétien e os posteriores a ele.

\footnotetext{
${ }^{29}$ MOSCA, L. do L. S. Velhas e novas retóricas: convergências e desdobramentos. In: (Org.). Retóricas de ontem e de hoje. $2^{\mathrm{a}}$ ed. São Paulo: Humanitas, 2001. p. 23-24.

${ }^{30}$ CURTIUS, E. R. Literatura europeia e Idade Média latina. São Paulo: Edusp, 1996. p. 106-107. Preferirei aqui o termo "epidítico", por me parecer mais frequentemente utilizado.

${ }^{31}$ MOSCA, op. cit., p. 31.

${ }^{32}$ CURTIUS, op. cit., p. 107-108.

${ }^{33}$ MOSCA, op. cit., p. 28.

${ }^{34}$ CURTIUS, op. cit., p. 108-109.
} 
A segunda parte do sistema retórico, a dispositio, refere-se à organização interna do discurso $^{35}$, o qual deve conter: introdução (exordium ou prooemium), por meio da qual se busca a atenção, a docilidade e a benevolência do ouvinte (a captatio benevolentiae, de Cícero); narração (narratio), ou seja, exposição dos fatos, à qual pode se somar uma digressão (a voluptuosa digressio, de Cassiodoro), muito frequente na poesia medieval; argumentação (argumentatio ou probatio); refutação das afirmações do adversário (refutatio); peroração (peroratio ou epilogus), na qual o orador se dirige ao coração dos ouvintes, de modo a despertar neles os afetos desejados. ${ }^{36}$

Segue-se a elocutio, definida por Lausberg como "a expressão linguística dos pensamentos encontrados pela inventio" ${ }^{37}$ Trata-se aqui da escolha e reunião de palavras, dos três gêneros de elocução (humilde, medíocre e grave) e das figuras de retórica, às quais muitos compêndios foram dedicados, tendo em comum o fato de insistirem sobre a necessidade de o discurso ser ornado. Até parte do século XVIII, o ornatus foi a grande aspiração de quem se embrenhava no mundo das letras. ${ }^{38}$ Finalmente, a elocutio concerne às virtudes da correção, da clareza, da concisão, da adequação e da elegância. ${ }^{39}$

A penúltima parte, a actio, consiste na execução do discurso, incluindo o não verbal. Essa atualização do discurso tem como finalidade convencer pelos raciocínios e persuadir com base na emoção. ${ }^{40}$

A quinta e última parte do sistema da Retórica antiga foi acrescentada pelos romanos à herança grega. Trata-se da memoria, ou seja, da "retenção do material a ser transmitido", o que, longe de significar um aprisionamento, garante um melhor domínio do discurso e não elimina a possibilidade de improvisações e de adaptações, diante de eventuais refutações. ${ }^{41}$

Apresentei aqui, de modo bastante esquemático, alguns elementos básicos da Retórica. Ao se ignorar seus princípios, pode-se incorrer em erros graves de interpretação e, disso, Chrétien de Troyes constitui um exemplo. Cada uma de suas obras apresenta seu protagonista como o mais belo, o mais hábil, o mais leal, o mais cortês cavaleiro jamais visto. Ora, essas personagens partilham espaços: por um lado, o espaço ficcional da corte de Arthur; por outro, o espaço material das páginas de um mesmo romance. Assim, elas se encontram constantemente, seja no imaginário dos leitores/ouvintes, seja no espaço físico do livro.

\footnotetext{
${ }^{35}$ MOSCA, L. do L. S. Velhas e novas retóricas: convergências e desdobramentos. In: ontem e de hoje. $2^{\mathrm{a}}$ ed. São Paulo: Humanitas, 2001. p. 28.

${ }^{36}$ CURTIUS, op. cit., p. 108-110.

${ }^{37}$ LAUSBERG, H. Elementos de retórica literária. Lisboa: Fundação Calouste Gulbenkian, [1966]. p. 115.

${ }^{38}$ CURTIUS, E. R. Literatura europeia e Idade Média latina. São Paulo: Edusp, 1996. p. 110.

${ }^{39}$ MOSCA, op. cit., p. 29.

${ }^{40}$ Ibid., p. 29.

${ }^{41}$ Ibid., p. 30.
} (Org.). Retóricas de 
Portanto, poderia causar estranhamento ao leitor desavisado essa aparente contradição: “Afinal, qual o melhor cavaleiro: Lancelot, Gauvain, Yvain, Érec ou Perceval?”, ele se perguntaria. No entanto, ele estaria tomando por contradição o que, na verdade, explica-se pela manifestação do gênero epidítico por meio da amplificatio. $\mathrm{O}$ elogio do protagonista projeta uma figura exemplar que visa à adesão do público, levando-o a identificar-se com a personagem.

O prólogo de Yvain ou le Chevalier au Lion fornece-nos um outro exemplo. Nele, o narrador critica o tempo presente, ao qual se refere como decadente e indigno de ser narrado. Ele se volta então para o passado, digno de elogios e, portanto, de ocupar o centro da narrativa. Nesse ponto, o leitor poderia considerar que Chrétien, como um "espírito aguçado", um "Voltaire medieval", lança sobre sua própria época um olhar corrosivo. Foi assim que muitos historiadores interpretaram Petrarca, quando ele se refere à sua época (século XIV) como tenebrae. Ora, vimos como o elogiar e o censurar consistem na finalidade mesma do gênero epidítico. Assim, tanto Petrarca quanto Chrétien, ao vituperarem seu próprio tempo e destacarem positivamente uma época anterior, não estão fazendo mais que se utilizar de uma tópica antiga, presente já na Ilíada e na Eneida.

Esses dois exemplos mostram como pode ser perigoso desconsiderar a Retórica e tratar textos antigos do mesmo modo como tratamos textos posteriores ao Romantismo, pautados pela noção de originalidade e de autor como gênio criador. Aliás, nossa ideia de autoria nem sempre existiu, tendo-se construído lentamente antes de se fixar, segundo Compagnon, entre o Iluminismo e o Romantismo. Quanto ao período que nos interessa, ele afirma: “La notion d'auteur n'existait ni en Grèce ni au Moyen Âge, où l'autorité émanait des dieux ou de Dieu" "42. É comum os autores medievais escreverem que extraíram seus relatos de um livro. Para não confessarem sua inventividade, muitos autores chegam a citar fontes imaginárias. Segundo Paul Zumthor, nada seria mais estranho para esses autores que nossas ideias de originalidade e propriedade do texto: "Le comble de l'art était pour eux de se référer à une source, spécialement latine ${ }^{, 43}$.

O autor fornece uma explicação para isso, relacionada a duas matrizes culturais: a grega e a judaica. Desprovidos de casta de sacerdotes ou de livro sagrado, os gregos buscavam as bases de sua unidade espiritual nos poetas, sobretudo em Homero (mais tarde,

\footnotetext{
42 “QU'EST-CE QU'UN AUTEUR?”. COURS D’ANTOINE COMPAGNON, [20-?], Paris, 4:Généalogie de l'autorité. Disponível em: < http://www.fabula.org/compagnon/auteur2.php>. Acesso em: 30 abr. 2008: "A noção de autor não existia nem na Grécia nem na Idade Média, em que a autoridade emanava dos deuses ou de Deus".

${ }^{43}$ ZUMTHOR, P. Histoire littéraire de la France médiévale. Paris: P.U.F., 1954. p. 11: "O cúmulo da arte era, para eles, referir-se a uma fonte, especialmente latina".
} 
substituído por Virgílio). Disso decorre que os gregos viam a "literatura" como formadora e como o lugar de concentração do "tesouro da cultura.",44

Para os judeus da época tardia, a Bíblia se identifica com a noção de "escritura". A ideia de santidade do livro, presente no Oriente já no século VII a.C., foi espiritualizada por eles e passou aos cristãos. Isso encontrava e reforçava, no fim da era patrística, a concepção grega. Zumthor afirma: “Avec Prudence (Peristephanon) se constitue, à l'égard de la chose écrite, un sentiment de respect, une volonté de prise au sérieux, qui se perpétueront dorénavant et se traduisent en particulier par un souci constant de recours au texte et à son autorité" 45 .

Segundo o medievalista, o casamento das concepções grega e cristã é responsável por uma ideia que persiste até hoje, mesmo que de modo diferente: "a literatura é conhecimento". ${ }^{46}$ Assim, durante muito tempo, "filosofia" significou o comentário ou a explicação do cânone (bíblico e "literário"). Inversamente, os autores se sentiam imbuídos de uma missão filosófica. Dessa forma, explica-se a moda da alegoria e o hábito de inserir elementos "estéticos" em obras puramente didáticas, como tratados de ciência, por exemplo. Ou seja, "literatura", como entendemos hoje, e conhecimento (científico, histórico, etc.) caminhavam juntos.

Por tudo o que foi dito e por sua insistência sobre a importância da oralidade nas produções do período de Chrétien, Paul Zumthor, a partir do livro que revolucionou a medievalística em 1972, Essai de poétique médiévale ${ }^{47}$, nunca deixou de envolver em aspas o substantivo "literatura" e o adjetivo correspondente ao se referir às obras do período dito "medieval", termo este que, embora também questionasse, não chegou a aprisionar entre sinais tipográficos.

Florence Dupont, diante dos argumentos elencados em seu livro e parcialmente mencionados acima, defende que os textos antigos por ela abordados são ilegíveis literariamente. $^{48}$ Não acredito podermos estender essa afirmação para o conjunto dos textos produzidos anteriormente ao século XVIII e, como vimos, um anacronismo intencional, consciente dos riscos corridos, pode render frutos. No entanto, não pretendo aqui debater essa

\footnotetext{
${ }^{44}$ ZUMTHOR, P. Histoire littéraire de la France médiévale. Paris: P.U.F., 1954. p. 10.

45 Ibid., p. 11: "Com Prudêncio (Peristephanon), constitui-se, em relação à coisa escrita, um sentimento de respeito, uma vontade de levar a sério, que se perpetuarão a partir de então e se traduzem, particularmente, por uma preocupação constante em recorrer ao texto e à sua autoridade".

${ }^{46}$ Ibid., p. 11.

${ }^{47}$ ZUMTHOR, P. Essai de poétique médiévale. Paris: Seuil, 2000.

${ }^{48}$ DUPONT, F. L'invention de la littérature. Paris: La Découverte, 1998. p. 30.
} 
questão, que foge ao propósito geral deste trabalho e ao objetivo primeiro dessa breve apresentação da Retórica, a saber, o de lembrar ao leitor brasileiro não familiarizado com textos antigos a importância de se levar minimamente em conta o contexto de produção desses discursos.

\subsubsection{Produzir}

Como afirma Jerusa Pires Ferreira, Paul Zumthor, com Essai de poétique médiévale, completa o "grande salto teórico [...] rumo às poéticas da voz". ${ }^{9}$ Esboçado em obras anteriores, esse movimento se estenderá em produções posteriores do autor, como Introduction à la poésie orale ${ }^{50}$ e La lettre et la voix ${ }^{51}$, em que a oralidade aparece como traço essencial da poesia medieval.

Apesar disso, Zumthor reconhece a Idade Média também como uma "idade da escritura". ${ }^{52}$ Esse é o aspecto sobre o qual me deterei, já que o presente estudo tem como objeto um romance, gênero nascente sobre o qual o próprio Zumthor afirma: “[...] é forçoso constatar que seu funcionamento só deixa à voz o estatuto de instrumento, subserviente ao texto escrito que ela tem por ofício fazer conhecer, mediante leitura em voz alta" ${ }^{, 53}$.

Basta uma breve consideração das condições materiais de produção da escrita para se perceber que, efetivamente, ao nos debruçarmos sobre um texto do século XII, colocamo-nos diante de uma alteridade.

Zumthor concede todo um capítulo de A letra e a voz a essa questão ${ }^{54}$. Segundo o medievalista, a técnica da escrita era de domínio difícil, o que fazia com que a escritura se mantivesse relacionada à oralidade. Escrevia-se em tabuinhas de cera, posteriormente corrigidas e copiadas em pergaminho. Vários letrados compunham de memória suas obras e ditavam-nas a um escriba, corrigindo, em seguida, as tabuinhas. Os escribas, aparentemente, pronunciavam o que escreviam, ou, quando os autores compunham sem escribas,

\footnotetext{
${ }^{49}$ FERREIRA, J. P. Paul Zumthor, profissão medievalista. Signum, São Paulo, n. 1, p. 185-205, 1999.

${ }^{50}$ ZUMTHOR, P. Introduction à la poésie orale. Paris: Seuil, 1983.

${ }^{51}$ ZUMTHOR, P. A letra e a voz. A "literatura" medieval. São Paulo: Companhia das Letras, 1993.

${ }^{52}$ Ibid., p. 96.

${ }^{53}$ Ibid., p. 265.

${ }^{54}$ ZUMTHOR, P. A escritura. In: A letra e a voz: a "literatura" medieval. São Paulo: Companhia das Letras, 1993. p. 96-116. Salvo indicação em contrário, todas as informações dos tópicos "Produzir" e "Usufruir" foram extraídas dessa obra.
} 
pronunciavam primeiramente seu texto, por partes, para depois, aos poucos, redigirem-nas eles mesmos nas tabuinhas.

As dificuldades da escritura eram de diversas ordens. Em primeiro lugar, escrever consistia num esforço físico, envolvendo várias partes do corpo: dedos, punhos, costas e até a língua, já que tudo era pronunciado. No inverno, os dedos ficavam menos móveis e havia o risco do congelamento da tinta.

Em segundo lugar, os escribas operavam dois sistemas gráficos coexistentes: um, herdado de Roma (alfabeto e abreviações); outro, desenvolvido a partir de cada oficina, como o uso de símbolos específicos, por exemplo.

Um terceiro fator de dificuldade é que a escrita implicava vários processos, todos devendo ser dominados pelo mesmo homem, desde a composição da tinta até o ato de escrever propriamente dito, passando pelo preparo do suporte destinado a receber os caracteres. Lidar com o material era certamente trabalhoso, fosse por sua fragilidade, caso da pena, fosse pela necessidade de um longo processo de preparação, caso do pergaminho.

A essas dificuldades, somava-se uma quarta: a de se dever escrever textos em vernáculo, cuja fonologia tinha exigências próprias, com um alfabeto criado mais de um milênio antes para dar conta do latim arcaico.

Finalmente, não bastava ao escriba o domínio das técnicas gráficas. Ele também se encarregava do que hoje chamaríamos de "estilo", incluindo, entre outras coisas, o domínio das regras discursivas, o conhecimento de fórmulas eficazes e a habilidade na utilização de figuras.

Em virtude de todas essas dificuldades, os escribas se orgulhavam de seu ofício e assinavam, muitas vezes, seus manuscritos, como Guiot o fez com as cópias das obras de Chrétien de Troyes, no início do século XIII.

Percebe-se, assim, o quanto o ato de escrever, no século XII, difere de uma prática, para nós, corriqueira. Diferença constatável sob vários aspectos, mas, sobretudo, pela íntima relação entre escritura e oralidade. 


\subsubsection{Usufruir}

Escrita laboriosa, árdua leitura. Ler não implica apenas um esforço intelectual, mas também físico e, assim, suas dificuldades são, como as do ato de escrever, de ordem vária: o difícil manuseio de inúmeros volumes, a pouca luminosidade, a diversidade dos estilos de escritura e dos sistemas de abreviação, a qualidade do material sobre o qual se escreve, a diferença entre a linguagem dos textos e a fala quotidiana.

Entende-se, assim, que a leitura não consistisse numa atividade comum. Os homens de então não conviviam, como nós, com a onipresença da escrita. Decifrar um texto difícil, até o século XIII, muitas vezes exigia esforços conjuntos de bons leitores.

Na prática, superavam-se os problemas colocados quase que a cada palavra por meio da vocalização. O sentido é em grande parte provocado pelo ritmo. Este sugere, por exemplo, certas palavras cujo início apenas fora decifrado. Sua continuação, antes mesmo da leitura, é deduzida por uma necessidade rítmica. As rimas também desempenham um papel importante nesse processo. ${ }^{55}$

A leitura em voz alta era a regra e as exceções chamavam a atenção. Assim, em suas Confissões, Santo Agostinho não esconde a surpresa em constatar que Santo Ambrósio lia apenas com os olhos.

Estudos citados por Zumthor afirmam que há uma velocidade mínima abaixo da qual a leitura torna-se desinteressante: 4 a 8 palavras por segundo. Um leitor medieval não profissional dificilmente atingia essa meta. E, mesmo entre os profissionais, poucos poderiam se vangloriar de, graças a seu ritmo, manter a atenção de um auditório por um período muito extenso.

A leitura silenciosa tornou-se menos incomum por volta do século XIII e intensificouse nos séculos seguintes, mas, até o século XV, a leitura articulada continuou sendo a regra. O próprio romance, gênero que nos interessa aqui, não nasceu para ser usufruído individualmente pelo leitor em sua intimidade. Apesar de ser o primeiro gênero em francês antigo não destinado ao canto, ele visava a uma leitura em voz alta diante de um refinado público de ouvintes.

Poucos indivíduos eram capazes de ler. A estimativa de $1 \%$ a $2 \%$ da população, por volta do ano 1000, parece otimista a Zumthor! Pertencer à Igreja não garantia aptidão para a

\footnotetext{
${ }^{55}$ ROUSSE, M. Introduction. In: CHRÉTIEN DE TROYES. Yvain ou le Chevalier au Lion. Paris: Flammarion, 1990. p. 16.
} 
leitura: criticou-se periodicamente o analfabetismo do baixo clero. Até o século XIII, a maioria dos nobres era iletrada e, entre eles, as mulheres pareciam dominar mais a leitura que os homens.

O aumento do número de leitores entre os séculos XII e XIV — em razão de objetivos pragmáticos, relacionados a questões de administração e contabilidade e, portanto, desvinculados de qualquer abertura ao poético - não transformou uma realidade estendida até pelo menos o século XIX, ainda que progressivamente atenuada: a grande desproporção entre o número limitado de pessoas aptas a uma leitura fluente e o vasto público visado pela poesia. Isso significa que o fato de não saber ler não exclui a maioria da população das trocas culturais, já que estas se efetivavam por meio da oralidade.

Mas o que e por que se lia? Lia-se para reverenciar a Deus, para se instruir e para se deleitar. Assim, os leitores cercavam-se de textos de devoção, de textos históricos e científicos, e de textos poéticos, embora, como vimos, os limites entre o histórico, o filosófico, o científico e o ficcional pudessem ser bastante tênues.

Não cabe aqui empreender um levantamento exaustivo de todos os tipos de leitura realizáveis na época de Chrétien: a Bíblia, breviários, livros de Horas, bestiários, lapidários, livros de maravilhas, crônicas, romances, etc. Mais condizente com a proposta deste tópico mostrar o quanto o ato de ler e o de escrever na época de Chrétien diferem de nossos hábitos contemporâneos - é lembrar que só a partir do século XIV surge o livro como o conhecemos: textos de um autor reunidos em torno de seu nome. Antes disso, predominava, na composição dos manuscritos, uma aparente despreocupação com a coerência textual e com o que consideramos o acabamento do texto. Assim, raramente um texto é precedido de título ou do nome do autor. Quando mencionadas, essas informações aparecem apenas no explicit. Além disso, fato ainda mais estranho para nós, encontravam-se textos de naturezas diferentes encadernados conjuntamente: um mesmo códice podia conter textos produzidos em diversas datas, com temáticas e funções distintas e até mesmo em diferentes línguas!

Enfim, diante de tantas dificuldades de leitura e de escrita, não surpreende que o livro consistisse num objeto raro e precioso. A quantidade de livros nas bibliotecas era pequena. Um erudito possuía cerca de dez livros, quantidade transportável. Ao longo dos anos, podia aumentar ou apenas modificar sua coleção, por meio de cópias, de trocas e, mais raramente, de compras. Os primeiros indícios de um comércio de livros datam apenas do século XIII, em Paris e Bolonha. 
No entanto, como já foi dito, não se deve imaginar que as pessoas desprovidas do acesso direto aos livros por meio da leitura estivessem privadas do conhecimento veiculado pelos textos, já que este era partilhado pela leitura coletiva em voz alta.

Michel Rousse afirma que, em razão das dificuldades mencionadas, não se poderia ler mais de mil octossílabos em uma hora. Isso significa que a leitura de um romance era dividida em sessões. Ele calcula, para Yvain ou le Chevalier au Lion, dez sessões, compreendendo entre setecentos e oitocentos versos, e propõe uma interessante e original subdivisão da obra, não apenas por seu conteúdo, mas considerando, sobretudo, a capacidade média de atenção por parte de um auditório. ${ }^{56}$ Esta era certamente levada em conta no momento da composição do texto e, provavelmente, o poeta organizava a progressão de seu romance de modo a propiciar a divisão em sessões de leitura. ${ }^{57}$

\subsubsection{Partilhar}

A leitura em voz alta não consistia, no entanto, no único modo de partilhar os textos. Os lais de Marie de France e as canções de gesta, por exemplo, que hoje nos chegam às mãos em formato de livro e que lemos como narrativas literárias, eram veiculados em performances $^{58}$ orais cantadas e com acompanhamento de instrumentos. Não se liam esses textos; eles eram ouvidos e vistos (gestos, roupas, atuação dos instrumentistas, etc.). A teatralidade é uma marca do que hoje chamam "literatura medieval". 59

Zumthor chama de "intérpretes" os "portadores da voz poética", sejam eles leigos ou clérigos, recitadores, cantores ou leitores públicos. ${ }^{60} \mathrm{Sem}$ adentrar as questões relativas ao estatuto de cada um, o que importa aqui é constatar a existência, entre o texto e o leitor, de um intermediário. Nada nos impede de pensar que o retrato de uma criatura monstruosa, tal qual

\footnotetext{
${ }^{56}$ ROUSSE, M. Introduction. In: CHRÉTIEN DE TROYES. Yvain ou le Chevalier au Lion. Paris: Flammarion, 1990. p. 20-21.

${ }_{58}^{57}$ Ibid., p. 22.

${ }^{58}$ É assim que, em suas diversas obras, Zumthor nomeia a simultaneidade da comunicação e da recepção do texto poético. No caso do improviso, entra aí também a esfera da produção. Trata-se, portanto, de uma experiência do texto poético intermediada por uma ou várias vozes num aqui e agora, o que torna cada performance única. Quanto à simples leitura em voz alta, Zumthor considera-a uma "forma atenuada de performance". (ZUMTHOR, P. A letra e a voz: a "literatura" medieval. São Paulo: Companhia das Letras, 1993. p. 23-24.)

${ }^{59}$ ZUMTHOR, P. Essai de poétique médiévale. Paris: Seuil, 2000. p. 52.

${ }^{60}$ ZUMTHOR, P. A letra e a voz: a "literatura" medieval. São Paulo: Companhia das Letras, 1993. p. 56-57.
} 
o vilão de Yvain, conforme veremos adiante, pudesse, conforme a leitura do intérprete (acompanhada de gestos, expressões faciais e marcada por uma entonação específica), assumir aspectos distintos, como o risível e o aterrorizante.

Mas a intermediação não se dá apenas no nível da oralidade. Entre o texto de um autor e o público, ainda que composto por leitores silenciosos, impõe-se a figura do escriba, graças a quem tantas produções antigas puderam ser partilhadas conosco. Um autor poderia ditar um primeiro estado de seu texto a um secretário para depois corrigi-lo e melhorá-lo. Poderia também redigir ele mesmo, diretamente, um rascunho a ser retrabalhado. Mas, lembra-nos Geneviève Hasenohr, qualquer que fosse o método de composição adotado, a produção de um manuscrito considerado "autêntico" e a partir do qual outras cópias seriam fabricadas implicava outra pena que não a do autor, sendo raríssimos os manuscritos autógrafos em francês anteriores ao século XV. ${ }^{61}$

Choca apenas à sensibilidade moderna que o escriba não se limite a seu papel de copista e pareça agir como um editor. Assim, para o profissional da escrita da época de Chrétien, nada mais legítimo que interferir no texto sobre o qual trabalha, podendo tais interferências variar de leves ajustes sem maiores consequências a modificações alterando a interpretação da passagem em questão ou mesmo do conjunto.

Um tipo de modificação comum é aquele que visa a trazer o texto copiado para mais perto do sistema linguístico do escriba e de seu público potencial. Assim, as alterações serão tanto maiores quanto mais distantes no espaço e no tempo forem os sistemas alvo e de origem. $^{62}$

Outro tipo de intervenção, mais agudo, consiste em suprimir passagens inteiras da matriz. Embora, em relação a outros gêneros, as alterações dos romances pareçam mais sutis, o próprio Chrétien de Troyes sofreu, num dos manuscritos de seu Conte du Graal, um corte de cerca de trezentos versos! Tais supressões são geralmente motivadas por uma interpretação pessoal. Assim, noutro manuscrito da mesma obra, um copista preferiu valorizar certos aspectos em detrimento da psicologia amorosa e das descrições do mundo cortês. ${ }^{63}$

Um fenômeno ainda mais complexo consiste em reunir diferentes manuscritos num mesmo códice de modo a ressignificá-los. Não satisfeitos em encadernar sequencial e conjuntamente certo número de manuscritos, muitas vezes, realizavam-se interpolações. Há um volume reunindo, nesta ordem, o Roman de Troie, de Benoît de Sainte-Maure, o Roman

\footnotetext{
${ }^{61}$ HASENOHR, G. Le livre manuscrit. In: LESTRINGANT, F.; ZINK, M. (Dir.). Histoire de la France littéraire. Paris: P.U.F., 2006. v. 1. p. 162.

${ }^{62}$ Ibid., p. 164.

${ }^{63}$ Ibid., p. 166.
} 
d'Énéas, anônimo, e o Roman de Brut, de Wace. Os dois primeiros trazem pela primeira vez em vernáculo os feitos dos heróis da Antiguidade latina. A eles, segue-se o Brut, livre adaptação anglo-normanda da História dos Reis da Bretanha, de Geoffroy de Monmouth, redigida em latim. Tal ordenamento coaduna-se com o desejo de fazer descender diretamente os bretões dos heróis da Antiguidade. O mais interessante é que a crônica de Wace menciona um período de doze anos de paz no reino de Arthur, antes de sua derrocada. No entanto, preocupado com as ações e feitos "históricos" do rei, não desenvolve nada sobre esses anos, limitando-se a mencioná-los como tempos de paz. Ora, chegado o ponto do Brut correspondente a esses anos, o copista simplesmente interrompe a cópia do texto de Wace para acrescentar, nesta ordem, quatro romances de Chrétien: Érec et Énide, Perceval ou le conte du Graal, Cligès e Yvain. Terminado o último verso de Yvain, o escriba retoma o Brut, do ponto onde o havia abandonado. ${ }^{64}$ Esse agenciamento confere novo significado à leitura de Chrétien: sugere que as aventuras de cada cavaleiro se desenvolveram no período de paz do reino de Arthur. Assim, os romances de Chrétien passam a ser vistos não como narrativas míticas independentes que poderiam ter ocorrido num passado remoto e indefinido, mas como elos de uma cadeia, como elementos de uma narrativa escatológica mais ampla.

O mesmo se dá com Robert de Boron. Não apenas seu Merlin, no manuscrito Bodmer 147, passa a integrar um corpus mais amplo ao ser situado como o segundo elemento de uma sequência de quatro obras, como, ele mesmo, é interpolado, recebendo aqui e acolá trechos dos Evangelhos, da Gênese, de um tratado sobre a confissão e outros textos religiosos. ${ }^{65}$

Os elementos considerados por nós "decorativos" também constituem uma maneira de o copista alterar o sentido da obra, já que, para os leitores do período, tais elementos eram altamente significativos: num texto corrido, sem divisões em capítulos, as imagens e as letras ornadas indicam unidades de leitura e reforçam certas passagens, sentidas então como capitais. Assim, mais que decorativos, esses elementos sugerem um modo de ler e uma interpretação. Ora, os escribas nem sempre iluminavam seus manuscritos da mesma forma, o que leva o leitor a perceber o texto de modo diferente segundo o manuscrito que tem sob os olhos. $^{66}$

Tudo isso torna muito pouco operacional o conceito de "autor" para lidar com textos produzidos pelo menos até o século XV. Ainda assim, a marca “Chrétien de Troyes” impôs-se

\footnotetext{
${ }^{64}$ HASENOHR, G. Le livre manuscrit. In: LESTRINGANT, F.; ZINK, M. (Dir.). Histoire de la France littéraire. Paris: P.U.F., 2006. v. 1. p. 166.

${ }^{65}$ Ibid., p. 167.

${ }^{66}$ Ibid., p. 167.
} 
fortemente, não apenas entre os poetas do século XIII ao XV, como referência, mas também entre a crítica medievalística contemporânea, que viu, em suas produções, características que fariam dele o primeiro grande romancista francês.

\subsection{Pas de songe, ne de fable, ne de mançonge: o nascimento do romance}

Ao ver Chrétien de Troyes ser chamado de "primeiro grande romancista francês", o leitor brasileiro não familiarizado com os textos do período provavelmente associará as obras do escritor da Champanha a outras mais marcadamente presentes para ele, tais como as de Balzac ou de Zola. Deve-se logo desfazer essa ideia sob pena de que o leitor se sinta traído em seu pacto de leitura. Assim, vejamos o que se entende por "romance" no século XII.

O termo roman, inicialmente, não se refere a um gênero literário, mas sim à língua vulgar, em oposição ao latim. Narrativas redigidas em latim, herança da Antiguidade, como a Eneida, de Virgílio, ou a Tebaida, de Estácio, circulavam com sucesso entre o público muito restrito que dominava essa língua de cultura. Mas houve quem quisesse colocar esse tesouro antigo à disposição de um público mais vasto e, assim, surgiram as primeiras mises en roman, ou seja, traduções do latim em língua vernácula.

$\mathrm{Na}$ verdade, mais que traduções, esses textos consistiam em adaptações, e, assim, nelas, os heróis gregos e romanos vestem-se, comem e agem como cavaleiros corteses, não num cenário típico da Grécia ou da Roma antigas, mas da França do século XII! As diferenças não se resumem a isso. Há também uma diminuição da presença da mitologia clássica, o que é compensado por um acréscimo de elementos relacionados à magia e à necromancia. Mas, o mais importante, esses romances concedem um lugar novo e importante ao amor. Entretanto, esse elemento ainda é ofuscado pelo desejo expresso de escrever História. Trata-se de fazer remontar aos heróis da Antiguidade a origem da monarquia anglo-normanda. ${ }^{67}$

Tal associação entre romance e História pode nos parecer surpreendente, mas, no século XII, o primeiro termo poderia designar o que apenas para nós constitui gêneros claramente distintos: vidas de santos, obras didáticas, crônicas, narrativas ficcionais e mesmo as canções de gesta. Seu traço em comum? A língua: o romance. ${ }^{68}$

\footnotetext{
${ }^{67}$ STANESCO, M.; ZINK, M. Histoire européenne du roman médiéval. Paris: P.U.F., 1992. p. 26-27.

${ }^{68}$ FRITZ, J.-M. Le roman en vers au Moyen Âge. In: LESTRINGANT, F.; ZINK, M. (Dir.). Histoire de la France littéraire. Paris: P.U.F., 2006. v. 1. p. 958.
} 
Não nos enganemos, entretanto. A recusa do latim resulta de um desejo de difusão, mas não de popularização. Os primeiros romancistas, que escrevem em versos octossílabos com rimas paralelas, dirigem-se a um público aristocrata. Nascido nas cortes, o romance do século XII é dito cortês. ${ }^{69}$

O gênero romance é marcado, portanto, por uma história de transposições: da língua latina à língua românica, do público de clérigos ao público de leigos, e, finalmente, da epopeia a um novo gênero. Embora outros tipos de texto tenham sido traduzidos em língua vulgar, eles não perderam sua essência. Apenas a epopeia, uma vez transposta para a língua dos laicos, transformou-se, como vimos, dando origem a um novo gênero, que passou a ser denominado pela língua empregada nas obras que a ele pertenciam. ${ }^{70}$

A essa primeira geração, surgida em meados do século XII e cujos frutos são conhecidos como "Romances Antigos" ou "Romances de Antiguidade", soma-se, no último terço do século, uma segunda, cujo centro de interesse recai sobre a chamada "matéria da Bretanha”. É onde se inserem os romances de Chrétien de Troyes, compostos entre 1170 e 1185: Érec et Énide (cerca de 1170), Cligès (cerca de 1176), Le Chevalier de la Charrette e Le Chevalier au Lion (que os críticos supõem terem sido elaborados conjuntamente entre 1177 e 1181) e, finalmente, Le conte du Graal (iniciado depois de 1181 e interrompido pela morte do escritor). ${ }^{71}$

Embora os romances bretões se relacionem, sob certos aspectos, com os romances de Antiguidade, trata-se verdadeiramente de uma nova etapa. Chrétien de Troyes, assim como seu "rival" Gautier d'Arras e os autores de dois Tristan, Thomas e Béroul, situa-se num momento de "autonomização" do romance ${ }^{72}$. O termo pode parecer exagerado, se pensarmos que os limites entre os gêneros muitas vezes são tênues. O sucesso do romance fará com que a canção de gesta incorpore muitas de suas características, tornando-se diferente do modelo da Canção de Rolando, por exemplo. Além disso, distinguir o discurso histórico do poético, em textos desse período, não constitui tarefa fácil. Diante disso, como falar em autonomia? Mesmo com toda a dificuldade mencionada, o fato é que, a partir desses autores, o romance não pode mais ser definido com relação a um pré-texto latino a ser vulgarizado, mas sim em contraste com outros gêneros do período.

\footnotetext{
${ }^{69}$ FRITZ, J.-M. Le roman en vers au Moyen Âge. In: LESTRINGANT, F.; ZINK, M. (Dir.). Histoire de la France littéraire. Paris: P.U.F., 2006. v. 1. p. 959-960.

${ }^{70}$ Ibid., p. 960.

${ }^{71}$ DELCOURT, T. La littérature arthurienne. Paris: P.U.F., 2000. p. 15.

${ }^{72}$ FRITZ, op. cit., p. 961.
} 
Vejamos o que a crítica medievalista afirma, de modo geral, sobre as obras de Chrétien.

Diferentemente de Wace em parte de seu Roman de Brut - uma adaptação, como já dito, da Historia Regum Britanniae, de Geoffroy de Monmouth —, Chrétien não se propõe a narrar cronologicamente os eventos marcantes do reinado de Arthur, o qual funciona apenas como pano de fundo. Não mais no papel de herói, o rei assume uma postura passiva como simples regulador da justiça, deixando a cena livre para as ações de seus cavaleiros, cujas aventuras implicam não apenas os feitos de armas, mas uma busca amorosa.

Logo no início de Le Chevalier au Lion, Calogrenant, um dos cavaleiros de Arthur, prestes a narrar um episódio ocorrido consigo há sete anos, pede atenção a seus ouvintes, pois o que contará a seguir não se trata de sonho, nem de fábula, nem de mentira (Car ne vuel pas parler de songe, / Ne de fable, ne de mançonge $)^{73}$. Como entender essa reivindicação de veracidade diante de um relato repleto de maravilhas como uma fonte cuja água, embora fervente, mantém-se mais fria que o mármore?

A afirmação de seu caráter verídico é um lugar-comum das narrativas do período. Chrétien, sem romper com o topos, introduz uma variação ao deslocá-lo do discurso do narrador para a fala de uma personagem, que, momentaneamente, assume ela mesma o papel de narrador. Isso parece aumentar o distanciamento de Chrétien em relação a uma noção de verdade empírica. Estamos definitivamente nos domínios do ficcional; a única verdade possível é a da poesia.

Qual é essa verdade? Para Michel Zink, a verdade do sentido: ao se voltar para o mundo arturiano, "tema de história mas também tema para histórias que todos escutam e nas quais ninguém acredita", o romance não pode mais "reivindicar a verdade dos fatos. Procura, então, a do sentido. É a grande mudança realizada por Chrétien de Troyes". ${ }^{74}$

O sen - vocábulo em francês antigo empregado pelos medievalistas para designar uma suposta significação profunda da obra — não se confunde com o sentido literal, mas também não é autônomo como aquele da narrativa alegórica: ele é imanente. O texto não é mero pretexto para um sentido exterior a ele. ${ }^{75}$ Basicamente, o sen gira em torno de duas esferas distintas, mas não antagônicas, que o cavaleiro deve aprender a conciliar: as armas e o amor. Ambos constituintes da noção de aventura, que envolve ainda a descoberta do

\footnotetext{
${ }^{73}$ Versos 171-172.

74 ZINK, M. Literatura(s). In: LE GOFF, J.; SCHMITT, J.-C. (Coord.). Dicionário temático do Ocidente medieval. São Paulo: EDUSC, 2002. v. 2. p. 85.

${ }^{75}$ STANESCO, M.; ZINK, M. Histoire européenne du roman médiéval. Paris: P.U.F., 1992. p. 36.
} 
desconhecido, estranho e inquietante. ${ }^{76}$ Essa descoberta se dá, evidentemente, fora dos domínios de Arthur e implica, portanto, a noção de errância, que, segundo Zumthor, difere da acepção do verbo errer em francês moderno: 'L'errance, c'est donc le fait de cheminer sur la terre hors de ses bornes les mieux connues, dans un espace sur lequel, pour cela même, on ne possède aucune maîtrise" 77 . Assim, "errância" não significa, nesse contexto, caminhar sem objetivo, o que esvaziaria a própria noção de um sentido profundo. Ao contrário, nos séculos XII e XIII, “l’errance revêt généralement l'aspect d'une 'quête', lançant le chevalier sur la piste incertaine d'un être ou d'un objet désiré" ${ }^{, 78}$.

O sen, como nos lembra Frappier, não possui o rigor de uma tese ${ }^{79}$ e deve ser antes compreendido como uma lição, um ensinamento ${ }^{80}$, tão característicos desses romances compostos do século XII ao XVI para a recreação e a edificação da nobreza ${ }^{81}$. No caso de Chrétien, o sen é garantido pela conjointure, termo utilizado pelo poeta (e por mais ninguém em nenhum outro texto!) no prólogo de Érec et Énide, para designar sua arte da composição, por oposição à prática dos jograis profissionais que, segundo ele, despedaçam e corrompem os textos que recitam. Assim, contrariando as tópicas de modéstia, Chrétien, no primeiro de seus romances que chegaram até nós, já se vangloria de seu modo de tratar sua matéria. Se ele não a cria ex nihilo (e quem, antigo ou moderno, o faz?), ele a ordena com mestria, agenciando os episódios de modo a formar um todo coerente e coeso. ${ }^{82}$

Portanto, os romances de Chrétien parecem ser mais que uma fabula, termo latino empregado pela retórica medieval para designar narrativas ficcionais visando ao puro divertimento. Assim, embora o autor de Yvain não reivindique a veracidade factual de sua

\footnotetext{
${ }^{76}$ A noção de aventura é riquíssima e detalhá-la aqui foge ao escopo deste trabalho. Danièle James-Raoul propõe um estudo bastante aprofundado do tema no terceiro capítulo de sua obra: JAMES-RAOUL, D. Chrétien de Troyes, la griffe d'un style. Paris: Honoré Champion, 2007. Menos interessante, mas tratando da noção de aventura especificamente em Le Chevalier au Lion, temos: MARACHE, B. Le mot et la notion d'aventure dans la "conjointure" et le "sen" du Chevalier au Lion. In: DUFOURNET, J. (Org.). Le Chevalier au Lion: approches d'un chef-d'oeuvre. Paris: Champion, 1988. p. 119-138.

${ }^{77}$ ZUMTHOR, P. La mesure du monde. Paris: Seuil, 1993. p. 206: "A errância é, pois, o fato de caminhar sobre a terra fora de seus limites mais bem conhecidos, num espaço sobre o qual, por isso mesmo, não se possui nenhum domínio".

${ }^{78}$ Ibid., p. 206-207: "a errância assume geralmente o aspecto de uma 'busca', lançando o cavaleiro na pista incerta de um ser ou de um objeto desejado".

${ }^{79}$ FRAPPIER, J. Étude sur Yvain ou le Chevalier au Lion de Chrétien de Troyes. Paris: SEDES, 1969. p. 193.

${ }^{80}$ STANESCO, M.; ZINK, M. Histoire européenne du roman médiéval. Paris: P.U.F., 1992. p. 36.

${ }^{81}$ ZUMTHOR, op. cit., p. 201. Per Nykrog também menciona o caráter edificante dos romances de Chrétien: "Ce n'était pas l'éducation de la comtesse Marie ni du comte Philippe qu'il s'agissait de faire, c'était celle des 'jeunes' qui s'unissaient dans leurs cours, dont ils se considéraient comme les mentors, et qu'ils se sentaient appelés à former." (NYKROG, P. Chrétien de Troyes: romancier discutable. Genève: Droz, 1996. p. 48: "Não era a condessa Marie nem o conde Philippe que se tratava de educar, mas os 'jovens' que se uniam em suas cortes, dos quais eles se consideravam mentores e os quais eles se sentiam chamados a formar".)

${ }^{82}$ Danièle James-Raoul analisa estilisticamente a conjointure de Chrétien no quarto capítulo da obra: JAMESRAOUL, D. Chrétien de Troyes, la griffe d'un style. Paris: Honoré Champion, 2007.
} 
narrativa, não podemos deixar de ver uma correspondência entre o Chrétien que enaltece sua conjointure garantidora de um sen e a personagem Calogrenant que recusa a denominação de fable para seu relato.

No entanto, os frutos dessa arte da composição, da qual Chrétien parecia tanto se orgulhar e que é hoje unanimemente reconhecida pela crítica, não chegaram incólumes até nós. Na verdade, a partir de certo momento, foram enterrados e precisaram ser redescobertos, como veremos a seguir.

\subsection{Chrétien através do espelho}

O quase total desconhecimento de Chrétien de Troyes no Brasil surpreende menos se levarmos em conta que, na própria França, sua redescoberta é relativamente recente. Ao contrário do que se poderia imaginar, seu nome não descreveu ao longo dos séculos uma trajetória ininterrupta e de constante valorização. Per Nykrog empreende um interessantíssimo balanço do modo como diferentes leitores de diferentes períodos (des)consideraram o poeta da Champanha. ${ }^{83}$

Verdadeira referência para os poetas que o sucederam, Chrétien teve seus romances em verso reproduzidos por copistas até pelo menos a metade do século XIV, apesar do sucesso dos romances em prosa a partir do século XIII. Entre os séculos XVI e XIX, no entanto, excetuando-se breves reaparições, o poeta não é mais mencionado nos círculos considerados "sérios".

O debate entre Gaston Paris e Wendelin Förster, no último quarto do século XIX, retirou Chrétien das sombras. Gaston Paris enterrou definitivamente a ideia de que os romances em prosa lhe tivessem servido de modelo, inaugurando assim o pensamento que perdura até hoje de que o século XIII é que passou a prosificar romances em verso. Mas Gaston Paris, como os folcloristas românticos e pós-românticos, preocupava-se com o problema das fontes e via nos textos conhecidos simples reflexos de modelos de uma tradição

\footnotetext{
${ }^{83}$ Nykrog realiza um trabalho detalhado, explicitando a posição de vários críticos de um mesmo período. Não caberia fazer o mesmo nos limites desta introdução. Assim, atenho-me ao que me parece essencial e, aos interessados, sugiro a leitura do primeiro capítulo do livro do crítico dinamarquês: NYKROG, P. Chrétien chez les médiévistes. In: _. Chrétien de Troyes: romancier discutable. Genève: Droz, 1996. p. 7-40. Como praticamente todo o conteúdo deste tópico é extraído desse capítulo, evitarei o excesso de notas, citando apenas os demais textos utilizados, salvo em caso de citação direta do texto de Nykrog.
} 
popular mais rica. Já Förster distinguia grande originalidade em Chrétien, que teria composto livremente não apenas a partir de uma tradição oral popular, mas também de outros romances, organizando tudo em torno de uma ideia geral. ${ }^{84}$

Apesar das divergências, ambos os críticos acusavam Chrétien de infringir os princípios garantidores de uma boa execução do romance. No entanto, o ideal que tinham em mente era o do romance realista, o que, evidentemente, não representava uma aspiração para um escritor do século XII.

Assim, o século XX se inicia com uma imagem negativa de Chrétien, herdada do século anterior: "un écrivailleur mondain, charmant mais superficiel, facile et irresponsable, qui a abîmé les belles légendes dont il faisait des amusettes pour ses nobles patrons" ${ }^{\text {}}$.

Essa imagem negativa fez com que Chrétien ficasse novamente soterrado por seus sucessores, já que os medievalistas da primeira metade do século XX pareciam se interessar pela lenda arturiana como um todo, sobretudo pelas histórias do Graal. Ora, sabemos que, nos romances de Chrétien, a figura do rei se retrai, deixando o primeiro plano livre para as aventuras de seus cavaleiros, narradas não como parte da história de Arthur, mas como trajetórias individuais e independentes. Quanto ao Graal, ele figura apenas no último de seus romances, Perceval ou le conte du Graal, interrompido por sua morte.

“Jamais depuis le XIII' siècle la 'matière de Bretagne' n'avait obsédé autant d'esprits que dans la première moitié du XX ${ }^{\mathrm{e}}$, , afirma Nykrog. ${ }^{86}$ No entanto, a preocupação continuava sendo as fontes, vistas, desta vez, como a possibilidade de explicação do Graal. Assim, de modo geral, os críticos não fixaram sua atenção sobre os textos de que dispunham, incluindo os de Chrétien, mas voltaram seu olhar para além deles, na tentativa de encontrar a chave do mistério num passado nebuloso.

Poderíamos agrupar a maioria desses pesquisadores em duas correntes: uma se debruçando sobre a tradição cristã; outra, sobre a tradição bretã, de fundo celta. Alguns nadavam contra a corrente, como Edmond Faral, que, em 1913, publica uma coletânea de artigos sobre as fontes latinas dos romances e contos ditos "corteses".

\footnotetext{
${ }^{84}$ O que levará Förster, mais tarde, a falar mesmo em "romance de tese", ideia retomada por Gustave Cohen e refutada posteriormente por Jean Frappier. (COHEN, G. Un grand romancier d'amour et d'aventure au XII siècle: Chrétien de Troyes et son oeuvre. Paris: Boivins \& Cie., 1931. p. 158; FRAPPIER, J. Étude sur Yvain ou le Chevalier au Lion de Chrétien de Troyes. Paris: SEDES, 1969. p. 17 e 186.)

85 NYKROG, P. Chrétien de Troyes: romancier discutable. Genève: Droz, 1996. p. 18: "um escrevinhador mundano, encantador mas superficial, fácil e irresponsável, que estragou as belas lendas das quais fazia brinquedos para seus nobres patrões".

${ }^{86}$ Ibid., p. 19: “Jamais, desde o século XIII, a 'matéria da Bretanha' obsidiara tantos espíritos quanto na primeira metade do século XX".
} 
Entretanto, algumas ousadas vozes discordantes manifestaram seu desejo de ler os romances, em vez de buscar suas fontes. Assim, Myrhha Borodine publica em 1909 um estudo no qual investiga a mulher e o amor no século XII a partir dos romances de Chrétien. A estudiosa russa admira Chrétien e vê nele um dos primeiros, se não o primeiro, criador do romance psicológico da Europa moderna.

No início dos anos 1930, Gustave Cohen publica Un grand romancier d'amour et d'aventure au XII siècle: Chrétien de Troyes et son oeuvre, que, apesar de consistir numa obra de vulgarização, trazia no título sua originalidade: romper com a ideia reinante de que não teria havido um grande romance de amor anterior a La princesse de Clèves.

Em 1915, William Nitze já chamara a atenção sobre os termos sen, matiere e conjointure como reveladores de uma preocupação de Chrétien como técnico do romance e, em 1936, Wilhem Kellermann, inspirando-se parcialmente nas artes poéticas dos séculos XII e XIII publicadas por Faral em 1924, estuda a arte de Chrétien em Perceval. Em seu estudo, já não há mais a condescendência, presente em outros trabalhos, em relação a um escritor medieval, marcado por uma suposta ingenuidade típica da "infância da literatura francesa".

Nykrog considera Le sens de l'aventure et de l'amour (Chrétien de Troyes), de Reto Bezzola, publicado em 1947, “o primeiro estudo plenamente moderno sobre Chrétien". ${ }^{87}$ Nele, o autor considera os romances de Chrétien verdadeiras obras de arte e propõe que sejam vistas em sua forma, única capaz de revelar um sentido profundo.

Assim, Chrétien começa a sair dos escombros sob os quais o século XIX o enterrara e, dessa vez, ressurge como escritor sem igual, não apenas mestre de uma técnica de composição que o teria feito reinar em seu tempo, mas também pensador, cuja sutileza e profundidade começava agora a ser percebida pelos não medievalistas.

Os anos 1950 se abrem, assim, com uma nova perspectiva para os estudos sobre Chrétien. Alguns marcos dessa nova situação são a criação da Sociedade Internacional Arturiana e as publicações dos romances de Chrétien por Mario Roques. O que caracteriza esse novo período é o fim dos grandes debates, prevalecendo uma atmosfera de consenso. Há abordagens diferentes evidentemente, umas mais próximas do existencialismo, outras mais afinadas com o espírito do New Criticism e suas close readings, por exemplo. Mas predomina o ecumenismo e não o confronto de teses absolutamente antagônicas. Os estudos de Jean Frappier foram, segundo Nykrog, os grandes responsáveis por essa solidificação da imagem de Chrétien como um grande nome da literatura francesa. Mas a aceitação de seus romances

\footnotetext{
${ }^{87}$ NYKROG, P. Chrétien de Troyes: romancier discutable. Genève: Droz, 1996. p. 23.
} 
não se deve unicamente ao esforço de medievalistas. O teatro do absurdo e o nouveau roman, ainda que mal compreendidos nos anos 1950, foram rapidamente difundidos dentro e fora da França, a ponto de provocar uma mudança de sensibilidade: já não se podia mais ler e escrever como antes.

Assim, fica evidente que o desprezo de muitos por Chrétien até os anos 1940 se devia à inadequação de sua escritura ao modelo realista do século XIX. A partir do momento em que a postura iconoclasta se instaura e que a ordem do dia é enterrar o século XIX com seu positivismo, Chrétien ressurge como um autor com o qual é mais fácil se identificar. A escritura do autor de Yvain, que repelira os antigos leitores, é justamente o fator de atração do novo público constituído após os anos 1970 e 1980, que beberam em outras fontes que não o realismo. O depoimento de Nykrog sobre seus alunos é exemplar:

Les étudiants avec qui je le lis aujourd'hui, nés vers 1970 et nourris dès l'enfance de la littérature qui les avait entourés (psychologique comme chez Butor, mythique comme chez Tolkien, ambiguë comme chez Borgès, futuriste comme dans la "science-fiction", ou, assez souvent, tout cela à la fois, même dans les bandes dessinées), se sentent à l'aise avec un roman de Chrétien, comme sur un terrain familier. Ils sont abasourdis quand je leur raconte qu'au temps de mes vingt-cinq ans, il était loin d'en être ainsi. ${ }^{88}$

Mas a tranquilidade do período de Frappier escondia sinais de que algo estava para explodir, o que de fato aconteceu a partir dos anos 1970. Há estudos mostrando que, em duas décadas, publicou-se sobre literatura medieval tanto ou mais que em dois séculos! Seria possível uma visão consensual entre tantos estudos?

Não se trata, no entanto, de uma questão meramente quantitativa, mas, sobretudo, de um salto qualitativo ${ }^{89}$, relacionado a uma renovação dos estudos literários em geral e não apenas medievalísticos. Em 1963, Roland Barthes publica um ensaio no qual opõe à crítica universitária (leia-se "positivista") uma outra, muito heterogênea, mas que tem como traço unificador o fato de seus representantes se filiarem a uma das grandes ideologias do momento, o que o leva a denominá-la crítica ideológica. ${ }^{90}$ Não se trata mais, portanto, da situação em

\footnotetext{
${ }^{88}$ NYKROG, P. Chrétien de Troyes: romancier discutable. Genève: Droz, 1996. p. 27: "Os estudantes com quem o leio hoje, nascidos por volta de 1970 e nutridos desde a infância com a literatura que os circundara (psicológica como em Butor, mítica como em Tolkien, ambígua como em Borges, futurista como na 'ficção científica', ou, com bastante frequência, tudo isso ao mesmo tempo, até nas histórias em quadrinhos), sentem-se à vontade com um romance de Chrétien, como num terreno familiar. Eles ficam aturdidos quando lhes conto que, aos meus vinte e cinco anos, estava longe de ser assim".

${ }^{89}$ Até aqui, limitei-me a apresentar o panorama realizado por Nykrog. A partir de agora, começo a me distanciar desse autor, por divergir do modo como trata a crítica dos anos 1970. A expressão "salto" é minha. Nykrog não concordaria com essa ideia, como veremos em seguida.

${ }^{90}$ BARTHES, R. Les deux critiques. In :___. Essais critiques. Paris: Seuil, 1964. p. 255-260.
} 
que vários pesquisadores somam esforços para, guiados por um único método, atingir uma verdade. Aliás, em outro ensaio do mesmo ano, Barthes nega que a verdade constitua o objetivo da crítica. ${ }^{91}$

Esse tipo de discurso dá margem a confusões que perduram. Sente-se um tom nostálgico no comentário de Nykrog de que, se não há mais verdade, não há mais por que brigar, já que cada um pode extrair dos textos o que bem entende. ${ }^{92}$ Trata-se, evidentemente, de um reducionismo. Mesmo os opositores de Barthes hão de concordar que a complexidade de seu pensamento ultrapassa em muito o simplismo de afirmar que se possa dizer qualquer coisa sobre qualquer texto. Além disso, há sim elementos para um embate: as divergências entre os que acreditam num sentido único e verdadeiro do texto e aqueles que o veem como um tecido (aliás, texto e tecido são etimologicamente próximos) de relações a partir do qual outras várias relações podem ser estabelecidas na leitura.

Richard Trachsler, em seu artigo sobre o percurso da medievalística no século XX, afirma que, depois dos anos 1970, a especialização e consequente fragmentação do conhecimento, bem como a disponibilidade de um grande leque de abordagens (estruturalismo, semiologia, lacanismo e correntes pós-modernas), tornavam impossível o consenso. ${ }^{93}$ Ele também parece lamentar esse que me parece o aspecto mais rico e salutar do período. Ao final de sua leitura, temos a impressão de que ele é nostálgico da filologia do século XIX!

Segundo esse crítico, novas ideias, como as expostas por Roland Barthes em "A morte do autor", dispensariam o medievalista de buscar a resposta impossível sobre qual texto empresta o que de quem (ainda as fontes!); afinal, todo texto seria um "'tissu de citations, issues des mille foyers de la culture', où l'auteur ne fait que 'mêler des écritures' qui lui viennent d'un 'dictionnaire composé' de ses lectures antérieures, voire de la culture ambiante". ${ }^{94}$ Segundo Trachsler, essa posição seria partilhada por Umberto Eco, que, em sua Apostille au 'Nom de la Rose', afirma: "les livres parlent entre eux", pouco importando, portanto, saber se tal autor está mesmo citando tal outro em seu texto. ${ }^{95}$

No entanto, a adoção dessas teorias por parte do medievalista é criticada pelo autor como uma solução fácil:

\footnotetext{
${ }^{91}$ BARTHES, R. Qu'est-ce que la critique? In : Essais critiques. Paris: Seuil, 1964. p. 261-266.

${ }^{92}$ NYKROG, P. Chrétien de Troyes: romancier discutable. Genève: Droz, 1996. p. 30.

93 TRACHSLER, R. Un siècle de lettreüre. Observations sur les études de littérature française du Moyen Âge entre 1900 et 2000. Cahiers de civilisation médiévale, Poitiers, n. 48, 2005, p. 366.

${ }^{94}$ Ibid., p. 371. As citações de Trachsler são de "A morte do autor": "'tecido de citações, provenientes dos mil centros da cultura', no qual o autor apenas 'amalgama escrituras' oriundas de um 'dicionário composto' de suas leituras anteriores, e mesmo da cultura ambiente".

${ }^{95}$ Ibid., p. 371: "os livros falam entre si".
} 
Cette position théorique, qui après 1970 allait de pair avec l'éclipse du monde de l'instance auctoriale, remplacée par le Récit d'un côté et par le Lecteur de l'autre, a, de fait, conduit les médiévistes à admettre par principe, pour leur période, un raisonnement élaboré à partir d'une situation historique correspondant à l'ère qui ne s'est ouverte qu'avec l'imprimerie. Or, probablement, pour la période médiévale, d'autres critères sont valables, les rapports entre les textes ne s'établissant pas aussi généralement et universellement qu'à l'èpoque moderne. L'adoption, plus ou moins inconsciente, de ce parti pris théorique se comprend pourtant facilement: c'était à la fois commode, puisqu'on s'évitait ainsi de longues et vaines recherches en bibliothèque, et stratégiquement habile dans la mesure où les études médiévales se montraient ainsi tout aussi à la pointe que celles sur les siècles voisins. ${ }^{96}$

O primeiro questionamento que surge a partir da citação de Trachsler é se realmente o raciocínio a que se refere é válido apenas para o período posterior à imprensa. O que justifica a utilização desse marco? Zumthor já mostrou que a imprensa não representa uma ruptura tão grande quanto se costuma afirmar e que a introdução da prática da leitura silenciosa foi mais decisiva na formação de um "espírito moderno" "97. Ora, a leitura silenciosa existiu muito antes da imprensa. Além disso, se a invenção de Gutenberg data de 1436, até meados do século XVI, impressão e manuscritura mais colaboraram uma com a outra do que concorreram. A mutação cultural ocorreu a muito longo prazo com efeitos completamente perceptíveis apenas no século XIX, com o ensino obrigatório, "que fará do impresso uma escritura de massa e acentuará o enfraquecimento das últimas tradições orais" 98 .

Um segundo questionamento se refere às relações entre os textos na Idade Média. $\mathrm{O}$ que Trachsler quer dizer exatamente ao afirmar que elas não se davam tão geral e universalmente quanto na época moderna? Se é verdade que a invenção da imprensa facilitou a circulação de textos entre letrados, é preciso lembrar que estes compunham ainda uma pequena parcela da população e que a oralidade não desapareceu com o surgimento da imprensa. Graças a essa oralidade, muitos textos circularam, sim, antes mesmo da imprensa,

\footnotetext{
${ }^{96}$ TRACHSLER, R. Un siècle de lettreüre. Observations sur les études de littérature française du Moyen Âge entre 1900 et 2000. Cahiers de civilisation médiévale, Poitiers, n. 48, 2005, p. 371-372: "Essa posição teórica, que, depois de 1970, acompanha o eclipse do mundo da instância autoral, substituída pela Narrativa, de um lado, e pelo Leitor, de outro, conduziu de fato os medievalistas a admitirem por princípio, para seu período, um raciocínio elaborado a partir de uma situação histórica correspondente à era que só se abriu com a imprensa. Ora, provavelmente, para o período medieval, outros critérios são válidos, as relações entre os textos não se estabelecendo tão geral e universalmente quanto na época moderna. A adoção, mais ou menos inconsciente, desse pressuposto teórico se compreende, entretanto, facilmente: era a um só tempo cômodo, já que se evitavam assim longas e vãs pesquisas em biblioteca, e estrategicamente hábil, na medida em que os estudos medievais se mostravam assim tão de ponta quanto aqueles sobre os séculos vizinhos". (grifos em negrito meus)

${ }^{97}$ ZUMTHOR, P. A letra e a voz: a "literatura" medieval. São Paulo: Companhia das Letras, 1993. p. 106.

${ }^{98}$ Ibid., p. 111.
} 
sem falar nas trocas entre scriptoria de mosteiros, que, em alguns momentos, pôde ser bastante intensa.

A circulação oral dos textos não pode ser subestimada, como mostra toda a obra de Zumthor. O medievalista suíço fala num "arquétipo" ou, retomando uma expressão de Menéndez Pidal, num "texto em estado latente" que os poetas trazem à vida por meio de sua voz, num aqui e agora, transformando-o. Esse universo do qual parte o texto da performance é familiar tanto ao intérprete quanto aos ouvintes. Nesse contexto, os textos dialogam e transformam-se a cada performance, pois, mesmo uma leitura pública de um texto escrito nunca é igual quando repetida. Assim, as variantes fazem parte dessa poesia. É o que Zumthor chama de "movência"99.

Em A letra e a voz, ele afirma:

Nas longas durações, a obra de memória constitui a tradição. Nenhuma frase é a primeira. Toda frase, talvez toda palavra, é aí virtualmente, e muitas vezes efetivamente, citação - de um modo pouco diferente do que acontecia na escritura dos letrados, em relação aos clássicos e aos Padres da Igreja, do século IX ao XII. ${ }^{100}$

Logo nos lembramos do texto de Barthes citado por Trachsler. Ora, nenhum medievalista desconhece a seriedade e a profundidade dos estudos de Zumthor, que, muito longe de embarcar comodamente num modismo, retira suas conclusões de árduas pesquisas não apenas sobre a poesia medieval, mas sobre outras culturas passadas e presentes de tradição oral. Assim, ao afirmar que toda palavra é citação, ele não está aplicando irrefletidamente uma categoria de análise moderna a um objeto passado. Além disso, note-se a "pouca diferença" entre as práticas da citação nos universos oral e escrito, o que enfraquece a objeção de Trachsler.

Finalmente, ao ironizar a adoção das novas posturas teórico-críticas por parte dos medievalistas, taxando-a de cômoda e estrategicamente hábil, Trachsler injustamente menospreza não apenas esses profissionais, mas também o pensamento de teóricos sérios, como Roland Barthes, possuidores - concordemos ou não com eles — do inegável mérito de levar os pesquisadores de diferentes áreas a se confrontar com novos problemas e, consequentemente, a considerar novas possibilidades.

\footnotetext{
${ }^{99}$ ZUMTHOR, P. A letra e a voz: a "literatura" medieval. São Paulo: Companhia das Letras, 1993. p. 143-144.

${ }^{100}$ Ibid., p. 143. (grifos meus)
} 
Ao final desse balanço, vemos que diferentes Chrétiens povoaram o período de apenas um século. Isso se deve à própria natureza da atividade crítica. "Le texte est toujours un miroir dans lequel le critique trouve sa propre image: chaque génération admire (ou méprise) en lui ce qu'elle admire (ou méprise) en général”, afirma Nykrog. ${ }^{101}$ Trata-se de uma constatação incômoda, pois evidencia a impossibilidade de um conhecimento objetivo e de uma tão almejada verdade definitiva, que resista a séculos futuros de pesquisas sobre um mesmo objeto. No entanto, queiram ou não os amantes da tranquilidade intelectual, não se trata de uma questão de escolha.

Barthes demonstrou o quanto a crítica positivista, pretensamente neutra e objetiva, também é ideológica. ${ }^{102}$ Para citar apenas um de seus argumentos, podemos dizer que, ao delimitar seu campo apenas sobre as circunstâncias da obra (biografia do escritor, por exemplo) a crítica positivista já faz uma escolha: ao não se perguntar sobre a essência da literatura (ou sobre se há uma essência), essa crítica já está respondendo à questão, ao tratar a literatura como algo natural, universal e atemporal. Contraditoriamente, tal crítica, que, caçadora de fatos, pretende-se histórica, torna-se a-histórica ao desconsiderar a historicidade da própria noção de literatura.

Isso significa que, no âmbito deste estudo, posso afirmar qualquer coisa sobre Chrétien? A resposta é não. O espelho nos permite a autocontemplação; mas também nos possibilita ver o que há atrás de nós, no caso, nove séculos!

Estamos aqui diante de uma tensão que caracteriza este trabalho, a qual, devo adiantar, não se resolverá em seus limites: colocar-me como um pesquisador brasileiro do século XXI que estuda uma obra do século XII, não de um ponto de vista arqueológico, de reconstituição do que significou Yvain para o público da época, mas do ponto de vista de alguém que lê um texto que continua vivo ainda hoje traz uma série de dificuldades.

Minha breve exposição sobre a Retórica antiga revela uma preocupação em respeitar a alteridade de Yvain ou le Chevalier au Lion. No entanto, procurar ver a chamada "Idade Média” com os olhos dela mesma, como já se propôs, consiste em pura ilusão.

Terry Eagleton, depois de ter mostrado como diferentes épocas se relacionam com a escritura e como cada uma lê um determinado autor de modo particular, propõe um interessante exercício de imaginação: suponhamos que "graças a alguma hábil pesquisa arqueológica" descobríssemos que as tragédias gregas significavam para seu público original

${ }^{101}$ NYKROG, P. Chrétien de Troyes: romancier discutable. Genève: Droz, 1996. p. 31: "O texto é sempre um espelho no qual o crítico encontra sua própria imagem: cada geração admira (ou despreza) nele o que admira (ou despreza) em geral".

${ }^{102}$ BARTHES, R. Les deux critiques. In : Essais critiques. Paris: Seuil, 1964. p. 255-260. 
muito mais do que pensávamos. Se reconhecêssemos que os novos aspectos descobertos estão muito longe de nossos interesses e, ainda assim, começássemos a ler as tragédias sob essa nova perspectiva, poderíamos deixar de apreciar essas peças. "Poderíamos passar a ver que delas gostávamos porque involuntariamente as líamos à luz de nossas próprias preocupações; quando tal interpretação tornou-se menos possível, o drama deixou de ter significado para nós."103

Isso mostra que a abordagem "arqueológica" não é necessariamente a melhor. No exemplo citado, ela serviria apenas para calar um texto, que, antes, tinha algo a dizer, ainda que algo diferente do que dizia na época de sua produção.

Michel Zink também reflete sobre essa questão. A citação a seguir, apesar de longa, merece estar presente não apenas por sua beleza, mas por apresentar, se não uma solução, ao menos um caminho para se viver a tensão de se trabalhar um objeto antigo no século XXI de modo mais salutar:

Le moyen âge est loin de nous. Si nous lui appliquons tout de go nos catégories mentales, notre sensibilité, nos convictions, elles nous induisent en erreur à son sujet. Seul un travail long et patient, seule une méfiance de chaque instant vis-à-vis de nous-mêmes peuvent nous permettre de peu à peu le comprendre et de rectifier nos erreurs. Tout cela est vrai, et d'ailleurs banal. Mais nous ne pouvons nous en contenter. Il faut bien partir de ce que nous dit cette littérature, même si ce qu'elle nous dit est faux au regard de l'hypothétique réalité du moyen âge telle que nous pouvons la reconstituer. Si nous nous contentons de sa fausse apparence, nous la condamnons et nous nous condamnons à la pauvreté. Mais si nous refusons l'erreur délicieuse où elle nous induit, quel désir aurons-nous d'elle? Que nous importera ce que nous saurons d'elle? Et comment découvrirons-nous le pourquoi de cette erreur si nous nous contentons de la récuser dédaigneusement sans nous y intéresser? Comment prétendre, à la lecture d'un texte, ignorer notre propre sensibilité et faire l'économie de notre jouissance sans être plus encore dupes de nous mêmes?

Peut-être l'historien peut-il se contenter d'une pure connaissance. Je n'en suis pas certain. Mais nous, dont l'objet n'existe que pour autant qu'il nous parle, nous sommes condamnés à ce va-et-vient sans fin, à ces corrections incessantes, à cette comparaison permanente entre ce que nous sentons et comprenons des textes et la lente et incertaine découverte de ce qu'ils donnaient peut-être, en leur temps, à sentir et à comprendre. Nous sommes condamnés... Douce condamnation! Cet exercice, qui est de la façon la plus essentielle le nôtre, notre champ et notre trésor, ne nous vaudra jamais la découverte d'une vérité définitive. Mais il nous donne à chaque instant ce plaisir propre aux lettres, ce plaisir esthétique et intellectuel sans être purement l'un ni l'autre, ce plaisir laborieux qui nous façonne et nous enrichit tandis que l'oeuvre prend forme et sens sous notre regard. ${ }^{104}$

\footnotetext{
${ }^{103}$ EAGLETON, T. Teoria da literatura: uma introdução. $5^{\text {a }}$ ed. São Paulo: Martins Fontes, 2003. p. 16.

104 ZINK, M. Trente ans avec la littérature médiévale. Note brève sur de longues années. Cahiers de civilisation médiévale, Poitiers, n. 39, 1996, p. 38-39: “A Idade Média está longe de nós. Se lhe aplicarmos livremente
} 
O vaivém permite não perder de vista nossas próprias motivações sem, no entanto, desrespeitar a alteridade do texto estudado. Assim, que Chrétien seja, neste trabalho, não ele mesmo o espelho no qual só vejo meu reflexo, o que, no limite, tornaria sua leitura dispensável, posto que qualquer texto poderia assumir função idêntica. Mas que eu possa vêlo através do espelho, sem me esquecer de mim mesmo.

\subsection{O exército de Clio}

O panorama da crítica de Chrétien de Troyes ao longo do tempo, empreendido por Per Nykrog, não termina nos anos 1970. Num último tópico, significativamente intitulado "contrapeso" (contrepoids), o dinamarquês traz à cena os historiadores da chamada "nova história", cuja importância para os estudos sobre Chrétien, a partir da década de 1980, teria sido capital:

Faisant contrepoids, de l'extérieur, aux diverses tendances "libérées" dans le grand cirque des lectures post-modernes de Chrétien, un groupe extrêmement important d'historiens a transformé, depuis une quinzaine d'années, l'image que les "littéraires" aussi sont obligés de se faire du contexte social du romancier et de son travail. ${ }^{105}$

nossas categorias mentais, nossa sensibilidade, nossas convicções, elas nos induzirão a erro a seu respeito. Somente um trabalho longo e paciente, somente uma desconfiança a cada instante em relação a nós mesmos podem nos permitir, pouco a pouco, compreendê-la e retificar nossos erros. Tudo isso é verdadeiro, e, aliás, banal. Mas não podemos nos contentar com isso. É mesmo preciso partir do que nos diz essa literatura, mesmo se o que ela nos diz é falso no que concerne à hipotética realidade da Idade Média tal qual nós podemos reconstituí-la. Se nos contentarmos com sua falsa aparência, nós a condenaremos e nos condenaremos à pobreza. Mas, se recusarmos o erro delicioso ao qual ela nos induz, que desejo teremos dela? Que nos importará o que saberemos dela? E como descobriremos o porquê desse erro se nos contentarmos em recusá-lo desdenhosamente sem nos interessarmos por ele? Como pretender, na leitura de um texto, ignorar nossa própria sensibilidade e dispensar nosso gozo sem enganarmos a nós mesmos ainda mais?

Talvez o historiador possa se contentar com um puro conhecimento. Não estou certo disso. Mas nós, cujo objeto existe apenas na medida em que nos fala, estamos condenados a esse vaivém sem fim, a essas correções incessantes, a essa comparação permanente entre o que nós sentimos e compreendemos dos textos e a lenta e incerta descoberta do que eles davam talvez, em seu tempo, a sentir e a compreender. Estamos condenados... Doce condenação! Esse exercício, que é do modo mais essencial, o nosso, nosso campo e nosso tesouro, não nos renderá nunca a descoberta de uma verdade definitiva. Mas ele nos dá, a cada instante, esse prazer próprio das letras, esse prazer estético e intelectual sem ser puramente nem um nem outro, esse prazer laborioso que nos modela e nos enriquece, enquanto a obra toma forma e sentido sob nosso olhar". (grifos meus)

${ }^{105}$ NYKROG, P. Chrétien de Troyes: romancier discutable. Genève: Droz, 1996. p. 34: "Fazendo contrapeso, de fora, às diversas tendências 'libertadas' no grande circo das leituras pós-modernas de Chrétien, um grupo extremamente importante de historiadores transformou, há cerca de quinze anos, a imagem que os 'literatos' também são obrigados a fazer do contexto social do romancista e de seu trabalho". (grifos meus) 
A partir da leitura dessa citação, tem-se a impressão de que as forças de Clio, musa da História, desembarcaram sobre o território dos estudos medievalísticos, dominado pelas forças do Caos, com o objetivo de libertá-lo. Vencida a guerra, os heróis civilizadores, sob o comando de Georges Duby e Jacques Le Goff, teriam instaurado a ordem, sem a qual não se poderia mais sobreviver nesse território, como se depreende do seguinte trecho:

Georges Duby et Jacques Le Goff dominent de haut cette nouvelle école, par leurs propres travaux et par l'inspiration qu'ils ont donné à de nombreux et savants élèves. Pour la réflexion sur Chrétien de Troyes en particulier, le savoir nouvellement acquis sur l'histoire et l'évolution de la chevalerie est d'une importance capitale (voir surtout Flori 1986), comme l'est aussi l'élucidation concise des structures familiales (constitution des lignées, mariages) et féodales (y compris les rituels). ${ }^{106}$

Ora, salvo se o estudioso de narrativas ficcionais se insere numa linha de pesquisa privilegiando as relações entre literatura e sociedade e, dentro dela, pertence a um subgrupo que acredita numa relação de determinação na qual o poético se subordina ao real, os elementos mencionados por Nykrog não são fundamentais para o estudo da poesia. Para o pesquisador interessado em práticas escriturais, processos de "criação" e outros fenômenos relativos ao fazer poético, o estudo da evolução da cavalaria e das estruturas familiares e feudais torna-se absolutamente dispensável.

Afinando-se com os comentários de Nykrog, Michel Zink acredita que estética literária, história e etnologia constituem o tripé que sustenta uma boa pesquisa sobre as letras na Idade Média, sendo desastrosa a falta de atenção do pesquisador a um desses três elementos. Ele também destaca a importância de Georges Duby e Jacques Le Goff, cujos seminários foram frequentados por inúmeros alunos, historiadores ou não, hoje medievalistas renomados. ${ }^{107} \mathrm{O}$ interesse dos estudiosos de literatura pelo discurso da História viria de um desejo de alargar seus horizontes inserindo suas pesquisas no quadro mais amplo da história

\footnotetext{
${ }^{106}$ NYKROG, P. Chrétien de Troyes: romancier discutable. Genève: Droz, 1996. p. 34: "Georges Duby e Jacques Le Goff dominam do alto essa nova escola, por seus próprios trabalhos e pela inspiração que deram a numerosos e sábios alunos. Para a reflexão sobre Chrétien de Troyes em particular, o saber recentemente adquirido sobre a história e a evolução da cavalaria é de uma importância capital (ver sobretudo Flori 1986), como o é também a elucidação concisa das estruturas familiares (constituição das linhagens, casamentos) $e$ feudais (inclusive os rituais)". (grifos meus) O autor se referiu a FLORI, J. L'essor de la chevalerie, XI XII siècles. Genève: Droz, 1986.

${ }^{107}$ ZINK, M. Trente ans avec la littérature médiévale. Note brève sur de longues années. Cahiers de civilisation médiévale, Poitiers, n. 39, p. 30, 1996.
} 
cultural. Esses profissionais talvez fossem movidos por um desencanto com o que Trachsler considera "os excessos" $" 108$ dos anos 1970.

Bem, o panorama exposto a partir dos textos de Nykrog, Zink e Trachsler mostra o ponto de vista europeu, notadamente francês. Interessante observar como o fato de estudar Chrétien de Troyes no Brasil promove um deslocamento que altera essa perspectiva.

Em nosso país, apesar de medievalistas se destacarem em diferentes áreas, a predominância dos historiadores é inconteste. Mesmo dentre os estudiosos de "literatura medieval" - nosso interesse mais imediato —, muitos dialogam intimamente com historiadores dedicados à história social e à história da cultura.

Mas os profissionais franceses dedicados à história da Idade Média possuem maior repercussão internacional que os especialistas na poesia do mesmo período. Portanto, o deslocamento a que me referi não diz respeito a esse predomínio da História. A mudança de perspectiva se dá por outro motivo: no Brasil, em razão do caráter relativamente recente dos estudos sobre o medievo, os pesquisadores da poesia medieval não viveram a euforia europeia pelas novas ideias dos anos 1970 mencionadas por Trachsler. Portanto, reflexões e questionamentos sobre, por exemplo, a morte do autor, a autonomia do campo literário e as noções de escritura e de reescritura por parte do "receptor" não preocupam, de modo geral, os estudiosos brasileiros da poesia da época de Chrétien.

Assim, se, na França, o recurso à História serviu para abrir um novo horizonte para o pensamento e para compensar supostos excessos imanentistas, no Brasil o império da História no campo dos estudos medievais não vem como contrapeso de uma realidade anterior. Não há realidade anterior. A medievalística brasileira já nasce sob o signo da História. Quanto aos não historiadores, relacionavam-se estreitamente com a disciplina de Le Goff e Duby ou concentravam-se no estudo da filologia. De um modo ou de outro, não consideravam as tendências das décadas de 1960 e 1970 na Europa, às quais os historiadores franceses teriam vindo impor limites.

Enfim, no campo brasileiro das pesquisas sobre a Idade Média, os historiadores representam a ordem, o já dado, o estabelecido. Diferentemente do caso europeu, no qual se apresentaram como uma nova opção, apresentam-se aqui quase como caminho único, o que se torna sem dúvida empobrecedor.

\footnotetext{
108 TRACHSLER, R. Un siècle de lettreüre. Observations sur les études de littérature française du Moyen Âge entre 1900 et 2000. Cahiers de civilisation médiévale, Poitiers, n. 48, p. 372, 2005. Trachsler admite, no entanto, a importância das novas ideias no combate a um positivismo ainda detectável nos anos 1960 .
} 
Não se trata aqui de atacar os historiadores. O alargamento das abordagens por parte da chamada "nova história" possibilitou um enriquecimento indiscutível das ciências humanas. A diversificação dos objetos dignos de interesse para o historiador também fazem parte desse processo. Assim, hoje, um historiador pode se debruçar sobre um texto poético para, inteligentemente e cercando-se dos devidos cuidados, enriquecer seu estudo sobre, por exemplo, os valores, anseios, frustrações e a mentalidade da sociedade que o produziu. Ele não precisa mais se limitar aos documentos oficiais tradicionais. Evidentemente, o texto poético tem sua especificidade e o historiador precisa saber lê-lo, interrogá-lo, evitando associações diretas e relações deterministas com o real. Ou seja, o historiador pode utilizar o texto literário como uma fonte entre outras para seus estudos de uma sociedade. Não se trata de negar isso a ele. Trata-se, sim, de reivindicar o direito de, como estudiosos de poesia, não o fazermos. Assim, numa perspectiva "literária", o texto poético é o alvo e não o meio para se atingir um fim.

Portanto, na França, a visão dos historiadores veio acrescentar algo ao quadro já existente e não se trata aqui de negar esses contributos. Mas, valendo-nos da mesma lógica, não podemos ignorar o fato de que as reflexões sobre a linguagem e sobre a literatura elaboradas nas décadas de 1960 e 1970 devem ser consideradas pelo pesquisador brasileiro da poesia medieval, pois, no seu contexto dominado pelos historiadores ou por posturas historicizantes, elas certamente ainda têm algo a dizer.

\subsection{Yvain e a Esfinge}

Um breve comentário sobre diferentes análises de Yvain ou le Chevalier au Lion permite verificar o tipo de abordagem predominante entre aqueles que se dedicaram ao estudo desse poema narrativo.

Num de seus estudos, Jacques Le Goff propõe um esboço de análise de um romance cortês $^{109}$. O recorte adotado é o episódio da loucura de Yvain. Apesar de trechos bastante interessantes, esse texto é de pouca valia para aqueles que se preocupam com a prática da escritura poética, pois todo o esforço do historiador culmina em mera ilustração de esquemas

\footnotetext{
${ }^{109}$ LE GOFF, J. Esboço de análise de um romance cortês. In: medieval. Lisboa: Edições 70, 1990. p. 107-150. . O maravilhoso e o quotidiano no Ocidente
} 
históricos ${ }^{110}$ (os termos são dele). O resultado parece-me pouco útil até mesmo para os historiadores, já que essa interpretação de Yvain não revela nada, apenas ilustra conhecimentos já adquiridos por intermédio de trabalhos de outros pesquisadores citados por Le Goff, como Georges Duby e Erich Köhler.

Passando do campo da História para o campo das Letras, percebe-se que a abordagem nem sempre se modifica. Claude Lecouteux, num de seus artigos ${ }^{111}$, adota uma personagem como objeto de análise: o gigante Harpin de la Montagne, que Yvain se propõe a enfrentar para evitar a desgraça da família de Gauvain, seu grande companheiro de armas.

No início do artigo, o vocabulário de Lecouteux demonstra uma atenção a questões textuais, tais como função de um episódio na economia geral da obra, arte do poeta e seu modo de entrelaçar os diferentes fios da ação. Mas, pouco antes da metade do artigo, o autor levanta uma questão: "Se pourrait-il que Harpin fût autre chose qu'un géant?"112. Buscar o sentido oculto do texto constitui uma prática comum entre os medievalistas, muitos dos quais abusam da ideia de um simbolismo medieval. É verdade que a alegoria é um dos traços caracterizadores do pensamento dos homens do período, mas isso não equivale a dizer que todas as passagens de todos os textos dessa época sejam alegóricas. ${ }^{113}$

Nesse ponto de seu artigo, Lecouteux se desvia de preocupações propriamente textuais e caminha em direção à realidade histórica do período para demonstrar - com argumentos pouco convincentes, dos quais tira conclusões muito apressadamente - que o gigante Harpin representa um tipo social específico: o camponês enriquecido que compra um senhorio e passa a viver como um cavaleiro, sem, no entanto, partilhar de seus valores. Assim, a personagem consistiria na transposição de um elemento real para a esfera do maravilhoso, ou seja, o texto não seria mais que pretexto para uma crítica social.

O sentido oculto buscado pelos críticos não diz respeito exclusivamente a uma questão social. Num de seus textos dedicados a Yvain, Philippe Walter analisa o papel desempenhado pelo tempo na narrativa, considerado por ele um dos inimigos do herói e talvez o mais importante ${ }^{114}$. Há trechos interessantes e, inicialmente, o autor parece de fato se preocupar

\footnotetext{
${ }^{110}$ LE GOFF, J. Esboço de análise de um romance cortês. In: medieval. Lisboa: Edições 70, 1990. p. 136.

${ }^{111}$ LECOUTEUX, C. Harpin de la Montagne. Cahiers de civilisation médiévale, Poitiers, n. 30, p. 219-225, 1987.

${ }^{112}$ Ibid., 221: "Seria possível que Harpin fosse outra coisa que não um gigante?".

${ }^{113}$ Não distingo aqui símbolo de alegoria, baseando-me na ideia de que tal distinção inexiste no período medieval. Sobre isso, ver especificamente a página 246 de: STRUBEL, A. Le sens de l'écriture et le déchiffrement du monde: le Moyen Âge. In: LESTRINGANT, F.; ZINK, M. (Dir.). Histoire de la France littéraire. Paris: P.U.F., 2006. v. 1. p. 237-262.

${ }^{114}$ WALTER, P. Temps romanesque et temps mythique: éléments pour une recherche. In: DUFOURNET, J. Le Chevalier au Lion: approches d'un chef-d'oeuvre. Paris: Champion, 1988. p. 195-217.
} 
com questões literárias. Mas, a partir de certo ponto da leitura, torna-se evidente que o poema de Chrétien funciona apenas como trampolim para acrobacias intelectuais do crítico. Este passa a perseguir algo que estaria para além da narrativa, a qual parece cair para segundo plano. Assim, o texto é considerado um código a ser decifrado para se atingir uma realidade oculta, não mais histórico-social, mas, dessa vez, mítica. Comentários instigantes, se considerados isoladamente, acabam contaminados por posições críticas absolutamente insustentáveis. Uma delas concerne ao leão que passa a acompanhar e servir o herói depois de ter sido salvo por ele do ataque de uma serpente cuspidora de fogo. Em meio às interpretações que lhe parecem plausíveis, o autor insere um breve comentário, segundo o qual o leão é "probablement le signe zodiacal de naissance d'Yvain" "15! Ora, Yvain é uma personagem e não uma pessoa e, portanto, não possui um signo zodiacal! Ele mesmo é um conjunto de signos, mas linguísticos!

Essas ideias apresentam-se mais desenvolvidas num livro ${ }^{116}$ do mesmo ano. Nele, Walter procura interpretar episódios e personagens do romance de Chrétien buscando seus substratos míticos. Assim, cada um deles esconderia traços de uma mitologia ancestral comum de base indo-europeia. Ao analisar esses elementos, Walter mantém-se atento ao aspecto temporal, pois todo o poema se construiria baseado numa espécie de calendário cósmico-mitológico. Portanto, percebe-se que o analista desvia-se duplamente do texto de Chrétien: por um lado, preocupa-se demais com supostas fontes e, por outro, essas mesmas fontes, relacionadas à interpretação de Yvain, o levam a concluir que o interessante é o que está para além do poema, ou seja, esse sistema mítico ao qual Le Chevalier au Lion faria referência.

Michel Stanesco, em 1981, também dedica um artigo $^{117}$ a Yvain, no qual considera uma possível origem mítica da narrativa. Mas, em sua conclusão, ele chama a atenção para uma questão importante: não se pode julgar Chrétien a partir de suas supostas fontes, como já se fez, uma vez que a matéria do romance (o mito) não é o romance.

Dos livros dedicados exclusivamente a Yvain ou le Chevalier au Lion, o grande clássico $^{118}$ leva a assinatura de Jean Frappier. Trata-se de uma leitura muito interessante, na

\footnotetext{
${ }^{115}$ WALTER, P. Temps romanesque et temps mythique: éléments pour une recherche. In: DUFOURNET, J. Le Chevalier au Lion: approches d'un chef-d'oeuvre. Paris: Champion, 1988. p. 216: "provavelmente o signo zodiacal de nascimento de Yvain".

${ }^{116}$ WALTER, P. Canicule: essai de mythologie sur Yvain de Chrétien de Troyes. Paris: SEDES, 1988.

117 STANESCO, M. Le Chevalier au Lion d'une déesse oubliée. Yvain et "Dea Lunae". In: d'amour. Orléans: Paradigme, 2002. p. 79-96.

${ }^{118}$ FRAPPIER, J. Étude sur Yvain ou le Chevalier au Lion de Chrétien de Troyes. Paris: SEDES, 1969. . D'armes et
} 
qual é possível reconhecer a base de discursos reproduzidos sistematicamente pela crítica, mas que, aqui, aparecem muito mais bem fundamentados.

O título já revela o caráter abrangente da empreitada: o autor pretende analisar a obra como um todo, não elegendo um aspecto específico. Numa abordagem legitimamente literária, ele se volta para o texto de Chrétien. Embora não abandone a preocupação com as fontes, dedicando-lhes todo um capítulo, Frappier não se deixa dominar por ela, reservando espaços significativos para questões relativas à versificação, à coerência da intriga, ao entrelaçamento dos episódios, à composição das personagens, à elaboração de descrições e ao emprego de comparações e metáforas.

Sua crítica é interpretativa, o que o leva a separar um capítulo para discutir o sentido da obra, o qual giraria em torno das concepções de amor e de cavalaria.

Aborda os aspectos maravilhosos da narrativa, mas não deixa de lado os elementos da realidade do século XII, que considera uma das fontes do poema. Outros textos do período, como os romances de Antiguidade, já haviam posto em cena traços da realidade feudal, mas, para Frappier, os modos de fazê-lo distinguem Chrétien dos demais. Um desses modos é a mistura entre aspectos da realidade social e cotidiana com o maravilhoso bretão. ${ }^{119}$

A abrangência do estudo de Frappier é a chave de sua atualidade quarenta anos após sua publicação. Nele se encontram justificativas para diferentes abordagens coexistentes em nossos dias, tais como interpretações do sentido geral da obra, análises voltadas para as relações entre texto literário e realidade social, busca de fontes e, por fim, análises estritamente formais. Diante disso, evidentemente, os pesquisadores de diferentes tendências não conseguirão se identificar com todas as partes do livro de Frappier. Mas hão de reconhecer seu grande mérito de propor uma análise, antes de tudo, Literária.

Pouco mais de vinte anos depois de Frappier, Emmanuèle Baumgartner publica um livro ${ }^{120}$ em que pretende também analisar Yvain, mas não exaustivamente. Sua proposta reside em demonstrar que, possivelmente compostos ao mesmo tempo, Le Chevalier au Lion e Le Chevalier de la Charrette formam um díptico, tratando de modos diferentes um mesmo problema: o confronto do cavaleiro com as virtudes e os perigos do amor. ${ }^{121}$ Embora a autora não o explicite em sua introdução, percebe-se, em sua análise comparativa, uma preocupação em interpretar o sentido das duas obras. Mas, diferentemente de Frappier, ela concentra toda sua análise no plano da história, ignorando elementos formais. Ela se dedica ao estudo de

\footnotetext{
${ }^{119}$ FRAPPIER, J. Étude sur Yvain ou le Chevalier au Lion de Chrétien de Troyes. Paris: SEDES, 1969. p. 118-131.

${ }^{120}$ BAUMGARTNER, E. Chrétien de Troyes: Yvain, Lancelot, la charrette et le lion. Paris: P.U.F., 1992.

121 Ibid., p. 6.
} 
motivos, mais em sua relação intertextual com supostas fontes e com narrativas posteriores que em sua própria textualidade, numa abordagem exclusivamente temática, que se torna cansativa por seus excessos.

Considero excessivo, por exemplo, baseando-se em supostas fontes orais, tratar as personagens femininas Laudine e Lunete como fadas, já que o poema não as nomeia desse modo. É verdade que Frappier ${ }^{122}$ também considera Laudine uma fada e que, para Laurence Harf-Lancner ${ }^{123}$, as personagens feéricas não são necessariamente marcadas, ou seja, nomeadas como tal, sendo possível reconhecê-las a partir de certos indícios que sinalizam sua entrada em cena. Mas esses autores justificam suas posições, permitindo-nos concordar ou não com eles. O que me parece abusivo é aprioristicamente utilizar o termo fada para caracterizar as personagens mencionadas sem nenhuma justificativa, como se se tratasse de um dado indiscutível. Ora, a partir do momento em que o poema não menciona fadas, todo crítico que assim vê as personagens deve justificar sua interpretação. Além disso, Nykrog ${ }^{124}$ nos lembra de que afirmar a filiação de uma dada personagem a uma figura feérica não significa muita coisa. Que os contos celtas foram importantes para Chrétien, não se faz mais necessário demonstrar. Mas seus empréstimos, mesmo os mais visíveis, foram tão modificados que, ainda quando possível remontar a suas origens, isso não acrescentaria nada fundamental à leitura daquilo em que Chrétien efetivamente os transformou.

Percebe-se também no texto de Baumgartner uma tendência muito difundida entre os medievalistas: a de psicologizar em demasia as ações das personagens, como se pudéssemos colocá-las num divã. Sabe-se que muitos estudiosos da literatura recorrem a princípios da psicanálise para analisar, por exemplo, processos escriturais, realizando trabalhos refinados de crítica literária. Mas não se trata disso aqui. Baumgartner, como muitos medievalistas, parece se esquecer de que não estamos diante de pessoas. É verdade que Chrétien brilha ao explorar a interioridade de suas personagens, mas muitos críticos levam isso ao exagero e acabam propondo superinterpretações, nas quais pretendem enxergar o que se passa dentro da "mente" dessas criaturas. Ora, como seres de papel, as personagens não possuem uma mente e, assim, essas interpretações incorrem facilmente em excessos. ${ }^{125}$

\footnotetext{
${ }^{122}$ FRAPPIER, J. Étude sur Yvain ou le Chevalier au Lion de Chrétien de Troyes. Paris: SEDES, 1969. p. 102-106.

${ }^{123}$ HARF-LANCNER, L. Les fées au Moyen Âge. Paris: Honoré Champion, 1984. p. 35-36.

124 NYKROG, P. Chrétien de Troyes: romancier discutable. Genève: Droz, 1996. p. 51.

125 Inspiro-me aqui nos comentários elaborados por Béatrice Didier acerca das personagens de Les liaisons dangereuses, de Laclos (DIDIER, B. Commentaires. In: LACLOS, C. de. Les liaisons dangereuses. Paris: Le Livre de Poche, 1993. p. 535-584), e no artigo: HAMON, P. Pour un statut sémiologique du personnage. Littérature, Paris, n. 6, p. 86-110, mai 1972.
} 
O capítulo que Nykrog dedica a Yvain, em seu Romancier discutable ${ }^{126}$, lembra em muitos pontos o texto de Baumgartner. Ambos se preocupam em propor uma interpretação da obra, ambos se detêm no plano da história e, finalmente, ambos exageram na exploração da interioridade das personagens. No entanto, todas essas críticas que havia dirigido ao texto da medievalista francesa devem ser atenuadas no caso de Nykrog. Primeiramente porque, apesar dos exageros mencionados, o crítico dinamarquês parece ouvir o texto mais de perto e se opõe, por exemplo, à tendência de considerar Lunete uma fada. Além disso, apesar de utilizar a maioria das páginas de seu capítulo para comentários que se atêm ao plano da história, Nykrog considera também questões relativas à construção do texto, como a disposição das peças do jogo narrativo e o entrelaçamento de episódios. Finalmente, o autor chama a atenção para os efeitos ${ }^{127}$ provocados por esses elementos constitutivos do poema. Tudo isso torna o texto de Nykrog sensivelmente mais atraente que o de Baumgartner.

Os críticos também produziram textos destinados a examinar um aspecto específico de Le Chevalier au Lion.

Em 1989, Michel Stanesco publica um artigo ${ }^{128}$ em que se propõe a estudar o leão, companheiro de Yvain que figura no título moderno. Mesmo que de forma mais arejada que outros e atento a novos questionamentos, ele também se preocupa fundamentalmente em chegar ao sentido da obra, o que, nesse caso, se faz pela interpretação de uma personagem. Assim, o sentido do leão revelaria o sentido das aventuras de Yvain, ou seja, o crítico parte de um elemento particular cujo interesse residiria em desvelar o todo.

Um ano antes, Dufournet publicara um livro inteiro dedicado a Yvain ou le Chevalier au Lion ${ }^{129}$, em que assina um capítulo, enquanto os outros nove são redigidos cada qual por um especialista diferente. $\mathrm{O}$ traço comum a todos os textos reunidos nesse volume consiste no fato de que cada especialista adota um recorte específico, diferindo, portanto, de outras análises nas quais, como vimos, seus autores pretendem examinar o poema como um todo.

Num desses capítulos, Francis Dubost ${ }^{130}$ adentra o universo do Cavaleiro do Leão partindo de um conceito de maravilhoso próximo daquele proposto por Le Goff. Dubost estuda, numa primeira parte do texto, o que chama de sistema de credibilidade, ou seja, as bases sobre as quais se organizaria uma possível crença em maravilhas. Numa segunda parte,

\footnotetext{
${ }^{126}$ NYKROG, P. Le masque et le visage. In: Chrétien de Troyes: romancier discutable. Genève: Droz, 1996. p. 151-178.

127 Prefiro colocar a questão em termos de efeito e não de intenção, como faz Nykrog, pois considero muito problemática a ideia de uma intenção autoral, sobretudo aplicada a um autor do século XII sobre o qual não sabemos absolutamente nada.

${ }^{128}$ STANESCO, M. Le Lion du Chevalier. In: ___ _ D'armes et d'amour. Orléans: Paradigme, 2002. p. 97-127.

${ }^{129}$ DUFOURNET, J. (Org.). Le Chevalier au Lion: approches d'un chef-d'oeuvre. Paris: Champion, 1988.

${ }^{130}$ DUBOST, F. Merveilleux et fantastique dans Le Chevalier au Lion. In: DUFOURNET, op. cit., p. 47-76.
} 
o autor defende a ideia de um afastamento do maravilhoso por parte de Chrétien, o qual se evidenciaria não apenas pelo fato de ele ter situado sua narrativa num outro tempo e num outro lugar, mas, sobretudo, por meio da ironia com que o poeta trataria seus temas. A partir do aprofundamento dessas questões, ele chega à elaboração do conceito de um fantástico medieval. Retomarei adiante as ideias de Dubost, pois relacionam-se diretamente com meu recorte.

Outro capítulo $^{131}$, muito interessante, traz as reflexões de Philippe Ménard sobre o riso e o humor em Yvain. Inicialmente, ele parece concordar com Dubost sobre o distanciamento em relação ao maravilhoso, mas não o aponta como uma postura autoral de Chrétien de Troyes, e sim como uma tendência geral do romance em relação à canção de gesta. Mas, logo em seguida, o autor admite que, se há sorrisos na obra, o humor não é sua característica predominante e que aqueles que assim o consideraram, fizeram-no abusivamente. Apesar de, ao longo de seu texto, fazer um levantamento dos elementos cômicos presentes em Yvain — os quais reconheço como tal apenas na menor parte das vezes - conclui sua análise marcando claramente sua posição: Chrétien pode eventualmente se divertir com o maravilhoso, mas o tom geral do poema fica muito longe da paródia. O poeta não ri de prodígios e mistérios nem põe em dúvida certos fenômenos, como o da cruentation $^{132}$. Um ponto interessante na argumentação de Ménard é que ele considera o contexto de recepção medieval, já comentado anteriormente: a obra se dá a conhecer numa performance e depende de um intérprete. Este pode reforçar o humor de certas passagens ou mesmo provocar uma impressão de humor onde o texto não sugere necessariamente sua existência. Assim, fica claro que o cômico não é essencial, mas circunstancial, dependendo de uma oralização mais ou menos bem-sucedida.

Emmanuèle Baumgartner ${ }^{133}$ adota como recorte o episódio da fonte da tormenta, uma fonte mágica cuja água não para de ferver e, ainda assim, mantém-se extremamente fria. Perto dela, há uma bacia de ouro pendurada a uma corrente. Sempre que alguém a utiliza para colher um pouco da água da fonte e despejá-la sobre a grande esmeralda que jaz a seu lado, apoiada em quatro rubis, desencadeia-se uma horrível tempestade. Nesse texto, mais que em seu livro mencionado anteriormente, a autora atenta para questões formais. Ela tece

\footnotetext{
${ }^{131}$ MÉNARD, P. Rires et sourires dans le roman du Chevalier au Lion. In: DUFOURNET, J. (Org.). Le Chevalier au Lion: approches d'un chef-d'oeuvre. Paris: Champion, 1988. p. 7-29.

${ }^{132}$ Trata-se de uma crença do período, segundo a qual um cadáver sangra em presença de seu assassino. Quanto a esse ponto, Ménard vai de encontro ao pensamento de Dubost, que cita justamente um episódio de cruentation em Le Chevalier au Lion como um dos exemplos de distanciamento irônico de Chrétien em relação às maravilhas.

${ }^{133}$ BAUMGARTNER, E. La fontaine au pin. In: DUFOURNET, op. cit., p. 31-46.
} 
comentários interessantíssimos sobre as diferentes descrições da fonte por diferentes personagens, associando-as ao foco narrativo. Mas seu objetivo continua sendo propor uma interpretação, e, nesse sentido, afasta-se de meu interesse.

Douglas Kelly, num texto muito instigante ${ }^{134}$, estuda o “jogo da verdade” em Yvain. É um dos únicos - ao lado apenas de Dubost e Ménard — que não se propõe a descobrir o sentido oculto de uma passagem, de uma personagem ou de um objeto. Mesmo estabelecendo relações com a história do período, Kelly prioriza a textualidade, não considerando o poema um reflexo do real. Ele analisa como as personagens, sobretudo Lunete e Laudine, se relacionam com a verdade. Kelly recorre à Retórica antiga, mais precisamente a Quintiliano, para mostrar como Lunete - por meio da lógica e da manipulação discursiva, ora omitindo, ora dissimulando, ora revelando a verdade - persuade Laudine em diferentes ocasiões. Isso tudo determina a sequência dos acontecimentos. Assim, ao atentar para essas questões, o crítico, em vez de interpretar uma "mensagem" do texto, examina o funcionamento de um de seus aspectos. Trata-se do tipo de abordagem que proporei nos dois próximos capítulos.

Finalmente, Jean Subrenat escreve um dos capítulos mais interessantes do volume ${ }^{135}$. Seu título em forma de interrogação já anuncia o espírito investigativo do autor, cuja proposta é bastante frutífera: diante de alguns estranhamentos sentidos durante a leitura, Subrenat se pergunta sobre a função da passagem do combate do herói contra os filhos do Netun (espécie de diabo), que, embora brilhante, parece-lhe relativamente desvinculada das demais, ao menos à primeira vista. Sabendo que Chrétien se vangloriou em seus textos de sua conjointure - sua arte da composição - , o pesquisador decide desconfiar dessa primeira impressão e tentar responder se, contrariamente a ela, o episódio em questão não consistiria numa peça essencial da estrutura da obra. Se assim for — pergunta-se —, qual o seu sentido? É por meio de uma leitura atenta do relato do combate que o autor pretende resolver essas questões.

Ao longo desse capítulo, Subrenat estabelece relações interessantes entre seu recorte e outras passagens do romance e mesmo de Érec et Énide, mas, perto do final, decepciona quando começa a interpretar, pois, como autores de outros capítulos do volume, passa muito rapidamente a soluções de tipo alegórico e, em menor medida, psicologizante. De qualquer modo, esse texto, não por suas conclusões, mas por sua abordagem, vem ao encontro da proposta inicial deste trabalho, como veremos adiante.

\footnotetext{
${ }^{134}$ KELLY, D. Le jeu de la vérité. In: DUFOURNET, J. (Org.). Le Chevalier au Lion: approches d'un chefd'oeuvre. Paris: Champion, 1988. p. 105-117.

${ }^{135}$ SUBRENAT, J. Pourquoi Yvain et son lion ont-ils affronté les fils de Nétun? In: DUFOURNET, op. cit., p. 173-193.
} 
O precedente balanço não pretendeu esgotar a produção crítica relativa a Yvain ou le Chevalier au Lion, tarefa efetivamente impossível dada a quantidade de publicações sobre Chrétien de Troyes ao redor do mundo. Busquei apenas oferecer ao leitor uma ideia do tipo de abordagem do texto poético predominante entre os medievalistas. Assim, vimos o quanto se valoriza, em medievalística, a questão das fontes, relativamente abandonada por especialistas da poesia de outros períodos. Vimos também como os analistas se comportam diante de Yvain tal qual Édipos perante a Esfinge. Tanto abordagens da obra como um todo quanto aquelas que recortam um de seus aspectos visam a uma interpretação, isto é, a encontrar o sentido oculto da narrativa. Este é visto ora na realidade social do período, ora numa mitologia ancestral, ou seja, o texto sempre remeteria a algo exterior a ele. Vimos, finalmente, o quanto se abusa de leituras simbólicas ou alegóricas e também de psicologizações das personagens nessas tentativas de interpretação.

Nos romances da Távola Redonda, a corte de Arthur corresponde ao mundo conhecido, desbravado, civilizado, enfim, ao mundo das realidades estabelecidas. Nesse sentido, este primeiro capítulo corresponde à corte desse rei legendário, na medida em que, por meio dele, o leitor brasileiro toma contato com aquilo que já é dado, assente — ou, pelo menos, tido como tal - em relação aos estudos sobre Chrétien de Troyes. Da corte de Arthur partem os cavaleiros em busca de aventura. Do mesmo modo, esse universo crítico foi meu ponto de partida, o que significa que partilhei inicialmente de suas crenças, preocupações, posturas e procedimentos. Mas, no momento mesmo em que partimos de um lugar, começamos a nos distanciar dele. Aqui se inicia minha errância... 


\section{CAPÍTULO 2: ERRÂNCIA...}

Dos sete poemas narrativos atribuídos a Chrétien de Troyes - Érec et Énide; Cligès; Lancelot ou le Chevalier de la Charrette; Yvain ou le Chevalier au Lion; Perceval ou le conte du Graal; Philomena e Guillaume d'Angleterre — há unanimidade apenas quanto à atribuição de autoria dos cinco primeiros, embora um número cada vez maior de críticos considere Philomena entre esse leque de certezas. Embora toda ficção dita "medieval" interesse, Chrétien de Troyes é para mim uma grande referência. E continuaria sendo-o, ainda que não primasse pelas qualidades estilísticas atualmente reconhecidas pela crítica, por uma simples questão afetiva: num mercado editorial saturado por best-sellers de qualidade discutível e cuja intriga se situa na Europa feudal - embora a linguagem e as personagens mantenham-se modernas —, Chrétien foi minha primeira leitura legitimamente "medieval". Assim, ao decidir instalar na chamada "Idade Média" o meu posto de observação dos fenômenos poéticos, o poeta da Champanha se apresentava quase que naturalmente como um objeto de estudo. No início deste trabalho, estando ainda muito pautado pelas noções tradicionais de autor e de obra, decidi escolher o texto sobre o qual iria refletir entre aqueles seguramente saídos "da pena" ${ }^{137}$ de Chrétien. Depois de muito custo, escolhi Yvain ou le Chevalier au Lion, sem saber ao certo o porquê, movido apenas pela sensação de que, se todos esses textos consistiam numa fonte de prazer, Yvain exercia sobre mim uma atração especial. $^{138}$

Uma vez que se trata de obra pouquíssimo conhecida no Brasil, considero útil fornecer um pequeno resumo da história, para que se possa acompanhar melhor o meu percurso de leitura do poema.

As aventuras de Yvain iniciam-se com um relato dentro do relato. Um cavaleiro de nome Calogrenant, primo do protagonista, conta a seus companheiros uma aventura ocorrida há mais de sete anos. Aventura incompleta e malsucedida, culminando na vergonha sobre a qual o cavaleiro calara até então. Depois de muito tempo cavalgando na floresta de Broceliande, Calogrenant passa a noite num castelo, no qual é honrosamente recebido. Pouco após a partida, na manhã seguinte, ele chega a um roçado, no qual touros selvagens lutam produzindo grande barulho. É então que vê um boieiro cuja feiura o impressiona. Descrever

\footnotetext{
${ }^{136}$ Por trás desse adjetivo anacrônico, que sugere uma falsa homogeneidade, escondem-se realidades bastante distintas.

${ }^{137}$ Vimos, no capítulo 1, o quanto essa perspectiva, em se tratando do século XII, revela-se ilusória.

${ }^{138}$ Vê-se que, aqui, não saíra ainda da "corte de Arthur" e que, segundo o costume — tão importante na literatura arturiana - buscava uma obra para analisar como um todo e interpretar.
} 
tal aparência parece impossível — e, no entanto, ele o fará até mesmo com certa riqueza de detalhes, como veremos em outro momento. Calogrenant afirma estar em busca de aventura, termo que o guardador de touros parece desconhecer. No entanto, ele conhece algo que, diz, certamente interessará ao cavaleiro. E descreve uma fonte maravilhosa ao pé de uma árvore que nunca perde suas folhas, mesmo no inverno. Junto à fonte, há uma pedra. Despejando-se as águas da fonte sobre essa pedra, desencadeia-se uma tempestade de violência jamais vista. O responsável pela tormenta tem muita sorte se conseguir escapar sem sofrimento.

Calogrenant deixa-se seduzir pelo que lhe parece uma aventura sem igual. Chegando à fonte de Landuc, descobre detalhes da paisagem que não haviam sido mencionados pelo guardador de touros. Descobre também que à tempestade sucede uma calmaria paradisíaca, embalada por um magnífico canto de pássaros. Esse estado de elevação não dura muito, pois logo se ouve o cavalgar do defensor daquelas terras, Esclados o Ruivo. Calogrenant é vencido em combate singular e parte humilhado.

Yvain decide experimentar essa aventura, movido pelo desejo de vingar o primo, mas também pelo anseio de contemplar com os próprios olhos as maravilhas mencionadas: o camponês de aspecto monstruoso e a fonte mágica. O herói realiza seus desejos, e a situação culmina na morte de Esclados, mas Yvain se vê preso numa espécie de armadilha junto com o cadáver. Entretanto, Lunete - dama de companhia de Laudine, a viúva, senhora de Landuc —, por uma dívida de gratidão, auxilia Yvain, oferecendo-lhe um anel de invisibilidade. Os cortesãos, enfurecidos pelo fato de terem visto seu senhor ser perseguido até as muralhas do castelo, vêm à procura do assassino, mas não encontram ninguém.

Yvain, que tudo vê sem ser visto, apaixona-se por Laudine. Esta, em consequência da intervenção astuciosa de Lunete, consente em desposar o assassino do próprio marido. Nada disso se passa sem que o autor dedique vários versos à exploração da interioridade de cada personagem em conflito.

Após vários dias de júbilo, durante os quais o rei Arthur e sua corte foram recebidos em visita a Landuc, Yvain pede a sua esposa permissão para partir com Gauvain, seu grande companheiro de armas, em busca de aventuras. Ela concede-lhe o prazo de um ano, ao fim do qual, se ele não retornar, sua união será considerada rompida. O fato é que o cavaleiro esquece o prazo estabelecido e, ao se dar conta disso, vive tamanha crise de consciência que passa por um período de loucura, vivendo na floresta como um animal selvagem.

É curado por um unguento mágico, e, a partir daí, começa seu périplo. Erra pelo mundo, auxiliando os necessitados, mas seu verdadeiro objetivo é a obtenção do perdão de sua amada. Contudo, antes de conquistá-lo, ele vive uma série de aventuras maravilhosas, a 
primeira das quais dá título ao romance. Caminhando pela floresta, Yvain vê um leão lutando com uma horrível serpente cuspidora de fogo. Após um instante de hesitação sobre qual dos contendores deve auxiliar, o herói opta pelo leão.

Depois de matar o réptil, o cavaleiro prepara-se para enfrentar o felino, que, pensa ele, certamente se voltará para atacá-lo. Mas, em vez disso, movido pela gratidão, o animal demonstra claramente sua submissão, imitando os gestos de um vassalo diante de seu senhor, como lembrou Jean Dufournet. ${ }^{139}$ A partir desse dia, ambos caminharão sempre juntos, tais quais um cão fiel e seu dono, o que valerá a Yvain, que esconde seu verdadeiro nome, o epíteto de Cavaleiro do Leão, o qual, por sua vez, desempenhará uma função capital na obtenção do perdão de Laudine.

Entre as aventuras que se seguem, Yvain enfrenta um gigante, que, depois de ter sequestrado a maioria dos filhos de um nobre, pretende agora apoderar-se dos restantes, inclusive de sua filha, a qual será oferecida como objeto sexual ao mais vil de seus criados. Enfrenta também dois filhos de um diabo, para libertar trezentas mulheres nobres escravizadas, no chamado Castelo da Pior Aventura.

Depois de justar com seu grande amigo Gauvain, sem reconhecê-lo, numa belíssima cena de louvor à amizade, que se resolve favoravelmente aos dois cavaleiros, o herói retorna a Landuc, onde a astuciosa Lunete, valendo-se da dupla identidade Yvain/Cavaleiro do Leão, consegue fazer Laudine receber seu esposo de volta.

\subsection{O maravilhoso em Yvain}

Um de meus centros de interesse em Yvain ou le Chevalier au Lion consiste no maravilhoso. Não se trata aqui do gênero literário definido por Todorov por oposição ao gênero fantástico ${ }^{140}$. Na época de Chrétien, o termo remete a algo diferente, como nos lembra Le Goff, atento à precisão conceitual:

No latim, como nas línguas vernáculas, não havia um termo que designasse uma categoria intelectual, estética, científica ou mental que costumamos chamar de "o maravilhoso". O maravilhoso na literatura

\footnotetext{
${ }^{139}$ DUFOURNET, J. Le Lion d'Yvain. In: Paris: Champion, 1988. p. 82.

${ }^{140}$ TODOROV, T. Introdução à literatura fantástica. $3^{\mathrm{a}}$ ed. São Paulo: Perspectiva, 2008.
} 
não constituía um gênero. Um adjetivo, mirabilis em latim, merveillos em francês antigo (presente na Canção de Rolando, em torno de 1080), ou merveillable, faz a pessoa, o objeto, o fenômeno e, enfim, o substantivo ao qual se reporta, entrar na categoria do maravilhoso. O termo mais importante do campo semântico do maravilhoso é o substantivo feminino merveille, que já é encontrado na Vida de Santo Alexis, por volta de 1050. [...] O plural latino mirabilia ("as maravilhas") pôde ser utilizado, no baixo latim, como um feminino singular ("a maravilha"), mas no latim medieval dos clérigos, erudito, mirabilia é o termo que designa o que nós chamamos "o maravilhoso". Contudo, enquanto nós definimos uma categoria, um tipo de realidade, a Idade Média latina vê um conjunto, uma coleção de seres, fenômenos, objetos, possuindo todos a característica de serem surpreendentes, no sentido forte da expressão, e que podem estar associados quer ao domínio propriamente divino (portanto próximo do milagre), quer ao domínio natural (sendo a natureza originalmente o produto da criação divina), quer ao domínio mágico, diabólico (portanto uma ilusão produzida por Satã e seus seguidores sobrenaturais ou humanos).

O maravilhoso medieval caracteriza-se pela raridade e pelo espanto que suscita, em geral admirativo. Ele afeta primariamente o olhar e implica qualquer coisa de visual, posto que deriva da raiz mir; a mesma que se encontra nos termos latinos miror, mirari ("surpreender-se") e mirus (“surpreendente"). ${ }^{141}$

É nesse sentido - de algo raro, surpreendente e que foge ao ordinário - que utilizarei o termo, inicialmente, neste trabalho.

O maravilhoso sempre chamou minha atenção e ele parecia ser um ponto pelo qual a literatura ulterior dialoga com os textos medievais, como mostra a publicação, em 2006, das atas de um colóquio internacional, realizado em outubro de 2002, sobre as diferentes abordagens da maravilha ao longo dos séculos de literatura francófona, da Idade Média a Émile Ollivier, passando por La Fontaine, Flaubert, Breton e pela tradição oral africana. ${ }^{142}$

Em minhas primeiras leituras das narrativas de Chrétien, Yvain aparecia-me como aquela na qual o maravilhoso mais se evidenciava, excetuando-se Perceval ou le conte du Graal. Mas, neste, tinha inicialmente a impressão de que a maravilha se mostrava mais cristianizada e se revestia de uma atmosfera mística ausente no Chevalier au Lion. ${ }^{143}$ Como, de início, o que despertava mais intensamente meu interesse eram justamente as figuras como os anões, os gigantes, os objetos mágicos, os quais, segundo Le Goff, provêm do paganismo

\footnotetext{
${ }^{141}$ LE GOFF, J. Maravilhoso. In: .; SCHMITT, J.-C. Dicionário temático do Ocidente medieval. São Paulo: EDUSC, 2002. v. 2. p. 106-107. (grifos em negrito meus)

${ }^{142}$ GINGRAS, F. (Dir.). Une étrange constance: les motifs merveilleux dans les littératures d'expression française du Moyen Âge à nos jours. Québec: Les Presses de l’Université Laval, 2006.

143 Trata-se de impressões iniciais que se transformaram no decorrer da pesquisa, mas que contribuíram inicialmente para a realização de um recorte.
} 
bárbaro, mais precisamente das mitologias celta, germânica e escandinava, ${ }^{144}$ confirmei como recorte inicial os limites de Yvain.

\subsubsection{O lugar da maravilha: Yvain e outros textos medievais}

Se, de um lado, percebia mais maravilhas no Chevalier au Lion do que em Érec et Énide, por exemplo, de outro, ao comparar os textos de Chrétien com outras produções do período, tinha a falsa impressão de que a participação do maravilhoso, mesmo em Yvain, era muito pequena. Após algumas releituras, constatei que isso ocorria pelo fato de, nas obras utilizadas para comparação, o maravilhoso ocupar o centro da ação, o núcleo mesmo da história narrada, ao passo que, no texto de Chrétien, as maravilhas pareciam concentrar-se, com raras exceções, nas descrições.

Vejamos. Em A canção dos Nibelungos, por exemplo, além de uma presença muito maior de objetos mágicos, o maravilhoso aparece na caracterização das próprias personagens principais. É o caso da donzela Brünhild, que o rei Gunther pretendia desposar:

A força de Brünhild mostrou-se tremenda. Trouxeram-lhe uma pedra arredondada para o interior do círculo, gigantesca e muito pesada, doze vigorosos guerreiros mal conseguiam carregá-la. Brünhild costumava atirá-la depois de arremessar a lança. Os burgúndios encheram-se de temor. "Misericórdia!", exclamou Hagen. "Que espécie de amante o rei conseguiu! Esta deveria ser a noiva do demônio no inferno!"”145

Nesse mesmo episódio, em que Siegfried ajuda secretamente o rei Gunther a combater/conquistar a donzela, graças a um manto de invisibilidade, a interferência do maravilhoso na ação fica muito evidente: "Siegfried era corajoso, alto e de forte compleição. Atirou mais longe a pedra e saltou a maior distância ainda e, devido às suas artes mágicas, tinha forças suficientes para levar consigo o rei Gunther em seu salto" ${ }^{\text {"146. }}$.

Vê-se, aqui, que o maravilhoso não faz parte apenas do cenário, mas é utilizado para caracterizar personagens principais e o próprio protagonista da primeira parte da Canção, Siegfried. Além disso, o maravilhoso interfere diretamente no curso dos acontecimentos.

${ }^{144}$ LE GOFF, J. Maravilhoso. In: .; SCHMITT, J.-C. Dicionário temático do Ocidente medieval. São Paulo: EDUSC, 2002. v. 2. p. 110.

${ }^{145}$ CANÇÃO dos Nibelungos (A). São Paulo: Martins Fontes, 2001. p. 75.

${ }^{146}$ Ibid., p. 76. (grifo meu) 
Gunther só venceu Brünhild, conquistando o direito de desposá-la, graças à astúcia e às "artes mágicas" de Siegfried.

O mesmo se passa em Mélusine, de Jean d'Arras ${ }^{147}$, em que a própria protagonista, a fada Melusina, é um ser maravilhoso: uma mulher que, uma vez por semana, assume sua verdadeira forma, metade mulher, metade serpente. Nesse dia, seu marido, que não conhece a natureza feérica de sua esposa, é proibido por ela de vê-la e mesmo de procurar saber onde esteve. Depois de muitos anos de felicidade, o marido rompe o acordo e Melusina, ao percebê-lo, voa para longe, sem poder retomar sua forma totalmente humana, e não retorna nunca mais.

Nesse e noutros contos "melusinianos", como o Lai de Lanval, de Marie de France $^{148}$, ou o anônimo do século XIII, La Châtelaine de Vergy ${ }^{149}$, a própria estrutura da narrativa depende do maravilhoso: um mortal encontra uma fada que se torna sua amante e que lhe proporciona riquezas além do imaginável. Essa felicidade durará enquanto ele mantiver segredo sobre o amor de ambos. Desrespeitado o interdito, perde-se o amor da fada e as riquezas que o acompanhavam. Mais uma vez, o maravilhoso ocupa o centro da ação.

Nos lais, sejam os de Marie de France, sejam os anônimos dos séculos XII e XIII, o maravilhoso também se faz fortemente presente. Bisclavret ${ }^{150}$ tem como protagonista um lobisomem! Em Yonec ${ }^{151}$, da mesma autora, vemos uma bela mulher, enclausurada no alto de uma torre por seu marido ciumento, ser visitada por um pássaro que se transforma num belo cavaleiro e se torna seu amante. Percebe-se que a ação praticamente se confunde com a maravilha.

Não há como resumir Yonec ou Mélusine sem que apareça o maravilhoso. Já a intriga de Yvain pode ser resumida do seguinte modo: Um cavaleiro fere outro mortalmente em combate singular e torna-se senhor de suas terras ao casar-se com a viúva. Um dia, pede a sua esposa que lhe permita se ausentar por um tempo para retomar seus feitos de armas e aumentar seu renome, sua glória. Ela concede-lhe o prazo de um ano, ao fim do qual, se ele não retornar, tudo estará terminado entre eles. Como nos contos de estrutura melusiniana, a simples enunciação do interdito já nos faz prever que ele será desobedecido. A segunda parte do romance mostra-nos as aventuras vividas pelo protagonista antes de conquistar o perdão de sua dama.

\footnotetext{
147 JEAN D’ARRAS. Mélusine ou la noble histoire de Lusignan. Paris: Le Livre de Poche, 2003.

${ }^{148}$ MARIE DE FRANCE. Le lai de Lanval. Paris: Le Livre de Poche, 1995.

${ }^{149}$ CHÂTELAINE de Vergy (La). Paris: Gallimard, 1994.

${ }^{150}$ MARIE DE FRANCE. Bisclavret. In: Lais. Paris: Gallimard, 2002. p.147-165.

${ }^{151}$ MARIE DE FRANCE. Yonec. In: op. cit., p. 223-255
} 
Evidentemente, toda a graça, todo o encanto do poema foram suprimidos nesse resumo. Mas ele não é falso; é perfeitamente correto. Isso já mostra que, em Yvain, o maravilhoso não ocupa o centro da intriga. Em alguns momentos, ele chega a interferir nela, mas, de modo geral, concentra-se no cenário ou se restringe às personagens secundárias.

\subsubsection{Maravilhas descritivas}

Afirmar que, em Yvain, o maravilhoso não interfere nunca na intriga consistiria num exagero. Afinal, dois objetos mágicos salvam o herói em momentos decisivos: o anel da invisibilidade, sem o qual ele teria sido linchado logo no início da narrativa ${ }^{152}$, e o unguento oferecido pela fada Morgana, que põe fim à sua loucura ${ }^{153}$. Entretanto, as maravilhas que se destacam na narrativa aparecem como descrições. Uma delas é a fonte de Landuc. Trata-se, antes de mais nada, de um cenário, ricamente descrito:

["]Mes se tu voloies aler Ci pres jusqu'a une fontainne, N'en revandroies pas sanz painne, Se tu li randoies son droit. Ci pres troveras orendroit Un santier qui la te manra. Tote la droite voie va, Se bien viax tes pas anploier, Que tost porroies desvoier: Il i a d'autres voies mout. La fontainne verras qui bout, S'est ele plus froide que marbres. Onbre li fet li plus biax arbres $C$ 'onques poïst former Nature. En toz tens sa fuelle li dure, Qu'il ne la pert por nul iver. Et s'i pant uns bacins de fer A une si longue chaainne Qui dure jusqu'an la fontainne. Lez la fontainne troverras Un perron, tel con tu verras; Je ne te sai a dire quel, Que je n'en vi onques nul tel; Et d'autre part une chapele Petite, mes ele est mout bele.
["]Mas se quisesse ir Até uma fonte próxima Não retornaria sem dificuldade Se lhe restituísse seu direito. Perto daqui, logo encontrará Uma trilha que o conduzirá até lá. Siga sempre em frente, Se quiser empregar bem seus passos, Pois logo poderia se desgarrar: Há muitos outros caminhos. Verá a fonte que ferve, Apesar de mais fria que o mármore. Faz-lhe sombra a mais bela árvore Que jamais Natureza pôde formar. Todo tempo dura-lhe a folhagem, Que não perde em nenhum inverno. Dela pende uma bacia de ferro Presa a uma corrente tão longa Que chega até a fonte. Junto à fonte encontrará Uma pedra, tal qual a verá; Não sei dizer-lhe qual, Pois nunca vi igual; E, do outro lado, uma capela Pequenina, mas muito bela.

${ }^{152}$ Versos 1021-1251.

${ }^{153}$ Versos 2948-3007. 
S'au bacin viax de l'eve prandre

Et desus le perron espandre,

$L a$ verras une tel tanpeste

Qu'an cest bois ne ramanra beste,

Chevriax ne cers, ne dains ne pors,

Nes li oisel s'an istront fors;

Car tu verras si foudroier,

Vanter, et arbres peçoier,

Plovoir, toner et espartir,

Que, se tu t'an puez departir

Sanz grant enui et sanz pesance,

Tu seras de meillor cheance

Que chevaliers qui i fust onques."

Del vilain me parti adonques,

Que bien m'ot la voie mostree.

Espoir si fu tierce passee,

Et pot estre pres de midi,

Quant l'arbre et la fontainne vi.

Bien sai de l'arbre, c'est la fins,

Que ce estoit li plus biax pins

Qui onques sor terre creüst.

Ne cuit c'onques si fort pleüst

Que d'eve i passast une gote,

Einçois coloit par desor tote.

A l'arbre vi le bacin pandre,

Del plus fin or qui fust a vandre

Encor onques en nule foire.

De la fontainne, pöez croire,

Qu'ele boloit com iaue chaude.

Li perrons ert d'une esmeraude

Perciee ausi com une boz,

Et s'a quatre rubiz desoz,

Plus flanboianz et plus vermauz

Que n'est au matin li solauz,

Quant il apert en oriant;

Ja, que je sache a esciant,

$\mathrm{Ne}$ vos an mantirai de mot.

La mervoille a veoir me plot

De la tanpeste et de l'orage,

Don je ne me ting mie a sage,

Que volentiers m'an repantisse

Tot maintenant, se je poïsse,

Quant je oi le perron crosé

De l'eve au bacin arosé.

Mes trop en i verssai, ce dot;

Que lors vi le ciel si derot

Que de plus de quatorze partz

Me feroit es ialz li esparz;

Et les nues tot mesle mesle

Gitoient pluie, noif et gresle.

Tant fu li tans pesmes et forz

Que cent foiz cuidai estre morz
Se quiser pegar água com a bacia

E sobre a pedra derramá-la,

Verá tal tempestade

Que nesse bosque não restará bicho,

Cabrito nem cervo, nem gamo nem javali,

E mesmo os pássaros dele fugirão;

Pois você verá caírem raios,

Ventar, árvores serem destruídas,

Chover, trovejar e relampejar tanto

Que, se puder escapar

Sem grande pena e sem sofrimento,

Terá melhor sorte

Que qualquer cavaleiro que lá já esteve".

Deixei então o vilão

Que bem me mostrara o caminho.

Acho que passara a hora de terça ${ }^{154}$,

Sendo talvez cerca de meio-dia,

Quando avistei a árvore e a fonte.

Quanto à árvore, tenho certeza de

Que era o mais belo pinheiro

Que jamais cresceu sobre a terra.

Nunca, creio, por mais que chovesse,

Uma gota d'água poderia atravessá-lo.

Antes, escorreria por cima.

Vi pendendo da árvore a bacia,

Do mais fino ouro jamais vendido

Em nenhuma feira.

Quanto à fonte, podem crer,

Borbulhava como água quente.

A pedra era uma esmeralda

Oca como um tonel

E apoiada sobre quatro rubis,

Mais flamejantes e vermelhos

Que o sol da manhã,

Quando desponta no Oriente.

Agora, pelo que sei com certeza,

Não lhes mentirei numa só palavra.

Agradou-me ver a maravilha

Da tempestade e da tormenta

E por isso não me tomo por sábio,

Pois de bom grado teria me arrependido

Logo em seguida, se possível,

De a pedra côncava

Ter regado com a água da bacia.

Derramei em demasia, certamente,

Pois logo vi o céu tão agitado

Que de mais de quatorze pontos

Os relâmpagos me feriam os olhos.

E as nuvens, de tropel,

Arremessavam chuva, neve e granizo.

Tão ruim e forte foi a tempestade

Que cem vezes pensei ter morrido

${ }^{154}$ Trata-se das horas canônicas: matinas (0h), laudes (3h), prima (6h), terça (9h), sexta (12h), nona (15h), vésperas (18h) e completas (21h). 
Des foudres qu'antor moi cheoient, Et des arbres qui peceoient.

Sachiez que mout fui esmaiez,

Tant que li tans fu rapaiez.

Mes Dex tost me rasegura

Que li tans gaires ne dura,

Et tuit li vant se reposerent;

Des que Deu plot, vanter n'oserent.

Et quant je vis l'air cler et pur,

De joie fui toz asseür;

Que joie, s'onques la conui,

Fet tost oblier grant enui.

Des que li tans fu trespassez

Vi sor le pin toz amassez.

Oisiax, s'est qui croire le vuelle,

Qu'il n'i paroit branche ne fuelle,

Que tot ne fust covert d'oisiax;

$S$ 'an estoit li arbres plus biax.

Doucemant li oisel chantoient,

Si que mout bien s'antr'acordoient;

Et divers chanz chantoit chascuns;

$C$ 'onques ce que chantoit li uns

A l'autre chanter ne oï.

De lor joie me resjoï;

$S$ 'escoutai tant qu'il orent fet

Lor servise trestot a tret;

Que mes n'oï si bele joie

Ne ja ne cuit que nus hom l'oie,

Se il ne va oür celi

Qui tant me plot et abeli

Que je m'an dui por fol tenir.

Tant i fui que j'oï venir

Chevaliers, ce me fu avis;

Bien cuidai que il fussent dis,

Tel noise et tel bruit demenoit

Uns seus chevaliers qui venoit. ${ }^{155}$
Pelos raios que à minha volta caíam

E pelas árvores que se despedaçavam.

Saibam que fiquei horrorizado

Enquanto o tempo não se abrandou.

Mas Deus logo me tranquilizou,

Pois a tempestade não durou muito

E os ventos todos se acalmaram:

Assim que Deus o quis, ventar não ousaram.

E quando vi o ar claro e puro,

De alegria sosseguei,

Pois a alegria experimentada

Logo oblitera os grandes aborrecimentos.

Assim que terminou a tempestade,

$\mathrm{Vi}$, amontoados sobre o pinheiro,

Tantos pássaros, creiam se quiserem,

Que não aparecia ramo nem folha

Que deles não estivesse coberto,

$\mathrm{O}$ que embelezou ainda mais a árvore.

Os pássaros cantavam docemente,

Harmonizando-se muito bem,

Entoando cada qual um canto diferente.

$\mathrm{O}$ que um cantava

Eu não ouvia o outro cantar.

Alegrei-me com sua alegria.

Escutei-os até

O fim de seu ofício.

Jamais ouvira tão bela manifestação de alegria e

Creio que ninguém pode ouvir,

A menos que ouça essa,

Que me agradou tanto

Que pensei estar enlouquecendo.

Assim permaneci até ouvir aproximar-se

Um cavaleiro, como me pareceu.

Inicialmente, pensei que fossem dez,

Tamanho o barulho produzido

Pelo único cavaleiro que vinha.

O efeito da manipulação dessa maravilha por alguém é uma modificação na paisagem, que nos é apresentada sob a forma de uma nova descrição. Na sintaxe da narrativa, o episódio da fonte está na origem dos acontecimentos, é verdade. Afinal, após o fim da tempestade e o concerto dos pássaros, um grande cavaleiro, o senhor daquelas terras, aparece, e o causador da tempestade tem sorte se sair vivo do combate. E é desse encontro que nasce a aventura de Yvain. No entanto, deve-se destacar que a fonte é palco da luta entre o herói e o senhor de Landuc. Ainda que se possa dizer que a fonte funciona também como motor da luta, esta, uma vez começada, depende apenas da destreza dos combatentes, não sofrendo nenhuma intervenção de caráter sobrenatural. Dito de outro modo, nesse caso, a manipulação da

\footnotetext{
${ }^{155}$ Versos 368-480.
} 
maravilha não tem outra finalidade senão o prazer/horror da contemplação por parte das personagens.

Três exemplos contrastivos podem clarear a questão, dois deles extraídos da própria obra de Chrétien. Conforme vimos, quando Siegfried uliliza o manto da invisibilidade na Canção dos Nibelungos, ele tem como objetivo ajudar Gunther a se casar com Brünhild, o que só seria possível se o rei a vencesse naquela prova. Do mesmo modo, em Yvain, quando a donzela utiliza o unguento, ela visa à recuperação do herói e quando este se serve do anel da invisibilidade, ele pretende escapar àqueles que pretendem aniquilá-lo. Assim, nesses casos, do ponto de vista das personagens, a maravilha tem uma finalidade prática. Já no caso da fonte, despejar água sobre a esmeralda não serve, em princípio, para nada. Aqueles que o fazem pretendem apenas observar um fenômeno espantoso. E, em Yvain ou le Chevalier au Lion, é esse tipo de maravilha sem finalidade prática, do ponto de vista das personagens, que se destaca.

Vejamos o episódio em que Yvain conhece o Leão:

Messire Yvains pansis chemine

Par une parfonde gaudine

Tant qu'il oï enmi le gaut

Un cri mout dolereus et haut.

Si s'adreça lors vers le cri

Cele part ou il l'ot oï,

$E t$, quant il parvint cele part,

Vit un lyon, en un essart,

Et un serpant qui le tenoit

Par la coe, et si li ardoit

Trestoz les rains de flame ardant.

$N$ 'ala mie mout regardant

Messire Yvains cele mervoille;

A lui meïsmes se consoille

Auquel d'aus deus il aidera.

Lors dit qu'au lyon se tanra,

Qu'a venimeus ne a felon

Ne doit an feire se mal non,

Et li serpanz est venimeus,

Si li saut par la boche feus,

Tant est de felenie plains.

Por ce panse messire Yvains

Qu'il l'ocirra premieremant.

S'espee tret et vint avant

Et met l'escu devant sa face,

Que la flame mal ne li face

Que il gitoit parmi la gole,

Qui plus estoit lee d'une ole.

Se li lyons aprés l'asaut,

La bataille pas ne li faut,
Monsenhor Yvain caminhava pensativo

Em meio a densa vegetação

Quando ouviu do meio da floresta

Um grito muito alto e doloroso.

Avançou então na direção do grito

Até o trecho de onde o ouvira

E, lá chegando,

Viu um leão, num roçado,

E uma serpente que o prendia

Pela cauda e queimava-lhe

Os flancos com chamas ardentes.

Não permaneceu muito tempo olhando

Monsenhor Yvain essa maravilha;

A si mesmo pergunta

A qual dos dois ajudará.

Então, pende para o leão,

Pois a criatura venenosa e traiçoeira

Não se deve fazer senão mal.

Ora, a serpente é venenosa

E chega a soltar fogo pela boca

Tamanha a sua perfídia.

Por isso, Monsenhor Yvain decide

Matá-la primeiramente.

Desembainha a espada e avança,

Põe o escudo diante do rosto,

Para que não o atinja a chama

Que a serpente lançava pela boca

Que era mais larga que um caldeirão.

Se em seguida o leão o atacar,

Yvain não faltará à luta, 
Mes que qu'il l'en aveingne aprés,

Eidier li voldra il adés,

Que pitiez li semont et prie

Qu'il face secors et aïe

A la beste gentil et franche. ${ }^{156}$
Mas, haja o que houver depois,

Ajudá-lo é o que quer agora,

Pois Piedade o convoca e pede

Que socorra e ajude

$\mathrm{O}$ animal valente e nobre.

No centro dessa cena, temos uma ação (luta), a qual, por sua vez, provoca uma reação no herói. No entanto, estamos diante da descrição de uma ação. ${ }^{157}$ Aqui, a maravilha — o combate entre um leão e uma cobra que expele fogo pela boca - é um espetáculo que se oferece ao olhar; afinal, diz-se que, atraído pelo grito do leão, Yvain viu os dois animais em disputa. E o texto não se limita a narrar a sucessão das reações do cavaleiro, mas descreve também seus pensamentos. Além disso, o narrador baseia a decisão do herói de auxiliar o leão sobre uma descrição das características dos dois animais. Evidencia-se, portanto, o caráter predominantemente descritivo dessa cena. E, embora essa passagem desempenhe uma função na economia da obra - pois é nela que se cria o vínculo que engendrará o codinome do protagonista -, no plano mais imediato da história, trata-se, mais uma vez, de uma maravilha que não visa a um determinado fim, como ocorreria com um objeto mágico, mas que simplesmente existe e se revela ao olhar.

O próprio episódio do Castelo da Pior Aventura - cujo ponto culminante é o combate entre Yvain e duas criaturas demoníacas e que poderia, de início, ser percebido como um trecho essencialmente narrativo - , é longamente preparado por meio de descrições: num primeiro momento, descreve-se fisicamente o grupo de trezentas mulheres; após o relato da origem de sua situação, descrevem-se a natureza servil e as condições degradantes do trabalho a que são submetidas; finalmente, descreve-se a hospitalidade dos senhores do castelo com relação ao herói, que passa a noite com eles, antes de enfrentar os filhos de um diabo. ${ }^{158}$ Assim, esse castelo se situa no centro de um episódio, mas como palco de suas ações. Novamente, não se trata da manipulação de uma maravilha para se atingir um fim.

Portanto, como vimos, as maravilhas presentes em Yvain apresentam-se sobretudo sob a forma de descrições. Trata-se de uma observação bastante interessante, se lembrarmos que, para Le Goff, o maravilhoso implica algo de visual, atingindo primordialmente o olhar. Ora, ao descrever-nos algo, o autor nos faz visualizá-lo. ${ }^{159}$ Assim, essa impressão de que as

\footnotetext{
${ }^{156}$ Versos 3343-3377.

${ }^{157}$ Essa simples formulação já denuncia a deficiência da tradicional oposição entre o narrativo como a instância da ação, de um lado, e o descritivo como ausência de ação, de outro.

${ }^{158}$ Versos 5109-5449.

${ }^{159}$ Pelo menos, é nisso que geralmente tendemos a acreditar. Veremos adiante que se trata de mais do que isso.
} 
maravilhas em Yvain localizam-se sobretudo nas descrições vem ao encontro da própria definição de maravilhoso.

\subsection{O recorte: uns vileins, qui resanbloit Mor}

De todos os trechos descritivos de Yvain, o que mais despertou meu interesse foi aquele no qual Calogrenant descreve seu encontro com o vilão, no sentido de "homem da villa", o domínio agrícola:

L'ostel gaires esloignié n'oi, Qant je trovai, en uns essarz, Tors salvages com lieparz, Qui s'antreconbatoient tuit Et demenoient si grant bruit Et tel fierté et tel orguel, Se voir conuistre vos an vuel, $C$ 'une piece me treis arriere Que nule beste n'est tant fiere Ne plus orguelleuse de tor. Uns vileins, qui resanbloit Mor, Leiz et hideus a desmesure, Einsi tres leide criature Qu'an ne porroit dire de boche Assis s'estoit sor une çoche, Une grant maçue en sa main. Je m'aprochai vers le vilain, Si vi qu'il ot grosse la teste Plus que roncins ne autre beste, Chevox mechiez et front pelé, S'ot pres de deus espanz de lé Oroilles mossues et granz Autiex com a uns olifanz, Les sorcix granz et le vis plat, Ialz de çuete, et nes de chat, Boche fandue come lous, Danz de sengler aguz et rous, Barbe rosse, grenons tortiz, Et le manton aers au piz, Longue eschine torte et boçue ; Apoiez fu sor sa maçue, Vestuz de robe si estrange Qu'il n'i avoit ne lin ne lange, Einz ot a son col atachiez Deus cuirs de novel escorchiez, Ou de deus tors ou de deus bués.
Não me tinha afastado muito de minha hospedagem, Quando encontrei, num roçado,

Touros selvagens como leopardos, Que se enfrentavam todos E produziam tão grande barulho E demonstravam tanto furor e tanta audácia Que, se querem saber a verdade, Recuei por um momento, Pois nenhum animal é mais selvagem Nem mais vigoroso que o touro. Um vilão, que parecia um mouro, Demasiadamente feio e medonho, Criatura tão feia Que não se poderia descrever, Estava sentado sobre uma cepa, Com uma grande maça na mão. Aproximei-me do vilão E vi que tinha a cabeça maior Que a de um rocim ou outro animal, Os cabelos desgrenhados e a testa calva, Com cerca de dois palmos de largura, As orelhas peludas e grandes Como as de um elefante, As sobrancelhas grandes e o rosto achatado, Olhos de coruja e nariz de gato, A boca fendida como a de um lobo, Dentes de javali, afiados e alaranjados, Uma barba ruiva, bigodes retorcidos, E o queixo pegado ao peito, A coluna longa, torta e corcunda. Estava apoiado em sua maça, Vestido com uma roupa muito estranha, Nem de linho, nem de lã, Tinha antes amarradas ao pescoço Duas peles recém-extraídas Ou de touros ou de bois. 
An piez sailli li vilains, lués

Qu'il me vit vers lui aprochier.

Ne sai s'il me voloit tochier,

Ne ne sai qu'il voloit enprendre,

Mes je me garni de desfandre,

Tant que je vi que il estut

En piez toz coiz, ne ne se mut,

Et fu montez desor un tronc,

S'ot bien dis et set piez de lonc;

Si m'esgarda, ne mot ne dist,

Ne plus c'une beste feïst,

Et je cuidai qu'il ne seüst

Parler, ne reison point n'eüst.

Tote voie tant $m$ 'anhardi,

Que je li dis: "Va, car me di

Se tu es boene chose ou non!"

Et il me dist: "Je sui uns hon.

- Quiex hom iés tu? - Tex con tu voiz;

Si ne sui autres nule foiz.

- Que fez tu ci? - Ge m'i estois,

Et gart les bestes de cest bois.

- Gardes? Par saint Pere de Rome,

Ja ne conuissent eles home;

Ne cuit qu'an plain ne an boschage

Puisse an garder beste sauvage,

N'en autre leu, por nule chose,

S'ele n'est liee et anclose.

- Je gart si cestes et justis

Que ja n'istront de cest porpris.

- Et tu comant? Di m'an le voir!

- N'i a celi qui s'ost movoir

Des que ele me voit venir,

Car quant j'en puis une tenir,

Si l'estraing si par les deus corz,

As poinz que j'ai et durs et forz,

Que les autres de peor tranblent

Et tot environ moi s'asanblent,

Ausi con por merci crïer;

Ne nus ne s'i porroit fier,

Fors moi, s'antr'eles s'estoit mis,

Qu'il ne fust maintenant ocis.

Einsi sui de mes bestes sire,

Et tu me redevroies dire
$\mathrm{O}$ vilão ficou em pé, logo

Que me viu aproximar-me.

Não sei se queria me fazer algum mal,

Nem o que pretendia,

Mas fiquei pronto para me defender,

Até ver que ele permanecia

Em pé, calmo, imóvel,

Sobre um tronco

De dezessete pés de comprimento. ${ }^{160}$

Olhou-me, mas não pronunciou uma só palavra,

Não mais do que o faria um bicho,

$\mathrm{O}$ que me fez pensar que não soubesse

Falar e que não fosse dotado de razão.

Todavia, encorajei-me

A ponto de dizer-lhe: - Vamos, diga-me lá

Se você é uma boa criatura ${ }^{161}$ ou não!

E ele me respondeu: - Sou um homem.

- Que homem é você? - Do tipo que está vendo,

Nunca sou outro.

- Que faz aqui? - Fico parado

E guardo os animais deste bosque.

- Guarda? Por São Pedro de Roma,

Eles não conhecem o homem;

Não creio que numa planície ou num pequeno bosque

Possa-se manter um animal selvagem,

Nem noutro lugar, por nada desse mundo,

Se ele não estiver amarrado ou confinado.

- Eu, no entanto, guardo-os e tão bem

Que nunca sairão deste domínio.

- E como o faz? Diga-me a verdade!

- Não há um que ouse se mover

Assim que me vê chegar,

Pois, quando agarro um,

Seguro-o com tanta força pelos chifres,

Com meus punhos firmes e fortes,

Que os demais tremem de medo

E se reúnem todos à minha volta,

Assim como quem pede clemência.

Ninguém poderia assegurar-se,

Exceto eu, de, estando entre eles,

Não ser morto imediatamente.

Assim, sou senhor de meus animais.

Sua vez de me dizer

${ }^{160}$ Philippe Walter interpreta que dezessete pés é a altura do camponês, o que vê como um "traço evidente de gigantismo", já que a personagem mediria cerca de cinco metros. (CHRÉTIEN DE TROYES. Oeuvres complètes. Paris: Gallimard, 1994. p. 1194, nota 3 referente à p. 346). Outros tradutores consideram essa medida relativa ao tronco. Não encontrei nenhuma menção a lonc como podendo se referir a altura, mas sim remetendo às noções de espaço, de comprimento ou de distância. No entanto, Michel Rousse traduz como Walter. Assim, deixo registradas aqui as duas interpretações.

161 "Chose", em francês antigo, pode significar "coisa", "pessoa" ou "criatura". Esta me parece, no caso, a tradução mais apropriada por constituir uma espécie de meio-termo entre as demais. De fato, a personagem é apresentada como um vilão e, portanto, representa uma pessoa. Mas a aparência desse ser é tão extraordinária que se poderia mesmo duvidar de sua humanidade. Calogrenant chega a pensar que ele não possui linguagem nem inteligência. Assim, "criatura" parece um vocábulo adequado por ir além do estatuto de coisa e por ficar aquém do estatuto de humano. 
Quiex hom tu iés, et que tu quiers.

- Je sui, ce voiz, uns chevaliers

Qui quier ce que trover ne puis;

Assez ai quis, et rien ne truis.

- Et que voldroies tu trover?

- Avanture, por esprover

Ma proesce et mon hardemant.

Or te pri et quier et demant,

Se tu sez, que tu me consoille

Ou d'aventure ou de mervoille

- A ce, fet il, faudras tu bien:

D'aventure ne sai je rien,

$N$ 'onques mes n'en oï parler.

Mes se tu voloies aler

Ci pres jusqu'a une fontainne,

$N$ 'en revandroies pas sanz painne,

Se tu li randoies son droit.",162
Que homem é você e o que busca.

- Sou, como vê, um cavaleiro

Que busca o que não pode encontrar.

Muito procurei e nada encontrei.

- E o que gostaria de encontrar?

- Aventura, para pôr à prova

Meu valor e minha coragem.

Agora suplico, reclamo e espero,

Caso conheça, que me aconselhe

Uma aventura ou uma maravilha.

- Isso, disse, vai lhe faltar.

De aventura nada sei,

Nunca ouvi falar.

Mas se quisesse ir

Até uma fonte próxima

Não retornaria sem dificuldade

Se lhe restituísse seu direito.

Esse trecho chama a atenção pelo caráter inusitado dessa figura bestial. Até então, a narrativa se passara no quadro da realidade cotidiana. Além disso, o narrador parecia contido, como mostra seu desejo de economia no verso 250: "Del soper vos dirai briemant" ("Sobre o jantar, falarei a vocês brevemente”). Portanto, impossível não se espantar duplamente: no plano da matéria, com a intrusão de uma personagem absolutamente incomum; no plano da expressão, com o acúmulo de comparações animais, fazendo desse camponês praticamente uma criatura compósita, digna das narrativas mitológicas da Antiguidade clássica ou do Oriente.

Essa passagem surpreende ainda mais pelo fato de outras personagens muitíssimo mais importantes que o vilão não serem tão ricamente descritas. Por que dedicar-se tanto à descrição de uma personagem anônima que aparece apenas no início do romance, desaparecendo definitivamente logo em seguida?

Tomado por esse estranhamento, resolvi adotar como recorte esse retrato, não apenas para melhor compreender sua função na economia geral da obra, mas também na expectativa de que ele me permitisse investigar as relações entre o maravilhoso e o descritivo.

A primeira menção a esse homem selvagem, dentro do romance, ocorre no relato supracitado de Calogrenant. Nele, o guardador de touros indica ao cavaleiro a aventura da fonte, não se limitando a descrevê-la, mas fornecendo mesmo o que Baumgartner chamou suas "instruções de uso" "163. Mas, antes mesmo que a personagem entre em cena pela primeira

\footnotetext{
${ }^{162}$ Versos 276-371.

163 BAUMGARTNER, E. La fontaine au pin. In: DUFOURNET, J. (Org.). Le Chevalier au Lion: approches d'un chef-d'oeuvre. Paris: Champion, 1988. p. 37.
} 
vez, o vocábulo "vilão" já aparece, o que não é desprovido de significação, como veremos a seguir.

Yvain ou le Chevalier au Lion inicia-se com um procedimento emprestado aos antigos: um prólogo indireto ${ }^{164}$. Nele, ao desfazer do presente e enaltecer o tempo passado, segundo uma tópica também antiga, o narrador recorre a um provérbio ${ }^{165}$ e diz: "Car mout valt mialz, ce m'est avis, / Uns cortois morz c'uns vilains vis" ${ }^{166}$. A carga negativa assumida por "vilão" por oposição a "cortês" é evidente.

O vocábulo reaparece numa reprimenda - portanto, também num sentido negativo dirigida pela rainha Guenièvre ao maledicente Keu: “Enuieus estes, et vilains, / De tancier a voz conpaignons"167. "Vilão" aparece aqui como adjetivo, assim como, em sua primeira ocorrência, vinha sob a forma de um adjetivo substantivado. Já no episódio escolhido como

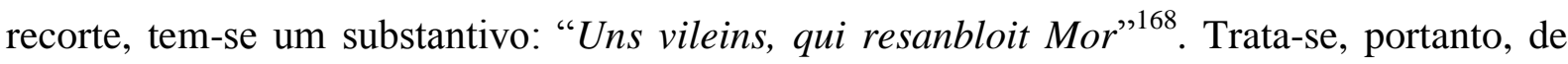
empregos diferentes de uma mesma palavra. Apesar disso, o uso do adjetivo de forma negativa nos dois casos mencionados lança luzes sobre a concepção do substantivo "vilão": este não significa simplesmente "camponês"; ele não é neutro. Ao contrário, vem carregado de um preconceito acerca do que seja um camponês.

Assim, ao inserir aqui e ali o vocábulo "vilão", antes mesmo que a personagem do guardador de touros entre em cena pela primeira vez, Chrétien cria um interessante jogo de referências: na primeira ocorrência do substantivo "vilão" — já designando nossa personagem —, toda a carga negativa veiculada pelo adjetivo "vilão"— que já aparecera duas vezes - é imediatamente projetada sobre a figura do camponês. Disso resulta que, a partir da simples menção vileins no verso 286, o público passa a esperar algo de ruim desse encontro.

A imagem negativa que os homens do século XII produzem dos vilões é comentada por Sylvie Lefèvre:

Homme de la villa ("domaine agricole"), le vilain a vu son image de paysan se déprécier par rapport à la figure de l'homme de cour ou courtois, le noble et le chevalier. [...] Dans l'acquisition de traits moraux péjoratifs,

\footnotetext{
${ }^{164}$ JAMES-RAOUL, D. Chrétien de Troyes, la griffe d'un style. Paris: Honoré Champion, 2007. p. 172.

${ }^{165} \mathrm{Se}$, para nós, modernos, provérbios evocam a banalidade do senso comum e, portanto, combinam pouco com a poesia elevada, as artes poéticas dos séculos XII e XIII os veem como ornamentos de estilo e consideram-nos uma boa maneira de iniciar um poema. Chrétien os utiliza bastante em Yvain, mas também em seus outros romances. A aversão que sentimos pelos provérbios já se verificava no século XVII, no qual eram vistos como típicos da linguagem burguesa e popular. (FRAPPIER, J. Étude sur Yvain ou le Chevalier au Lion de Chrétien de Troyes. Paris: SEDES, 1969. p. 222-224; FARAL, E. Les arts poétiques du XII et du XIII siècle. Genève: Slatkine, 1982. p. 58-60.

${ }^{166}$ Versos 31-32: "Pois mais vale, em minha opinião, um cortês morto que um vilão vivo".

${ }^{167}$ Versos 90-91: "Sois desagradável e vilão por insultardes vossos companheiros".

${ }^{168}$ Verso 286: "Um vilão, que parecia um mouro,".
} 
l'homophonie partielle avec l'adjectif vil a pu également jouer. Le plus souvent, l'adjectif vilain est utilisé comme terme d'injure. Et lorsqu'un paysan est décrit en détail, il prend facilement des allures d'homme sauvage, voire de bête. ${ }^{169}$

Pensemos no poema de Chrétien à luz desse comentário. Vimos o adjetivo "vilão" ser utilizado como termo de injúria e vimos também, no relato de Calogrenant, o boieiro ser representado como um selvagem, mais bicho que homem. Mas a autora menciona ainda "traços morais pejorativos". O nosso poema, entretanto, apresenta uma prosopografia do vilão e não uma etopeia, isto é, ele explicita apenas as características físicas da personagem e não o seu caráter. Este, no entanto, aparece como sugestão para o público do século XII.

Vincent Jouve mostra a importância das dimensões extra e intratextual na percepção da personagem de qualquer romance por parte do leitor. Ao compor uma imagem mental da personagem retratada, o leitor recorre a seu saber enciclopédico, que inclui não apenas conhecimentos sobre as pessoas que habitam o mundo real, mas também sobre outras personagens de outros textos, entendendo aqui "texto" em seu sentido amplo de sistema de signos verbais ou não verbais. Enfim, "Le personnage ne se réduit pas à ce que le roman nous dit de lui." 170

Vejamos alguns componentes dessa "enciclopédia" dos homens do século XII que nos ajudam a redesenhar o horizonte de expectativas desse público diante da descrição do camponês. Um bom começo consiste em verificar as diferentes acepções da palavra "vilão" em francês antigo: "vilain n.m. et adj. (XI ${ }^{\mathrm{e}}$ s.; lat. villanum, habitant de la villa, domaine rural). 1. Paysan, manant, homme de basse condition. -2. adj. Laid moralement (Wace). -3. Laid physiquement (G. de Dole)"171.

A contiguidade das acepções 2 e 3 remete-nos à associação, presente na época de Chrétien, entre beleza e virtude, de um lado, e entre feiura e vício, de outro. Umberto Eco assinala a origem antiga dessa correspondência:

\footnotetext{
169 LEFÈVRE, S. Répertoire. In: CHRÉTIEN DE TROYES. Oeuvres complètes. Paris: Gallimard, 1994 (Bibliothèque de la Pléiade). p. 1512: "Homem da villa ('domínio agrícola'), o vilão viu sua imagem de camponês se depreciar em relação à figura do homem de corte ou cortês, o nobre e o cavaleiro. [...] Na aquisição de traços morais pejorativos, a homofonia parcial com o adjetivo vil pôde igualmente desempenhar um papel. Na maioria das vezes, o adjetivo vilain é utilizado como termo de injúria. E, quando um camponês é descrito em detalhes, ele toma facilmente a aparência de homem selvagem, e mesmo de bicho". (grifos em negrito meus)

${ }^{170}$ JOUVE, V. L'effet-personnage dans le roman. $2^{\mathrm{e}}$ ed. Paris: P.U.F., 2008. p. 48: “A personagem não se reduz àquilo que o romance nos diz dela".

${ }^{171}$ GREIMAS, A. J. (Ed.). Dictionnaire de l'ancien français. Paris: Larousse, 2001: "vilão s.m. e adj. (s. $\mathrm{XI}$; lat. villanum, habitante da villa, domínio rural). 1. Camponês; habitante de burgo ou aldeia, plebeu submetido à justiça senhorial; homem de baixa condição. -2. adj. Feio moralmente (Wace). -3. Feio fisicamente (G. de Dole)."
} 
"O ideal grego da perfeição era representado pela kallokagathia, termo que nasce da união de kállos (genericamente traduzido como ‘belo') e agathós (termo usualmente traduzido como 'bom', mas que cobre toda uma série de valores positivos). Observou-se que a virtude de ser kalos e agathós definia genericamente aquilo que corresponderia, no mundo anglo-saxônico, à noção aristocrática de gentleman, pessoa de aspecto digno, de coragem, estilo, habilidade e conclamadas virtudes esportivas, militares e morais. À luz desse ideal, o helenismo elaborou uma vasta literatura sobre a relação entre feiura física e feiura moral."

Um exemplo, mencionado na própria antologia de Eco, é o Livro III d'A República, de Platão, no qual se lê: “- E a feiura, a arritmia, a desarmonia são irmãs da má linguagem e do mau-caráter, ao passo que as qualidades opostas são irmãs e imitações do caráter oposto, da sabedoria e da bondade de alma"173.

Sabendo-se que a associação Belo/Bom ainda é válida no século XII, não é descabido pensar que, inversamente, ao descrever o vilão como um ser de aparência horrenda, o narrador sugere também uma feiura moral.

Vejamos o que a segunda referência ao guardador de touros selvagens pode acrescentar a essa reflexão. Ela se dá quando Yvain — decidido a ver com seus próprios olhos as maravilhas mencionadas e a vingar a desonra do primo - traça mentalmente as etapas de sua jornada:

Puis verra les tors et l'essart Et le grant vilain qui les garde. Li veoirs li demore et tarde. Del vilain qui tant par est lez, Granz, et hideus, et contrefez, Et noirs a guise de ferron ${ }^{174}$
Então verá os touros e o roçado, E o grande vilão que os guarda.
Anseia por vê-lo, Esse vilão tão feio, Grande e horrendo e disforme E negro como um ferreiro

Essa segunda descrição é muito mais concentrada. Não há mais adjetivos caracterizando os touros e não há referências a seu comportamento. O primeiro verso desse trecho (v. 706) resume nada menos que dez da primeira descrição feita por Calogrenant. Nele, temos apenas a marca de enumeração "puis", o verbo "ver"175, cujo sujeito está oculto por meio da omissão do pronome pessoal (mais comum em francês antigo que em francês moderno), e os substantivos "touros" e "roçado", precedidos por artigos definidos. Estes,

\footnotetext{
${ }^{172}$ ECO, U. (Org.). História da feiura. Rio de Janeiro: Record, 2007. p. 23.

${ }^{173}$ Ibid., p. 33.

${ }^{174}$ Versos 706-711.

175 Fundamental, pois o vilão é também uma maravilha e, como vimos, as maravilhas apresentam-se primordialmente ao sentido da visão.
} 
como em francês moderno, indicam que não se trata de qualquer roçado nem de quaisquer touros. Eles remetem a algo já referido anteriormente no texto e de cuja existência o público já está ciente.

Dos 39 versos da rica descrição do vilão feita por Calogrenant, restam apenas as referências a seu gigantismo, a sua extrema feiura e a sua atividade (guardar os touros), condensadas em nada mais que 6 versos. Mas, se o detalhamento desaparece, há uma insistência em dois pontos: seu tamanho e sua feiura. Insiste-se sobre o primeiro duas vezes ("grant", v. 707, e "granz", v. 710) e, sobre o segundo, quatro vezes: "lez" (v. 709), "hideus" e "contrefez" (v. 710), e "noirs a guise de ferron" (v. 711), considerando-se que a negritude consiste, no Ocidente do século XII, numa tópica do feio.

Assim, se, nessa segunda ocorrência, trata-se apenas de uma retomada do essencial, constatamos primeiramente que dele faz parte a personagem do boieiro, pois Yvain não sonha apenas com a fonte, mas deseja ardentemente encontrar essa criatura. Em segundo lugar, percebemos que o fundamental daquilo que o vilão transmite é dado por sua feiura, mais ainda que por seu gigantismo, embora este faça parte daquela. Yvain quer encontrar o vilão, não para que ele o guie em direção à fonte, mas pelo simples (des)prazer de vê-lo, de presenciar a maravilha que é esse homem horrendo.

Interessante observar que há aqui a inserção de um elemento novo. Ora, num resumo, num balanço, não se acrescentam informações novas. Isso faz com que esse segundo trecho seja importante, não apenas por rememorar um elemento anterior da narrativa, ${ }^{176}$ mas sobretudo por acrescentar-lhe algo. E o novo elemento não é insignificante.

Observando os textos antologiados e os documentos iconográficos reproduzidos por Umberto Eco em sua História da feiura, constatamos que os diabos são comumente representados negros e/ou com traços animalescos (figuras 1 e 2).

\footnotetext{
${ }^{176}$ Estratégia útil no contexto medieval de escuta de uma leitura em voz alta (sem que se tenha o texto sob os olhos para acompanhá-la) e fragmentada em sessões.
} 


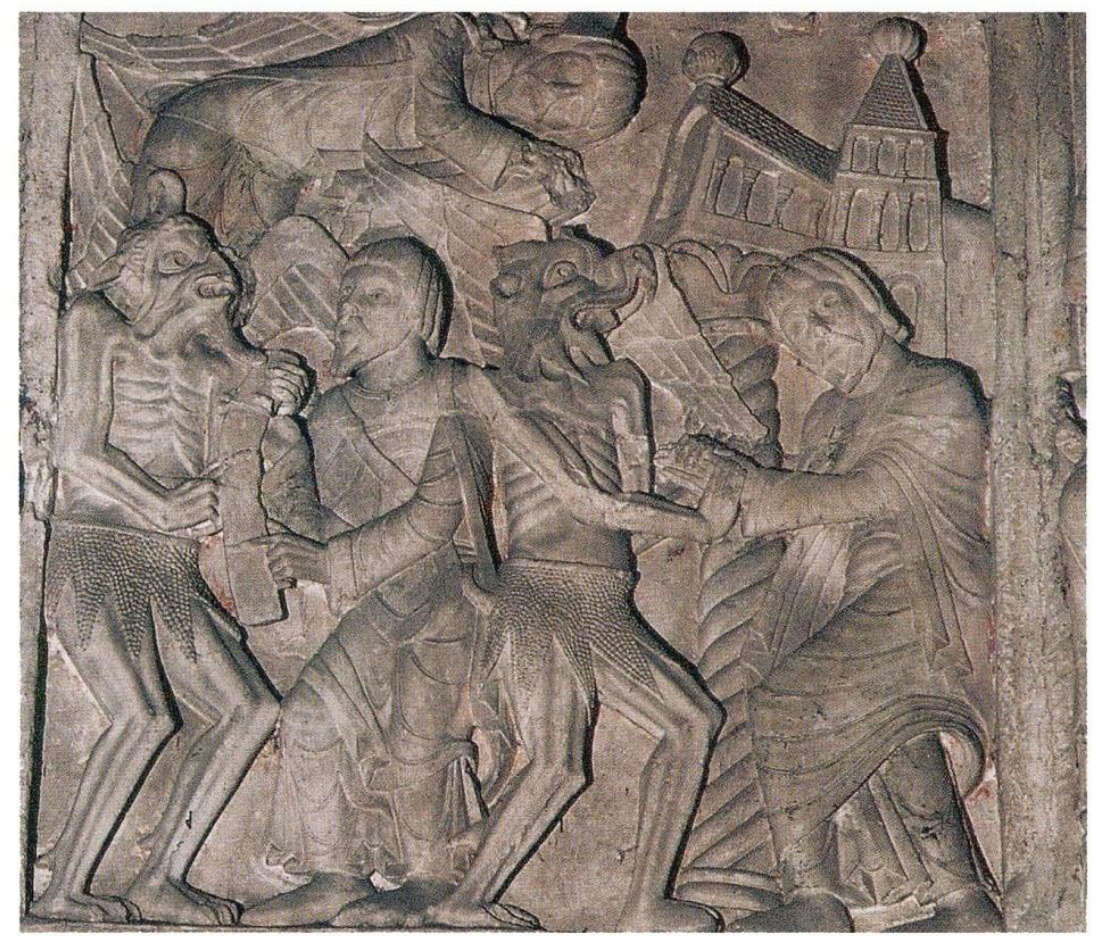

Figura 1 - O padre Teófilo faz um pacto com o diabo, séc. XII, Tímpano de Souillac. ${ }^{177}$

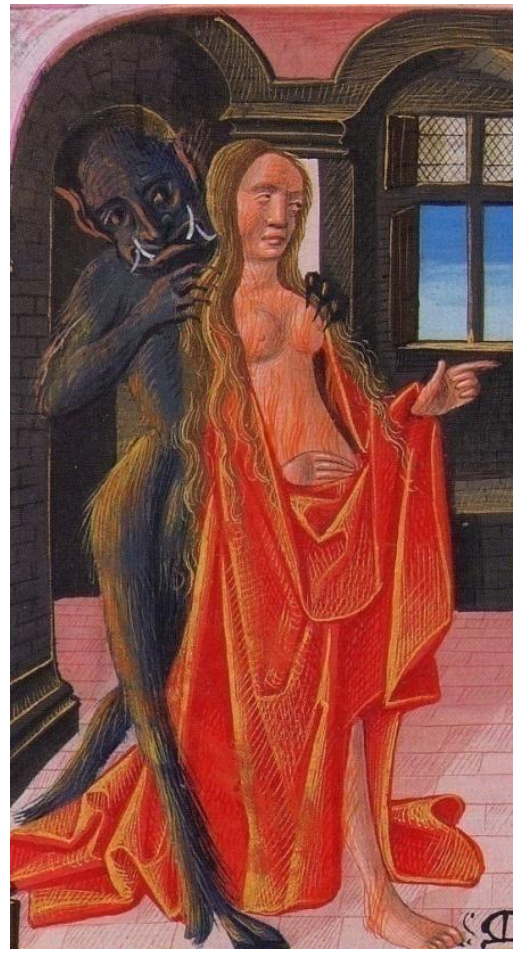

Figura 2 - Jacques Le Grant. Le livre des bonnes moeurs, ms. 297, f. 109v., séc. XV, Chantilly/Musée Condé. ${ }^{178}$ (detalhe)

\footnotetext{
${ }^{177}$ ECO, U. (Org.). História da feiura. Rio de Janeiro: Record, 2007. p. 93.

${ }^{178}$ Ibid., p. 94.
} 
Assim, na pintura e na escultura da Idade Média, bem como em sua "literatura", a negritude é marca do diabólico, que, em Yvain, é projetada sobre o vilão. Os dois filhos de um diabo, contra os quais Yvain luta no Castelo da Pior Aventura, são também descritos como "hideus et noir"179.

Vejamos algumas citações do artigo no qual Jérôme Baschet comenta as representações do diabo entre os séculos IX e XV:

Note-se que o Diabo está quase totalmente ausente das imagens cristãs até o século IX. É somente por volta do ano 1000 que encontra uma posição digna dele, quando se desenvolve uma representação específica enfatizando sua monstruosidade e animalidade, e manifestando seu poder hostil de modo cada vez mais insistente. ${ }^{180}$

Embora decaídos, os diabos mantêm a mesma natureza dos anjos. São, portanto, seres incorpóreos, de corpo etéreo, o que não os impede de se manifestarem aos homens sob as mais diversas aparências. Sua própria natureza tende à diversidade $\mathrm{e}$ às metamorfoses que os tornam imperceptíveis e perigosos. Os relatos medievais estão cheios de manifestações do Diabo em forma animal (serpente, dragão, mosca, vespa, pássaro negro, gato...). [...] Nas aparições relatadas pelos monges, como Raul Glaber (1048) ou Guiberto de Nogent (1115), o Diabo assume aparência humana mas inquietante: é pequeno e feio, macilento e corcunda, vestido de modo sórdido, às vezes "negro como um etiope". A partir do século XI, desenvolve-se uma iconografia específica do Diabo: seu corpo conserva uma silhueta antropomórfica, mas essa forma, feita por Deus 'à sua imagem', é pervertida, tornada monstruosa pela deformidade e pelo acréscimo de características animais (goela, presas, chifres, orelhas pontudas, asas de morcego, e a partir do século XIII, cauda, corpo peludo, garras de ave....). ${ }^{181}$

Embora pudesse ser representado pequeno, como vimos acima, o diabo também poderia ser figurado em proporções agigantadas, como a do nosso vilão que, em algumas traduções, atinge cinco metros.

Algumas vezes desde o século XII, mas sobretudo nos séculos XIV e XV, desenvolve-se uma verdadeira iconografia da majestade de Satã que destaca a autoridade dele por meio de uma estatura gigantesca, de sua posição frontal e sentada, das insígnias do poder (trono, cetro, coroa) e da ordem que impõe à corte de demônios. ${ }^{182}$

\footnotetext{
${ }^{179}$ Verso 5514: "horrendos e negros".

180 BASCHET, J. Diabo. In: LE GOFF, J.; SCHMITT, J.-C. (Coord.). Dicionário temático do Ocidente medieval. São Paulo: EDUSC, 2002. v. 1. p. 319. (grifos meus)

${ }^{181}$ Ibid., p. 322. (grifos meus)

182 Ibid., p. 330. (grifo meu)
} 
Ao ler os inúmeros trechos destacados, temos a nítida impressão de que eles descrevem o guardador de touros. Essas coincidências eram percebidas pelo público do século XII, que, num contexto de intensa religiosidade, estava familiarizado com representações do diabo, presentes, por exemplo, nas catedrais. Considerando o estudo de Vincent Jouve, podemos pensar que esse conjunto de representações age diretamente no processo de (re)composição da personagem do vilão durante a "recepção"183.

Para o público do século XII, a aparência de uma personagem ainda é um indício da posição que ela assumirá em relação ao herói: antagonista ou auxiliar. A extrema feiura do vilão deixa Calogrenant apreensivo e, juntamente com ele, os ouvintes, que provavelmente esperam da personagem uma atitude tão terrível quanto sua aparência. A tensão da cena é explicitada na fala de Calogrenant:

An piez sailli li vilains, lués Qu'il me vit vers lui aprochier

Ne sai s'il me voloit tochier, Ne ne sai qu'il voloit enprendre, Mes je me garni de desfandre, Tant que je vi que il estut En piez toz coiz, ne ne se mut, Et fu montez desor un tronc, S'ot bien dis et set piez de lonc; Si m'esgarda, ne mot ne dist, Ne plus c'une beste feïst, Et je cuidai qu'il ne seüst Parler, ne reison point n'eüst. Tote voie tant $m$ 'anhardi, Que je li dis: "Va, car me di Se tu es boene chose ou non!" 184
O vilão ficou em pé, logo

Que me viu aproximar-me.

Não sei se queria me fazer algum mal, Nem o que pretendia, Mas fiquei pronto para me defender, Até ver que ele permanecia Em pé, calmo, imóvel, Sobre um tronco De dezessete pés de comprimento. Olhou-me, mas não pronunciou uma só palavra, Não mais do que o faria um bicho, $\mathrm{O}$ que me fez pensar que não soubesse Falar e que não fosse dotado de razão.

Todavia, encorajei-me

A ponto de dizer-lhe: - Vamos, diga-me lá Se você é uma boa criatura ou não!

O cavaleiro chega a duvidar da humanidade do camponês, ao perguntar-lhe se era uma boa criatura ou não. O suspense é mantido pelas respostas enigmáticas do vilão. No entanto, ele não age com hostilidade. Ao contrário, responde polidamente às questões do cavaleiro, revela-lhe a existência de uma maravilha e ainda lhe indica o caminho e o modo como deve proceder. Assim, contrariando todas as expectativas, ele desempenha a função de um guia, ou seja, de um auxiliar.

\footnotetext{
${ }^{183}$ Jean Rohou lamenta a conotação passiva que a tradução "recepção" assume. Segundo ele, por meio do termo alemão, Jauss se refere a uma consciência reflexiva que se apropria ativamente de algo. Assim, ele preferiria utilizar actualisation ou mise en fonctionnement. (ROHOU, J. L'histoire littéraire. Paris: Nathan, 1996. p. 87.) Manterei o uso consagrado "recepção", mas entre aspas, numa tentativa de lembrar a precariedade da tradução, apontada por Rohou. ${ }^{184}$ Versos 312-327.
} 
Vejamos o que ocorre quando Yvain finalmente encontra o vilão - terceira e última referência a essa personagem em todo o romance:

Et vint es essarz l'andemain,

Si vit les tors et le vilain

Qui la voie li anseingna;

Mes plus de cent foiz se seingna

De la mervoille que il ot,

Comant Nature feire sot

Oevre si leide et si vilainne. ${ }^{185}$
Foi ao roçado no dia seguinte

E viu os touros e o vilão,

Que lhe ensinou o caminho.

Mas, mais de cem vezes, fez o sinal da cruz,

Tamanho o seu espanto.

Como Natureza pôde realizar

Obra tão feia e tão desagradável?

Na altura em que Yvain chega ao roçado, o público já sabe que o vilão não se mostrara hostil em relação a Calogrenant e, portanto, pode também não o ser em relação ao herói. Mas o texto mantém a ambiguidade, insistindo em seu papel de guia e, ao mesmo tempo, em seu aspecto potencialmente maligno. $\mathrm{O}$ ato de persignar-se é importante aqui, pois reforça a impressão por parte dos ouvintes de estarem diante de uma manifestação diabólica. Jérôme Baschet, ao abordar os gestos humanos que mantêm o Diabo sob controle, define o sinal da cruz como "um gesto de poder infalível, que salva de todos os perigos" "186. Monique Santucci, por sua vez, lembra que um eremita, vendo Yvain louco e nu, foge, mas "— point à remarquer — [...] il ne se signe pas à sa vue, comme s'il était devant le diable"187. Lembra também que, além de Yvain diante do vilão, a donzela que encontra o próprio herói desacordado e nu na floresta, também faz o sinal da cruz: "Tous deux croient avoir affaire à une incarnation de Satan"188.

O mais interessante é que esses dois aspectos foram postos lado a lado na construção do poema. O verso que realça a função de guia do vilão é imediatamente seguido por outro em que Yvain se persigna, "como se estivesse diante do diabo". Mais ainda, esse verso se inicia por um "mas"! Não seria absurdo pensarmos que, na performance, o intérprete tivesse a opção de aumentar a sugestão de que algo terrível poderia acontecer, acentuando a conjunção adversativa e efetuando uma pausa prolongada logo em seguida: "Viu os touros e o vilão, que lhe ensinou o caminho, maaas...".

\footnotetext{
${ }^{185}$ Versos 791-797. (grifos em negrito meus)

186 BASCHET, J. Diabo. In: LE GOFF, J.; SCHMITT, J.-C. (Coord.). Dicionário temático do Ocidente medieval. São Paulo: EDUSC, 2002. v. 1. p. 326.

187 SANTUCCI, M. La folie dans le Chevalier au Lion. In: DUFOURNET, J. (Org.). Le Chevalier au Lion: approches d'un chef-d'oeuvre. Paris: Champion, 1988. p. 161: “— ponto a destacar — [...] ele não se persigna ao vê-lo, como se estivesse diante do diabo". (grifo meu)

${ }^{188}$ Ibid., p. 163: "Ambos creem estar perante uma encarnação de Satã".
} 


\subsubsection{Funções}

Depois desse breve comentário acerca da figura do vilão, já é possível perceber suas funções no poema.

Primeiramente, o vilão desempenha uma função de guia. Na arquitetura da narrativa, era indispensável que Calogrenant encontrasse uma personagem dotada de inteligência e de fala para lhe explicar o funcionamento da fonte maravilhosa. Se o cavaleiro tivesse chegado a ela casualmente, em sua errância, sem encontrar o vilão, o que justificaria que ele tivesse a ideia de se servir da bacia de ouro pendurada ao pinheiro para recolher água da fonte e despejá-la sobre a esmeralda? Sem dúvida, ele poderia se maravilhar com essa pedra preciosa, com os rubis que a sustentam, com o ouro da bacia, com o fato de a água borbulhar ainda que fria. Mas o espetáculo da tempestade e do subsequente canto dos pássaros não seria presenciado, pois, para acioná-lo, é necessário proceder a uma espécie de ritual. E é esse ritual que o guardador de touros ensina ao cavaleiro. Note-se que as instruções vêm sob a forma de uma descrição, a qual, por sua vez, engendrará uma nova descrição em outro momento da narrativa.

A segunda função da personagem é marcar uma transição. Ela mostra que não estamos mais nos domínios de Arthur. Antes de encontrar o vilão, Calogrenant se hospedara no castelo de um vavassalo, isto é, o vassalo de um vassalo, após ter cavalgado pela floresta de Broceliande. Depois de ter sido derrotado por Esclados o Ruivo, protetor da fonte, retorna para mais um pernoite junto ao vavassalo, o qual, futuramente, abrigará também Yvain. Considerando-se apenas o nível da história ${ }^{189}$, pode-se dizer que, nos trechos relativos à estada dos cavaleiros nesse castelo, não acontece rigorosamente nada. No entanto, eles possuem uma função importante para o todo e essa função se relaciona àquela do vilão. Vejamos.

Quando Calogrenant chega pela primeira vez ao castelo do vavassalo, este demonstra grande felicidade, pois afirma já fazer tanto tempo que hospedou um cavaleiro em seu senhorio que ele nem mesmo é capaz de se lembrar exatamente quando o fez pela última vez. Isso sugere que a terra em que se abriga Calogrenant se situa a grande distância do mundo

\footnotetext{
${ }^{189}$ Adoto neste trabalho as noções de história, enredo e discurso tais quais expostas por Umberto Eco no segundo capítulo de Seis passeios pelos bosques da ficção, a saber: história, como a sequência de eventos ordenados cronologicamente; enredo, como o modo pelo qual a história é efetivamente narrada, com suas inversões temporais e digressões; e discurso, como parte da estratégia narrativa do autor-modelo. (ECO, U. Os bosques de Loisy. In: Seis passeios pelos bosques da ficção. São Paulo: Companhia das Letras, 2006. p. 33-53.)
} 
conhecido e dominado pelo rei Arthur. Essa impressão é confirmada pela seguinte passagem, na qual já é Yvain quem parte em busca da fonte:

Messire Yvains ne sejorna,

Puis qu'armez fu, ne tant ne quant, Einçois erra, chascun jor, tant

Par montaignes et par valees, Et par forez longues et lees, Par leus estranges et salvages, Et passa mainz felons passages, Et maint peril et maint destroit, Tant qu'il vint au santier estroit Plain de ronces et d'oscurté; ${ }^{190}$
Monsenhor Yvain não descansou -

Desde que foi armado - um só instante.

Antes errou, dia após dia, durante muito tempo,

Por montanhas e vales,

Por extensas florestas,

Por lugares estranhos e selvagens,

Passando por muitos caminhos traiçoeiros, Muitos perigos e muitas dificuldades,

Até que chegou à estreita trilha,

Espinhosa e escura.

Trata-se da narrativa do percurso de Yvain até chegar ao castelo do vavassalo. Percebe-se o quanto ele cavalgou e quantas paisagens diferentes e - talvez o mais importante - estranhas ${ }^{191}$ atravessou. Assim, ainda que as passagens que descrevem a estada de Calogrenant no castelo do vavassalo - antes e depois da aventura da fonte ${ }^{192}$ - não determinem acontecimentos futuros, elas têm a importante função de criar um ambiente para os eventos principais: o encontro com o vilão e a chegada a Landuc. Que tipo de ambiente? Um ambiente misterioso, em razão da distância ${ }^{193}$ percorrida e da estranheza da paisagem, que culminará num roçado no qual uma figura monstruosa pastoreia touros selvagens como se fossem domésticos e numa fonte maravilhosa que desencadeia tempestades! ${ }^{194}$

\footnotetext{
${ }^{190}$ Versos 758-767. (grifos em negrito meus)

${ }^{191}$ No dicionário de Greimas, vemos quatro acepções para o vocábulo estrange: 1. "Étranger", que pode significar "estranho" ou "desconhecido", como Philippe Walter o traduziu; 2. "Que pertence a um outro"; 3. "Inospitaleiro", 4. "Esquisito". [GREIMAS, A. J. (Ed.). Dictionnaire de l'ancien français. Paris: Larousse, 2001.] Seja como for, cada uma dessas acepções implica uma ideia de alteridade, aquilo que não faz parte do meu mundo, mas do mundo do Outro e que, portanto, não me é familiar.

192 Apenas Calogrenant, tendo fracassado em sua aventura, retorna ao castelo do vavassalo. Yvain, bemsucedido, permanece nas terras de Laudine como seu novo senhor.

${ }^{193}$ Zumthor afirma que a maioria dos homens da Idade Média, ao final de suas vidas, nunca terá deixado suas aldeias! (ZUMTHOR, P. La mesure du monde. Paris: Seuil, 1993. p. 74.) Se considerarmos que a experiência de vida do público interfere em sua "recepção" do poema, a informação fornecida por Zumthor nos permite avaliar o quanto a distância percorrida por Calogrenant e, mais tarde, por Yvain, poderia tocar os ouvintes do século XII.

${ }^{194}$ Afasto-me, portanto, dos críticos que consideram o encontro com o homem selvagem um episódio risível. Embora reconheça a existência de vários momentos de humor em Yvain ou le Chevalier au Lion, julgo que o tom da passagem em questão é grave, determinado não apenas pelos inúmeros elementos mencionados no tópico anterior, como também pela apreensão dos cavaleiros diante da situação. Ora, num romance cortês, o medo do herói - modelo de conduta - não gera risos e sim suspense no público! Para uma visão contrária à minha, consultar: MÉNARD, P. Rires et sourires dans le roman du Chevalier au Lion. In: DUFOURNET, J. (Org.). Le Chevalier au Lion: approches d'un chef-d'oeuvre. Paris: Champion, 1988. p. 7-29; ECO, U. (Org.). História da feiura. Rio de Janeiro: Record, 2007. p. 138. Embora não comente o poema de Chrétien, Eco situa a passagem do boieiro no tópico de sua antologia relativo às sátiras sobre o vilão e às festas carnavalescas ao lado de textos nitidamente destinados ao riso, como "O peido do aldeão", de Rutebeuf, do século XIII. Ora, fora de seu contexto, o episódio do vilão de Yvain pode provocar riso no público moderno, mas o tom do poema de Chrétien difere radicalmente daquele do poema de Rutebeuf.
} 
Um exemplo simples, extraído de nossa vida cotidiana, ajuda-nos a perceber o efeito provocado pelas partes relativas ao castelo do vavassalo. Na apreciação de um quadro, a moldura é importante, não podendo ser suprimida sem alterar nossa percepção do todo. Assim, uma moldura vermelha tenderá a ressaltar tons avermelhados da pintura. No entanto, a primeira importa apenas como elemento valorizador da segunda, esta sim, a principal. Do mesmo modo, as passagens em questão, ao emoldurar os trechos concernentes ao vilão e à fonte, funcionam como intensificadores de maravilhas que se revelam em crescendo. $\mathrm{O}$ castelo do vavassalo situa-se próximo ao roçado dos touros, o qual, por sua vez, não dista da fonte. Assim, se a fonte de Landuc corresponde ao Outro Mundo, como já afirmaram muitos críticos, o castelo consistiria em sua antessala.

Mas por que "crescendo"? Porque a passagem relativa ao vavassalo gera um clima de suspense e expectativa, que aumenta progressivamente, em proporção direta à introdução de maravilhas. Durante a permanência de Calogrenant no castelo do vavassalo, não se vê nenhum objeto, ser ou fenômeno maravilhoso. Já no episódio do vilão, o maravilhoso se concentra na figura do boieiro. Finalmente, na aventura mais esperada, a da fonte da tormenta, há uma explosão de elementos maravilhosos: a descrição de cada um dos elementos que compõem a paisagem, a tempestade, o canto dos pássaros, a aproximação de um único cavaleiro que produz o barulho de dez!

Afirmei que o episódio da acolhida de Calogrenant pelo vavassalo cria uma expectativa. Vejamos como se dá a produção desse efeito.

Dois elementos provocam no público a nítida impressão de que algo está para acontecer. Um deles é a insistência com que o vavassalo bendiz o caminho que conduzira Calogrenant até ele: mais de sete vezes seguidas! Diante dessa amplificação, que acentua o contentamento do anfitrião, o público familiarizado com os romances corteses logo imagina que o senhor da fortaleza é atingido por profundas aflições e, por isso, necessita do auxílio de um cavaleiro. Esses versos (203-206, reproduzidos logo adiante) parecem sugerir um grande alívio por parte do vavassalo, o que nos faz sentir uma atmosfera quase messiânica, como se Calogrenant fosse o predestinado a libertá-lo de um grande mal. Sabemos, no entanto, que a satisfação do desejo por aventuras por parte do cavaleiro, assim como do público, não se efetivará nesse castelo, devendo ser postergada.

O outro elemento se dá no plano da composição. Os bons contadores de histórias nos fazem esquecer nossa presença física numa performance e provocam-nos a sensação de que estamos escondidinhos em algum ponto da cena narrada, observando tudo com nossos próprios olhos. Evidentemente, trata-se de uma grande ilusão e nós só vemos, ou melhor, 
pensamos ver, aquilo que o contador nos oferece. Dito de outro modo: o narrador não nos permite ver tudo; ele seleciona o que deve ser apresentado e escolhe a melhor forma fazê-lo. Assim, o tempo de uma história raramente coincide com o tempo de sua narração ou de sua leitura. ${ }^{195}$ Vejamos o que acontece com o relato de Calogrenant:

Il m'avint plus a de set anz Que je, seus come païsanz, Aloie querant aventures, Armez de totes armeüres Si come chevaliers doit estre; Et tornai mon chemin a destre Parmi une forest espesse. Mout i ot voie felenesse, De ronces et d'espines plainne; A quelqu'enui, a quelque painne, Ting cele voie et ce santier. A bien pres tot le jor antier M'en alai chevalchant issi, Tant que de la forest issi, Et ce fu en Broceliande. De la forest, en une lande Entrai, et vi une bretesche A demie liue galesche; Se tant $i$ ot, plus n'i ot pas. Cele part ving plus que le pas, Vi le baille et le fossé Tot anviron parfont et lé, Et sor le pont an piez estoit, Cil cui la forteresce estoit, Sor son poing un ostor müé. Ne l'oi mie bien salüé, Quant il me vint a l'estrié prendre, Si me comanda a descendre. Je descendi, qu'il n'i ot el, Car mestier avoie d'ostel; Et il me dist tot maintenant Plus de set foiz en un tenant, Que beneoite fust la voie Par ou leanz entrez estoie. ${ }^{196}$
Há mais de sete anos,

Só como um camponês, Partia eu em busca de aventuras, Completamente armado, Como convém a um cavaleiro. Tomei um caminho a minha direita, Através de espessa floresta. Havia muitos caminhos traiçoeiros, Cheios de sarças e de espinheiros. Com algum penar e alguma dificuldade, Persisti por essa via, por essa trilha, Quase o dia todo.

Assim cavalgava, Até que saí da floresta De Broceliande.

Da floresta, numa charneca Entrei, e vi uma guarita A meia légua gaulesa, Se tanto; não mais que isso. A ela dirigi-me rapidamente. $\mathrm{Vi}$ as muralhas e o fosso Circundante: profundo e largo. Sobre a ponte, em pé, estava O senhor da fortaleza, Empunhando um rapineiro que trocara suas penas. Mal o cumprimentei, Veio segurar-me o estribo E pediu-me que apeasse. Obedeci - não havia opção Pois precisava de alojamento. Imediatamente, ele me disse, Mais de sete vezes seguidas Que bendito era o caminho Pelo qual lá chegara.

Percebe-se que o período de quase um dia inteiro de viagem - até o ponto em que avista o castelo - é resumido em apenas quinze versos. O narrador-personagem afirma ter cavalgado todo esse tempo e menciona sua dificuldade em relação ao caminho, que

\footnotetext{
195 Sobre essa questão, ver ECO, U. Divagando pelo bosque. In: São Paulo: Companhia das Letras, 2006. p. 55-79.

${ }^{196}$ Versos 173-206.
} Seis passeios pelos bosques da ficção. 
caracteriza em poucas palavras. Já o período de apenas uma noite, passada na fortaleza, estende-se pelo espaço da página ${ }^{197}$. Por que isso acontece?

O narrador, ao utilizar poucos versos para apresentar de forma sucinta seu dia, está dizendo que em sua jornada não ocorreu nada que merecesse ser contado. Ora, a partir do momento em que esse mesmo narrador começa a descrever um pouco mais detalhadamente o pátio do castelo, a donzela que o desarma, o manto com que ela o recobre, enfim, a acolhida que recebe por parte de senhores e serviçais, o leitor/ouvinte tem a nítida impressão de que essa atenção concedida pelo narrador ao domínio do vavassalo se deve ao fato de que ele, narrador, considera essa passagem importante, pois, certamente, algo aí deve ter acontecido, contrariamente ao dia de cavalgada.

Ora, Chrétien frustra essa expectativa. Ele conduz a narrativa, por intermédio de sua personagem, de tal modo que esperamos algo de surpreendente quase a cada verso, até chegar o jantar. A partir daí, o narrador volta a resumir — já vimos como ele se recusa a descrever a refeição - e a cena esfria até chegar o momento da partida. O público, familiarizado com os pares "Érec e Énide”, “Cligès e Fénice”, "Lancelot e Guenièvre”, chega a pensar que a filha do castelão é a mocinha do romance, e dedica-lhe um olhar mais atento. No entanto, na manhã seguinte, ela deixa a narrativa definitivamente.

Afirmei acima que o episódio do vavassalo, ao emoldurar aquele do vilão, destaca-o. Isso se dá de dois modos. Por um lado, como foi dito, por meio da criação de uma expectativa que será ampliada com a entrada do vilão em cena. Por outro, por meio de contraste. Vimos que o castelo do vavassalo se situa a grande distância dos domínios de Arthur. Apesar disso, não há nada nele que não se assemelhe à realidade de um nobre daquele tempo. Essa presença de elementos da vida cotidiana do século XII no âmago da ficção confere-lhe um forte efeito de real e estimula a identificação por parte do público. ${ }^{198}$ Mas, sobretudo, ela acentua contrastivamente o caráter maravilhoso da descrição do vilão, situada na cena imediatamente seguinte. Ou seja, a longa distância e as paisagens estranhas percorridas por Calogrenant sugerem um afastamento do mundo já conhecido e dominado, mas o texto, impedindo a concretização das expectativas do público, nada introduz no episódio do castelo. É a partir do

\footnotetext{
${ }^{197}$ São setenta e nove versos que descrevem a chegada de Calogrenant, como vimos, mas ainda: o pátio; a reação dos empregados, que se apressam em se encarregar de seu cavalo; a acolhida por parte da filha do vavassalo, que o desarma e veste; a vestimenta que lhe é oferecida e o prazer de Calogrenant em ficar sozinho com a jovem. Do jantar, limita-se a dizer que foi de seu agrado. A recusa em descrever a refeição é bem explícita, como já vimos. Calogrenant menciona então a conversa com o castelão. Este afirma não ter recebido cavaleiros há muito tempo e pede a seu hóspede que o visite novamente, no caminho de volta de sua aventura. Finalmente, num único verso, resume que foi muito bem hospedado durante a noite.

${ }^{198}$ JAMES-RAOUL, D. Chrétien de Troyes, la griffe d'un style. Paris: Honoré Champion, 2007. p. 411.
} 
encontro com uma criatura monstruosa que se tem a certeza de estar nos limites de um outro mundo.

A terceira função do episódio do vilão já foi parcialmente comentada juntamente com a segunda, uma vez que se relacionam. Trata-se da criação de suspense. Já vimos, no tópico anterior, que o retrato do vilão contém elementos de elevado poder sugestivo do diabólico e o quanto isso pode produzir suspense, já que o público, espelhando as sensações da própria personagem do cavaleiro, passa a esperar que qualquer coisa de terrível aconteça de um momento a outro. No entanto, Chrétien parece romper aqui com a associação entre Belo e Bom, ao atribuir a uma personagem monstruosa a função de adjuvante.

Ao considerar que a figura do vilão gera suspense por suas características potencialmente diabólicas, situamo-nos primordialmente no plano da história, mas o suspense também se produz no plano da composição. Digo "primordialmente" porque a separação entre ambos é artificial, visto ser impossível encontrar um único trecho da história que não seja fruto de uma estratégia narrativa, de um cuidado com a composição. Assim, o que estou dizendo é que o suspense não é gerado apenas por um dado da história (o vilão tem a aparência de um diabo), mas por uma astúcia de Chrétien na construção de seu texto, como veremos a seguir.

Segundo Danièle James-Raoul, a introdução de personagens anônimas é uma novidade ainda não generalizada no último quarto do século XII, mas que será desenvolvida por Chrétien de Troyes. ${ }^{199}$ Uma das funções desse tipo de personagem é manter a atenção do público. Num primeiro momento, apresentam-se, no dizer da autora, como "bexigas narrativas" que podem posteriormente ser enchidas ou não. Quando são introduzidas, nada as distingue das personagens mais importantes, as quais, muitas vezes, mantêm-se anônimas por muitos versos. Basta lembrar que só conheceremos o nome do protagonista de Le Chevalier de la Charrette pouco depois da metade do romance! Os nomes de Laudine e Lunete, importantíssimas em Le Chevalier au Lion, também só serão mencionados tardiamente. Sobretudo no início da leitura, essa impossibilidade de distinguir protagonistas de personagens de segundo ou mesmo de terceiro plano cria suspense, pois o público não sabe se a personagem recém-introduzida desempenhará um papel importante ou não. Os ouvintes podem investir sua atenção mais numa personagem que noutra, já que não conhecem ainda o

\footnotetext{
199 JAMES-RAOUL, D. Chrétien de Troyes, la griffe d'un style. Paris: Honoré Champion, 2007. p. 350. Sobre essa questão, ver também JAMES-RAOUL, D. L'anonymat définitif des personnages et l'avènement du roman: l'apport de Chrétien de Troyes. In: CONNOCHIE-BOURGNE, C. (Org.). Façonner son personnage au Moyen Âge. Aix-en-Provence: P.U.P., 2007. p. 135-144.
} 
desenvolvimento da narrativa. Apenas à medida que esta avança podemos identificar quais personagens merecem maior atenção. ${ }^{200}$

Assim, o vilão, introduzido logo no início do poema, apresenta-se para o público como uma possibilidade narrativa. De fato, como vimos, essa personagem será retomada mais duas vezes, ainda no início do romance, mas não será desenvolvida e desaparecerá em seguida. No entanto, não é apenas como um fio textual a ser explorado que o vilão atrai o olhar do leitor, mas, sobretudo, pela força de sua descrição. Chegamos, finalmente, à quarta função dessa personagem: maravilhar o público.

Umberto Eco afirma que, assim como nos sentimos atraídos pelos animais exóticos de um jardim zoológico, os medievais interessavam-se bastante por criaturas monstruosas. Prova disso é o fato de São Bernardo, em sua Apologia a Guilherme, condenar as abundantes representações de monstros nas igrejas, o que, segundo ele, distrairia os fiéis, desviando-os do principal: a lei de Deus. ${ }^{201}$ Assim, a representação do vilão atende ao gosto do público contemporâneo à produção do poema.

Mas, e quanto a nós, leitores do século XXI? O que, nessa personagem, pode nos interessar ainda hoje? Embora nos cerquemos de novos monstros, como afirma Eco, nossa relação com eles é diferente. ${ }^{202}$ Assim, para além de um relativo interesse pelo exótico que possamos manter, o que de fato nos atrai no retrato do vilão é algo a que os ouvintes do século XII também não eram insensíveis: sua beleza.

Como é possível evocar a simples ideia de beleza a propósito da descrição de um ser com tais características? Trata-se de distinguir, com Eco, entre o feio em si e o feio artístico, que é um feio formal ${ }^{203}$ :

E, falando de feio artístico, é bom lembrar que quase todas as teorias estéticas, pelo menos da Grécia aos nossos dias, têm reconhecido que qualquer forma de feiura pode ser redimida por uma representação artística fiel e eficaz. Aristóteles (Poética, 1448b) fala da possibilidade de realizar o belo imitando com mestria aquilo que é repelente e Plutarco (De audiendis poetis) diz que, na representação artística, o feio imitado permanece feio, mas recebe como que uma reverberação de beleza da mestria do artista. ${ }^{204}$

Portanto, o que provoca a admiração dos leitores modernos — mas também dos ouvintes de outrora - é a arte de Chrétien na composição desse retrato. "Arte" deve ser

\footnotetext{
${ }^{200}$ JAMES-RAOUL, D. Chrétien de Troyes, la griffe d'un style. Paris: Honoré Champion, 2007. p. 356

${ }^{201}$ ECO, U. (Org.). História da feiura. Rio de Janeiro: Record, 2007, p. 113.

${ }^{202}$ Ibid., p. 127.

${ }^{203}$ Ibid., p. 19.

${ }^{204}$ Ibid., p. 20.
} 
entendida aqui em seu sentido antigo de "técnica". Dizendo de outro modo, nosso maravilhamento é provocado pelo domínio de uma técnica na elaboração de um discurso. E este é de tipo descritivo.

Chegamos, portanto, ao ponto em que o retrato do vilão nos permite pensar as relações entre o maravilhoso e o descritivo, reflexão que se iniciará com uma incursão por diferentes discursos proferidos ao longo de séculos sobre a descrição.

\subsection{A sagração da bruxa: da descrição ao descritivo}

\subsubsection{Repulsa secular}

Le verbe lire ne supporte pas l'impératif. Aversion qu'il partage avec quelques autres: le verbe "aimer"... le verbe "rêver"...

On peut toujours essayer, bien sûr. Allez-y: "Aime-moi!" "Rêve!" "Lis!" "Lis! Mais lis donc, bon sang, je t'ordonne de lire!"

- Monte dans ta chambre et lis!

Résultat?

Néant.

Il s'est endormi sur son livre. La fenêtre, tout à coup, lui a paru immensément ouverte sur quelque chose d'enviable. C'est par là qu'il s'est envolé. Pour échapper au livre. Mais c'est un sommeil vigilant: le livre reste ouvert devant lui. Pour peu que nous ouvrions la porte de sa chambre nous le trouverons assis à son bureau, sagement occupé à lire. Même si nous sommes monté à pas de loup, de la surface de son sommeil il nous aura entendu venir.

- Alors, ça te plaît?

Il ne nous répondra pas non, ce serait un crime de lèse-majesté. Le livre est sacré, comment peut-on ne pas aimer lire? Non, il nous dira que les descriptions sont trop longues.

Rassuré, nous rejoindrons notre poste de télévision. Il se peut même que cette réflexion suscite un passionnant débat entre nous et les autres nôtres...

- Il trouve les descriptions trop longues. Il faut le comprendre, nous sommes au siècle de l'audiovisuel, évidemment, les romanciers du XIX avaient tout à décrire...

- Ce n'est pas une raison pour le laisser sauter la moitié des pages!

Ne nous fatiguons pas, il s'est rendormi. ${ }^{205}$

\footnotetext{
205 PENNAC, D. Comme un roman. Paris: Gallimard, 1992. p. 13-14 (grifos meus): “O verbo ler não suporta o imperativo. Aversão que partilha com alguns outros: o verbo "amar"... o verbo "sonhar"... // Bem, é sempre possível tentar, é claro. Vamos lá: "Me ame!" "Sonhe!" "Leia!" "Leia logo, que diabo, eu estou mandando você ler!" // - Vá para o seu quarto e leia! // Resultado? // Nulo. // Ele dormiu em cima do livro. A janela, de repente,
} 
Assim se inicia Comme un roman, de Daniel Pennac. É sintomático que, logo na abertura desse ensaio sobre a leitura, figure a aversão de um jovem leitor à descrição. Esse adolescente não está sozinho em seu (des)gosto, compartilhado por inúmeros leitores que veem as descrições como uma desagradável interrupção daquilo que para eles "realmente interessa", ou seja, a narração das ações.

Narração x descrição. Segundo Gérard Genette, essa oposição, "accentuée par la tradition scolaire, est un des traits majeurs de notre conscience littéraire" ${ }^{206}$. No entanto, esses dois tipos de discurso não foram sempre percebidos em oposição mútua. Genette situa a existência de uma visão antagônica de forma mais intensa a partir do século XIX, embora já reconheça sua presença no século XVII, mais precisamente no trecho da Arte Poética de Boileau em que o autor trata da epopeia. ${ }^{207}$ Adma Muhana encontrou traços de sua existência já no século XVI. ${ }^{208}$ Danièle James-Raoul, por sua vez, defende que a obra de Chrétien se situa num momento de transição entre dois modos de considerar a descrição. Ela se baseia no fato de que Matthieu de Vendôme, no final do século XII, coroando a explosão de descrições na segunda metade daquele século e considerando esse tipo de discurso um elemento essencial da composição poética, concede a ele uma ampla parte de sua Ars versificatoria, ao passo que Geoffroy de Vinsauf, no início do século XIII, trata a descrição como um elemento entre outros, não mais dominante. Além disso, a autora vê, no conjunto da obra de Chrétien, uma progressiva - embora não absoluta - recusa a descrever, o que poderia ser fruto de uma mudança no gosto do público. ${ }^{209}$ Se ela estiver certa, isso significa que poderíamos recuar esse "traço capital de nossa consciência literária" à passagem do século XII para o século XIII.

\footnotetext{
lhe pareceu imensamente aberta sobre uma coisa qualquer tentadora. Foi por ali que ele decolou. Para escapar ao livro. Mas é um sono vigilante: o livro continua aberto diante dele. E no pouco que abrimos a porta de seu quarto, nós o encontramos sentado junto à escrivaninha, seriamente ocupado em ler. Mesmo se nos aproximamos na ponta dos pés, da superfície de seu sono ele nos terá escutado chegar. // - Então, está gostando? // Ele não vai nos responder que não, isto seria um crime de lesa-majestade. O livro é sagrado, como é possível não gostar de ler? Não, ele vai dizer que as descrições são longas demais. // Tranquilizados, voltamos ao nosso aparelho de televisão. E é até possível que esta reflexão suscite um apaixonante debate entre nós e os outros como nós... // Ele acha as descrições longas demais. É preciso entender, estamos no século do audiovisual, evidentemente os romancistas do século XIX tinham que descrever tudo... // - Mas isto não é razão para pular a metade das páginas! // Não vamos nos cansar, ele voltou a dormir." (PENNAC, D. Como um romance. Tradução de Leny Werneck. Rio de Janeiro: Rocco, 1993. p. 13-14.)

${ }^{206}$ GENETTE, G. Frontières du récit. In: _. Figures II. Paris: Seuil, 1969. p. 56: "acentuada pela tradição escolar, é um dos traços capitais de nossa consciência literária".

${ }^{207}$ Ibid., p. 56.

${ }^{208}$ MUHANA, A. A epopeia em prosa seiscentista. São Paulo: UNESP, 1997. p. 302.

209 JAMES-RAOUL, D. Chrétien de Troyes, la griffe d'un style. Paris: Honoré Champion, 2007. p. 98-100.
} 
Seja como for, o fato é que, embora não seja um dado universal e atemporal, a oposição narrativo x descritivo, modernamente, caracteriza a percepção do texto literário, ao menos por parte do leitor comum: Umberto Eco afirma que "as pessoas em geral acreditam que a diferença entre literatura popular e literatura erudita reside no fato de que esta última é repleta de longas descrições, enquanto aquela primeira vai direto ao assunto"210.

Mas voltemos ao jovem leitor do ensaio de Pennac. Para ele, as descrições são enfadonhas, mas, felizmente, identificáveis como unidades textuais claramente delimitadas, o que lhe permite pura e simplesmeste saltá-las. Inúmeros teóricos, entre eles Roland Barthes e Umberto Eco, já dedicaram ao menos algumas linhas de seus escritos ao comentário dessa prática de (não) leitura, o que significa que ela não se resume ao ato isolado de um filho rebelde. Aliás, não apenas esse adolescente não está sozinho em seu desamparo diante do livro, como também tem história. Uma longa história. Daniela Dalla Valle cita o seguinte trecho de um debate entre personagens de La Promenade de Versailles, de Madelaine de Scudéry, do século XVII, sobre as descrições romanescas:

Il me semble que soit en Histoire, soit en Roman, mon esprit cesse d'agir dés que je trouve une description qui l'arreste; et comme rien n'ennuye tant que de ne bouger d'une place, je m'impatiente, je sors du palais ou du jardin, et je cours $[\ldots]$ aprés les Héros et les aventures. ${ }^{211}$

Vê-se que se entediar com as descrições e correr atrás da ação é um comportamento já conhecido no século XVII, o que basta para inocentar o audiovisual, injustamente acusado pelo narrador de Pennac. De fato, desde a Antiguidade, mesmo aqueles que valorizavam o descritivo sempre alertaram contra seus perigos, que basicamente se resumem a cansar o leitor/ouvinte em virtude da interrupção da ação.

O fato de um leitor poder saltar um trecho do texto implica, como foi dito, que ele tenha sido capaz de identificar com relativa facilidade seu início e seu término. Bem, no caso de Yvain ou le Chevalier au Lion, tanto o adolescente do ensaio de Pennac quanto a personagem de Madelaine de Scudéry ficariam um tanto desorientados se tentassem delimitar fronteiras nítidas entre o narrativo e o descritivo. Voltarei a isso em outro momento.

\footnotetext{
${ }^{210}$ ECO, U. Seis passeios pelos bosques da ficção. São Paulo: Companhia das Letras, 2006. p. 73-74.

211 DALLA VALLE, D. Le merveilleux et la vraisemblance dans la description des romans baroques: La promenade de Versailles de Madelaine de Scudéry. XVII siècle, Paris, n. 152, p. 228, juil.-sept. 1986: "Pareceme que, seja em História, seja em Romance, meu espírito cessa de agir assim que encontro uma descrição que o para; e como nada aborrece tanto quanto não sair do lugar, eu me impaciento, saio do palácio ou do jardim, e corro [...] atrás dos Heróis e das aventuras". Agradeço à $\operatorname{Prof}^{a} \operatorname{Dr}^{\mathrm{a}}$ Adma Muhana a indicação desse texto.
} 
Ao saltar uma descrição, o leitor sugere que ela não é essencial, mas acessória e que, portanto, nada se perde em evitá-la. Ele mostra que a considera secundária e, geralmente, desprovida de função. Philippe Hamon $^{212}$ e Jean-Michel Adam ${ }^{213}$ mostram o quanto um público especializado, composto por escritores e preceptistas, partilhou ao longo dos séculos dessa visão pejorativa que hoje possui o leitor comum.

Adam afirma que a descrição foi virulentamente criticada na modernidade, do século XVIII ao XX..$^{214}$ No entanto, precisaríamos relativizar essa afirmação, primeiramente porque, se pensarmos no quanto descrições como as de Balzac e Flaubert serviram para distinguir, ao menos no senso comum, alta literatura de literatura comercial, seremos obrigados a reconhecer que houve, no período mencionado, um tipo de discurso que atribuía grande valor ao descritivo.

Além disso, observando as próprias citações realizadas por Adam (Stendhal, Jacob, Baudelaire, Valéry, Gide, entre outros), perceberemos que, na verdade, muitos dos autores mencionados não são contrários a toda forma de descrição. A descrição que criticam vem, em geral, adjetivada. Assim, Stendhal abomina a descrição material. Baudelaire, por sua vez, acredita que o poeta se degrada ao descrever o que é.

Ora, nem toda descrição se pretende realista. Hamon considera a descrição, mais que o lugar de um "efeito de real", o lugar de um "efeito de poesia". ${ }^{215}$ Quanto não há de descritivo em poemas como "L'albatroz", "La chevelure", "La charogne", entre outras peças de Les fleurs du mal? Portanto, Baudelaire estaria criticando um certo tipo de descrição e não todo e qualquer procedimento descritivo.

Gide, por sua vez, cria um escritor em Les faux-monnayeurs que toma as descrições demasiadamente exatas por algo mais prejudicial à imaginação do que útil a ela. Ora, essa crítica foi inserida na fala de uma personagem, o que não significa necessariamente que ela expresse a opinião pessoal de Gide. Além disso, essa personagem questiona o valor apenas da descrição demasiadamente exata, o que parece, mais uma vez, dirigir-se contra uma pretensão naturalista de certos autores de um certo período.

\footnotetext{
212 HAMON, P. Éléments pour une histoire de l'idée de description. In: Du descriptif. Paris: Hachette, 1993. p. 9-36

${ }^{213}$ ADAM, J.-M. Une rhétorique de la description. In: MEYER, M.; LEMPEREUR, A. (Ed.). Figures et conflits rhétoriques. Bruxelles: Éditions de l'Université de Bruxelles, 1990. p. 168-192. Agradeço à Prof ${ }^{\mathrm{a}} \operatorname{Dr}^{\mathrm{a}}$ Adma Muhana a indicação desse texto. Adam retoma e desenvolve as ideias desse artigo em ADAM, J.-M. La description. Paris: P.U.F., 1993.

${ }^{214}$ ADAM, J.-M. La description. Paris: P.U.F., 1993. p. 5.

${ }^{215}$ HAMON, P. Qu'est-ce qu'une description? Poétique, Paris, n. 12, p. 482, 1972.
} 
De qualquer modo, houve realmente, antes mesmo do século XVIII, teóricos e/ou escritores que alertaram contra o que consideravam os "perigos" da descrição. Adam resume $^{216}$ todas essas críticas elaboradas ao longo de séculos em cinco essenciais.

A primeira delas é a de que a descrição consistiria numa definição imperfeita, que, em vez de apontar a essência das coisas, enumeraria apenas seus atributos, muitas vezes circunstanciais. Os gramáticos de Port Royal opunham "definição", “essencial”, "eterno”, "geral", "exato" e "racional" a "descrição", "acidental", "temporal”, "individual”, "inexato" e “irracional". ${ }^{217}$ De um lado, portanto, temos a definição — "estável e racional” — e, de outro, a descrição - "sujeita aos caprichos e às flutuações da enunciação". ${ }^{218}$ Ora, poesia é pura enunciação. O poético e o ficcional não são lugares da estabilidade, do racionalismo e da exatidão. Assim, se a descrição se opõe a tudo o que é exato e definitivo, não poderíamos dizer que é justamente nela que reside o poético? Não poderíamos, contrariando Max Jacob - que definia o estilo descritivo como um estilo científico, "o contrário da poesia"219 —, afirmar que o descritivo consiste na própria essência da poesia?

Uma segunda crítica à descrição recai sobre sua incapacidade de reproduzir o real. Adam cita, como exemplo, a anedota contada por Diderot no artigo "Enciclopédia" do Dictionnaire Encyclopédique, na qual cem pinturas feitas por cem pintores diferentes a partir da descrição de uma mulher não se pareciam uma com a outra nem com a mulher, embora todas se parecessem estreitamente com a descrição. ${ }^{220}$

Ora, mais uma vez, não poderíamos afirmar ser justamente aí, nessa diferença, que reside o poético? Os cem retratos não são mulheres, mas pinturas, ou, dito de outro modo, não são $o$ real, mas imitações. Assim, se é verdade que as descrições não constituem cópias fiéis da realidade, é verdade também que não devemos considerar essa "incapacidade" em retratar o real como uma falta, mas como o elemento que torna a descrição a essência do ficcional, em seu sentido etimológico, relacionado à ideia de fingimento.

O terceiro tipo de crítica recai sobre o aspecto arbitrário e desordenado da descrição. Sendo um solo propício para a explosão de detalhes, muitas vezes considerados inúteis, a descrição não tem limites precisos, ou seja, podemos descrever um objeto ao infinito. Além disso, não há uma ordem necessária entre os elementos da descrição. Assim, podemos descrever uma paisagem começando e terminando por qualquer um de seus componentes.

\footnotetext{
${ }^{216}$ ADAM, J.-M. Un rejet presque unanime. In: La description. Paris: P.U.F., 1993. p. 5-25.

${ }^{217}$ Ibid., p. 7.

${ }^{218}$ ADAM, J.-M. Une rhétorique de la description. In: MEYER, M., LEMPEREUR, A. (Ed.). Figures et conflits rhétoriques. Bruxelles: Éditions de l'Université de Bruxelles, 1990. p. 165.

${ }^{219}$ ADAM, J.-M. La description. Paris: P.U.F., 1993. p. 5.

${ }^{220}$ Ibid., p. 10.
} 
Desde o tempo em que dominava a Retórica, os preceituários procuraram domar esse aspecto caótico da descrição. Assim, por exemplo, sabemos que os retratos e as descrições de animais deveriam começar de cima para baixo, ou seja, da cabeça aos pés. Adam mostra como, mesmo depois do declínio da Retórica, autores como Flaubert e Zola, embora não mais seguindo os preceitos para a descrição, mantiveram essa ordem. ${ }^{221}$

Portanto, os escritores encontraram maneiras de solucionar o problema da aparente desordem da descrição. "Aparente", pois, como veremos ao tratarmos do funcionamento do texto descritivo, ele segue um padrão que pode ser bastante rígido.

O quarto tipo de crítica identifica nas descrições uma propensão ao clichê e ao lugarcomum. $^{222}$ De fato, topografias, retratos e outros tipos de textos descritivos chegaram a ser extremamente codificados. No entanto, devemos abordar com cuidado essa questão, levando em conta uma série de fatores. Por um lado, a originalidade, tal qual a entendemos hoje, nunca foi critério para se pensar a produção de textos antes do Romantismo. Por outro, a utilização de um padrão relativamente rigoroso de composição de textos antigos não excluía a possibilidade de variações. Ao contrário, elas eram esperadas. O prazer proporcionado por um texto originava-se simultaneamente do reconhecimento de um modelo e da surpresa diante da variação. O próprio Chrétien de Troyes, como teremos a ocasião de verificar, é um exemplo disso.

Devemos pensar também que aquilo que talvez nos pareça um clichê por sua repetição exaustiva em textos diferentes pode desempenhar funções diversas em cada uma de suas aparições. Ao repetir um padrão discursivo utilizado por outrem, provoco um deslocamento: retiro o dito de seu contexto e insiro-o num outro, ressignificando-o. Assim, a percepção da repetição é atenuada e o deslocamento efetuado torna-se a figura central.

Finalmente, a quinta crítica à descrição se refere à sua tendência à despersonalização. Pode-se descrever tanto seres humanos quanto seres inanimados. Esse é um ponto de conflito com a narrativa, que tem como um de seus componentes básicos a presença central e permanente de pelo menos uma personagem, sendo, portanto, mais centrada no homem. ${ }^{223}$ Por isso, a descrição corre o risco de se apresentar como uma quebra na narrativa.

Assim, muitos teóricos insistiram na necessidade de a descrição não ser fria e de não deixar de lado o elemento humano, ainda que este apareça apenas como uma sugestão do estado de espírito daquele que descreve.

\footnotetext{
${ }^{221}$ ADAM, J.-M. La description. Paris: P.U.F., 1993. p. 18.

${ }^{222}$ Ibid., p. 22.

${ }^{223}$ Ibid., p. 73.
} 
Uma das maneiras apontadas pelos mestres da Retórica e da estilística para evitar esse problema é ater-se à descrição de ações, seja descrevendo uma cena ou quadro — em que há a presença humana e a impressão de movimento - , seja descrevendo um procedimento, como a fabricação de um objeto. ${ }^{224}$ Embora esses dois tipos se destaquem, há outros como a descrição de batalhas e de passeios ou viagens.

Essa desconfiança secular em relação à descrição chamou a atenção de teóricos e críticos literários da segunda metade do século XX sobre o fenômeno descritivo. Seus estudos levaram-nos a reabilitar a descrição, por encontrarem nela, contrariando discursos anteriores, funções diversificadas e um funcionamento próprio, como veremos a seguir.

\subsubsection{De opositora a auxiliar: funções da descrição}

Vimos que a descrição foi, muitas vezes, considerada um acúmulo de detalhes inúteis, que, ao interromperem a ação, levam o leitor entediado a saltar trechos inteiros. Assim, uma das razões pelas quais muitos leitores se recusam a ler descrições é o fato de acreditarem que elas não servem para nada e que, ao contrário, apenas atrapalham o prazer sentido em acompanhar uma história. Ora, vimos que o retrato do vilão não tem nada de gratuito e, mais que isso, ao produzir efeitos sobre o público, é responsável por grande parte do prazer da leitura ou da audição. Mas muitos leitores ainda não conseguem identificar a função de passagens descritivas para a economia da obra. Foi justamente esse o ponto de que mais se ocuparam os especialistas da segunda metade do século $\mathrm{XX}$ e que serviu a um primeiro movimento de reabilitação da descrição, no qual, no entanto, ela ainda ocupa uma posição secundária.

Em "Frontières du récit", Gérard Genette afirma a impossibilidade de narrar sem descrever, embora o contrário lhe pareça absolutamente possível. Isso deveria conferir à descrição uma autonomia suficiente para fazê-la ocupar o primeiro plano numa narrativa. No entanto, dá-se justamente o contrário: a descrição apresenta-se sempre subordinada à narração, como simples auxiliar. Assim, o estudo das relações entre narrativo e descritivo

${ }^{224}$ ADAM, J.-M. La description. Paris: P.U.F., 1993. p. 76. 
consiste sempre em interrogar-se sobre a função de uma unidade descritiva para a economia geral da narrativa. ${ }^{225}$

Pensando no que chama "tradição literária clássica", de Homero ao fim do século XIX, Genette vê duas funções distintas. A primeira é decorativa. O autor afirma que a Retórica antiga incluía a descrição entre os ornamentos do discurso, "comme une pause et une récréation dans le récit". ${ }^{226}$ A segunda função, simultaneamente explicativa e simbólica, tendo-se imposto com Balzac, seria a mais difundida hoje. A descrição física de uma personagem, bem como a de seu meio, revela e justifica sua psicologia. ${ }^{227}$ Diante disso, Genette afirma: “La description devient ici, ce qu'elle n'était pas à l'époque classique, un élément majeur de l'exposition". 228

A substituição da função ornamental por uma função significativa, segundo Genette, fez a descrição ganhar em dramaticidade, mas perder em autonomia, já que sua subordinação à narrativa tornou-se mais acentuada. ${ }^{229}$

Adam e Petitjean também utilizam o termo "ornamental" ${ }^{230}$ para caracterizar um tipo de descrição que, segundo eles, reinou absoluto no contexto das Belas Letras, anterior à existência da Literatura como instituição, ou seja, da Antiguidade até meados do século XVIII. A partir de então, passa a coexistir com o tipo expressivo. Em vez de "substituição", como escreve Genette, os autores preferem pensar em termos de coexistência. Eles destacam que o surgimento de uma nova função descritiva não vem aniquilar a anterior, mas somar-se a ela ${ }^{231}$, ainda que, em virtude de gostos de época, tenda a suplantá-la.

A associação de Genette entre textos antigos e função ornamental, de um lado, e textos modernos e função significativa, de outro, parece-me um tanto redutora. A afirmação de que, nos textos antigos, a função da descrição era sobretudo ornamental foi reavaliada por Perrine Galand-Hallyn. ${ }^{232}$ A autora reconhece que, tanto na Antiguidade quanto nos tempos modernos, muitos daqueles que se debruçaram sobre o assunto tenderam a considerar os trechos descritivos desse modo. No entanto, ela mostra que, já em Cícero e em Quintiliano, havia uma percepção do poder argumentativo da descrição. A extensão de certas descrições

\footnotetext{
${ }^{225}$ GENETTE, G. Frontières du récit. In: Figures II. Paris: Seuil, 1969. p. 57-58.

${ }^{226}$ Ibid., p. 58: "como uma pausa e uma recreação na narrativa".

${ }^{227}$ Ibid., p. 58-59.

${ }^{228}$ Ibid., p. 59: “A descrição torna-se aqui o que ela não era na época clássica, um elemento primordial da exposição".

${ }_{229}$ Ibid., p. 59.

${ }^{230}$ ADAM, J-M.; PETITJEAN, A. Le texte descriptif. Paris: Nathan, 1989. p. 8.

231 Ibid., p. 69.

${ }^{232}$ GALAND-HALLYN, P. Art descriptif et argumentation dans la poésie latine. In: MEYER, M.; LEMPEREUR,

A. (Ed.). Figures et conflits rhétoriques. Bruxelles: Éditions de l’Université de Bruxelles, 1990. p. 39-57.
} 
fazia com que se criticasse esse tipo de discurso pelo perigo da digressão. Mas Cícero e Quintiliano reabilitam a digressão, considerando-a útil, desde que pertinente para a causa em questão. Basicamente, as digressões a que se referem assumem a função de exemplos, os quais, muitas vezes, agindo mais sobre a emoção que sobre o raciocínio, poderiam ser úteis para a persuasão dos ouvintes.

Deixemos de lado os tribunais e passemos à poesia. Também nela, segundo GalandHallyn, a utilidade da descrição se fazia sentir. Ao lerem seus textos, os antigos não se restringiam ao sentido literal, mas consideravam que eles traziam sempre algum tipo de ensinamento, além de consistir em modelos de escritura. Assim, o ornato não parece gratuito, mas sim algo contendo um sentido, ainda que não perceptível de imediato. ${ }^{233}$

Esse modo de ler dos antigos, bem como as descobertas contemporâneas de que as aparentes digressões descritivas são importantes para o bom funcionamento da narrativa e de que nelas concentram-se importantes signos metalinguísticos, justifica a tese da autora de que muitas dessas descrições constituem metáforas do próprio texto. Assim, sem negar a existência de outras funções, Galand-Hallyn interessa-se sobretudo pela função autorrepresentativa da descrição.

Vimos, por exemplo, Jean-Michel Adam apresentar a descrição de objetos em pleno processo de fabricação como uma estratégia proposta por retores para se evitar o estatismo das descrições. Na perspectiva de Galand-Hallyn, trata-se de mais do que isso: o trabalho do artesão consiste numa mise en abyme do trabalho do próprio escritor. ${ }^{234}$

O que permite ao leitor identificar esse tipo de descrição como metáfora? Primeiramente, o caráter não mimético e sim imaginário da descrição, ou seja, o fato de que não se imita um objeto real, mas elabora-se linguisticamente um objeto fruto da imaginação. Além disso, certa dose de abstração e esoterismo: em vez de suscitar uma visão imediata do objeto descrito, o poeta "oblige le lecteur à compléter par son érudition et sa mémoire les détails manquants". ${ }^{235}$ A não referencialidade da descrição chama a atenção do leitor para o seu tema como variante intertextual e não como reflexo de um objeto real. Assim, quando Virgílio, no canto sexto da Eneida, descreve o portal do templo de Apolo, não é o portal que descreve, mas a narração do mito de Dédalo, ou seja, descreve-se não um objeto, mas um procedimento discursivo, que se apresenta como modelo. Portanto, a construção do poeta se substitui à confecção do artesão.

\footnotetext{
${ }^{233}$ GALAND-HALLYN, P. Art descriptif et argumentation dans la poésie latine. In: MEYER, M.; LEMPEREUR, A. (Ed.). Figures et conflits rhétoriques. Bruxelles: Éditions de l’Université de Bruxelles, 1990. p. 41.

${ }^{234}$ Ibid., p. 48.

${ }^{235}$ Ibid., p. 49: "obriga o leitor a completar com sua erudição e sua memória os detalhes faltantes".
} 
Precisamos ter o cuidado de não cristalizar algo que é variável. Assim, Galand-Hallyn interessa-se pela função autorrepresentativa da descrição, o que não significa, como já foi dito, que se trate de uma função única e nem que esteja presente em todo e qualquer trecho descritivo.

Umberto Eco chama a atenção para essa variedade de funções que os trechos descritivos podem assumir em seus diferentes contextos. Ele lembra, por exemplo, que, muitas vezes, a abundância de detalhes não consiste tanto num procedimento de representação quanto numa estratégia para desacelerar a leitura e obrigar o leitor a adotar um ritmo que o autor considera necessário para a fruição do texto ${ }^{236}$. Essa demora narrativa produz o que Eco chama "tempo de trepidação", que visa a retardar um final dramático. ${ }^{237} \mathrm{O}$ autor se refere a Aristóteles, para quem um conjunto de peripécias deveria preceder a catástrofe e a catarse. Se o leitor tivesse que esperar menos para o desfecho e se a trepidação fosse menos intensa, a catarse não se realizaria completamente. ${ }^{238}$

Portanto, as descrições constituem uma das maneiras de retardar os acontecimentos numa narrativa. Mas essa desaceleração pode ser empreendida de modos diferentes, obtendose efeitos também diferentes. Assim, é possível deter-se em detalhes supérfluos, que não contribuem em nada para o desenrolar dos acontecimentos, pelo simples prazer da demora, que tem como efeito tornar a história mais empolgante. É o que Eco chama "função erótica da delectatio morosa"239. Mas é também possível demorar-se em algo não supérfluo e sim explicativo, algo que permite ao leitor compreender melhor uma dada situação e emocionar-se mais com ela.

Outra função da descrição refere-se ao que Eco denomina "tempo de alusão" 240 . Muitas vezes, a demora em descrições aparentemente supérfluas indica que o texto está nos convidando a ler tal passagem como simbólica ou alegórica. É assim, por exemplo, que Santo Agostinho via o fato de o texto bíblico se deter sobre a descrição de vestimentas, jóias e outros objetos mundanos. ${ }^{241}$

Uma última função lembrada por Eco é a de criar a ilusão de espaço. Ele se refere à hipotipose, figura de retórica que visa, por meio do código verbal, a colocar algo sob os olhos do ouvinte/leitor, como se de fato o estivesse vendo. E um dos modos de fazê-lo "consiste em

\footnotetext{
${ }^{236}$ ECO, U. Seis passeios pelos bosques da ficção. São Paulo: Companhia das Letras, 2006. p. 65.

${ }^{237}$ Ibid., p. 70.

238 Ibid., p. 70-71.

239 Ibid., p. 74.

240 Ibid., p. 74.

241 Ibid., p. 74.
} 
expandir o tempo do discurso e o tempo de leitura em relação ao tempo da história". ${ }^{242}$ Este é o tempo dos acontecimentos, do conteúdo da narrativa. Já o tempo do discurso refere-se ao tempo de escrever e de ler as frases que narram/descrevem os acontecimentos. Esse tempo não depende tanto da extensão do texto quanto do ritmo de leitura que o texto impõe ao leitor. $^{243}$

Como não se trata aqui de um estudo teórico sobre a descrição, mas da leitura de um retrato presente num romance do século XII, não procurei esgotar todas as funções que cada teórico atribuiu aos trechos descritivos. Assim, por exemplo, não comentarei aqui as categorias apontadas por Adam e Petitjean ${ }^{244}$, a saber, a descrição expressiva, a representativa e a produtiva, que os autores associam respectivamente às produções romântica, realista/naturalista e do nouveau roman, escapando, portanto, do nosso âmbito de estudo. ${ }^{245}$

O importante é perceber a diversidade de funções que um segmento descritivo pode assumir numa narrativa. Diante de tamanha variedade, torna-se impossível desprezar como supérfluas, cansativas ou excessivas essas "unidades de composição textual"246, as quais não podem ser suprimidas sem que se altere o efeito produzido pelo texto sobre o leitor.

Tendo constatado a importância dos trechos descritivos, passemos agora a examinar seu funcionamento, já atentando para o modo como ele se dá em Yvain ou le Chevalier au Lion.

\subsubsection{No princípio era o Caos...}

Vimos que a descrição foi atacada também pelo fato de, aparentemente, não possuir nenhum princípio organizativo, não importando a ordem de seus elementos, nem tampouco limites precisos, o que nos permitiria descrever um objeto indefinidamente.

Desconfiando desse suposto desregramento da descrição e do procedimento secular de defini-la negativamente, como uma falta em relação a algo exterior a ela mesma — definição

\footnotetext{
${ }^{242}$ ECO, U. Seis passeios pelos bosques da ficção. São Paulo: Companhia das Letras, 2006. p. 77.

243 Ibid., p. 60 e 62.

244 ADAM, J-M.; PETITJEAN, A. Le texte descriptif. Paris: Nathan, 1989.

245 Do mesmo modo, não mencionarei aqui as funções da descrição enumeradas por Philippe Hamon. Elas exigiriam que eu expusesse primeiramente aspectos mais complexos de sua teoria, o que foge ao escopo deste item e que só farei parcialmente mais adiante. Aos interessados, remeto à nota 46 da página 484 de HAMON, P. Qu'est-ce qu'une description? Poétique, Paris, n. 12, p. 465-485, 1972.

${ }^{246}$ ADAM, J.-M. La description. Paris: P.U.F., 1993. p. 93.
} 
imperfeita, ausência de ação, etc. - , alguns teóricos contemporâneos começaram a se perguntar se a descrição não possuiria uma natureza própria, com suas riquezas e dificuldades específicas.

Um deles foi Jean-Michel Adam. Ele percebeu que, durante séculos, os estudiosos de retórica e de estilística procuraram classificar os diferentes tipos de descrição. Assim, teríamos a topografia (descrição de um lugar), a cronografia (descrição de um tempo, uma época), a prosopografia (descrição das características físicas de um ser animado), a etopeia (descrição das características morais de um ser animado), o paralelo (descrições de dois objetos visando a uma comparação), o quadro (descrições animadas de ações, acontecimentos, de fenômenos). ${ }^{247}$ Enfim, uma série de tipos foram identificados, mas cada mestre de retórica ou de estilística adotava uma classificação diferente, que lhe parecia mais adequada, ora destrinchando uma mesma categoria de um sistema precedente em subcategorias, ora, ao contrário, reunindo dois tipos em um.

Vimos que uma das críticas feitas à descrição recaía sobre sua tendência à despersonalização e que um dos meios de combatê-la consistia em não deixar de lado o elemento humano, descrevendo, por exemplo, em vez de um objeto pronto e estático, um objeto em pleno processo de fabricação. Segundo Adam, essa valorização do humano explica por que o retrato foi a única categoria que sobreviveu à incorporação de todas as outras pelo termo genérico "descrição". ${ }^{248}$ Mas a flutuação das classificações retóricas levaram-no a pensar que o critério referencial sobre o qual elas se baseavam e sobre o qual continua se baseando a oposição retrato (humano) x descrição (inumano), não permite perceber a especificidade da descrição como unidade de composição textual. É essa percepção que o autor, adotando uma perspectiva linguística e textual, busca no último capítulo de seu $L a$ description $^{249}$, que passo a apresentar.

Uma das críticas à descrição, vimos, é a de que se trataria de uma definição imperfeita, que se contentaria em enumerar os atributos de seu objeto. Contrariando essa posição, Adam defende que a enumeração é apenas o estágio primário da descrição e que esta difere daquela por um nível complexo de organização que a primeira não possui nem minimamente. Vejamos então as quatro operações constituintes de toda sequência descritiva: ancoragem, aspectualização, mise en relation ${ }^{250}$ e subtematização.

\footnotetext{
${ }^{247}$ ADAM, J.-M. Une rhétorique de la description. In: MEYER, M., LEMPEREUR, A. (Ed.). Figures et conflits rhétoriques. Bruxelles: Éditions de l'Université de Bruxelles, 1990. p. 168-169.

248 ADAM, J.-M. La description. Paris: P.U.F., 1993. p. 93.

${ }^{249}$ ADAM, J.-M. Un point de vue linguistique et textuel. In:

${ }^{250}$ Algo como "estabelecimento de relações". La description. Paris: P.U.F., 1993. p. 93-122.
} 
A primeira, a operação de ancoragem, é dividida por Adam em três tipos. Destes, o primeiro é a ancoragem propriamente dita, em que se nomeia de antemão o objeto descrito. Graças a esse procedimento, o leitor pode convocar seu saber enciclopédico sobre aquilo que vai ler. É o que ocorre com nosso recorte, que já começa nomeando seu tema-título (uns vileins), antes de descrevê-lo. Isso permite, como observamos, uma série de antecipações por parte do público, que Chrétien frustrará em seguida. O segundo é a afetação, quando se descreve primeiramente o objeto para, apenas no fim, nomeá-lo. O leitor entra num jogo de adivinhação e hipóteses, que só se confirmarão ou serão refutadas no final. O terceiro e último, a reformulação, ocorre quando se retoma o tema-título da descrição, modificando-o.

Por meio da segunda operação, a aspectualização, isolam-se aspectos (propriedades e/ou partes) do tema-título. No caso que nos interessa, temos um tema-título "vilão", ao qual se atribuem propriedades (leiz, hideus a desmesure, tres leide criature qu'an ne porroit dire de boche) e que é dividido em partes (main, teste, piz, eschine, robe, col). A atribuição de propriedades conserva a unidade do todo, enquanto a nomeação de partes promove uma fragmentação. Ambas implicam um olhar subjetivo ${ }^{251}$ por parte daquele que descreve.

Não devemos entender aqui "subjetividade" no sentido romântico de expressão de uma interioridade única e inspirada, a do autor. Não podemos nos esquecer de que o poema de Chrétien, composto no século XII, num contexto em que ainda reina a Retórica, pauta-se em grande parte por regras e preceitos que têm como meta garantir a realização do(s) objetivo(s) de um discurso - docere, movere e/ou delectare - e não promover a expressão de uma individualidade.

Assim, compreendamos "subjetividade", aqui, no sentido de que há escolhas envolvidas numa descrição: escolha das propriedades a serem atribuídas ao tema-título e escolha de suas partes a serem mencionadas. Embora existam adjetivos aparentemente neutros, há outros que manifestam de modo mais explícito uma escala de valores. Assim, dizer que um terno é preto ou que um homem é casado não compromete tanto o autor da descrição quanto dizer que alguém é bonito ou feio, bom ou mau (adjetivos axiológicos, que expressam juízos de valor). A escolha dos elementos que compõem a descrição pode variar de acordo com o ponto de vista - quem vê o objeto descrito? - e com o efeito que se pretende produzir. É aí que reside o caráter argumentativo da descrição.

\footnotetext{
${ }^{251} \mathrm{Na}$ verdade, Adam não utiliza o termo "subjetivo", mas menciona uma "prise en charge énonciative", o que supõe a existência de um sujeito que se encarrega da descrição, que assume sua responsabilidade por ela. (ADAM, J.-M. La description. Paris: P.U.F., 1993. p. 110)
} 
Mesmo no contexto da Retórica, escolhas são feitas. Contrariamente ao que às vezes se pensa, a existência de preceitos e modelos não significa que as produções anteriores ao Romantismo consistissem em cópias servis e a própria arte do retrato nos fornece exemplos disso.

Annie Combes mostrou que o retrato medieval se caracteriza, em geral, pela imobilidade da personagem, a qual, mesmo quando surpreendida em meio a suas atividades, é retirada de seu contexto e descrita como uma escultura de pedra. ${ }^{252}$ Essa tendência, no entanto, não impede um poeta do porte de Chrétien de Troyes de introduzir variações muito interessantes. No início das aventuras de Le Chevalier au Lion, Laudine é flagrada numa ação que não se apaga em seu retrato: a senhora de Landuc se dilacera, enquanto lamenta a morte do marido, Esclados o Ruivo. Cada parte de seu corpo é mencionada e caracterizada a partir de uma ação: os cabelos, mais reluzentes que o ouro, que ela arranca; os olhos, de beleza singular, que se enchem de lágrimas; o rosto bem formado, fresco e corado, que ela fere; o colo, mais claro e reluzente que qualquer espelho ou cristal, que ela aperta com fúria; as mãos, belas, que ela retorce; os seios, que ela estapeia e arranha. Nada mais distante, portanto, da tendência à petrificação apontada por Annie Combes. Aumenta o interesse desse retrato o fato de ser inserido num monólogo interior de Yvain. É o próprio herói, que, de uma janela, vê e descreve as investidas de Laudine contra sua beleza.

Segundo Catherine Blons-Pierre, apesar de seguirem princípios retóricos de elaboração de retratos, as descrições das diferentes personagens dos romances de Chrétien possuem cada uma sua especificidade. ${ }^{253}$ De fato, Énide é descrita logo em sua primeira aparição diante de Érec e, se o narrador insiste, num segundo momento, sobre sua beleza, o primeiro aspecto mencionado é o mau estado de suas roupas. Isso já configura uma variação, uma vez que a tendência da poesia do período, segundo a autora, é destacar a relação entre riqueza vestimentária e beleza das personagens. ${ }^{254}$ Essa associação direta não vale, no entanto, para os romances de Chrétien, como mostra não apenas o caso de Énide, mas também o de Soredamor, cujas roupas são evocadas não por sua riqueza ou beleza, mas como lamentável obstáculo à visão do descritor! ${ }^{255}$ Este é uma personagem, Alexandre. Assim como ocorre com a descrição de Laudine, o retrato de Soredamor foi inserido num monólogo interior do

${ }^{252}$ COMBES, A. Comme un rêve de pierre: l'imaginaire de la sculpture dans le portrait médiéval. In: CONNOCHIE-BOURGNE, C. (Org.). Façonner son personnage au Moyen Âge. Aix-en-Provence: P.U.P., 2007. p. 123-134.

${ }^{253}$ BLONS-PIERRE, C. L'esthétique de la description des personnages chez Chrétien de Troyes. Bien dire et bien aprandre, Lille, n. 11, p. 55-68, out. 1993. La description au Moyen Âge.

${ }^{254}$ Ibid., p. 62.

255 Ibid., p. 58. 
herói. Mas, desta vez, o cavaleiro não vê o objeto de sua descrição. O retrato é composto mentalmente, à medida que o herói apaixonado relembra a imagem de sua amada. Assim, diferenças de pontos de vista introduzem variações nos retratos das heroínas.

Já quanto aos protagonistas masculinos, Chrétien parece preferir a etopeia à prosopografia, ou seja, privilegiar a descrição das qualidades morais em detrimento das características físicas. ${ }^{256}$

Portanto - mesmo num contexto em que reina a Retórica - entre autores distintos e até entre as várias personagens de um mesmo autor, há diferenças significativas oriundas da introdução de pontos de vista diversos e da realização de escolhas visando a um efeito.

A terceira operação na base de uma sequência descritiva é a mise en relation. Uma de suas formas consiste em situar (mise en situation) o objeto temporal e/ou espacialmente. A mise en situation temporal corresponde à cronografia clássica; a espacial, à topografia. À outra forma, Adam chama assimilação. Ela consiste em estabelecer relações recorrendo à analogia e pode ser tanto comparativa quanto metafórica. No caso do vilão, temos a assimilação por comparação a um mouro (qui resanbloit Mor).

A quarta operação, a subtematização, constitui a fonte da expansão descritiva. No caso de nosso recorte, temos o tema-título "vilão" ao qual se atribuem qualidades. Mas esse tematítulo é fragmentado em partes que podem ser tomadas, cada uma, como novos temas. Assim, descrevem-se, por exemplo, a cabeça e as roupas do vilão. Mas o subtema "cabeça" é também submetido às mesmas operações. Pela aspectualização, ele é qualificado (grosse) e subdividido em novas partes (chevox, front, oroilles, sorcix, vis, ialz, nes, boche, danz, barbe, grenons, manton). Pela mise en relation por assimilação comparativa, ele é aproximado à cabeça de um cavalo (plus que roncins). Mas cada uma das partes da cabeça pode ser convertida em novo subtema e, passando pelas mesmas operações, receber novos atributos (oroilles mossues et granz) e ser novamente mise en relation (autiex com a uns olifanz).

Essa quarta operação confere, de fato, às descrições uma infinitude potencial. Mas, contrariamente ao que afirmavam os detratores da descrição, sua extensão não é (in)determinada por um capricho do autor, e sim por seu caráter argumentativo. Assim, para Adam, os limites de uma descrição são impostos por sua função num dado discurso. ${ }^{257}$

\footnotetext{
${ }^{256}$ BLONS-PIERRE, C. L'esthétique de la description des personnages chez Chrétien de Troyes. Bien dire et bien aprandre, Lille, n. 11, p. 61, out. 1993. La description au Moyen Âge.

${ }^{257}$ ADAM, J.-M. Une rhétorique de la description. In: MEYER, M., LEMPEREUR, A. (Ed.). Figures et conflits rhétoriques. Bruxelles: Éditions de l'Université de Bruxelles, 1990. p. 189. ; ADAM, J.-M. La description. Paris: P.U.F., 1993. p. 114.
} 
Tendo mostrado que um número limitado de operações participa de qualquer tipo de procedimento descritivo, Adam procura em seguida examinar os elementos que estão na base da singularização de cada descrição. Assim, ele passa a se ocupar de dois aspectos complementares: a configuração semântica da descrição e o jogo da enunciação.

O primeiro deles relaciona-se diretamente à escolha das propriedades atribuídas ao tema-título. Adam afirma que a semantização das representações descritivas resultam da escolha de adjetivos mais ou menos valorativos e de comparações e metáforas que orientem a interpretação por parte do leitor. Mas as partes em que se divide um tema-título também não são neutras: assim, utilizar "mansões" ou "barracos" na descrição de um bairro já orienta a leitura, mais do que se se empregasse simplesmente "casa" ou "moradia". O mesmo ocorre se, num retrato, aquele que descreve mencionar o "beiço" e não a "boca" da personagem. Assim, a escolha lexical leva o leitor a construir redes de sentidos (isotopias) e, dessa forma, a interpretar a representação descritiva.

Quanto ao jogo da enunciação, Adam lembra que, do mesmo modo como numa narrativa o sujeito que fala é variável - já que o narrador tem a opção de ceder a palavra às personagens -, o sujeito que vê também o é. Trata-se da focalização, que pode ocorrer em diferentes níveis, como vimos com os retratos das heroínas de Chrétien de Troyes e com a fonte da tormenta, descrita, primeiramente, de memória, pelo vilão - mas cuja fala é reportada diretamente por Calogrenant - em seguida, também de memória, pelo próprio cavaleiro - que percebe elementos que escaparam à percepção do homem selvagem - e, finalmente, pelo narrador, de forma resumida, quando Yvain finalmente chega a Landuc.

Portanto, a semantização da descrição e o jogo enunciativo conferem — pela variedade de formas e níveis que podem assumir — a cada descrição seu caráter único.

Antes de Jean-Michel Adam, outros nomes se dedicaram ao estudo da descrição. Dentre eles, o de maior destaque é, sem dúvida, Philippe Hamon. Em 1972, ele publica um $\operatorname{artigo}^{258}$ a partir de uma pergunta primária (“o que é uma descrição?”), mas cuja resposta dá origem a um texto interessantíssimo, do qual retomarei apenas alguns elementos que nos concernem mais diretamente, já os confrontando com minha leitura de Yvain ou le Chevalier au Lion.

O primeiro deles diz respeito ao modo como as descrições se inserem num conjunto textual mais amplo. Analisando os romances de Zola, Hamon percebe a existência de

\footnotetext{
${ }^{258}$ HAMON, P. Qu'est-ce qu'une description? Poétique, Paris, n. 12, p. 465-485, 1972.
} 
estruturas que se repetem, formando um padrão. Assim, num primeiro momento, temos a conjunção de uma personagem $A$ (ou de duas personagens $A$ e $B$ ) e de um objeto ou cenário $C$. A partir disso, três situações podem ocorrer: 1 . um trabalho de $A$ sobre $C$ diante de $B ; 2$. uma fala de $A$ a $B$ sobre $C$; ou 3. um olhar de $A$ diretamente sobre $C$. O resultado é uma transferência de informação a $B$ ou, no terceiro caso, a $A .^{259}$

Embora Hamon parta de romances naturalistas, ao confrontar-se essa formulação geral com Le Chevalier au Lion, verifica-se nessa obra a existência da segunda e da terceira situações elencadas por ele, com destaque para a segunda. De fato, a palavra desempenha um papel de relevo nesse romance de Chrétien. Há uma grande abundância de narrativas embutidas. O episódio do vilão fornece um ótimo exemplo desse procedimento, pois configura uma embutidura em três níveis: dentro da narrativa-moldura - a das aventuras de Yvain - há uma personagem - Calogrenant - que narra/descreve seu encontro com um vilão horrendo, que, por sua vez, toma a palavra para descrever o que se passa quando se rega uma pedra com a água de uma fonte mágica. Assim, a transformação da fonte de locus amoenus em locus horridus (terceiro nível) nos é apresentada primeiramente na fala do vilão, que nos fora descrito no relato feito por Calogrenant de uma aventura ocorrida sete anos antes (segundo nível), relato esse introduzido na história-moldura pelo narrador em terceira pessoa (primeiro nível).

Há outros exemplos. Ao esquecer o prazo estipulado por sua esposa para retornar a Landuc, Yvain é notificado da inevitável dissolução de seu casamento por uma mensageira enviada por Laudine à corte de Arthur. Como, logo em seguida, o herói atravessa um período de loucura, vivendo como um animal selvagem em meio à floresta, ele não sabe nada sobre o que se passa em Landuc após a ruptura por parte de sua esposa. E o leitor/ouvinte partilha da ignorância do protagonista. Herói e público só saberão o que se passou quando, já curado, Yvain casualmente chega à capela na qual a donzela Lunete, que tanto o ajudara junto a Laudine, está aprisionada. E é ela quem lhe descreve as causas de sua prisão.

À noite, Yvain é hospedado num castelo próximo. Seu anfitrião passa por grande sofrimento, que ele mesmo - e não o narrador em terceira pessoa - descreve ao cavaleiro. E desta forma o gigante Harpin da Montanha entra na história: por meio de mais uma narrativa/descrição embutida.

Merece destaque o fato de tanto o castelão quanto Lunete, na passagem precedente, lamentarem não ter podido contar com a ajuda de Monsenhor Gauvain, ausente devido ao

\footnotetext{
${ }^{259}$ HAMON, P. Qu'est-ce qu'une description? Poétique, Paris, n. 12, p. 472, 1972.
} 
rapto da rainha Guenièvre, que o cavaleiro pretende resgatar. Esse evento é mencionado em rápidas palavras, mas é digno de nota por tratar-se da intriga de outro romance de Chrétien: Lancelot ou le Chevalier de la Charrette, que muitos críticos julgam ter sido composto concomitantemente a Yvain. Ora, isso significa que não apenas Le Chevalier au Lion é repleto de narrativas embutidas, como ainda remete a uma outra narrativa que está fora do romance, mas acontecendo ao mesmo tempo, num magnífico exemplo de intertextualidade!

No episódio do Castelo da Pior Aventura, quando Yvain se depara com o triste espetáculo das nobres escravizadas trabalhando como tecelãs, é uma dessas mulheres quem lhe narra os acontecimentos que as levaram a tamanha desgraça, cuja origem remonta a uma viagem do rei da Ilha das Virgens. Mas essa nova narradora não se limita a relatar fatos, descrevendo também, em detalhes, sua situação atual de miséria. Assim, os dois filhos de um diabo também adentram o romance por meio de uma narrativa embutida.

Portanto, o narrar - bem como o descrever - é muito importante em Yvain, o que fica nítido não apenas pela própria existência de tantas embutiduras, mas também por um discurso dos narradores - o principal e os provisórios - que irrompe em certos momentos, mais ou menos discretamente, mas sempre chamando a atenção para algum aspecto da atividade narrativa. Um desses aspectos é o prazer provocado pela audição de uma história:

Voit apoié desor son cote Un riche home qui se gisoit Sor un drap de soie, et lisoit Une pucele devant lui En un romans, ne sai de cui. Et por le romans escoter $S$ ' $i$ estoit venue acoter Une dame, et s'estoit sa mere, Et li sires estoit ses pere. Si se porent mout esjoür De li bien veoir et ö̈r, Car il n'avoient plus d'enfanz; ${ }^{261}$
Vê, apoiado sobre seu cotovelo, Um homem imponente, deitado Sobre um lençol de seda, enquanto lia Uma donzela diante dele Um romance, não sei de quem ${ }^{260}$. Para ouvir o romance, Junto a eles viera-se recostar Uma dama. Esta era sua mãe E o senhor, seu pai.

Muito se regozijavam

Em bem vê-la e ouvi-la,

Pois não tinham outros filhos.

Se, no plano da história, o prazer experimentado pelos pais em ver e ouvir a jovem decorre sobretudo do fato de ser sua única filha, no plano da composição, fica evidenciada a importância da atividade narrativa para a produção desse prazer. Primeiramente, pois os verbos esjö̈r e ö̈r aparecem em posição de rima, criando entre ambos um forte laço que se

\footnotetext{
${ }^{260}$ Para Philippe Walter, "de cui" se refere ao assunto do romance. No entanto, traduzi-o por "de quem", baseando-me no manual de Agnès Baril, segundo o qual o pronome cui é reservado a pessoas e utilizado na maioria das vezes para exprimir posse. (BARIL, A. Manuel d'initiation à l'ancien français. Paris: Ellipses, 1998. p. 148.)

${ }^{261}$ Versos 5364-5375. (grifo meu)
} 
projeta do nível sonoro sobre o nível do significado. Além disso, há aqui um interessante efeito de mise en abyme, que chama a atenção sobre o ato de narrar. Lembremo-nos de que, no século XII, Le Chevalier au Lion era lido em voz alta diante de um público. Assim, temos um público que ouve a leitura de um romance (Yvain) no qual um público (os castelões) ouve a leitura de um romance.

Mas o prazer não deriva apenas da audição; ele pode advir igualmente da produção de um conto: "Por ce me plest a reconter" 262 , diz o narrador, que prefere, como matéria de seu poema, o rei Arthur e seus cavaleiros aos homens de seu próprio tempo.

Às vezes, há referências expícitas ao bem narrar:

Et la rë̈ne maintenant

Les noveles Calogrenant

Li reconta tot mot a mot, Que bien et bel conter li sot. ${ }^{263}$
E a rainha, imediatamente,

A história de Calogrenant

Contou-lhe toda, palavra por palavra,

Pois sabia contar muito bem.

Assim, aparentemente, conta bem aquele que conta tudo, palavra por palavra. E também aquele que não deturpa os acontecimentos, já que a fórmula "Ne vos an mantirai de $m o t^{2064}$ é recorrente. Mas os narradores sabem que não é possível contar tudo e, em suas narrativas, abundam fórmulas de brevitas, muitas vezes calando uma descrição, como o já mencionado verso "Del soper vos dirai briemant"265.

Talvez a maior demonstração da importância atribuída à palavra em Le Chevalier au Lion se situe nos versos que precedem o relato de Calogrenant. Neles, antes de iniciar sua narrativa, o cavaleiro profere um discurso que caberia perfeitamente na fala do intérprete, numa performance, pois constitui uma verdadeira preceituação sobre o modo de se comportar numa audição:

Des qu'il vos plest, or escotez!

Cuers et oroilles m'aportez,

Car parole est tote perdue

S'ele n'est de cuer entandue.

De cez i a qui la chose öent

Qu'il n'entandent, et si la löent;

Et cil n'en ont ne mes l'oüe,

Des que li cuers n'i entant mie.

As oroilles vient la parole,

Ausi come li vanz qui vole,
Posto que é de seu agrado, então escutem!

Emprestem-me seus corações e ouvidos,

Pois a palavra é toda perdida

Se não é ouvida pelo coração.

Existem aqueles que ouvem algo

Sem entender e o louvam.

Esses limitam-se ao som,

Já que o coração não compreende.

Aos ouvidos vem a palavra

Como o vento que voa,

${ }^{262}$ Verso 33: "Por isso, agrada-me contar".

${ }^{263}$ Versos 655-658.

${ }^{264}$ Verso 429: "Não lhes contarei uma só palavra de mentira".

265 Verso 250: "Sobre o jantar, falarei a vocês brevemente". 
Mes $n$ 'i areste ne demore,

Einz s'an part en mout petit d'ore,

Se li cuers n'est si esveilliez

qu'au prendre soit apareilliez;

Car, s'il le puet an son oïr

Prendre, et anclorre, et retenir,

Les oroilles sont voie et doiz

Par ou s'an vient au cuer la voiz;

Et li cuers prant dedanz le vantre

La voiz, qui par l'oroille i antre.

Et qui or me voldra entandre,

Cuer et oroilles me doit randre,

Car ne vuel pas parler de songe,

$\mathrm{Ne}$ de fable, ne de mançonge. ${ }^{266}$
Mas aí não para nem permanece.

Antes, vai-se em pouquíssimo tempo,

Se o coração não for bastante alerta

e preparado para captá-la.

Pois, se ele pode ouvir um som,

Captá-lo, guardá-lo e retê-lo,

Os ouvidos são a via e o duto

Por onde chega ao coração a voz.

O coração se apodera, no íntimo,

Da voz que pelo ouvido entra.

E quem agora quiser me compreender,

Coração e ouvidos deve me emprestar,

Pois não pretendo falar de sonho,

Nem de fábula, nem de mentira.

Essa instrução sobre a maneira adequada de se ouvir uma narrativa sugere que se trata de atividade muito séria. Trata-se do topos do audite, ou seja, uma maneira de valorizar um discurso prestes a ser proferido, o qual só poderá ser apreciado por um público atento. ${ }^{267} \mathrm{O}$ interessante é que Chrétien tenha posto o que poderia ser o discurso do narrador principal (ou do intérprete da performance) na boca de uma personagem que inicia um relato. Há aqui, mais uma vez, um interessante efeito de mise en abyme: um auditório ouve uma narrativa na qual um auditório ouve uma narrativa. E, evidentemente, o discurso dirigido por Calogrenant a seu público é válido para os ouvintes presentes no momento da leitura de Le Chevalier au Lion em voz alta.

Como afirma Adma Muhana, a narração em primeira pessoa já era conhecida desde Homero e Virgílio. Mas, na poesia antiga, esse procedimento se restringia aos protagonistas. ${ }^{268}$ Em Yvain ou le Chevalier au Lion, vemos que a posição de narrador é assumida inclusive por personagens anônimas, cujas aparições no romance são extremamente breves!

Referindo-se à prosa pastoril do século XVI, Adma Muhana afirma:

Nesta, a narração em primeira pessoa de um personagem passa a ser uma especificidade do modo de imitar, pelo qual praticamente todos os personagens se transformam em narradores. Narra o poeta, narram os protagonistas e os deuterogonistas, como se a principal ação de uns e outros fosse narrar. "Ações" propriamente ditas são as andanças dos personagens ao encontro de narradores. ${ }^{269}$

\footnotetext{
${ }^{266}$ Versos 149-172.

${ }^{267}$ JAMES-RAOUL, D. Chrétien de Troyes, la griffe d'un style. Paris: Honoré Champion, 2007. p. 177.

${ }^{268}$ MUHANA, A. A epopeia em prosa seiscentista. São Paulo: UNESP, 1997. p. 93.

${ }^{269}$ Ibid., p. 93-94. (grifos meus)
} 
Isso se assemelha muito ao poema de Chrétien. A ação una é a errância do cavaleiro, durante a qual o herói se depara com narradores/descritores de situações extraordinárias, as quais, em geral, convidam-no a algum tipo de intervenção.

No entanto, não devemos imaginar longas narrativas desenvolvidas. Nos exemplos supracitados de Lunete, do castelão e da nobre escravizada, o que temos são curtos relatos, os quais ou contêm descrições ou se confundem eles mesmos com a descrição/explicação de uma dada situação. A única narrativa mais desenvolvida e reconhecível mais claramente como tal é aquela empreendida por Calogrenant e que serve como pontapé inicial para as aventuras de Yvain. Ainda assim, nela, o descritivo se faz fortemente presente, pois temos pelo menos três grandes descrições: a do castelo do vavassalo, a do vilão guardador de touros e a da fonte da tormenta.

$\mathrm{Na}$ verdade, como afirmei em outro momento, o adolescente do texto de Pennac e a personagem de Madelaine de Scudéry teriam alguma dificuldade, na leitura de Yvain, em identificar o que é narrativo e o que é descritivo. Embora haja ações no romance, há muitas descrições de ações, o que não é sinônimo de narrativa. ${ }^{270}$ Isso já sugere a precariedade da distinção tradicional entre descrição - como ausência de ações, voltada mais para objetos e supostamente concentrada em substantivos e adjetivos - e narração - como o lugar da ação, concentrada nos verbos.

Philippe Hamon, num livro que retoma e desenvolve as ideias expostas em seu artigo de 1972, derruba definitivamente essa falsa oposição:

[...] description et narration, qu'il peut être utile, en un premier temps, d'opposer pour des raisons heuristiques, réclament sans doute d'être considérées plutôt comme deux types structurels en interaction perpétuelle (il $y$ a toujours du narratif dans le descriptif, et réciproquement - ceci pour refuser toute hiérarchisation univoque des deux types), comme deux types complémentaires à construire théoriquement, ou comme deux tendances textuelles dont il serait sans doute vain de chercher les incarnations exemplaires parfaites. [...] Il serait donc utile de poser, pour éviter de substantifier et de figer des catégories textuelles trop massivement définies, que toute description suppose un système narratif, aussi elliptique et perturbé soit-il, ne serait-ce que parce que la temporalité et l'ordre de la lecture impose à tout énoncé une orientation et une dimension transformationnelle implicite [...]. Plutôt que de description, il vaudrait donc mieux parler de descriptif, et

\footnotetext{
${ }^{270}$ Para a distinção entre descrição de ações e narrativa, remeto a ADAM, J-M; PETITJEAN, A. Prédicats fonctionnels et description d'actions. In: Le texte descriptif. Paris: Nathan, 1989. p. 152-180. Basicamente, segundo os autores, falta à descrição de ações algo fundamental para se configurar uma narrativa: a transformação de predicados definidores de um ator constante A no decorrer de um processo, ou, dito de outro modo, a transformação de uma situação inicial em situação final, passando por uma complicação e uma resolução.
} 
considérer encore une fois ce descriptif comme une "dominante" construite par certains types particuliers de textes. ${ }^{271}$

O que Hamon apresenta como uma realidade discursiva extrapolando inclusive os limites do poético e do literário verifica-se de modo especialmente claro num romance como Yvain ou le Chevalier au Lion. A inadequação da oposição entre narração e descrição salta aos olhos na medida em que o leitor sente dificuldade em determinar com precisão quais os trechos narrativos e quais os trechos descritivos no poema. Mais que isso, ainda que conseguisse fazê-lo, o leitor que costuma saltar passagens descritivas para se ater à ação, correria o risco, nesse poema, de ficar sem nada nas mãos, já que Yvain se apresenta essencialmente como uma sucessão de quadros de dominante descritiva unidos pela errância do cavaleiro. Vale já para esse poema do século XII o mesmo que se afirmou quanto à epopeia em prosa seiscentista: "cada narração de um personagem, em vez de constituir uma digressão em relação à ação principal, é parte da mesma"272. Ao que eu acrescentaria inspirado pelo trecho supracitado de Hamon e em se tratando de Yvain - "cada narração/descrição realizada por uma personagem"...

Constata-se, portanto, a importância atribuída à palavra em Yvain. Mais que remeter a uma realidade empírica, o romance parece remeter a discursos. Assim como Perrine GalandHallyn via na descrição da fabricação de objetos uma referência ao próprio fazer poético, podemos ver, na proliferação de discursos narrativos/descritivos em Yvain, uma referência à própria prática discursiva. Em ambos os casos, estamos diante da autorreferencialidade da poesia.

Essa reflexão sobre a valorização da palavra em Yvain, associada ao caráter marcadamente autorreferencial desse poema, será de grande relevância para a leitura que proporei, no terceiro capítulo, do retrato do vilão. Mas ela foi motivada por um dos aspectos apontados por Hamon como característicos do modo pelo qual a descrição se insere num conjunto textual mais amplo. Voltemos, então, por enquanto, ao artigo desse autor, para

\footnotetext{
${ }^{271}$ HAMON, P. Du descriptif. Paris: Hachette, 1993. p. 91: “[...] descrição e narração, que pode ser útil, num primeiro momento, opor por razões heurísticas, pedem sem dúvida que se as considere antes como dois tipos estruturais em interação perpétua (há sempre narrativo no descritivo e vice-versa - para rejeitar qualquer hierarquização unívoca dos dois tipos), como dois tipos complementares a construir teoricamente, ou como duas tendências textuais das quais seria vão, sem dúvida, procurar as encarnações exemplares perfeitas. [...] Seria portanto útil afirmar, para evitar substantivar e fixar categorias textuais excessivamente definidas, que toda descrição supõe um sistema narrativo, por mais elíptico e perturbado que seja, ainda que fosse porque a temporalidade e a ordem da leitura impõem a todo enunciado uma orientação e uma dimensão transformacional implícita [...]. Mais que de descrição, melhor seria então falar em descritivo, e considerar mais uma vez esse descritivo uma 'dominante' construída por certos tipos particulares de textos."' (grifos em negrito meus) Esse livro foi publicado pela primeira vez em 1981 sob o título Introduction à l'analyse du descriptif.

${ }^{272}$ MUHANA, A. A epopeia em prosa seiscentista. São Paulo: UNESP, 1997. p. 94.
} 
verificar que outros aspectos podem nos ajudar não apenas a combater uma imagem de desorganização por parte do procedimento descritivo, mas também a melhor apreciar Yvain ou le Chevalier au Lion.

Tendo percebido, como vimos, estruturas básicas por meio das quais a descrição se manifesta, Philippe Hamon passa então a perguntar-se — sempre a partir de Zola — sobre a existência de marcas introdutoras de descrições. Ele de fato as identifica e as agrupa em quatro categorias: 1. meios transparentes; 2. personagens-tipo; 3. cenas-tipo; 4. motivações psicológicas, tais como a curiosidade, o interesse, o prazer estético, a fascinação, entre muitas outras. $^{273}$

Em Yvain ou le Chevalier au Lion também é possível perceber que as inserções de descrições são preparadas. Mas, evidentemente, as marcas introdutoras de descrições num poema do século XII não são necessariamente as mesmas de um romance naturalista do século XIX. Assim, já vimos que, embora Le Goff afirme que as maravilhas se revelam primordialmente ao olhar, em Yvain esse sentido, ainda que presente, é suplantado pela audição: veem-se coisas, mas, sobretudo, ouvem-se relatos e descrições de coisas. Mesmo a apreciação do mais visual dos espetáculos é precedida pela audição - referência indireta à oralidade da poesia medieval? - : antes de ver a fonte mágica e as maravilhas a ela relacionadas, Yvain ouve sua descrição por parte de Calogrenant, o qual, por sua vez, antes de vê-las, também ouvira sua descrição por parte do vilão. Do mesmo modo, é primeiramente "un cri mout dolereus et haut" ${ }^{274}$ que chama a atenção de Yvain para a luta entre o leão e a serpente. Portanto, em Yvain, mais importantes que os meios transparentes - janelas, portas abertas -, como no caso de Zola, são as situações que permitem um encontro e, por conseguinte, um diálogo. Quando este parece impossível, cria-se-lhe uma abertura... literalmente! Assim, um lugar-comum da poesia do período ${ }^{275}$ é a fenda num muro ou parede, através da qual duas personagens separadas podem se comunicar. Foi assim que Lunete, aprisionada numa capela, pôde expor seu infortúnio a Yvain.

Quanto a personagens-tipo, Hamon mostra que, no caso de Zola, temos: o pintor, o espião, a fofoqueira, o técnico, entre outros, funcionando como personagens transmissores de um saber. Hamon menciona também cenas-tipo, que propiciariam a introdução de uma descrição por oferecer uma pausa na ação principal e uma situação favorável à observação de

\footnotetext{
${ }^{273}$ HAMON, P. Qu'est-ce qu'une description? Poétique, Paris, n. 12, p. 473, 1972.

${ }^{274}$ Verso 3346: "um grito muito alto e doloroso".

275 Ele aparece também, por exemplo, numa narrativa do século XIII, Aucassin et Nicolette, permitindo a Nicolette passar a cabeça inteira por uma fenda na torre que aprisionava seu amado Aucassin. Esse motivo já aparece nas Metamorfoses, de Ovídio, na história do amor igualmente proibido de Píramo e Tisbe. (WALTER, P. Notes. In: AUCASSIN et Nicolette. Paris: Gallimard, 1999. p. 187-201, nota 2, relativa à p. 75.)
} 
algo: a chegada a um encontro com antecedência, um passeio, o olhar através de uma janela ou a partir de um lugar elevado, entre outras.

Em Yvain, ao lado do cavaleiro andante, evidentemente, a personagem-tipo por excelência e que narra/descreve ou dá margem a narrações/descrições é encarnada pela vítima de um infortúnio. Em sua errância, o herói encontra personagens que lhe expõem sua situação infeliz ou mesmo desastrosa, o que o move no sentido de ajudá-las. Há também o vilão, que não passa por nenhuma dificuldade nem depende do herói, mas indica-lhe, por meio de uma descrição, uma aventura. Esse tipo de personagem - um vilão e/ou uma criatura horrenda que indica uma aventura, um caminho ou outra coisa procurada por seu interlocutor aparece em outras narrativas do período.

Do que foi dito, depreende-se que uma cena-tipo se destaca: o encontro, o qual pode assumir duas modalidades. A primeira são as conjunções efetuadas durante a cavalgada diurna (vilão, leão, Lunete aprisionada, mensageira da irmã caçula de Espinho $\mathrm{Negro}^{276}$ ). A segunda, a interrupção da jornada e a hospedagem do herói num castelo, para passar a noite ou recuperar-se de ferimentos (vavassalo, dama de Norison $^{277}$, vítimas de Harpin, tecelãs do Castelo da Pior Aventura).

Finalmente, como "motivações psicológicas" para a descrição, destacam-se a curiosidade (insistência para que Calogrenant prossiga em seu relato), o interesse em ajudar o outro (Yvain insiste junto àqueles que sofrem para lhe explicarem as causas de seu sofrimento), o prazer proporcionado por uma grande beleza (a fonte comolocus amoenus) ou o horror proporcionado por uma grande feiura (o vilão), enfim, o fascínio despertado pelo extraordinário (o vilão, a fonte como locus amoenus e, sobretudo, como locus horridus, a luta entre o leão e a serpente cuspidora de fogo).

Vimos até aqui como a descrição se insere numa unidade textual maior e o modo como isso se dá particularmente em Yvain. Passemos agora a examinar como Hamon considera seu funcionamento interno.

O autor chama a atenção para a previsibilidade existente em todo processo de leitura, mas destaca sua natureza específica quando se trata de uma descrição:

\footnotetext{
${ }^{276}$ Com a morte do senhor de Espinho Negro, sua filha mais velha se apossa de tudo, inclusive do pouco que caberia à irmã mais nova. Esta, desesperada, solicita e recebe a ajuda de Yvain, ao passo que a mais velha consegue obter a ajuda de Gauvain, o que levará os dois amigos a se enfrentarem, sem se reconhecerem, no final do romance.

277 Graças a quem Yvain é curado de sua loucura e que, por sua vez, recebe a ajuda do herói contra um inimigo, o conde Alier.
} 
La description ne fait certainement pas appel à la même "conscience linguistique" (de l'auteur ou du lecteur) que la narration en ce qui concerne son fonctionnement intérieur. On passe d'une prévisibilité logique, celle du récit où la notion de corrélation et de différence sont primordiales (une ouverture de porte appelle une fermeture de porte, un départ appelle un retour, un mandement appelle une acceptation ou un refus, une disjonction d'actants appelle une conjonction d'actants etc.) à une prévisibilité lexicale où la notion d'inclusion et de ressemblance l'emportent (le terme rose appellera par contiguïté métonymique: bouquet, pétale, jardin, fleur etc. ou: pureté, virginité, candeur etc. par métaphore institutionnalisée; ou rosier, roseraie, rosière etc. par dérivation; ou: arrose, pose, chose, ose... par ressemblance phonétique). ${ }^{278}$

No caso do retrato do guardador de touros, ocorre algo interessante. Evidentemente, ao introduzir o tema-título "vilão", o texto gera uma previsibilidade lexical. Conhecendo-se o modelo medieval, sabe-se que a descrição se iniciará pela cabeça e evocará cabelos, testa, sobrancelhas, olhos, nariz, boca, etc., conforme veremos adiante. Mas, para além disso, o que vemos é um acúmulo de elementos lexicais inespesperados no retrato de um ser humano: cavalo, elefante, coruja, gato, lobo, javali. Assim, os elementos esperados (partes da cabeça) se fazem presentes, mas, ao serem deslocados da esfera do humano para a esfera animal por meio de comparações, produzem uma figura absolutamente surpreendente, imprevisível e dificilmente representável.

Segundo Philippe Hamon, o autor dispõe de alguns recursos "pour doser cette prévisibilité et régler l'homogénéité sémantique de la description". ${ }^{279}$ A partir disso, Hamon considera a existência de seis tipos de descrições, dos quais apenas dois nos interessam aqui.

O primeiro deles diz respeito a descrições cujo campo lexical é demasiadamente técnico, o que pode torná-las ilegíveis. Para evitar esse risco, o vocabulário técnico tenderá a ser qualificado, adjetivado pelo autor, numa tentativa de contrabalançar sua obscuridade: "La comparaison, la paraphrase, l'apposition explicative, la métaphore anthropomorphique seront

\footnotetext{
${ }^{278}$ HAMON, P. Qu'est-ce qu'une description? Poétique, Paris, n. 12, p. 474, 1972: “A descrição certamente não solicita a mesma 'consciência linguística' (do autor ou do leitor) que a narração no que concerne a seu funcionamento interior. Passa-se de uma previsibilidade lógica - a da narrativa, em que a noção de correlação e de diferença são primordiais (uma abertura de porta chama um fechamento de porta, uma partida chama um retorno, uma ordem chama um aceite ou uma recusa, uma disjunção de actantes chama uma conjunção de actantes, etc.) - a uma previsibilidade lexical, em que as noções de inclusão e de semelhança predominam (o termo rosa chamará por contiguidade metonímica: buquê, pétala, jardim, flor, etc.; ou: pureza, virgindade, candura, etc., por metáfora institucionalizada; ou roseira, roseiral, roseirista, etc. por derivação; ou: tosa, glosa, prosa, dosa... por semelhança fonética)." (grifos em negrito meus)

${ }^{279}$ Ibid., p. 477: "dosar essa previsibilidade e regular a homogeneidade semântica da descrição".
} 
les types de prédicats les plus employés pour sémantiser le lexique technique de la description" 280 .

No caso do retrato do vilão, a comparação entra, aparentemente, como um fator de facilitação da comunicação, uma vez que Calogrenant se lança à impossível tarefa de descrever algo, segundo ele, indescritível. Mas trata-se da alegação de uma personagem no plano da história. No plano do discurso ${ }^{281}$, constata-se que os vocábulos empregados não são técnicos ou incompreensíveis: cabeça, orelhas, olhos, nariz, boca, dentes. É justamente o acréscimo e o acúmulo de predicados que dificultam a apreensão dessa figura. Todos hão de concordar que uma recomposição mental do vilão a partir dessa descrição exige um bom esforço de imaginação! Assim, nesse retrato, a comparação desempenha uma função justamente oposta àquela que desempenha, segundo Hamon, numa descrição realista.

No segundo tipo, ao contrário, tanto o tema introdutor da descrição quanto o paradigma lexical a ele associado são facilmente reconhecíveis. Hamon cita justamente o exemplo de um retrato, que introduz a série "cabelos, olhos, nariz, roupas, etc.". Nesse caso, em que o horizonte de expectativas é restrito e a previsibilidade é acentuada, corre-se o risco da banalidade. A solução é a introdução de predicados metafóricos o mais distantes possível, semanticamente, do tema e subtemas aos quais se aliam. A ideia é que a série de predicados qualificativos e/ou funcionais possua um baixo grau de previsibilidade e, para isso, serão compostos por um vocabulário técnico, especializado, pouco conhecido. Pela mesma razão, “l'animé sera décrit par référence à l'inanimé, le concret par l'abstrait, le naturel par le culturel, etc. [...] La description se fait ici proche du fantastique (brouiller le connu par l'inconnu)". 282

No caso do vilão, temos o humano descrito por meio de referências ao não humano. O interessante nesse retrato é que tanto seu tema e subtemas (vilão, cabeça, olhos, orelhas, etc.) quanto os predicados a eles relacionados (as comparações com animais como a coruja, o gato e o cavalo) são conhecidos, mas, por sua contiguidade, formam um todo surpreendente e extraordinário, compõem um desconhecido.

Isso sugere um questionamento: será que, em vez de considerar - como fazem vários críticos, alguns baseando-se em supostas crenças do período - o guardador de touros uma

\footnotetext{
${ }^{280}$ HAMON, P. Qu'est-ce qu'une description? Poétique, Paris, n. 12, p. 478, 1972: “A comparação, a paráfrase, a aposição explicativa, a metáfora antropomórfica serão os tipos de predicados mais empregados para semantizar o léxico técnico da descrição".

${ }^{281}$ Ver a nota 189 na página 83 deste trabalho.

${ }^{282}$ HAMON, P., op. cit., p. 478-479: "o animado será descrito por referência ao inanimado, o contreto pelo abstrato, o natural pelo cultural, etc. [...] A descrição se faz aqui próxima do fantástico (baralhar o conhecido pelo desconhecido)". (grifo meu)
} 
personagem feérica ou mitológica, por seu caráter monstruoso de criatura compósita, não deveríamos ler essa descrição simplesmente como o retrato ricamente trabalhado de um homem? O que para alguns é indício de um caráter feérico da personagem não deveria ser visto antes como uma estratégia discursiva para evitar a banalidade de uma descrição de alto teor de previsibilidade?

Voltarei a essa questão no próximo capítulo. Por hora, limito-me a enfatizar que, assim como - por meio do estudo de suas funções - constatamos a impropriedade de se atribuir um caráter gratuito ou supérfluo à descrição, diante das teorizações de Philippe Hamon e Jean-Michel Adam - reveladoras de um funcionamento complexo da descrição - , torna-se risível taxá-la de caótica e ilimitada, fruto de um capricho autoral.

Hamon vai ainda mais longe ao romper a oposição tradicional entre narração e descrição e ao elaborar, como vimos, um conceito de descritivo, entendido como uma dominante construída por certos tipos de textos, um movimento global, do qual a descrição seria apenas um momento localizado. ${ }^{283}$

Minha errância conduziu-me da floresta de Broceliande - onde se passam as aventuras de Yvain - a uma reflexão sobre a descrição e o descritivo. Mas minha motivação inicial consistia em meu interesse pelos elementos encontrados naquela floresta e percebidos então como maravilhas. Assim, retornemos - há um retorno possível? - ao ponto de partida...

\footnotetext{
${ }^{283}$ HAMON, P. Du descriptif. Paris: Hachette, 1993. p. 241.
} 


\section{CAPÍTULO 3: DE VOLTA À TÁVOLA REDONDA}

Os cavaleiros de Arthur, depois de um período de errância, retornam à corte, seu ponto de partida, e, em torno à Távola Redonda, narram suas aventuras. Mas o retorno é apenas aparente, pois já não são mais os mesmos.

Do mesmo modo, se retomo agora o maravilhoso, depois de uma errância pelo poema de Chrétien e por textos teórico-críticos, já não o vejo sob o mesmo prisma.

\subsection{Ouvir para crer: o maravilhoso dos historiadores}

No capítulo 2, vimos com o historiador Jacques Le Goff que o maravilhoso se definiria como um conjunto de seres, fenômenos e objetos fortemente surpreendentes por sua raridade. Eles podem pertencer ao domínio do sobrenatural - seja ele mágico-diabólico ou divino-miraculoso - ou do natural. Para afirmar o caráter natural do maravilhoso, Le Goff se baseia na definição proposta pelo inglês Gervásio de Tilbury, na enciclopédia elaborada por ele para o imperador Oto IV de Brunswick, Otia imperialia (Para entretenimento do imperador), no início do século XIII, e cuja terceira parte é uma coletânea de maravilhas ${ }^{284}$ : "Par merveilles, nous entendons ce qui échappe à notre compréhension, bien que naturel: ce qui fait la merveille, c'est notre impuissance à rendre compte de la cause d'un phénomène"285.

Esclareçamos, no entanto, o tipo de fenômeno que Gervásio considera "natural”. Logo na sequência de sua definição, ele fornece alguns exemplos, entre os quais figura a salamandra, não o anfíbio conhecido de nossos zoólogos, mas o ser fabuloso assim definido: "la salamandre vit dans le feu et, quoique la nature du feu soit de consumer tout ce qu'il touche, elle se nourrit du feu sans en être consumée"286.

Outra dessas maravilhas "naturais" mostra mulheres vivendo próximas ao Mar Vermelho:

${ }^{284}$ LE GOFF, J. Maravilhoso. In: ; SCHMITT, J.-C. Dicionário temático do Ocidente medieval. São Paulo: EDUSC, 2002. v. 2. p. 108.

${ }^{285}$ GERVAIS DE TILBURY. Le livre des merveilles. Paris: Les Belles Lettres, 2004. p. 20: "Por maravilhas, entendemos aquilo que escapa à nossa compreensão, ainda que natural: o que faz a maravilha é nossa impotência de dar conta da causa de um fenômeno".

${ }^{286}$ Ibid., p. 20: "a salamandra vive no fogo e, ainda que a natureza do fogo seja de consumir tudo o que toca, ela se nutre do fogo sem ser consumida por ele". 
"Vers ces mêmes lieux, il y a d'horribles femmes qui ont une barbe jusqu'aux seins. Elles ont la tête plate, sont vêtues de peaux et pratiquent la chasse; en guise de chiens de chasse, elles élèvent des bêtes qui ressemblent à des léopards.

Il $\mathrm{y}$ a près de là des montagnes où naissent des femmes ayant des dents de sanglier, une chevelure longue jusqu'aux talons et par derrière une queue de vache: leur taille est de sept pieds, leurs corps velu comme celui du chameau. $" 287$

Essas mulheres lembram, sob alguns aspectos, o vilão de Le Chevalier au Lion. As do primeiro grupo têm com ele em comum o fato de possuírem uma cabeça achatada e de se cobrirem com peles de animais. Além disso, assim como ele guarda touros "selvagens como leopardos", elas criam animais que parecem leopardos. Com as mulheres do segundo grupo, os pontos comuns são os dentes de javali e a pilosidade. Na verdade, mais preciso seria afirmar que essas descrições lembram aquele retrato, já que, em vez de uma parecença referencial, temos uma paridade de discursos. ${ }^{288}$

Em sua História da feiura, Umberto Eco também se refere a criaturas maravilhosas e traz abundante iconografia. Veem-se, por exemplo, animais fabulosos como o unicórnio e o dragão. Veem-se também homens sem cabeça, mas com o rosto estampado no peito; outros, com uma perna só e um pé enorme, à sombra do qual podem se repousar, bastando para isso deitarem-se e erguerem a perna. ${ }^{289}$

Diante de seres com tais características, como entender o caráter "natural" das maravilhas? Le Goff afirma que o maravilhoso compõe um sistema com o mágico e o miraculoso. Uma vez que o milagre pertence ao âmbito divino e a magia — essencialmente - ao diabólico, resta ao maravilhoso um lugar intermediário entre as duas esferas sobrenaturais: o plano terreno. ${ }^{290}$ Nele, agem as outras duas forças, mas, ao considerar os fenômenos maravilhosos como "naturais", Gervásio de Tilbury nega-lhes uma origem sobrenatural - divina ou diabólica. Evidentemente, a própria natureza é um produto da

\footnotetext{
${ }^{287}$ GERVAIS DE TILBURY. Le livre des merveilles. Paris: Les Belles Lettres, 2004. p. 86: "Por essas mesmas bandas, há horríveis mulheres que possuem uma barba até os seios. Elas têm a cabeça achatada, vestem-se com peles e praticam a caça; como cães de caça, elas criam animais que parecem leopardos. // Perto dali, há montanhas onde nascem mulheres com dentes de javali, uma cabeleira até os calcanhares e, atrás, um rabo de vaca: sua altura é de sete pés, seu corpo peludo como o do camelo".

${ }^{288}$ A leitura desse trecho aponta para o quanto há de tópico na descrição do vilão. A comparação dessas e de outras representações da feiura renderia um estudo interessante, mas, não sendo possível realizá-la nos limites deste trabalho, deixá-la-ei para uma provável etapa de aprofundamento desta pesquisa.

${ }^{289}$ ECO, U. Monstros e portentos. In: ECO, U. (Org.). História da feiura. Rio de Janeiro: Record, 2007. p. 106-129.

${ }^{290}$ LE GOFF, J. Héros et merveilles du Moyen Âge. Paris: Seuil, 2005. p. 10.
} 
criação divina $^{291}$, mas, ao operar um milagre, Deus estaria subvertendo as leis da natureza ${ }^{292}$, ao passo que as maravilhas fariam parte dela.

Numa de suas entrevistas, Le Goff afirma que, para os homens medievais, o maravilhoso é de fato real. À pergunta "Os homens da Idade Média creem então realmente nessas lendas e maravilhas?", o historiador responde: "Minha resposta é muito firme: sim, eles creem". 293

Outra historiadora, Laura de Mello e Souza, trabalhando com o contexto do Renascimento e das grandes navegações, aborda também a questão da credibilidade das maravilhas e afirma sobre o que chama o "início da Época Moderna”:

Os monstros povoavam a vida cotidiana dos europeus, e narrativas de viagens reais relatavam acontecimentos inverossímeis e descreviam seres fantásticos. Os relatos de nossos primeiros cronistas dão exemplo disso, assim como o diário e as cartas de Colombo, em que se evidencia a decepção por não encontrar, no Caribe, sereias tão belas como as que povoavam seu universo imaginário. Para nós, o extraordinário é que as tenha encontrado e visto: via-se então o que, $a$ priori, tinha-se concebido mentalmente ou, então, via-se o que se ouvira dizer. Lucien Febvre, pai da história das sensibilidades e das mentalidades, mostrou que, no século XVI, nada parecia impossível aos homens, fadados a acreditarem: a descrença não fazia parte do universo mental do homem de então. ${ }^{294}$

Umberto Eco parece, em alguns momentos, caminhar na mesma direção, como quando comenta o encontro de Marco Polo com rinocerontes, numa de suas viagens:

Tratava-se, para ele, de animais nunca dantes vistos, e como sua cultura já lhe oferecia a ideia do unicórnio como quadrúpede com um único chifre sobre o focinho, decide que está vendo um unicórnio. Porém, como é um cronista honesto e aplicado, apressa-se a explicar que estes são unicórnios muito estranhos, diferentes da imagem tradicional: não são brancos e esbeltos, mas têm "pelos de búfalo e patas como leonfantes"; o chifre é preto e desgracioso, a língua espinhosa, a cabeça semelhante à de um javali. E conclui que não somente o animal em questão "é besta muito feia de se ver", mas também "não é que, como se diz por aqui, se deixe prender por uma donzela ${ }^{295}$, muito pelo contrário".

\footnotetext{
${ }^{291}$ LE GOFF, J. Maravilhoso. In: .; SCHMITT, J.-C. Dicionário temático do Ocidente medieval. São Paulo: EDUSC, 2002. v. 2. p. 106.

${ }^{292}$ LE GOFF, J. Héros et merveilles du Moyen Âge. Paris: Seuil, 2005. p. 10.

${ }^{293}$ HÉROS et merveilles du Moyen Âge. Les collections de l'histoire. Paris: Société d'Éditions Scientifiques, n. 36, p. 12, juil.-sept. 2007.

${ }^{294}$ SOUZA, L. M. A feitiçaria na Europa moderna. São Paulo: Ática, 1987. p. 7. (grifos em negrito meus)

${ }^{295}$ Referência ao discurso segundo o qual, para se capturar um unicórnio, devia-se colocar uma virgem sentada sob uma árvore, pois o animal, não resistindo ao perfume da virgindade, viria deitar a cabeça em seu colo, ficando, assim, vulnerável. (ECO, U., org. História da feiura. Rio de Janeiro: Record, 2007. p. 120.)

${ }^{296}$ Ibid., p. 127. (grifo meu)
} 
Assim, o maravilhoso estaria vinculado a um conjunto de crenças compartilhadas pelos homens de uma certa cultura e de uma certa época.

\subsection{O sobrenatural como tema: o maravilhoso da crítica literária}

Passando do campo da historiografia para o campo da crítica literária, verifica-se que também a discussão dos especialistas em literatura passa em grande medida por uma questão de crença, quando o assunto é o maravilhoso.

Em 1982, Daniel Poirion publica um pequeno livro, aclamado pela crítica, no qual define o fenômeno maravilhoso como "la manifestation d'un écart culturel entre les valeurs de référence, servant à établir la communication entre l'auteur et son plublic, et les qualités d'un monde autre ${ }^{\text {,297 }}$. Para ele, o maravilhoso não se apresenta exatamente como crível para seu público, mas como algo que já o teria sido alhures ou outrora. ${ }^{298}$ A ideia de uma crença em maravilhas, portanto, continua presente, mas apenas deslocada para um outro espaço e/ou um outro tempo. Assim, o maravilhoso implicaria necessariamente uma ideia de alteridade. Para lidar com ela, Poirion aproxima-se de duas áreas: a história da cultura e a psicanálise. A história da cultura seria necessária na medida em que Poirion vê o maravilhoso medieval como fruto de um distanciamento entre culturas diversas ou entre diferentes níveis de uma mesma cultura. Quanto à psicanálise, embora o autor não a proponha explicitamente como instrumento de interpretação, fica nítida sua participação no modo como Poirion percebe o maravilhoso:

En effet, la signification de ces thèmes et de ces images qui viennent ainsi hanter notre littérature est à chercher dans le subconscient qui reste en marge des sociétés. Comme dans les rêves, les constructions du désir interdit prennent dans la littérature le masque de l'étrangeté. Mais cette étrangeté est complice de notre plus secrète intimité. Ce sont ainsi les cultures étrangères qui fécondent l'imagination et aident à penser la vie, la sexualité et la mort. ${ }^{299}$

\footnotetext{
${ }^{297}$ POIRION, D. Le merveilleux dans la littérature française du Moyen Âge. $2^{\mathrm{e}}$ ed. Paris: P.U.F., 1995. p. 3-4: “a manifestação de uma distância cultural entre os valores de referência, servindo a estabelecer a comunicação entre o autor e seu público, e as qualidades de um mundo outro".

298 Ibid., p. 5.

${ }^{299}$ Ibid., p. 6: "Com efeito, o significado desses temas e dessas imagens que assim revisitam frequentemente nossa literatura deve ser procurado no subconsciente que fica à margem das sociedades. Como nos sonhos, as construções do desejo proibido tomam na literatura a máscara da estranheza. Mas essa estranheza é cúmplice de
} 
Percebe-se, nesse trecho, a onipresença de um campo lexical associado à psicanálise. Mas o que nos interessa sobretudo é observar os vocábulos "temas" e “imagens", que aparecem logo na primeira linha da citação. Eles indicam que, seja pelo viés da história cultural, seja pelo viés da psicanálise, a abordagem de Poirion é essencialmente temática.

De fato, no capítulo em que aborda o conjunto da obra de Chrétien, Poirion elenca objetos mágicos — como anéis e filtros amorosos - e personagens "do Outro Mundo" como fadas, anões e gigantes. Nesse capítulo, a questão da crença reaparece, mesclada a elementos de mitologia. Assim, para Poirion, o nome Lunete sugere uma relação com a lua, “comme pour Diane, que le Moyen Âge croyait avoir été une fée"300. O termo motivo está em toda parte e Poirion se preocupa com substratos míticos desses motivos.

Essa tendência a colocar o problema do maravilhoso em termos temáticos impera em meio à bibliografia especializada. Em Les monstres dans la littérature allemande du Moyen Âge (1150-1350), publicado em 1982, em três volumes, Claude Lecouteux estuda mais de cento e cinquenta gigantes que reúne em quatro grandes famílias:

1. les vrais géants; solitaires, velus, cruels, bestiaux;

2. les faux géants: chevaliers grandis par exagération épique ou goût du merveilleux, géants rationalisés;

3. les géants exotiques, venant de Malprose, de Canaan ou de Babylone;

4. les géants hérités de l'Antiquité classique et de la Bible. ${ }^{301}$

Portanto, temos a impressão de que, para Lecouteux, o maravilhoso se constitui por um conjunto de temas, dos quais ele elege um para interpretar. Em sua interpretação, ou seja, na busca do sentido oculto dessas figuras, ele chega a associar diretamente poesia e realidade, ao considerar, como vimos, o gigante Harpin de la Montagne a literalização de um tipo social - o camponês enriquecido —, representado negativamente. Assim, para esse autor, o maravilhoso poderia assumir uma função de crítica social.

Numa obra considerada clássica ${ }^{302}$, Laurence Harf-Lancner pesquisa as fadas na Idade Média. Seu objetivo é estudar o nascimento de "uma nova figura mítica" "de origem

nossa mais secreta intimidade. Assim, são as culturas estrangeiras que fecundam a imaginação e ajudam a pensar a vida, a sexualidade e a morte". (grifos meus)

${ }^{300}$ POIRION, D. Le merveilleux dans la littérature française du Moyen Âge. $2^{\mathrm{e}}$ ed. Paris: P.U.F., 1995. p. 73: "como para Diana, que a Idade Média acreditava ter sido uma fada". (grifo meu)

${ }^{301}$ LECOUTEUX, C. Harpin de la Montagne. Cahiers de civilisation médiévale, Poitiers, n. 30, p. 221, $1987:$ " 1. os verdadeiros gigantes; solitários, peludos, cruéis, bestiais; 2. os falsos gigantes: cavaleiros engrandecidos por exagero épico ou gosto pelo maravilhoso, gigantes racionalizados; 3. os gigantes exóticos, vindos de Malprosa, de Canaã ou da Babilônia; 4. os gigantes herdados da Antiguidade clássica e da Bíblia". 
folclórica". ${ }^{303}$ A autora recorre, portanto, ao folclore e analisa inúmeras narrativas, atentando para sua estrutura. Ela conclui que os contos tradicionais já esboçavam uma tipologia das fadas, que, ao passar ao domínio literário, concentrou-se nas figuras de Morgana e Melusina como arquétipos opostos — respectivamente negativo e positivo — da feminilidade. "Mito", "folclore"... estamos diante de temáticas caras à história cultural.

A preocupação com temas fica evidente na publicação, em 2006, das atas de um colóquio realizado em 2002, justamente em torno dos motivos maravilhosos ao longo dos séculos de literatura francófona. ${ }^{304}$

Um desses trabalhos é assinado por aquele que talvez seja a maior autoridade da atualidade no que se refere ao maravilhoso: Francis Dubost. Nele, o autor dedicou-se aos motivos relativos à vida paradoxal, ou seja, uma vida anormalmente prolongada ou uma morte viva: cadáveres animados, almas do outro mundo, ressurreições, entre outros. ${ }^{305}$ Aqui surge novamente a referência às crenças do período: "Cette histoire [do maravilhoso e do fantástico] est intimement liée aux croyances et superstitions qui touchent au monde surnaturel, et la mort est la porte du surnaturel”,306.

Em sua tese de Doctorat d'État, Dubost já havia abordado vários "temas" maravilhosos: o lobisomem, o gigante, o centauro, etc. ${ }^{307}$ Mas seu trabalho não consiste em mera catalogação de motivos, nem numa tentativa de interpretá-los ou de agrupá-los em arquétipos relacionados à afetividade humana. Trata-se antes da defesa da existência de um “fantástico medieval”. Contra possíveis confusões, o autor alerta: “ce n'est pas le fantastique en tant que genre qui fait l'objet de ce travail, mais le fantastique en tant que forme de l'imaginaire dont l'expression littéraire relève d'une esthétique de la peur". ${ }^{308}$

Quanto a seu procedimento, o autor afirma:

La démarche part des textes pour remonter vers les données culturelles et mythiques qui les enforment. Elle nous conduira à situer le fantastique par

\footnotetext{
${ }^{302}$ HARF-LANCNER, L. Les fées au Moyen Âge. Paris: Honoré Champion, 1984.

303 Ibid., p. 8-9.

304 GINGRAS, F. (Dir.). Une étrange constance: les motifs merveilleux dans les littératures d'expression française du Moyen Âge à nos jours. Québec: Les Presses de l’Université Laval, 2006.

305 DUBOST, F. La vie paradoxale: la mort vivante et l'imaginaire fantastique au Moyen Âge. In: GINGRAS, op. cit., p. 11-38.

306 Ibid., p. 12: "Essa história [do maravilhoso e do fantástico] está intimamente ligada às crenças e superstições concernentes ao mundo sobrenatural, e a morte é a porta do sobrenatural".

307 DUBOST, F. Aspects fantastiques de la littérature narrative médiévale (XII ${ }^{e}$-XIII ${ }^{e}$ siècles): L'Autre, l'Ailleurs, l'Autrefois. Paris: Honoré Champion, 1991.

308 Ibid., p. 9: "não é $o$ fantástico como gênero o objeto deste trabalho, mas o fantástico como forma do imaginário cuja expressão literária pertence a uma estética do medo".
} 
rapport à l'expérience de la terreur surnaturelle, et surtout par rapport à l'expression ritualisée ou socialisée qu'en donne la littérature. ${ }^{309}$

Por mais que o trabalho de Dubost possua um maior grau de profundidade e procure atentar mais para questões propriamente literárias, percebe-se que partilha com os demais críticos uma grande preocupação com dados culturais exteriores ao próprio texto poético. Assim, seu alvo não é a poesia, mas uma forma do imaginário, relacionada a uma experiência (a do terror sobrenatural). Dito de outro modo, o autor não parece se interessar por um efeito provocado pela poesia, mas sim por uma experiência de terror preexistente a ela e da qual o texto poético seria a expressão.

Vimos, portanto, que a crítica literária relativa ao maravilhoso aproxima-se muito dos interesses da história cultural (folclore, mito, crenças) por meio de suas abordagens temáticas, baseadas no estudo de motivos.

Outro traço comum à maioria desses críticos é o fato de considerar o maravilhoso algo estreitamente relacionado ao sobrenatural. Assim, lê-se em Dubost: "Le motif merveilleux se caractérise par la présence d'au moins un élément surnaturel dans la séquence minimale constituée par le couple thème/prédicat" ${ }^{, 310}$. Laurence Harf-Lancner, diferentemente de Le Goff, considera o miraculoso, o mágico (satânico) e o maravilhoso três registros do sobrenatural medieval, sendo que o último - no qual se encontrariam as fadas - distinguirse-ia dos primeiros apenas por seu caráter não cristão. ${ }^{311}$ Quanto ao conjunto da obra de Chrétien de Troyes, Daniel Poirion manifesta-se contrário à posição — partilhada por Dubost - segundo a qual o autor de Yvain, por meio da ironia, tomaria uma distância crítica em relação ao maravilhoso. Considerando alguns traços que lhe permitiriam pensar numa poética da maravilha, Poirion conclui que esta se aproxima mais de uma poética do sonho que de uma tentativa de desmistificação. Em vez de ironia, o autor vê em Chrétien um jogo com a dúvida, promotor de uma hesitação entre o natural e o sobrenatural. Interessante observar que, nessa análise, o campo lexical empregado por Poirion remete, direta ou indiretamente, ao

\footnotetext{
${ }^{309}$ DUBOST, F. Aspects fantastiques de la littérature narrative médiévale (XII ${ }^{e}$-XIII siècles): L'Autre, l'Ailleurs, l'Autrefois. Paris: Honoré Champion, 1991. p. 8: "O caminho parte dos textos para remontar aos dados culturais e míticos que lhes dão forma. Ele nos conduzirá a situar o fantástico em relação à experiência do terror sobrenatural e, sobretudo, em relação à expressão ritualizada ou socializada que dela dá a literatura". (grifos meus)

${ }^{310}$ DUBOST, F. La vie paradoxale: la mort vivante et l'imaginaire fantastique au Moyen Âge. In: GINGRAS, F. (Dir.). Une étrange constance. Les motifs merveilleux dans les littératures d'expression française du Moyen Âge à nos jours. Québec: Les Presses de l'Université Laval, 2006. p. 17: "O motivo maravilhoso se caracteriza pela presença de ao menos um elemento sobrenatural na sequência mínima constituída pela dupla tema/predicado". (grifo meu)

${ }^{311}$ HARF-LANCNER, L. Les fées au Moyen Âge. Paris: Honoré Champion, 1984. p. 7-8.
} 
sobrenatural: misterioso, incerteza, inexplicável, sobrenatural, encantamento, fenômenos estranhos, poder oculto, ilusões, sonho, alucinação, revelação privilegiada.

Assim, a maioria dos estudos desse tipo, por mais atraentes que possam ser - e, de fato, muitos o são ${ }^{312}$ - dizem mais aos interessados em folclore, mitologia, história cultural ou história do imaginário ${ }^{313}$ — do que aos interessados propriamente no fenômeno poético. Desse modo, distanciam-se de meu objetivo, pois, ao perceber uma associação entre maravilhoso e descritivo, fui levado a me preocupar primordialmente com o que Hamon chamou de um "efeito de poesia".

\subsection{O monstro da poesia}

No capítulo 2, vimos que uma das funções do retrato do vilão em Yvain ou le Chevalier au Lion consistia em maravilhar o público, tanto os ouvintes das leituras em voz alta do século XII, quanto os leitores silenciosos modernos. No mesmo capítulo, afirmei que esse recorte permitiria refletir sobre as relações entre o maravilhoso e o descritivo. No início da pesquisa, movia-me o interesse pelo maravilhoso, compreendido a partir da definição proposta por Le Goff. Partilhava também da abordagem da maioria dos críticos literários dedicados ao assunto, isto é, via no vilão um motivo maravilhoso por suas supostas relações com a esfera do sobrenatural: seu caráter compósito, seu domínio aparentemente mágico sobre os touros selvagens, sua posição de guia da fonte da tormenta.

Tendo estudado teóricos contemporâneos do descritivo, já os confrontando com o poema de Chrétien, proponho agora revisitarmos o retrato do vilão, para finalmente verificar, por um lado, como ele nos permite pensar as relações entre maravilhoso e descritivo e, por outro, sob quais aspectos a jornada realizada modificou meu olhar sobre ele. Mas, para essa modificação, contribuíram também as leituras de algumas passagens de dois tratados de Retórica da Antiguidade que não mencionei até agora. Assim, antes de abordarmos o retrato

\footnotetext{
${ }^{312}$ Não se trata, portanto, de desqualificar os trabalhos de Poirion, Harf-Lancner ou Dubost, mas de assinalar meu distanciamento em relação a eles por uma diferença de objetivos, como ficará claro na sequência.

313 Adoto o termo imaginário no sentido empregado pelos historiadores da chamada "nova história", ou seja, como um conjunto de imagens que exterioriza certos sentimentos, ignorâncias, expectativas, desejos. O imaginário possui um caráter histórico, social e coletivo. Não é o conjunto das "imaginações” individuais, mas, antes, o conjunto dos parâmetros que permitem, por exemplo, certas crenças. Para um alargamento dessa definição, remeto a: FRANCO JÚNIOR, H. Cocanha: a história de um país imaginário. São Paulo: Companhia das Letras, 1998. p. 16-18; e a SCHMITT, J.-C. A imaginação eficaz. Signum, São Paulo, n. 3, p. 133-150, set. 2001 (definição de imaginário nas p. 133-134).
} 
do vilão, examinemos rapidamente parte desse discurso antigo sobre a descrição, o qual nos sugere uma possibilidade de leitura do retrato em questão.

A Rhetorica ad Herennium, do século I a.C., um dos textos que, segundo Faral $^{314}$, mais foram recuperados pelas artes poéticas medievais, define a descrição nos seguintes termos: "La description consiste à narrer un fait de telle manière que l'action semble se dérouler et l'événement se passer sous nos yeux"315.

Essa ideia de visualização aparece também no terceiro capítulo do oitavo livro de $D e$ Institutione Oratoria, de Quintiliano ${ }^{316}$. Nele, o retor latino do século I d.C. trata da elegância, que implicaria, em primeiro lugar, a boa concepção e a expressão adequada do que se pretende dizer e, apenas depois, o brilho, a beleza. A clareza produz tal efeito que os ouvintes creem ver aquilo que se lhes narra, aumentando assim as chances de sucesso do discurso, que visa, como sabemos, a agir sobre o outro.

Quintiliano menciona um procedimento que consiste em pintar com as palavras um quadro de uma dada cena. Embora ele não o nomeie, fica evidente tratar-se do que chamamos de descrição. ${ }^{317} \mathrm{O}$ autor maravilha-se com o poder das brilhantes descrições de Cícero: fazer com que a imagem produzida na mente de seus ouvintes seja tão verdadeira que estes não possam dizer que a teriam visto melhor com seus próprios olhos. Não devemos, no entanto, pensar que se trate da transmissão de uma imagem precisa, tal qual vista por alguém, a uma terceira pessoa que não a viu, pois, na sequência, Quintiliano acrescenta :

Peut-on avoir assez peu d'imagination, pour ne pas lire le passage suivant des Verrines: "Debout sur le rivage, on vit un préteur du peuple romain, chaussé de sandales, en pallium de pourpre et en tunique traînante, appuyé sur une courtisane", sans se représenter le cadre et les attitudes, et même sans y ajouter quelques-uns des détails qui ne sont pas indiqués? Moi, du moins, je crois voir les traits, les regards et les caresses infâmes du couple, la muette réprobation des assistants et leur embarras craintif. ${ }^{318}$

\footnotetext{
${ }^{314}$ FARAL, E. Les arts poétiques du XII et du XIII siècle. Genève: Slatkine, 1982. p. 99.

315 RHÉTORIQUE à Hérennius. Paris: Les Belles Lettres, 1989. p. 224: “A descrição consiste em narrar um fato de tal maneira que a ação pareça se desenrolar e o evento se passar sob nossos olhos". (grifo meu)

316 "Embora não haja notícias de que a obra tenha sido diretamente conhecida na Idade Média, são constantes as referências subliminares a ela até sua revitalização a partir do Quatrocentos, quando passou a ser considerada protótipo do humanismo formalista". (MONGELLI, L. M.; VIEIRA, Y. F. A estética medieval. Cotia (SP): Íbis, 2003. p. 23, grifo meu).

${ }^{317}$ QUINTILIEN. De institutione oratoria. Paris: Garnier, 1934. p. 183.

318 Ibid., p. 183: "Pode-se ter tão pouca imaginação, para não ler a seguinte passagem das Verrinas: 'Em pé sobre a margem, viu-se um pretor do povo romano, calçando sandálias, vestindo um pálio púrpura e uma longa túnica, apoiado sobre uma cortesã', sem representar para si mesmo o quadro e as atitudes, e mesmo sem acrescentar-lhe alguns dos detalhes que não são indicados? Eu, ao menos, creio ver os traços, os olhares e as carícias infames do casal, a muda reprovação dos observadores e seu constrangimento temeroso". (grifos em negrito meus).
} 
Não se trata, portanto, da visão de algo, mas da produção de uma imagem mental a partir de um discurso. E se este, pela clareza de sua expressão, oferece elementos para a produção da imagem, esta se efetiva realmente por uma operação intelectual dos ouvintes, que podem inclusive acrescentar à cena detalhes não explicitamente descritos.

Esse acréscimo por parte do público não significa que o descritor possa descuidar das minúcias, pois, às vezes, segundo Quintiliano, a pintura de uma cena é realizada justamente pelo acúmulo de detalhes, procedimento que, na descrição da tomada de uma cidade, por exemplo, aumentaria a piedade por parte do público:

\begin{abstract}
Sans doute, quand on dit qu'une cité a été enlevée d'assaut, on embrasse sous ce mot tout ce que comporte un pareil sort; mais les sentiments sont moins touchés par ce que j'appellerai cette brève annonce d'une nouvelle. Si l'on développe ce qui est contenu dans un seul mot, on verra les flammes qui rampent parmi les maisons et les temples, le fracas des toits qui s'écroulent, des cris divers se fondant comme en un seul son, certains habitants fuyant à l'aventure, d'autres ne pouvant s'arracher aux derniers embrassements de leur famille, les pleurs des petits enfants et des femmes, des vieillards maudissant le destin qui a prolongé leur vie jusque-là; ensuite le pillage bien connu des objets profanes et sacrés, les soldats courant en tout sens pour emporter leur butin ou courir après, des citoyens, enchaînés, poussés devant lui par le brigand devenu leur maître, la mère s'efforçant de retenir son petit enfant, et, partout où le gain est plus considérable, les vainqueurs se battant. Tout cela, comme je l'ai dit, est renfermé dans le mot: "Sac d'une ville"; cependant, on dit moins en énonçant l'ensemble que tous les détails. ${ }^{319}$
\end{abstract}

Percebe-se que essa "pintura" — que consiste em desenvolver o conteúdo de uma só palavra ou expressão - não visa a reproduzir o real, mas a surtir um efeito, a comover.

Pensando naquilo que "torna mais viva a pintura das coisas", Quintiliano destaca o papel da comparação, chamando-a "maravilhosa invenção". ${ }^{320}$ Mas como o que o preocupa é a clareza do discurso e não questões de poética, afirma: "Ici il faut avant tout prendre garde

\footnotetext{
${ }^{319}$ QUINTILIEN. De institutione oratoria. Paris: Garnier, 1934. p. 183-185: “Sem dúvida, quando dizemos que uma cidade foi tomada de assalto, abarcamos sob essa palavra tudo o que comporta semelhante sorte, mas os sentimentos são menos tocados pelo que eu chamaria esse breve anúncio de uma informação. Se desenvolvermos o que está contido numa só palavra, veremos as chamas que se alastram pelas casas e templos, o estrondo dos telhados que desabam, os gritos diversos fundindo-se como num único som, certos habitantes fugindo a esmo, outros não podendo se desvencilhar dos últimos abraços de suas famílias, os choros das criancinhas e das mulheres, dos velhos maldizendo o destino que prolongou suas vidas até então; em seguida, o saque bem conhecido dos objetos profanos e sagrados, os soldados correndo em todas as direções para levar seu butim ou perseguir, cidadãos, acorrentados, empurrados pelo ladrão que se tornou seu dono, a mãe esforçando-se para segurar seu filhinho, e, por toda parte onde o ganho é mais considerável, os vencedores lutando entre si. Tudo isso, como disse, está contido na palavra 'saque de uma cidade'. No entanto, dizemos menos enunciando o conjunto que todos os detalhes". (grifos meus)

${ }^{320}$ Ibid., p. 185.
} 
que le terme de comparaison ne soit ni obscur ni inconnu. En effet, ce que l'on choisit pour éclairer une chose doit jeter plus de lumière que la chose à éclairer"321.

Vejamos em que isso nos ajuda a apreciar o retrato do vilão ${ }^{322}$ :

Uns vileins, qui resanbloit Mor,

Leiz et hideus a desmesure,

Einsi tres leide criature

Qu'an ne porroit dire de boche

Assis s'estoit sor une çoche,

Une grant maçue en sa main.

Je m'aprochai vers le vilain,

Si vi qu'il ot grosse la teste

Plus que roncins ne autre beste,

Chevox mechiez et front pelé,

S'ot pres de deus espanz de lé

Oroilles mossues et granz

Autiex com a uns olifanz,

Les sorcix granz et le vis plat,

Ialz de çuete, et nes de chat,

Boche fandue come lous,

Danz de sengler aguz et rous,

Barbe rosse, grenons tortiz,

Et le manton aers au piz,

Longue eschine torte et boçue ;

Apoiez fu sor sa maçue,

Vestuz de robe si estrange

Qu'il n'i avoit ne lin ne lange,

Einz ot a son col atachiez

Deus cuirs de novel escorchiez,

Ou de deus tors ou de deus bués. ${ }^{323}$
Um vilão, que parecia um mouro,

Demasiadamente feio e medonho,

Criatura tão feia

Que não se poderia descrever,

Estava sentado sobre uma cepa,

Com uma grande maça na mão.

Aproximei-me do vilão

E vi que tinha a cabeça maior

Que a de um rocim ou outro animal,

Os cabelos desgrenhados e a testa calva,

Com cerca de dois palmos de largura,

As orelhas peludas e grandes

Como as de um elefante,

As sobrancelhas grandes e o rosto achatado,

Olhos de coruja e nariz de gato,

A boca fendida como a de um lobo,

Dentes de javali, afiados e alaranjados,

Uma barba ruiva, bigodes retorcidos,

E o queixo pegado ao peito,

A coluna longa, torta e corcunda.

Estava apoiado em sua maça,

Vestido com uma roupa muito estranha,

Nem de linho, nem de lã,

Tinha antes amarradas ao pescoço

Duas peles recém-extraídas

Ou de touros ou de bois.

Apesar de afirmar sua impossibilidade de descrever tamanha feiura, Calogrenant acaba fazendo-o, e com aparente riqueza de detalhes. No entanto, se observarmos mais atentamente, veremos que há muito de imprecisão nesse retrato. Podemos ter uma impressão de precisão, pois, afinal, o narrador nos fornece: a posição do vilão, o que carregava, o tamanho da cabeça, a aparência dos cabelos, a largura da testa, a aparência das orelhas, o tamanho das sobrancelhas, o formato do rosto, a aparência dos olhos, do nariz, da boca, dos dentes, da barba, dos bigodes, do queixo, das costas, o material de suas vestimentas e o modo de prendê-

\footnotetext{
${ }^{321}$ QUINTILIEN. De institutione oratoria. Paris: Garnier, 1934. p. 187: “Aqui é preciso, antes de tudo, tomar cuidado para que o termo de comparação não seja nem obscuro nem desconhecido. Com efeito, o que se escolhe para clarear uma coisa deve lançar mais luz que a coisa a clarear".

322 Reproduzo, para comodidade do leitor, o trecho relativo ao físico do vilão. Para o episódio completo, remeto às páginas $72-74$ deste trabalho.

${ }^{323}$ Versos 286-311.
} 
las. Quanto a isso, o retrato do vilão segue uma tendência das narrativas dos séculos XII e XIII, apontada por Faral:

La description du physique obéit à des lois strictes. Souvent précédée d'un éloge du soin donné par Dieu ou par Nature à la confection de sa créature, elle porte d'abord sur la physionomie, puis sur le corps, puis sur le vêtement; et dans chacune de ces parties, chaque trait a sa place prévue. C'est ainsi que, pour la physionomie, on examine dans l'ordre la chevelure, le front, les sourcils et l'intervalle qui les sépare, les yeux, les joues et leur teint, le nez, la bouche et les dents, le menton; pour le corps, le cou et la nuque, les épaules, les bras, les mains, la poitrine, la taille, le ventre [...], les jambes et les pieds. ${ }^{324}$

Segundo Faral, esse ordenamento não é teorizado pelos antigos, nem mesmo colocado sob forma de preceito pelos mestres dos séculos XII e XIII, mas estes, em seus textos, oferecem exemplos de retratos que seguem esse padrão. Eles se baseiam em autores tidos como clássicos e que passaram a servir-lhes como modelos. Assim, Geoffroy de Vinsauf, no início do século XIII, cita o retrato de Teodorico II, rei dos visigodos, realizado por Sidônio Apolinário no século V, como o melhor modelo do gênero.

Mencionei uma aparente precisão no retrato do guardador de touros. Diante do comentário de Faral, torna-se evidente que se trata de precisão relativa a um modelo discursivo, que Chrétien altera apenas ligeiramente.

Mas alguns termos mostram o caráter aproximativo dessa descrição: o guardador de touros não é um mouro; apenas lembra um. Ora, assim como hoje muitos de nós fabricamos representações bastante diferentes acerca do que seja um muçulmano, apesar do espaço ocupado na mídia pelo mundo islâmico em razão de guerras e conflitos, o público de Chrétien talvez também o fizesse. Afinal, apesar dos contatos entre Oriente e Ocidente, especialmente na Península Ibérica - largamente ocupada desde o século VIII — e a partir das Cruzadas, não podemos nos esquecer do bombardeio ideológico a que se submetiam os homens de então, não apenas por parte do discurso da Igreja, mas também por meio da própria poesia: lembremo-nos de que, na Canção de Rolando, os muçulmanos são descritos com aparência demoníaca. E se, ainda hoje, com o encurtamento das distâncias e com o elevadíssimo grau de desenvolvimento das comunicações, muitas vezes, representamos o Outro de forma bastante

\footnotetext{
${ }^{324}$ FARAL, E. Les arts poétiques du XII ${ }^{e}$ et du XIII siècle. Genève: Slatkine, 1982. p. 80: "A descrição do físico obedece a leis estritas. Frequentemente precedida de um elogio ao cuidado empregado por Deus ou por Natureza na confecção de sua criatura, ela trata primeiramente da fisionomia, em seguida, do corpo e, depois, das roupas; e, em cada uma dessas partes, cada traço tem seu lugar previsto. É assim que, para a fisionomia, examinam-se, na ordem, os cabelos, a testa, as sobrancelhas e o intervalo que as separa, os olhos, as bochechas e sua tez, o nariz, a boca e os dentes, o queixo; para o corpo, o pescoço e a nuca, os ombros, os braços, as mãos, o peito, a cintura, o ventre [...], as pernas e os pés".
} 
deturpada, não é descabido pensar que os homens da França medieval, ao ouvirem a referência "mouro", imaginassem criaturas bastante diferentes entre si.

Além disso, a testa do vilão tem cerca de dois palmos de largura. A medida é aproximada. Do mesmo modo, o narrador-personagem não consegue se decidir se as roupas do vilão são confeccionadas de pele de touros $o u$ de bois.

Finalmente, várias partes do rosto são apresentadas não através de uma descrição delas mesmas, mas de uma aproximação com partes de outros seres. Assim, suas orelhas, por exemplo, não são algo em si, mas algo como outra coisa. Das dezoito informações mencionadas acima, seis, ou seja, um terço, utilizam comparações animais. É interessante também observar que a descrição, em alguns momentos, torna-se mais obscura, em razão de algumas omissões. Assim, às vezes, os adjetivos estão presentes: a cabeça é grande como a de um cavalo (de carga), as orelhas peludas e grandes como as de um elefante, a boca é fendida como a de um lobo, os dentes afiados e alaranjados. Mas, em duas ocorrências, a associação com o animal se dá sem que se conheça sua motivação: olhos de coruja, nariz de gato. Sob que aspecto os olhos do vilão lembram os de uma coruja e seu nariz o de um gato? Pela forma? Pelo tamanho? Pela cor? Por suas capacidades (visão e olfato apurados, respectivamente)? Note-se também que os termos comparativos tais quais "mais que" e "como" desaparecem e são substituídos pela preposição "de": olhos de coruja, nariz de gato, dentes de javali. Ora, ele possui olhos como os da coruja ou, de fato, olhos de coruja?

A pergunta pode parecer absurda, mas não o é. Na perspectiva de certos historiadores, essa indagação se justificaria — bem como a presença de uma personagem com tais características numa narrativa - pelo fato de os homens do século XII acreditarem na existência de monstros. Jacques Le Goff defende a crença em seres compósitos como traço do imaginário do período. ${ }^{325}$ Já entre os estudiosos de literatura, Francis Dubost afirma que Chrétien não partilharia de certas crenças e manteria um distanciamento crítico com relação ao maravilhoso por meio da ironia. ${ }^{326}$ Mas será realmente necessário recorrer a um dado do real — as supostas (des)crenças do período - para se compreender essa personagem? Não seria suficiente pensarmos que, nesse gênero poético, é verossímil que uma personagem que não seja o herói apresente traços físicos monstruosos? Lembremo-nos também de que as criaturas compósitas povoam todo o universo ficcional, da Antiguidade a Kafka, passando por Flaubert: o grifo, a mantícora, as harpias, a quimera, para citar apenas alguns daqueles

\footnotetext{
${ }^{325}$ LE GOFF, J. Maravilhoso. In: ; SCHMITT, J.-C. (Coord.). Dicionário temático do Ocidente medieval. São Paulo: EDUSC, 2002. v. 2. p. 112 e 116

${ }^{326}$ DUBOST, F. Merveilleux et fantastique dans le Chevalier au Lion. In: DUFOURNET, J. (Org.). Le Chevalier au Lion: approches d'un chef-d'oeuvre. Paris: Champion, 1988. p. 70.
} 
lembrados por Borges em seu O livro dos seres imaginários. ${ }^{327}$ Assim, em vez de incorporar um dado de sua realidade — ou que muitos de seus contemporâneos acreditariam ser uma realidade - , ao compor essa personagem, Chrétien não estaria dialogando com outros discursos poéticos?

$\mathrm{Na}$ descrição do vilão, não há nenhum animal fabuloso. Todos os animais mencionados (o rocim, a coruja, o gato, o lobo, o javali) são, uns mais, outros menos, e de jeitos diferentes, próximos do homem, parecendo mais familiares. Pelo menos, eles existem na Europa. A única exceção é o elefante, animal que, segundo Robert Delort, "assombra a imaginação dos cristãos medievais" ${ }^{328}$. Ora, Calogrenant mencionara a dificuldade de descrever a incomensurável feiura do vilão. Mas ele se lança a essa empreitada. Entretanto, trata-se de algo extraordinário, algo nunca visto. Para descrevê-lo, não vê outra saída a não ser recorrer a seu universo de referências familiares. Assim, a comparação parece agir aqui como um facilitador, tanto da verbalização de Calogrenant, quanto da compreensão por parte de seus ouvintes. O cavaleiro pretende transmitir a seu auditório uma imagem — ainda que pálida diante do original - do horror contemplado. Parece lógico que, para realizar seu intento, seu discurso deva ser claro. As comparações, segundo Quintiliano, podem tornar mais vívida a imagem, desde que o comparante não seja obscuro.

Nesse sentido, pode parecer curioso que Chrétien, por meio de Calogrenant, tenha escolhido como termo de comparação justamente um animal exótico como o elefante, que Delort situa entre os "pouco ou mal conhecidos"329. Segundo a especialista em história da arte medieval Suzanne Braun, o simbolismo do elefante na Idade Média é pobre e inspirou pouco os artistas do período. Para ela, os autores medievais insistem sobretudo nas características físicas do animal - destacando-se seu tamanho, sua tromba e suas presas —, e é esse exotismo, mais que seu simbolismo, que justificaria a representação do elefante em edifícios religiosos. ${ }^{330} \mathrm{Se}$ os textos medievais destacavam a tromba e as presas do elefante, Chrétien, diferentemente, busca a orelha como termo de comparação! Ora, se se visa à clareza do discurso, seria preferível adotar como comparante um animal com o qual o público estivesse mais familiarizado. Não apenas isso não ocorre, como ainda se elege um aspecto que não parece, para aquele público, distintivo do elefante.

\footnotetext{
${ }^{327}$ BORGES, J. L. O livro dos seres imaginários. São Paulo: Companhia das Letras, 2007.

328 DELORT, R. Animais. In: LE GOFF, J.; SCHMITT, J.-C. (Coord.). Dicionário temático do Ocidente medieval. São Paulo: EDUSC, 2002. v. 1. p. 66.

${ }^{329}$ Ibid., p. 66.

${ }^{330}$ BRAUN, S. Le symbolisme du bestiaire médiéval sculpté. Dossier de l'art, Dijon, n. 103, déc. 2003-jan. 2004 , p. 71.
} 
O texto emprega o adjetivo "grandes" para caracterizar as orelhas do vilão. Logo nos vêm à mente as enormes orelhas dos elefantes. Mas será que, ao tentar recompor mentalmente o retrato do vilão, todos pensamos no mesmo elefante? O elefante indiano possui orelhas bem menores que as do elefante africano. Esse pode parecer um detalhe irrelevante e mesmo absurdo num trabalho sobre literatura, mas não o é. Ele chama a atenção para o fato de que nem todos recebem a obra do mesmo modo. Se nós, modernos, partindo do princípio de que conhecemos bem os elefantes, já temos pelo menos dois "modelos" de orelhas, que dizer do homem medieval, que, evidentemente, não via elefantes diariamente em seu canal a cabo destinado aos documentários sobre a fauna do planeta?

Duas fotografias de edifícios religiosos mostram como a representação escultural do animal transformou-se rapidamente da segunda metade do século XII para a primeira do século seguinte. Na igreja de Andlau, na Alsácia (cerca de 1165), vê-se um animal que só reconhecemos como elefante graças aos adereços (uma espécie de sela com uma "torre" destinada a transportar pessoas) e ao que podemos deduzir ser uma tromba. As presas são discretas e as orelhas, imperceptíveis. $\mathrm{O}$ animal é grande, mas não gordo, tendo as proporções aproximadas de um cavalo (figura 3). Já na catedral de Metz (primeira metade do século XIII), vemos um animal no qual reconhecemos imediatamente um elefante. Sua tromba é bem visível, embora curta, assim como sua presa. No entanto, isso não o impede de ter garras, como as de um felino, uma cauda mais longa que a de um elefante verdadeiro e com um chumaço na ponta, lembrando a cauda de um leão. E, o detalhe que mais nos interessa, sua orelha: ela é grande, mas... humana! (figura 4)

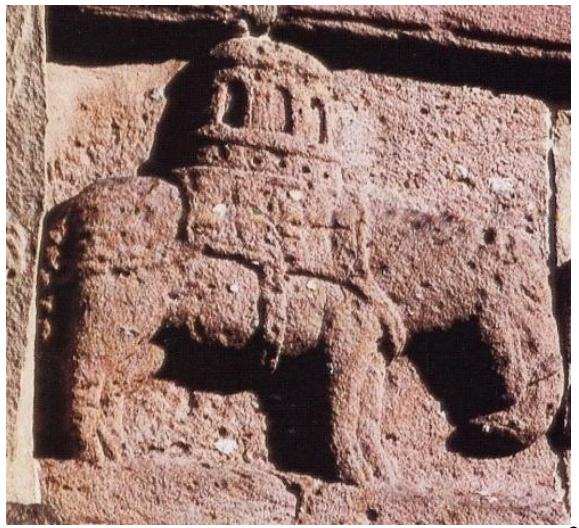

Figura 3 - Representação de elefante ${ }^{33}$ no painel da frisa exterior da igreja de Andlau, na Alsácia (c. 1165).

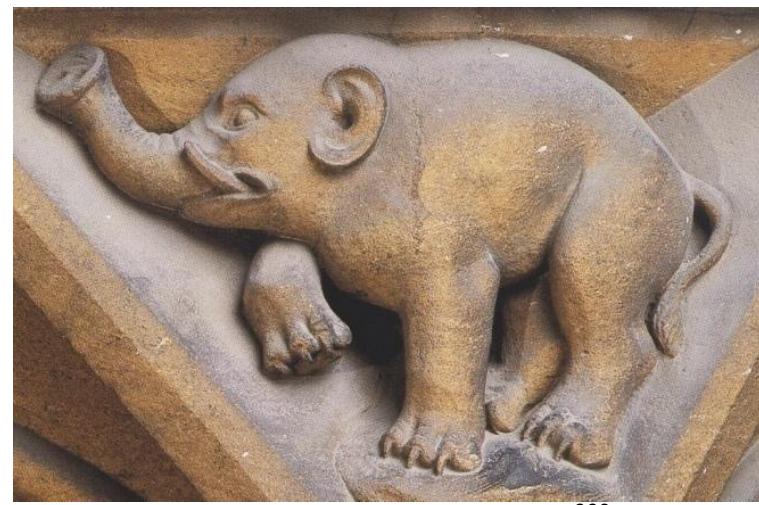

Figura 4 - Representação de elefante ${ }^{332}$ no portal de entrada da catedral de Metz (século XIII).

\footnotetext{
${ }^{331}$ BRAUN, S. Le symbolisme du bestiaire médiéval sculpté. Dossier de l'art, Dijon, n. 103, déc. 2003-jan. 2004, p. 70, detalhe de fotografia de Jacques Hampé.

${ }^{332}$ Ibid., p. 71, detalhe de fotografia de Jacques Hampé.
} 
Diante disso, que imagem das orelhas do vilão os ouvintes ou leitores do século XII fabricaram? Provavelmente um número tão grande de imagens quanto o de par de orelhas ou de olhos que ouviram ou leram essa história.

O mesmo se dá com a coruja. A referência "olhos de coruja" está longe de remeter a um só e mesmo objeto, como mostram duas outras fotografias. A primeira, da basílica de Saint Andoche de Saulieu (primeira metade do século XII), mostra uma representação de coruja muito próxima das nossas, mas sem "orelhas" e com olhos humanos: seu formato é de amêndoa e temos mesmo a impressão de que possui sobrancelhas! (figura 5) Já a ave que figura na catedral de Metz (primeira metade do século XIII) não seria imediatamente reconhecida por nós como uma coruja. Diferentemente de sua correspondente da basílica de Saint Andoche de Saulieu, ela possui orelhas, suas asas são proporcionalmente maiores e os olhos, detalhe que nos interessa, são redondos e sem pupilas, ou seja, dois círculos. (figura 6) Portanto, "olhos de coruja", "orelhas de elefante" e outras referências empregadas no retrato em questão são elementos que, mais que remeter a uma imagem precisa do real, estimulam a imaginação do público do século XII.

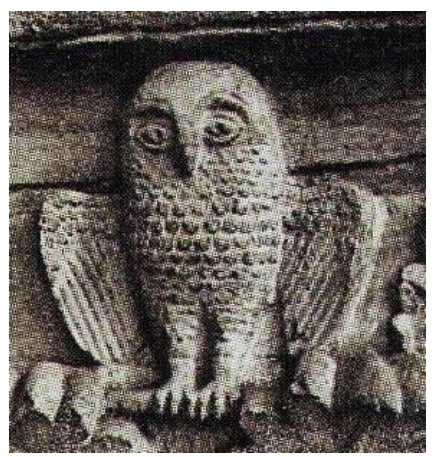

Figura 5 - Representação de coruja ${ }^{333}$ em capitel da basílica Saint Andoche de Saulieu (século XII).

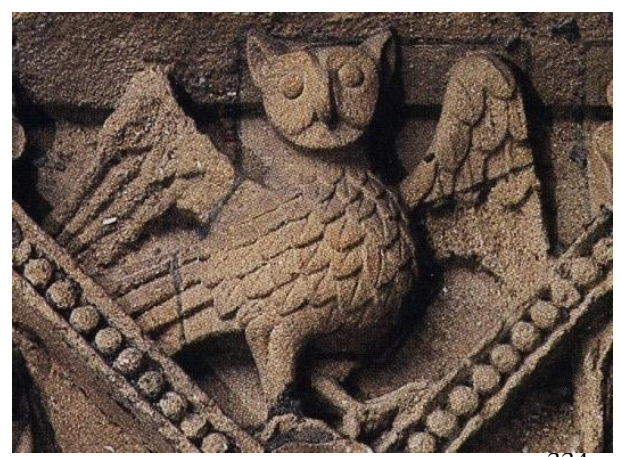

Figura 6 - Representação de coruja no portal norte da catedral de Metz (século XIII).

Vimos como a ideia dessa participação dos ouvintes na produção da imagem já aparecia em Quintiliano: a descrição tecnicamente bem construída convida o auditório a acrescentar-lhe detalhes mentalmente. Note-se, no entanto, que o público não cria ex nihilo uma imagem. Sua atividade intelectual consiste na resposta a um estímulo: a elocução perfeita do orador. Mas a preocupação do retor romano concentrava-se sobre a clareza de um discurso

\footnotetext{
${ }^{333}$ BRAUN, S. Le symbolisme du bestiaire médiéval sculpté. Dossier de l'art, Dijon, n. 103, déc. 2003-jan. 2004 , p. 62.

${ }^{334}$ Ibid., p. 62, detalhe de fotografia de Jacques Hampé.
} 
não poético. Assim, condenava comparações em que o comparante lançava mais trevas do que luz sobre o comparado.

O caso de Chrétien é diferente. Sendo poeta, sua técnica de construção da descrição segue outros princípios, como nos mostra Danièle James-Raoul, evocando Jean Frappier:

[...] "les énigmes, les ombres, les lacunes concertées du récit", que soulignait naguère J. Frappier, sont aussi à envisager chez cet auteur [Chrétien de Troyes] comme l'émanation d'un faisceau de procédés ou de figures "convergeant pour atténuer, dérégler ou entraver la clarté ou l'évidence du sens, mobilisant ainsi activement l'activité herméneutique de l'auditoire médiéval ou du lectorat moderne". 335

Portanto, se nos distanciarmos criticamente da narrativa e nos descolarmos do ponto de vista da personagem, a referência a um animal exótico como o elefante numa comparação ${ }^{336}$ que visaria a facilitar a transmissão da imagem precisa de um objeto deixa de parecer estranha. Trata-se de distinguir dois níveis de leitura: o da história e o do discurso. Assim, no primeiro, é a personagem que busca ser clara em sua descrição, recorrendo a comparações. Mas, por trás do segundo nível, temos o autor-modelo — voz fornecedora de instruções de leitura e manipuladora de uma estratégia narrativa ${ }^{337}$ —, que se esforça por sombrear a descrição, evitando toda luz difusa, de modo a inviabilizar qualquer possibilidade de apreensão imediata do objeto descrito, o que acaba agindo como estímulo para a imaginação, seja dos ouvintes das leituras em voz alta do século XII, seja dos leitores silenciosos de nosso tempo.

Assim, a descrição não consiste em pôr seu objeto sob os olhos do público, mas em produzir um discurso a partir do qual o leitor/ouvinte formará uma imagem. No entanto, não se trata da imagem do objeto, mas sim de uma certa imagem. Portanto, a descrição não reproduz; ela estimula uma produção. Ela consiste num conjunto de motivações imagéticas a partir das quais cada "receptor" pode construir sua própria imagem.

Vemos, portanto, que a questão é menos referencial que discursiva. Desse modo, o maravilhoso aparece não como a representação de um referente "empírico", no caso, as criaturas compósitas, nas quais os homens do século XII realmente acreditariam, segundo Le

\footnotetext{
335 JAMES-RAOUL, D. Chrétien de Troyes, la griffe d'un style. Paris: Honoré Champion, 2007. p. 107-108: “[...] 'os enigmas, as sombras, as lacunas premeditadas da narrativa', que sublinhara outrora J. Frappier, devem também ser vislumbradas nesse autor [Chrétien de Troyes] como a emanação de um feixe de procedimentos ou de figuras 'convergindo para atenuar, desregular ou entravar a clareza ou a evidência do sentido, mobilizando assim ativamente a atividade hermenêutica do auditório medieval ou dos leitores modernos"'. (grifo meu)

${ }^{336}$ Vimos com Adam que as comparações fazem parte do funcionamento do texto descritivo e com Hamon que elas — como outros tipos de predicados — relacionam-se à legibilidade e à previsibilidade do texto, tornando mais assimiláveis temas obscuros, ou, ao contrário, evitando a banalização de descrições altamente previsíveis.

${ }^{337}$ ECO, U. Seis passeios pelos bosques da ficção. São Paulo: Companhia das Letras, 2006. p. 21.
} 
Goff. Para nós, estudiosos da literatura, pouco importa em que acreditavam os homens do período. Ao aflorar na descrição, o maravilhoso aparece como fruto de uma operação discursiva, de um jogo escritural que repousa não apenas sobre a esfera da produção, mas também - e sobretudo - sobre a esfera da recepção do texto poético. Dito de outro modo: o vilão não é uma personagem maravilhosa porque é uma criatura compósita, ou porque exerce um domínio misterioso, talvez mágico, sobre os touros selvagens e, portanto, remete a um maravilhoso que poderia, segundo crenças do período, ser encontrado na vida real. Não são as características da personagem que nos permitem dizer que estamos diante de um elemento maravilhoso. O que permite afirmá-lo é a construção de um discurso, de tipo descritivo, que irrompe na narrativa trazendo à tona o incomum, o admirável, em sua textualidade, termo que, como lembra Zumthor, liberta-nos da falsa oposição entre forma e conteúdo. ${ }^{338}$ Enfim, a monstruosidade do vilão - bem como o maravilhamento dela decorrente - é fruto da poesia e não representação poética de um ser preexistente, ainda que imaginário.

Com Quintiliano, observamos que a descrição não visa a copiar com palavras uma realidade, mas a surtir um efeito: comover. Isso traria benefícios à causa a ser defendida. Em se tratando de poesia, visa-se também a um efeito, mas a um efeito diferente: deleitar e, no caso do retrato do vilão, eu diria maravilhar.

Esse maravilhamento é engendrado por uma estratégia discursiva - estudada por Philippe Hamon - cuja finalidade é evitar a platitude numa descrição potencialmente muito previsível, criando assim um efeito de poesia. Este e o maravilhamento caminham juntos, o que sugere a ideia de um "efeito de maravilhoso".

O modo pelo qual a crítica literária trata o maravilhoso - como soma de motivos definidos por sua íntima relação com o sobrenatural — demonstra que ela relega sua dimensão textual e poética, na melhor das hipóteses, para segundo plano. Parte-se de uma definição apriorística de maravilhoso como um conjunto de seres, objetos e fenômenos sobrenaturais e passa-se a buscar esses elementos nos textos, com objetivos variados, mas frequentemente muito mais próximos dos interesses de um historiador da cultura que de um estudioso do fenômeno poético. Assim, os recortes desse tipo de estudo do "maravilhoso" é geralmente temático — "As fadas na obra de X", "Os anéis mágicos em Y” —, raramente remetendo a uma prática escritural.

É tempo de redefinir o que chamamos de maravilhoso. Vimos que, para Daniel Poirion, ele é a “manifestation d'un écart culturel entre les valeurs de référence, servant à

\footnotetext{
${ }^{338}$ ZUMTHOR, P. Essai de poétique médiévale. Paris: Seuil, 2000. p. 32-33.
} 
établir la communication entre l'auteur et son plublic, et les qualités d'un monde autre ${ }^{, 339}$. Vimos também que, para Dubost, o motivo maravilhoso "se caractérise par la présence d'au moins un élément surnaturel dans la séquence minimale constituée par le couple thème/prédicat" ${ }^{, 340}$. Ora, essas definições excluem uma série de elementos que as próprias narrativas denominam "maravilhas"! No Roman de Thèbes, de cerca de 1150, considerado o primeiro romance da literatura francesa, o substantivo merveille e seus derivados aparecem caracterizando tanto um monstro com boca e nariz pretos, braços longuíssimos e orelhas capazes de cobrir todo o corpo, quanto os olhos de uma donzela, uma tapeçaria, um túmulo, uma tenda, entre outros objetos diante dos quais as personagens se maravilham.

O mesmo se dá em Yvain ou le Chevalier au Lion, no qual os termos mencionados designam, na maioria das vezes, o espanto das personagens ou do narrador diante de situações não sobrenaturais: o comportamento do rei, que se recolhe ao quarto com a rainha enquanto todos ainda estão reunidos; a duração da batalha entre Yvain e o defensor da fonte; o estado — pobre e nu - em que Yvain é encontrado desacordado na floresta por uma donzela; o fato de as vítimas de Harpin não terem — segundo acredita Yvain — procurado ajuda na corte de Arthur; a batalha entre Yvain e Gauvain; as palavras de Lunete ao anunciar a Yvain que ela conseguira arranjar sua reconciliação com Laudine. Os termos também aparecem em passagens de evidente caráter metafórico: para referir-se à separação entre o corpo de Yvain - que parte com Arthur e Gauvain - e seu coração - que permanece com Laudine; e no episódio em que os grandes amigos Yvain e Gauvain lutam sem se reconhecerem, no qual o narrador se pergunta como é possível Amor e Ódio ocuparem o mesmo corpo.

Portanto, "merveille" e derivados aparecem como sinônimos de "surpreendente", “inacreditável", "espantoso", "admirável” e não se referem necessariamente a elementos sobrenaturais.

Comentando Perceval ou le conte du Graal, Daniel Poirion afirma que, no início do poema, vemos o herói — ainda muito jovem e inexperiente — diante de uma falsa maravilha. ${ }^{341}$ Criado por sua mãe num lugar afastado, na ignorância até mesmo da existência da cavalaria, Perceval ao ouvir o barulho produzido por cinco cavaleiros pensa tratar-se de demônios. Mas, ao vê-los, é tomado por tão grande fascínio que julga tratar-se de anjos. Um

\footnotetext{
${ }^{339}$ POIRION, D. Le merveilleux dans la littérature française du Moyen Âge. $2^{\mathrm{e}}$ ed. Paris: P.U.F., 1995. p. 3-4: "manifestação de uma distância cultural entre os valores de referência, servindo a estabelecer a comunicação entre o autor e seu público, e as qualidades de um mundo outro".

${ }^{340}$ DUBOST, F. La vie paradoxale: la mort vivante et l'imaginaire fantastique au Moyen Âge. In: GINGRAS, F. (Dir.). Une étrange constance: les motifs merveilleux dans les littératures d'expression française du Moyen Âge à nos jours. Québec: Les Presses de l'Université Laval, 2006. p. 17: "caracteriza-se pela presença de ao menos um elemento sobrenatural na sequência mínima constituída pela dupla tema/predicado". (grifo meu)

${ }^{341}$ POIRION, op. cit., p. 77.
} 
deles destaca-se a tal ponto dos demais que o jovem acredita estar diante do próprio Deus. Trava-se um diálogo entre Perceval e esse cavaleiro, que se apresenta como tal. Mas não consegue obter do jovem extasiado a informação que deseja, pois, cada vez que repete a pergunta, recebe como resposta uma nova indagação: sobre sua lança, seu escudo, sua loriga, e inúmeros outros assuntos relativos à cavalaria.

O trecho é belíssimo e Poirion só vê nele uma falsa maravilha, pois, partindo de uma definição apriorística de maravilhoso, procura-o no lugar errado. O maravilhoso não está no referente "anjo", "demônio" ou "cavaleiro", mas no modo como são descritos. O maravilhamento de Perceval é absoluto diante de sua primeira visão de cavaleiros e o maravilhamento do leitor é total diante da arquitetura do texto, que — por meio da passagem de demônios a anjos e destes a cavaleiros, seguida por uma metonimização do cavaleiro promove uma série de descrições, as quais, longe de serem entediantes, são salpicadas de humor e repletas da beleza da descoberta.

Curiosamente, Poirion, que durante todos os capítulos de seu livro ocupara-se quase que exclusivamente de motivos, na conclusão, em que trata do teatro, reconhece o papel da escritura na produção de maravilhoso: "Par la lecture on communique non pas avec un monde féerique, mais avec le travail d'un écrivain. C'est ce travail qui définit le merveilleux" ${ }^{342}$. Apesar disso, ele não dá o passo definitivo e continua pensando o fenômeno do mesmo modo e chamando de "maravilhosos" os elementos que - mesmo frutos de um trabalho de escritura — possuem algum vínculo com o sobrenatural.

É assim que, num trecho que lembra muito a Poética de Aristóteles ${ }^{343}$, ele considera a representação teatral pouco favorável a um efeito de maravilhoso. O poder de sugestão da escritura é mais propício a esse efeito que a percepção de uma imagem que se recebe passivamente. "Les personnages féeriques eux-mêmes, incarnés par des personnes vivantes, costumées et fardées voire masquées, ne sont plus à la disposition de l'imagination du lecteur. Ils sont là, terriblement concrets et réalisés". ${ }^{344}$ Essas personagens, segundo o autor, podem mesmo acabar gerando o riso, o que fugiria de suas funções. Essas afirmações decorrem do

\footnotetext{
${ }^{342}$ POIRION, D. Le merveilleux dans la littérature française du Moyen Âge. $2^{\mathrm{e}}$ ed. Paris: P.U.F., 1995. p. 122: "Pela leitura, comunicamo-nos não com um mundo feérico, mas com o trabalho de um escritor. É esse trabalho que define o maravilhoso".

343 "O maravilhoso tem lugar primacial na tragédia; mas na epopeia, porque ante nossos olhos não agem atores, chega a ser admissível o irracional, de que muito especialmente deriva o maravilhoso. Em cena, ridícula resultaria a perseguição de Heitor [...]. Mas, na epopeia, tudo passa despercebido." (ARISTÓTELES. Poética. Tradução de Eudoro de Souza. $3^{\text {a }}$ ed. Lisboa: Imprensa Nacional - Casa da Moeda, 1992. p. 141, grifos meus)

${ }^{344}$ POIRION, op. cit., p. 122: "As próprias personagens feéricas, encarnadas por pessoas fantasiadas, maquiadas ou até mascaradas, não estão mais à disposição da imaginação do leitor. Elas estão aí, terrivelmente concretas e realizadas".
} 
fato de Poirion continuar considerando o maravilhoso como algo sobrenatural - aqui, feérico.

Mas Perceval foi brilhantemente posto em cena por Éric Rohmer, em 1978. O cineasta consegue nos maravilhar, mas não porque - graças a um aparato tecnológico e efeitos especiais de última geração - tenha conseguido criar a ilusão do sobrenatural. Ao contrário, tudo no filme é propositalmente falso: as árvores da floresta, os castelos, os figurinos, os objetos. E não se trata apenas do cenário. Em vez de prosificar e atualizar a linguagem para que o público se identificasse e, assim, mais facilmente se produzisse a impressão de realidade $^{345}$, Rohmer manteve a estrutura em versos e muitas expressões e pronúncias do francês antigo. O texto é adaptado, mas bastante fiel ao original.

Outro recurso que chama a atenção é o fato de que as personagens, além de pronunciarem suas próprias falas, pronunciam também as palavras do narrador sobre elas mesmas. Assim, por exemplo, vemos Brancaflor dizer, ao mesmo tempo em que executa a própria ação narrada: “- E a donzela [ela mesma] tomou-o carinhosamente pela mão...”. Na literatura e no cinema em geral, personagens podem assumir temporariamente a posição de narradores, mas não desse modo! Trata-se de um procedimento inusitado, raro.

Todos esses recursos impedem a produção da impressão de realidade; o espectador não se esquece, em momento algum, do fato de estar diante de um filme. Em vez de criar uma ilusão, esses elementos chamam a atenção do espectador sobre seu próprio artifício, ou seja, o cenário se mostra como cenário, as personagens como personagens, o texto como texto, enfim, o filme como filme, assim como o poema de Chrétien se mostra como poema. É a autorreferencialidade característica da poesia que Rohmer soube transpor para a linguagem cinematográfica. E é nisso que reside a atmosfera de maravilhoso do filme e não em seu "conteúdo".

O mesmo se dá com a poesia. Passagens como a do primeiro encontro de Perceval com cavaleiros - que não tem nada de sobrenatural — maravilham o público pela linguagem, ao passo que a descrição de um anel mágico que torna seu portador invisível pode passar despercebida e não nomear o objeto uma merveille.

Portanto, assim como Adam propõe não definirmos a descrição quanto a seu referente, proponho igualmente não definirmos o maravilhoso quanto a um suposto referente. Ao lermos o episódio do vilão, estamos diante de uma maravilha? Sim, mas não porque se trate de um tipo de personagem catalogado por uma tradição folclórica. Se o maravilhoso não está

\footnotetext{
345 Assim os cineastas denominam o fenômeno pelo qual mergulhamos na história a tal ponto que nos esquecemos tratar-se de um filme.
} 
no "conteúdo" - para utilizar a velha e tão difundida expressão —, ele não pode mais ser pensado em termos de motivos. O maravilhoso consiste num efeito. Esse efeito é provocado por um discurso de tipo descritivo, que não visa a reproduzir o real, mas a provocar um deleite. No entanto, esse deleite não deve ser entendido como o deslumbramento infantil diante de figuras folclóricas como a fada e o gigante. Ele é fruto de um árduo trabalho escritural, de um lado, e, de outro, de um trabalho intelectual de reescritura por parte do leitor, cuja participação ativa é solicitada na produção de um efeito de maravilhoso.

Daniel Poirion abre seu livro com o seguinte comentário: "Le Moyen Âge intellectuel est bien éclairé par la critique moderne. Mais plus d'un lecteur préfère encore, comme à l'époque romantique, le plaisir d'un plus naïf émerveillement que procure souvent la littérature médiévale" ${ }^{346}$. Ora, as reflexões realizadas neste trabalho a partir da leitura do retrato do vilão - e que apontaram, em vários momentos, para o caráter discursivo do maravilhoso - mostram que não há nada de ingênuo na poesia do século XII. Ela nos permitiu explorar questões relevantes para a teoria e a crítica literária contemporâneas, tais como: representação, níveis de leitura, produção e recepção do texto ficcional. Ela também nos possibilitou questionar a falsa oposição entre narrativo e descritivo e pensar as relações entre este e o maravilhoso. Ela nos permitiu, finalmente, reformular o próprio conceito de maravilhoso e, mais que isso, levou-nos a questionar nossa prática de adotar noções preestabelecidas, que, consciente ou inconscientemente, tendemos a projetar sobre os textos estudados.

A perspectiva de um maravilhoso como efeito de uma manipulação discursiva traz o benefício de retirá-lo do âmbito da crendice, da superstição, da curiosidade ingênua e mesmo do folclore, e de atribuir-lhe um lugar de importância nas reflexões atuais sobre o fazer poético.

\footnotetext{
${ }^{346}$ POIRION, D. Le merveilleux dans la littérature française du Moyen Âge. $2^{\mathrm{e}}$ ed. Paris: P.U.F., 1995. p. 3: “A Idade Média intelectual está bem iluminada pela crítica moderna. Mas mais de um leitor prefere ainda, como na época romântica, o prazer de um maravilhamento mais ingênuo, que fornece frequentemente a literatura medieval". (grifo meu)
} 


\section{DESDOBRAMENTOS}

Por que "desdobramentos" no lugar das tradicionais "conclusão" ou "considerações finais"? Porque não se trata de um fim, mas de um novo ponto de partida.

No universo arturiano, o retorno dos cavaleiros à Távola Redonda pode encerrar um texto, mas sugere um prolongamento da história. Os cavaleiros trocam suas experiências e o relato de cada um pode dar início a novas e diferentes aventuras. Assim, o percurso que transforma Yvain em Cavaleiro do Leão fora estimulado pela narrativa/descrição de uma aventura vivida por Calogrenant.

Aqui, trata-se também de um percurso. Movido por um interesse pelo maravilhoso, visto inicialmente como um conjunto de seres, objetos e fenômenos de caráter sobrenatural, passei a observá-lo numa narrativa em que tais elementos me pareciam abundantes. Tendo percebido uma relação entre eles e o procedimento descritivo, recortei um trecho no qual coexistiam e que me tocava especialmente, por seu aspecto inusitado e pela gratuidade assim pareceu-me num primeiro momento — de sua existência. Propus uma leitura inicial, que logo permitiu desfazer a primeira impressão e constatar que o retrato do vilão desempenha uma série de funções. Restava ainda investigar as relações entre maravilhoso e descrição. Assim, depois de uma incursão por diversos discursos que levam da descrição ao descritivo, pude retornar ao maravilhoso já com outro olhar, o que me levou a recusar certas abordagens.

Não pretendi esgotar aqui a bibliografia sobre o maravilhoso, nem mesmo sobre o descritivo. Não se tratava de chegar a uma resposta definitiva, mas, antes, à elaboração de uma questão, a ser desenvolvida no próximo nível da pesquisa. Para isso, a bibliografia consultada revelou-se suficiente. Assim, esse ponto de chegada - a construção de um lugar crítico a partir do qual passo a enxergar diferentemente a poesia — na verdade consiste num novo ponto de partida. Nesse sentido, proponho aqui não uma conclusão, mas desdobramentos possíveis. Passemos ao primeiro deles.

Vimos que o maravilhoso se relaciona intimamente com o descritivo. No plano da história, é ele quem justifica, em geral, a introdução de uma descrição. Descreve-se algo por seu caráter extraordinário, ou seja, a descrição é fruto da maravilha. No plano do discurso, ou seja, da estratégia narrativa do autor-modelo, a proposição se inverte. Não é uma maravilha preexistente que motiva a descrição, mas é esta que, por uma série de operações efetuadas 
tanto no nível da produção quanto no nível da recepção, impulsiona a eclosão do maravilhoso. A meta é o deleite, por via da maravilha, e esta passa pelo descritivo.

Mas nem toda descrição leva ao maravilhoso e o próprio Yvain ou le Chevalier au Lion é um exemplo disso. Vimos que algumas descrições de elementos corriqueiros da vida cotidiana provocam um efeito de real, podendo consistir, ao mesmo tempo, numa estratégia de criação de suspense. Diante disso, assim como Adam e Hamon se indagaram sobre a existência de uma especificidade do descritivo, não caberia estudar a possível existência de uma especificidade das descrições geradoras de um efeito de maravilhoso? Uma das formas de fazê-lo consiste em comparar descrições que provoquem esse efeito com outras que originem um efeito diferente, como o riso, por exemplo. Essa formulação já sugere uma pergunta: o maravilhoso exclui necessariamente o riso?

Outro desdobramento parte de indagações concernentes à própria essência do poético. Por um lado, podemos nos perguntar se o efeito de maravilhoso só existe na poesia. Por outro, podemos indagar se há poesia que não o gere. Hamon mostrou que a descrição - momento localizado do descritivo - é lugar de um efeito de poesia. Mas o descritivo - movimento global - não é apanágio do texto poético. Ele aparece, por exemplo, no discurso historiográfico. Quanto a este, os medievalistas já insistiram muito na presença de elementos maravilhosos - no sentido tradicionalmente adotado por eles — ao lado de "fatos verídicos" nas crônicas medievais. Assim, um estudo das crônicas - não à procura de motivos maravilhosos, mas em busca da possível existência de um efeito de maravilhoso provocado pelo descritivo - seria interessante, pois nos permitiria refletir sobre a própria natureza do ficcional, ao confrontá-lo com outros tipos de discurso.

Uma abordagem comparativa, levando-me para além dos domínios da poesia medieval, tampouco seria desprovida de interesse. Neste trabalho, propus uma reformulação da noção de maravilhoso, preferindo reservar esse termo para nomear um efeito e manter, para os motivos tradicionalmente associados à ideia de maravilha, o termo "sobrenatural". Para chegar a esse ponto, visitei os diferentes discursos pronunciados ao longo de séculos sobre a descrição. Vimos que, sobretudo na modernidade, ela foi mal vista por muitos leitores e escritores em razão de seu caráter digressório, por interromper a ação e estender-se em detalhes considerados inúteis. Constatamos, em seguida, a insustentabilidade dessa imagem negativa, primeiramente pelo artificialismo da oposição descritivo x narrativo. Além disso, nessa perspectiva depreciativa, a digressão é considerada um desvio em relação a algo tido como principal. Ora, em Yvain ou le Chevalier au Lion, não há um “principal” em relação ao qual as descrições possam ser digressórias, uma vez que o poema é essencialmente composto 
por uma sucessão de quadros narrativos/descritivos. Se os suprimirmos, o que restará? Assim, nesse poema de Chrétien, as descrições não se configuram como digressões.

Talvez essa estrutura seja muito característica de um tipo antigo de narrativa, anterior a um público que passou a perceber narração e descrição como radicalmente opostos. Mas é também verdade que, na modernidade, percebemos uma sobrevivência desse tipo de estrutura em romances como Antan d'enfance, de Patrick Chamoiseau, L'odeur du café e Pays sans chapeau, de Dany Laferrière, La gloire de mon père e Le château de ma mère, de Marcel Pagnol e, finalmente, em Grande Sertão: Veredas, de Guimarães Rosa. Assim, um estudo desses romances, atento ao descritivo, poderia verificar se, nessas narrativas modernas, ele também engendra o maravilhoso - já redefinido como fruto de uma composição discursiva e não como sobrenatural. E um estudo comparativo de uma narrativa antiga e de outra moderna permitiria identificar, na tríade descritivo-maravilhoso-poético, tendências gerais relevantes para a teoria literária como um todo - e suas realizações particulares — relevantes para o estudo de práticas escriturais específicas.

Nos limites deste trabalho, vimos o maravilhoso como efeito de uma manipulação discursiva associada a uma prática escritural. Como se daria o efeito de maravilhoso em narrativas orais? Quais as estratégias específicas para a obtenção desse efeito numa performance? Essa proposta é tanto mais estimulante quanto permite estabelecer uma relação entre a poesia dita medieval e uma prática contemporânea por meio de um traço que, segundo Zumthor, marcou profundamente a primeira: a oralidade.

Outro estudo possível, também extrapolando o universo da escritura, diz respeito ao cinema, já mencionado no último capítulo. Um recente desenho animado de Michel Ocelot Azur et Asmar —, ambientado na Idade Média, faz uso flagrante do descritivo, resultando também num efeito de maravilhoso. Elementos componentes do cenário - tendendo, portanto, a permanecer em segundo plano, como fundo para as ações dos heróis — são frequentemente trazidos para o primeiro plano, expulsando, algumas vezes, as personagens da tela: um jardim, com suas plantas, sua fonte, seus pássaros, músicos tocando, uma mesa farta, todos focalizados/descritos sucessivamente; um relógio; um labirinto d'água; uma cidade; um mercado, entre outros exemplos.

Além disso, procedimentos literários são utilizados no filme: em vez de simplesmente mostrar um objeto, acrescenta-se sua descrição verbal realizada por uma personagem, evitando-se assim o estatismo e a despersonalização da descrição; pelo mesmo motivo, descrevem-se ações; há preocupação com a motivação das descrições (close-ups nos olhos de Azur, cuja cor desempenhará um papel importante na sequência dos acontecimentos). 
Confrontar o descritivo verbal com o não verbal possui pelo menos dois interesses: por um lado, perceber como o poético alimenta outros discursos e, por outro, pelo contraste, apreender sua especificidade. Esse confronto poderia se dar pela análise dos recursos poéticos empregados pelo filme supracitado ou pela comparação entre os procedimentos descritivos de uma obra literária e aqueles de sua adaptação cinematográfica: Madame Bovary, Les liaisons dangereuses, Perceval, entre inúmeras outras.

Essas são apenas algumas das possibilidades de desdobramento do presente estudo. De qualquer forma, seja qual for o caminho percorrido daqui por diante, o fato é que este trabalho me levou, em vários momentos, a constatar a autorreferencialidade da poesia e o caráter discursivo do maravilhoso. Diante disso, torna-se inevitável iniciar um estudo aprofundado, por um lado, da Retórica antiga e, por outro, das modernas teorias do discurso.

Evidenciou-se aqui também o fato de meu interesse se distanciar cada vez mais de uma abordagem temática do ficcional. Em vez disso, ele recai sobre aspectos procedimentais e seus efeitos sobre o leitor. Assim, torna-se igualmente imperativo o estudo de teorias da escritura e da "recepção".

Há aqui provisões bastantes para uma nova e longa errância... 


\section{REFERÊNCIAS BIBLIOGRÁFICAS}

ACCARIE, M. La structure du Chevalier au Lion de Chrétien de Troyes. Le Moyen Âge, Paris, n. LXXXIV, p. 13-34, 1978.

ADAM, J-M.; PETITJEAN, A. Le texte descriptif. Paris: Nathan, 1989.

ADAM, J.-M. Une rhétorique de la description. In: MEYER, M.; LEMPEREUR, A. (Ed.). Figures et conflits rhétoriques. Bruxelles: Éditions de l’Université de Bruxelles, 1990. p. 168-192.

ADAM, J.-M. La description. Paris: P.U.F., 1993.

AINSWORTH, P. F. Conscience littéraire de l'histoire au Moyen Âge. In: LESTRINGANT, F.; ZINK, M. (Dir.). Histoire de la France littéraire. Paris: P.U.F., 2006. v. 1. p. 349-419.

ÁLVARES, C.; DIOGO, A. Laudine: entre fin Amors et Misogyne. Bien dire et bien aprandre, Lille, n. 11, p. 9-24, out. 1993. La description au Moyen Âge.

ARISTOTE. Rhétorique. Paris: Les Belles Lettres, 1991. 3 v.

ARISTÓTELES. Poética. Tradução de Eudoro de Souza. $3^{\mathrm{a}}$ ed. Lisboa: Imprensa Nacional Casa da Moeda, 1992.

AUCASSIN et Nicolette. Paris: Gallimard, 1999.

AUERBACH, E. Mimesis. $5^{\text {a }}$ ed. São Paulo: Perspectiva, 2007.

BANNIARD, M. Genèse de la langue française (III $\mathrm{I}^{\mathrm{e}} \mathrm{X}^{\mathrm{e}}$ siècles). In: LESTRINGANT, F.; ZINK, M. (Dir.). Histoire de la France littéraire. Paris: P.U.F., 2006. v. 1. p. 9-35.

BARIL, A. Manuel d'initiation à l'ancien français. Paris: Ellipses, 1998.

BARTHES, R. Essais critiques. Paris: Seuil, 1964.

BARTHES, R. L'effet de réel. In: Oeuvres complètes. Paris: Seuil, 2002. v. 3. p. 25-32. 
BASCHET, J. Diabo. In: LE GOFF, J.; SCHMITT, J.-C. (Coord.). Dicionário temático do Ocidente medieval. São Paulo: EDUSC, 2002. v. 1. p. 319-331.

BAUMGARTNER, E. La fontaine au pin. In: DUFOURNET, J. (Org.). Le Chevalier au Lion: approches d'un chef-d'oeuvre. Paris: Champion, 1988. p. 31-46.

BAUMGARTNER, E. Chrétien de Troyes: Yvain, Lancelot, la charrette et le lion. Paris: P.U.F., 1992.

BAZIN-TACCHELLA, S. Initiation à l'ancien français. Paris: Hachette, 2001.

BLONS-PIERRE, C. L'esthétique de la description des personnages chez Chrétien de Troyes. Bien dire et bien aprandre, Lille, n. 11, p. 55-68, out. 1993. La description au Moyen Âge.

BODENHEIMER, M.-O. La description du surnaturel dans Les miracles de Nostre Dame de Gautier de Coinci. Bien dire et bien aprandre, Lille, n. 11, p. 69-80, out. 1993. La description au Moyen Âge.

BORGES, J. L. O livro dos seres imaginários. São Paulo: Companhia das Letras, 2007.

BOUCHET, F. Le chevalier errant de Thomas de Saluces: lectures de la description et description de la lecture vers la fin du Moyen Âge. Bien dire et bien aprandre, Lille, n. 11, p. 81-104, out. 1993. La description au Moyen Âge.

BOUTET, D. La voix: mirages et présence de l'oralité au Moyen Âge. In: LESTRINGANT, F.; ZINK, M. (Dir.). Histoire de la France littéraire. Paris: P.U.F., 2006. v. 1. p. 193-212.

BRAIT, B. A personagem. $6^{\text {a }}$ ed. São Paulo: Ática, 1998.

BRAUN, S. Le symbolisme du bestiaire médiéval sculpté. Dossier de l'art, Dijon, n. 103, déc. 2003-jan. 2004.

CALVINO, I. Por que ler os clássicos. São Paulo: Companhia das Letras, 2000.

CANÇÃO dos Nibelungos (A). São Paulo: Martins Fontes, 2001. 
CARNÉ, D. de. Construction concurrentielle du personnage romanesque: trois exemples tirés du roman médiéval. In: CONNOCHIE-BOURGNE, C. (Org.). Façonner son personnage au Moyen Âge. Aix-en-Provence: P.U.P., 2007. p. 87-97.

CASTELLANI, M.-M. La description du héros masculin dans Érec et Énide de Chrétien de Troyes. Bien dire et bien aprandre, Lille, n. 11, p. 105-117, out. 1993. La description au Moyen Âge.

CHAMBEFORT, F. Le topos de l'indescriptible dans les portraits romanesques au XII ${ }^{\mathrm{e}}$ siècle. Bien dire et bien aprandre, Lille, n. 11, p. 119-129, out. 1993. La description au Moyen Âge.

CHANSON de Roland (La). Paris: Le Livre de Poche, 1990.

CHÂTELAINE de Vergy (La). Paris: Gallimard, 1994.

CHIAPPETTA, A. Retórica e crítica literária na Antiguidade. Phaos - Revista de Estudos Clássicos, Campinas (SP), n. 1, p. 39-60, 2001.

CHRÉTIEN DE TROYES. Romances da Távola Redonda. São Paulo: Martins Fontes, 1991.

CHRÉTIEN DE TROYES. Perceval ou o romance do Graal. São Paulo: Martins Fontes, 1992.

CHRÉTIEN DE TROYES. Oeuvres complètes. Paris: Gallimard, 1994. (Bibliothèque de la Pléiade).

CHRÉTIEN DE TROYES. Yvain ou le Chevalier au Lion. Paris: Flammarion, 1990.

CHRÉTIEN DE TROYES. Yvain ou le Chevalier au Lion. Paris: Gallimard, 2001.

CICÉRON. De l'invention. Paris: Les Belles Lettres, 1994.

COHEN, G. Un grand romancier d'amour et d'aventure au XII siècle: Chrétien de Troyes et son oeuvre. Paris: Boivins \& Cie., 1931.

COLÓQUIO INTERNACIONAL DE HISTÓRIA MEDIEVAL E CIÊNCIAS HUMANAS. "Por que estudar a Idade Média no século XXI?", 2008, São Paulo. Disponível em: <http://www.usp.br/leme/coloquio1.html>. Acesso em: 30 abr. 2008. 
COMBES, A. Comme un rêve de pierre: l'imaginaire de la sculpture dans le portrait médiéval. In: CONNOCHIE-BOURGNE, C. (Org.). Façonner son personnage au Moyen Âge. Aix-en-Provence: P.U.P., 2007. p. 123-134.

CURTIUS, E. R. Literatura europeia e Idade Média latina. São Paulo: Edusp, 1996.

DALLA VALLE, D. Le merveilleux et la vraisemblance dans la description des romans baroques: La promenade de Versailles de Madelaine de Scudéry. XVII siècle, Paris, n. 152, p. 223-230, juil.-sept. 1986.

DELCOURT, T. La littérature arthurienne. Paris: P.U.F., 2000.

DELORT, R. Animais. In: LE GOFF, J.; SCHMITT, J.-C. (Coord.). Dicionário temático do Ocidente medieval. São Paulo: EDUSC, 2002. v. 1. p. 57-67.

DIDIER, B. Commentaires. In: LACLOS, C. de. Les liaisons dangereuses. Paris: Le Livre de Poche, 1993. p. 535-584.

DUBOST, F. Merveilleux et fantastique dans Le Chevalier au Lion. In: DUFOURNET, J. (Org.). Le Chevalier au Lion: approches d'un chef-d'oeuvre. Paris: Champion, 1988. p. 47-76.

DUBOST, F. Aspects fantastiques de la littérature narrative médiévale (XII ${ }^{e}$ XIII ${ }^{e}$ siècles): L'Autre, l'Ailleurs, l'Autrefois. Paris: Honoré Champion, 1991.

DUBOST, F. La vie paradoxale: la mort vivante et l'imaginaire fantastique au Moyen Âge. In: GINGRAS, F. (Dir.). Une étrange constance: les motifs merveilleux dans les littératures d'expression française du Moyen Âge à nos jours. Québec: Les Presses de l'Université Laval, 2006. p. 11-38.

DUFOURNET, J. Le Lion d'Yvain. In: chef-d'oeuvre. Paris: Champion, 1988. p. 77-104. . (Org.). Le Chevalier au Lion: approches d'un

DUPONT, F. L’invention de la littérature. Paris: La Découverte, 1998.

EAGLETON, T. Teoria da literatura: uma introdução. $5^{\text {a }}$ ed. São Paulo: Martins Fontes, 2003.

ECO, U. Seis passeios pelos bosques da ficção. São Paulo: Companhia das Letras, 2006. 
ECO, U. (Org.). História da feiura. Rio de Janeiro: Record, 2007.

FARAL, E. Les arts poétiques du XII et du XIII siècle. Genève: Slatkine, 1982.

FERNANDES, R. M. R. Concepções e formas de imitar: um enquadramento para Dionísio de Halicarnasso. In: DIONÍSIO DE HALICARNASSO. Tratado da imitação. Lisboa: Instituto Nacional de Investigação Científica, 1986. p. 11-30.

FERREIRA, J. P. Paul Zumthor, profissão medievalista. Signum, São Paulo, n. 1, p. 185-205, 1999.

FRANCO JÚNIOR, H. Cocanha: a história de um país imaginário. São Paulo: Companhia das Letras, 1998.

FRAPPIER, J. Étude sur Yvain ou le Chevalier au Lion de Chrétien de Troyes. Paris: SEDES, 1969.

FREUD, S. L'inquiétante étrangeté et autres essais. Paris: Gallimard, 1985.

FRITZ, J.-M. Le roman en vers au Moyen Âge. In: LESTRINGANT, F.; ZINK, M. (Dir.). Histoire de la France littéraire. Paris: P.U.F., 2006. v. 1. p. 957-969.

GALAND-HALLYN, P. Art descriptif et argumentation dans la poésie latine. In : MEYER, M.; LEMPEREUR, A. (Ed.). Figures et conflits rhétoriques. Bruxelles: Éditions de l'Université de Bruxelles, 1990. p. 39-57.

GALDERISI, C. Conscience littéraire et émergence de l'individu au Moyen Âge. In: LESTRINGANT, F.; ZINK, M. (Dir.). Histoire de la France littéraire. Paris: P.U.F., 2006. v. 1. p. 667-677.

GALDERISI, C. Vers et prose au Moyen Âge. In: LESTRINGANT, F.; ZINK, M. (Dir.). Histoire de la France littéraire. Paris: P.U.F., 2006. v. 1. p. 745-766.

GALDERISI, C. La discontinuité des poétiques au Moyen Âge. In: LESTRINGANT, F.; ZINK, M. (Dir.). Histoire de la France littéraire. Paris: P.U.F., 2006. v. 1. p. 785-794.

GENETTE, G. Mots et merveilles. In: Figures. Paris: Seuil, 1966. p. 171-183. 
GENETTE, G. Frontières du récit. In: Figures II. Paris: Seuil, 1969. p. 49-69.

GERVAIS DE TILBURY. Le livre des merveilles. Paris: Les Belles Lettres, 2004.

GINGRAS, F. (Dir.). Une étrange constance: les motifs merveilleux dans les littératures d'expression française du Moyen Âge à nos jours. Québec: Les Presses de l'Université Laval, 2006.

GREENE, V. Qui croit au retour d'Arthur? Cahiers de civilisation médiévale, Paris, n. 45, p. 321-340, 2002.

GREIMAS, A. J. (Ed.). Dictionnaire de l'ancien français. Paris: Larousse, 2001.

HAMON, P. Pour un statut sémiologique du personnage. Littérature, Paris, n. 6, p. 86-110, mai 1972.

HAMON, P. Qu'est-ce qu'une description? Poétique, Paris, n. 12, p. 465-485, 1972.

HAMON, P. Du descriptif. Paris: Hachette, 1993.

HANSEN, J. A. Categorias epidíticas da ekphrasis. Revista USP, São Paulo, n. 71, p. 85-105, set. 2006.

HARF-LANCNER, L. Les fées au Moyen Âge. Paris: Honoré Champion, 1984.

HASENOHR, G. Le livre manuscrit. In: LESTRINGANT, F.; ZINK, M. (Dir.). Histoire de la France littéraire. Paris: P.U.F., 2006. v. 1. p. 151-173.

HÉROS et merveilles du Moyen Âge. Les collections de l'histoire. Paris: Société d'Éditions Scientifiques, n. 36, juil.-sept. 2007.

HORACE. Art poétique. In: Épitres. Paris: Les Belles Lettres, 1995. p.179-226.

JAMES-RAOUL, D. L'anonymat définitif des personnages et l'avènement du roman: l'apport de Chrétien de Troyes. In: CONNOCHIE-BOURGNE, C. (Org.). Façonner son personnage au Moyen Âge. Aix-en-Provence: P.U.P., 2007. p. 135-144. 
JAMES-RAOUL, D. Chrétien de Troyes, la griffe d'un style. Paris: Honoré Champion, 2007.

JAMES-RAOUL, D. L'oeuvre littéraire médiévale comme forme-sens: Depoimento [mar. 2005]. Entrevistador: Richard Fillon. Paris: Maison des Sciences de l'Homme. Disponível em: <http://www.archivesaudiovisuelles.fr/421/introduction.asp?id=421>. Acesso em: 2 maio 2008.

JAUSS, H.-R. Littérature médiévale et théorie des genres. Poétique, Paris, n. 1, p. 79-101, 1970.

JAUSS, H.-R. Littérature médiévale et expérience esthétique. Poétique, Paris, n. 31, p. 322336, sept. 1977.

JAUSS, H.-R. La jouissance esthétique: les expériences fondamentales de la poiesis, de l'aisthesis et de la catharsis. Poétique, Paris, n. 39, p. 261-274, sept. 1979.

JEAN D’ARRAS. Mélusine ou la noble histoire de Lusignan. Paris: Le Livre de Poche, 2003.

JENNY, L. La description. I. 1. De l'ekphrasis à la description réaliste. In: Méthodes et problèmes, 2004, Genève. Disponível em : <http://www.unige.ch/lettres/framo/enseignements/methodes/description/>. Acesso em: 15 set. 2008.

JOLY, G. L'ancien français. Paris: Belin, 2004.

JOUVE, V. L'effet-personnage dans le roman. $2^{\mathrm{e}}$ ed. Paris: P.U.F., 2008.

KELLY, D. Le jeu de la vérité. In: DUFOURNET, J. (Org.). Le Chevalier au Lion: approches d'un chef-d'oeuvre. Paris: Champion, 1988. p. 105-117.

KIBEDI-VARGA, A. Une rhétorique aléatoire: agir par l'image. In: MEYER, M.; LEMPEREUR, A. (Ed.). Figures et conflits rhétoriques. Bruxelles: Éditions de l'Université de Bruxelles, 1990. p. 193-200.

KOBLE, N.; SÉGUY, M. Introduction: "L'audace d'être médiéviste”. Littérature, Paris, n. 148, p. 3-9, déc. 2007. Le Moyen Âge Contemporain: perspectives critiques.

LAIS féeriques des XII ${ }^{\mathrm{e}}$ et XIII ${ }^{\mathrm{e}}$ siècles. Paris: Flammarion, 1992.

LAUSBERG, H. Elementos de retórica literária. Lisboa: Fundação Calouste Gulbenkian, [1966]. 
LECOUTEUX, C. Harpin de la Montagne. Cahiers de civilisation médiévale, Poitiers, n. 30, p. 219-225, 1987.

LE GOFF, J. O maravilhoso e o quotidiano no Ocidente medieval. Lisboa: Edições 70, 1990.

LE GOFF, J. Maravilhoso. In: ; SCHMITT, J.-C. Dicionário temático do Ocidente medieval. São Paulo: EDUSC, 2002. v. 2. p. 105-120.

LE GOFF, J. Héros et merveilles du Moyen Âge. Paris: Seuil, 2005.

LUCKEN, C. Le Moyen Âge ou la Fin des Temps. Avenirs d'un refoulé. Littérature, Paris, n. 130, p. 8-25, juin 2003. Altérités du Moyen Âge.

MARACHE, B. Le mot et la notion d'aventure dans la "conjointure" et le "sen" du Chevalier au Lion. In: DUFOURNET, J. (Org.). Le Chevalier au Lion: approches d'un chef-d'oeuvre. Paris: Champion, 1988. p. 119-138.

MARIE DE FRANCE. Le lai de Lanval. Paris: Le Livre de Poche, 1995.

MARIE DE FRANCE. Lais. Paris: Gallimard, 2002.

MÉNARD, P. Rires et sourires dans le roman du Chevalier au Lion. In: DUFOURNET, J. (Org.). Le Chevalier au Lion: approches d'un chef-d'oeuvre. Paris: Champion, 1988. p. 7-29.

MEYER, M. Questions de rhétorique: langage, raison et séduction. Paris: Le Livre de Poche, 1993.

MIRAUX, J.-P. Le portrait littéraire. Paris: Hachette, 2003.

MOLINIÉ, G. Dictionnaire de rhétorique. Paris: Le Livre de Poche, 1992.

MONGELLI, L. M.; VIEIRA, Y. F. A estética medieval. Cotia (SP): Íbis, 2003.

MORA, F. Leçons d'infidélité: le rapport aux lettres antiques et la création de nouveaux modèles. Le domaine français. In: LESTRINGANT, F.; ZINK, M. (Dir.). Histoire de la France littéraire. Paris: P.U.F., 2006. v. 1. p. 702-714. 
MOSCA, L. do L. S. (Org.). Retóricas de ontem e de hoje. $2^{\text {a }}$ ed. São Paulo: Humanitas, 2001.

MUHANA, A. A epopeia em prosa seiscentista. São Paulo: UNESP, 1997.

NYKROG, P. Chrétien de Troyes: romancier discutable. Genève: Droz, 1996.

PASTOUREAU, M. No tempo dos cavaleiros da Távola Redonda. São Paulo: Companhia das Letras, 1989.

PASTRÉ, J.-M. L'héroïne et son portrait: l'art de la description dans la littérature médiévale allemande. Bien dire et bien aprandre, Lille, n. 11, p. 289-302, out. 1993. La description au Moyen Âge.

PAYEN, J.-C. Chrétien de Troyes. In: BEAUMARCHAIS, J.-P. de; COUTY, D.; REY, A. Dictionnaire des littératures de langue française. Paris: Bordas, 1984. v. 1. p. 453-460.

PENNAC, D. Comme un roman. Paris: Gallimard, 1992.

PENNAC, D. Como um romance. Tradução de Leny Werneck. Rio de Janeiro: Rocco, 1993.

PETIT, A. Les premières descriptions de tentes: la tente d'Adrastus dans le Roman de Thèbes. Bien dire et bien aprandre, Lille, n. 11, p. 303-315, out. 1993. La description au Moyen Âge.

POIRION, D. Le merveilleux dans la littérature française du Moyen Âge. $2^{\mathrm{e}}$ ed. Paris: P.U.F., 1995.

POUGEOISE, M. Dictionnaire de rhétorique. Paris: Armand Colin, 2004.

QU'EST-CE QU'UN AUTEUR?: COURS D'ANTOINE COMPAGNON, [20-?], Paris. Disponível em: < http://www.fabula.org/compagnon/auteur2.php>. Acesso em: 30 abr. 2008.

QUINTILIEN. De institutione oratoria. Paris: Garnier, 1934.

RHÉTORIQUE à Hérennius. Paris: Les Belles Lettres, 1989. 
RIBARD, J. Yvain et Gauvain dans Le Chevalier au Lion. Essai d'interprétation symbolique. In: DUFOURNET, J. (Org.). Le Chevalier au Lion: approches d'un chef-d'oeuvre. Paris: Champion, 1988. p. 139-152.

ROBERT DE BORON. Merlin. Paris: Flammarion, 1994.

ROHOU, J. L'histoire littéraire. Paris: Nathan, 1996.

ROMAN de Thèbes (Le). Paris: Le Livre de Poche, 1995.

ROUSSE, M. Introduction. In: CHRÉTIEN DE TROYES. Yvain ou le Chevalier au Lion. Paris: Flammarion, 1990. p. 9-37.

SANTUCCI, M. La folie dans Le Chevalier au Lion. In: DUFOURNET, J. (Org.). Le Chevalier au Lion: approches d'un chef-d'oeuvre. Paris: Champion, 1988. p. 153-172.

SCHMITT, J.-C. A imaginação eficaz. Signum, São Paulo, n. 3, p. 133-150, set. 2001.

SIDOINE APOLLINAIRE. Correspondance. Paris: Les Belles Letres, 2003. v. 2: Livres I-V.

SOUZA, L. M. A feitiçaria na Europa moderna. São Paulo: Ática, 1987.

STANESCO, M.; ZINK, M. Histoire européenne du roman médiéval. Paris: P.U.F., 1992.

STANESCO, M. D'armes et d'amour. Orléans: Paradigme, 2002.

STANESCO, M. L'espace linguistique européen: le Moyen Âge. In: LESTRINGANT, F.; ZINK, M. (Dir.). Histoire de la France littéraire. Paris: P.U.F., 2006. v. 1. p. 78-96.

STANESCO, M. Les romans en prose au Moyen Âge. In: LESTRINGANT, F.; ZINK, M. (Dir.). Histoire de la France littéraire. Paris: P.U.F., 2006. v. 1. p. 970-983.

STRUBEL, A. Le sens de l'écriture et le déchiffrement du monde: le Moyen Âge. In: LESTRINGANT, F.; ZINK, M. (Dir.). Histoire de la France littéraire. Paris: P.U.F., 2006. v. 1. p. 237-262. 
STRUBEL, A. Lisible/visible. Ekphrasis et allégorie au Moyen Âge. In: LESTRINGANT, F.; ZINK, M. (Dir.). Histoire de la France littéraire. Paris: P.U.F., 2006. v. 1. p. 291-314.

SUARD, F. La description dans la chanson de geste. Bien dire et bien aprandre, Lille, n. 11, p. 401-417, out. 1993. La description au Moyen Âge.

SUBRENAT, J. Pourquoi Yvain et son lion ont-ils affronté les fils de Nétun? In: DUFOURNET, J. (Org.). Le Chevalier au Lion: approches d'un chef-d'oeuvre. Paris: Champion, 1988. p. 173-193.

THOMASSET, C.; UELTSCHI, K. Pour lire l'ancien français. Paris: Armand Colin, 2004.

TILLIETTE, J.-Y. La descriptio Helenae dans la poésie latine du XII ${ }^{\mathrm{e}}$ siècle. Bien dire et bien aprandre, Lille, n. 11, p. 419-432, out. 1993. La description au Moyen Âge.

TILLIETTE, J.-Y. Leçons d'infidélité: le rapport aux lettres antiques et la création de nouveaux modèles. Le Moyen Âge latin. In: LESTRINGANT, F.; ZINK, M. (Dir.). Histoire de la France littéraire. Paris: P.U.F., 2006. v. 1. p. 691-702.

TODOROV, T. Introdução à literatura fantástica. $3^{\text {a }}$ ed. São Paulo: Perspectiva, 2008.

TRACHSLER, R. Un siècle de lettreüre. Observations sur les études de littérature française du Moyen Âge entre 1900 et 2000. Cahiers de civilisation médiévale, Poitiers, n. 48, p. 359$380,2005$.

TRISTAN et Iseut: les poèmes français, la saga norroise. Paris: Le Livre de Poche, 1989.

VALETTE, J.-R. Pour une poétique du personnage merveilleux: la fabrique de fées. In: CONNOCHIE-BOURGNE, C. (Org.). Façonner son personnage au Moyen Âge. Aix-enProvence: P.U.P., 2007. p. 339-349.

VOISSET, G. M. Ici, ailleurs, au-delà: topographie du réel et de l'irréel dans "Le Chevalier au Lion”. Senefiance, Aix-en-Provence, n. VII, p. 703-715, 1979.

WALTER, P. Temps romanesque et temps mythique: éléments pour une recherche. In: DUFOURNET, J. Le Chevalier au Lion: approches d'un chef-d'oeuvre. Paris: Champion, 1988. p. 195-217. 
WALTER, P. Canicule: essai de mythologie sur Yvain de Chrétien de Troyes. Paris: SEDES, 1988.

WALTER, P. Chrétien de Troyes. Paris: P.U.F., 1997.

ZINK, M. Trente ans avec la littérature médiévale. Note brève sur de longues années. Cahiers de civilisation médiévale, Poitiers, n. 39, p. 27-40, 1996.

ZINK, M. Literatura(s). In: LE GOFF, J.; SCHMITT, J.-C. (Coord.). Dicionário temático do Ocidente medieval. São Paulo: EDUSC, 2002. v. 2. p. 79-93.

ZUMTHOR, P. Histoire littéraire de la France médiévale. Paris: P.U.F., 1954.

ZUMTHOR, P. Essai de poétique médiévale. Paris: Seuil, 2000.

ZUMTHOR, P. Parler du Moyen Âge. Paris: Éditions de Minuit, 1980.

ZUMTHOR, P. Introduction à la poésie orale. Paris: Seuil, 1983.

ZUMTHOR, P. Y a-t-il une "littérature” médiévale? Poétique, Paris, n. 66, p. 131-139, 1986.

ZUMTHOR, P. A letra e a voz: a "literatura" medieval. São Paulo: Companhia das Letras, 1993.

ZUMTHOR, P. La mesure du monde. Paris: Seuil, 1993. 